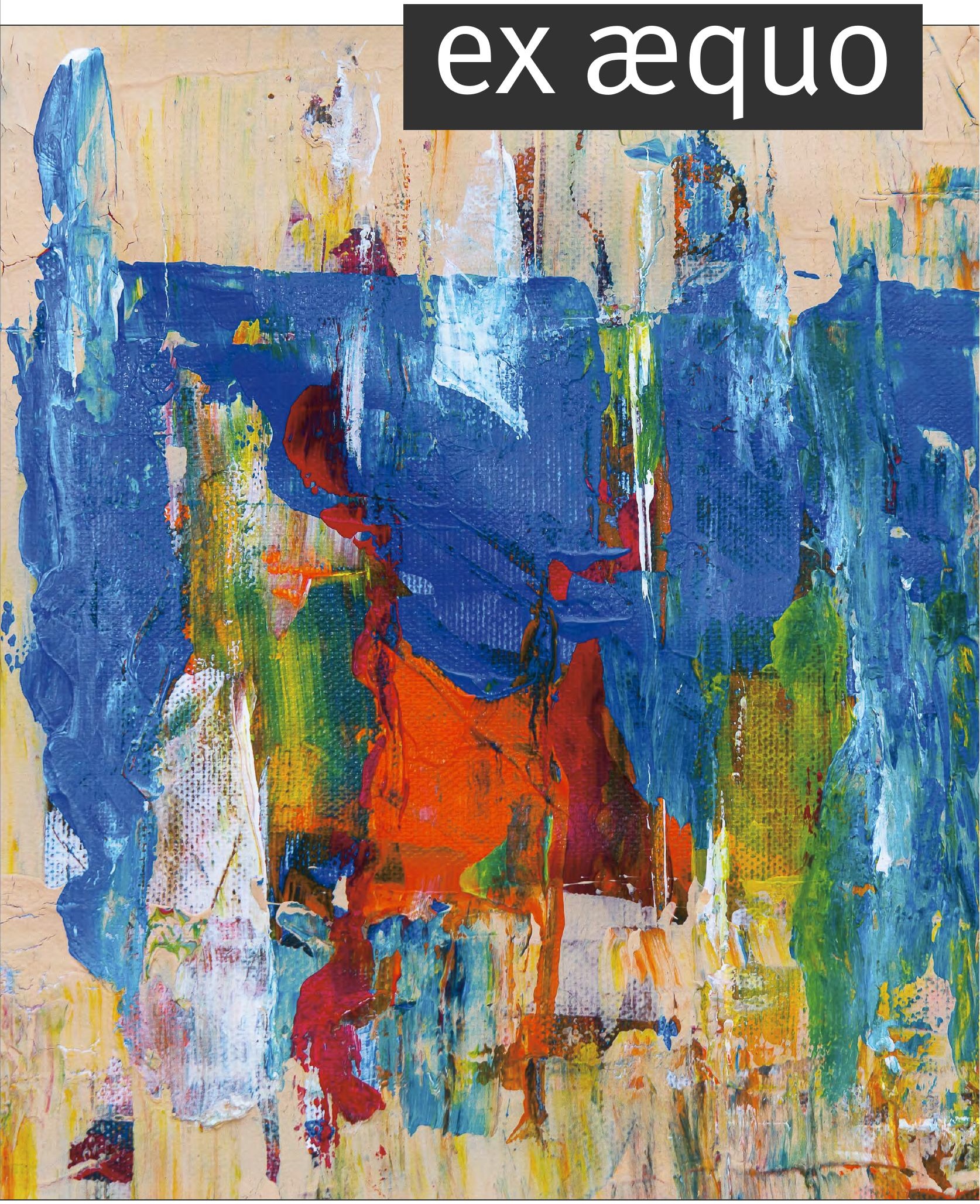





\section{ex æquo}

Revista semestral $\bullet \mathrm{N}^{\mathrm{o}} 42,2020 \bullet$ preço: $15 €$

Revista da Associação Portuguesa de Estudos sobre as Mulheres - APEM

Edição cofinanciada através de um projeto de Campanhas de Sensibilização na Área da Cidadania e Igualdade de Género promovido pela CIG com apoio do Fundo Social Europeu, no âmbito do Programa Operacional Inclusão Social e Emprego (POISE), tipologia 3.14. 
ex æquo - Revista da Associação Portuguesa de Estudos sobre as Mulheres

Revista semestral • N. ${ }^{\circ} 42,2020$

\section{Diretora}

Virgínia Ferreira - Faculdade de Economia da Universidade de Coimbra

\section{Diretoras Associadas}

Cristina C. Vieira - Faculdade de Psicologia e Ciências da Educação, Universidade de Coimbra

Maria João Silveirinha - Faculdade de Letras da Universidade de Coimbra

Cláudia Álvares - Instituto Universitário de Lisboa - ISCTE-IUL

Lina Coelho - Faculdade de Economia da Universidade de Coimbra

Sara Isabel Magalhães - Centro de Psicologia da Universidade do Porto

Diretoras de Secções

Cristina C. Vieira - Recensões; Maria João Silveirinha - Estudos e Ensaios

Diretoras Anteriores

Virgínia Ferreira (1999-2003); Helena Costa Araújo (2003-2007); Teresa Pinto (2007-2014)

Revisão: Victor Ferreira, Virgínia Ferreira, Teresa Mourinho Tavares

Coordenação do Dossier: Maria João Silveirinha, Faculdade de Letras, Univ Coimbra e Centro de Investigação do Instituto da Comunicação da Univ Nova de Lisboa; Cláudia Álvares, Departamento de Sociologia do ISCTE-Instituto Universitário de Lisboa; Centro de Investigação e Estudos de Sociologia (CIES)

Propriedade do Título: Associação Portuguesa de Estudos sobre as Mulheres - APEM

NIPC: 502914513

N. ${ }^{\circ}$ Registo no ex-ICS, atual ERC - Entidade Reguladora para a Comunicação Social: 123506

ISSN: 0874-5560; ISSN eletrónico: 2184-0385

Depósito Legal: 136336/99

Sede da Redação: Centro Maria Alzira Lemos - Casa das Associações, Parque Infantil do Alvito, Estrada do Alvito, 1300-054 Lisboa

Telefone: 962730527 E-mail: apem1991@gmail.com URL: http://exaequo.apem-estudos.org/ Edição/Impressão: Edições Afrontamento; Impressão e acabamento: Rainho \& Neves, Lda./ Santa Maria da Feira/Portugal

N. ${ }^{\circ}$ de edição: 2056

Edição/Impressão: Rainho \& Neves, Lda./Santa Maria da Feira/Portugal

Capa: Departamento Gráfico/Edições Afrontamento

Tiragem: 500 exemplares

Sede da Editora/Impressão/Encomendas: Edições Afrontamento, Rua de Costa Cabral, 859, 4200-225 Porto/

comercial@edicoesafrontamento.pt

Publicação apoiada por:

FCT Fundação para a Ciência e a Tecnologia MINISTÉRTO DA EDUCAÇÃO E CIÊNCIA

A ex æquo é uma revista com dupla arbitragem científica, sob anonimato.

DOI: https: / / doi.org/10.22355/ exaequo.2020.42.00

Indexação: SCOPUS - https://www.scopus.com/sources;

SciELO Citation Index da Thomson Reuters: SciELO Citation Index - http://wokinfo.com/ products_tools/multidisciplinary/scielo/;

SciELO/Portugal - Scientific Eletronic Library Online: http://www.scielo.mec.pt/scielo. php?script=sci_serial\&pid=0874-5560\&lng=pt;

DOAJ (Directory of Open Access Journals) - https://doaj.org/toc/2184-0385

SHERPA/RoMEO: http://www.sherpa.ac.uk/romeo/issn/0874-5560/pt/

Catálogo Latindex - Sistema Regional de Información en Línea para Revistas Científicas de América Latina, el Caribe, España y Portugal: http://www.latindex.unam.mx/latindex/ficha? folio=14734;

ERIH PLUS (European Reference Index for the Humanities): https://dbh.nsd.uib.no/publiseringskanaler/erihplus/periodical/info?id=482587;

Qualis CAPES (Brasil): https://qualis.capes.gov.br/

Nota: Ver composição do Conselho Científico e Estatuto Editorial no final da revista. 


\section{ÍNDICE}

Editorial.

Virgínia Ferreira

Dossier: Estudos de Género e Neoliberalismo: Os últimos 20 anos.

Coordenação de Maria João Silveirinha e Cláudia Álvares

Situacionismo de sexo: Um diagnóstico feminista à Plataforma de Pequim passados 25 anos

Cláudia Álvares, Maria João Silveirinha e Virgínia Ferreira

«Estudos sobre as mulheres» em Portugal Pós-Declaração de Pequim - Estudo bibliométrico das revistas ex æquo e Faces de Eva

Virgínia Ferreira, Cristina C. Vieira, Maria João Silveirinha,

Elizângela Carvalho e Priscila Freire

Dreaming the Welfare-State: Indian Women-Studies-Movement, Neoliberalism and Feminist Future

Cheshta Arora

Feminism and/in the/its plural.

Begonya Saez Tajafuerce

Academias de talento feminino: meios de emancipação ou ferramentas de reprodução social?

Susana Santos

Fazer o mesmo, sem ser o mesmo: Feminilidades, neoliberalismo e antifeminismo no contexto Godllywood Brasil

Monise Martinez

Surfando na onda digital: Feminismos em rede no Brasil

Raquel de Barros Pinto Miguel, Djenifer Samantha Marx

e Gilmara Joanol Arndt

Pós-feminismo, pós-racialismo e pós-colonialismo: A cobertura mediática da campanha de Joacine Katar Moreira

Rita Basilio de Simões e Inês Amaral

\section{Estudos e Ensaios}

A Igualdade de Género nas Organizações e o efeito do reconhecimento público: O Caso do Prémio Igualdade É Qualidade 
Architect Luz Valente-Pereira: Architecture, Research, and Life in a Changing Country

Patrícia Santos Pedrosa e Lia Gil Antunes

\section{Recensões}

Gender Studies and the New Academic Governance. Global Challenges, Glocal Dynamics and

Local Impacts, edited by Heike Kahlert. Wiesbaden, Springer, 2018, 289 pp.

Júlia Garraio

The Positioning and Making of Female Professors. Pushing Career Advancement Open, edited by Rowena Murray \& Denise Mifsud. Palgrave Studies in Gender and Education. Palgrave Macmillan, 2019, 241 pp.

Sofia Castanheira Pais

Revolución feminista y políticas de lo común frente a la extrema derecha, edited by María Eugenia Rodríguez Palop. Barcelona: Icaria, 2019, 151 pp.

Jana Soler Libran

Cuidar de quem cuida: histórias e testemunhos de um trabalho invisível. Um manifesto para o futuro, de José Soeiro, Mafalda Araújo e Sofia Figueiredo. Objectiva, Penguim Random House: Lisboa, 2020, 239 pp.

Manuel Abrantes

Números já publicados

Próximos números

Estatuto Editorial

Normas para submissão e avaliação de artigos

Declaração de ética e de boas práticas da ex æquo

Conselho Científico/Scientific Board

Os conteúdos dos textos publicados são da responsabilidade de quem os assina, não refletindo, necessariamente, a posição da APEM ou da Direção da ex æquo. 


\section{EDITORIAL}

\section{Virginia Ferreira}

(D) https: / / orcid.org/ 0000-0003-3838-054X

Neste quadragésimo segundo número da ex æquo dedicamos o dossier temático aos «Estudos de Género e Neoliberalismo: Os últimos 20 anos». A organização do dossier esteve a cargo de Maria João Silveirinha e Cláudia Álvares, ambas especialistas em estudos de género e estudos da comunicação.

Nesta edição da revista $e x ~ æ q u o$, reposicionamos a questão em torno dos Estudos sobre as Mulheres/de Género/Feministas (EMGF) na era neoliberal e olhamos para os últimos 20 anos do amplo campo dos estudos de género. No centro do nosso olhar estão as implicações para os EMGF da forma como a racionalidade económica neoliberal procura transformar as sociedades capitalistas e como, sob o seu regime, os governos deixam de ter uma responsabilidade prática ou ética perante o seu coletivo de cidadãs e cidadãos, abdicando das obrigações de nivelar o campo de ação para todas as pessoas prejudicadas pela discriminação sistémica e apelando à escolha individual e à responsabilidade pessoal como antídotos para as barreiras do preconceito e da discriminação. Entendemos que percorrer os últimos 20 anos da interceção entre género e neoliberalismo pode dar-nos algumas respostas que toquem não apenas os estudos de género, mas os caminhos dos feminismos nessas últimas duas décadas.

Esta temática foi a resposta que encontrámos para aceitar o desafio de refletir sobre o impacto da Plataforma da Ação de Pequim de 1995 que foi acordada precisamente quando o neoliberalismo se consolidava como prática política hegemónica, impondo uma racionalidade económica e uma subjetividade fortemente prejudiciais para as mulheres (precarização do emprego, retração do estado-providência, cortes nos serviços públicos, etc.), e acelerava o processo de substituição da cultura das humanidades pela da especialização e, em algumas áreas com estrondo, noutras paulatinamente, a polémica argumentativa pela polémica mediática... No texto de introdução à temática, tivemos a preocupação de mostrar que aos desenvolvimentos subsequentes à adoção da Plataforma não foram alheias as próprias conceções de género que nela estão vertidas.

Vale a pena chamar aqui a atenção para o texto no qual é apresentado o estudo bibliométrico das duas revistas publicadas em Portugal que se reclamam da área dos Estudos sobre as Mulheres/de Género/Feministas. Estamos a falar desta revista - a ex æquo - e a Faces de Eva, cujos primeiros números foram curiosamente publicados no mesmo ano - 1999, quatro anos depois da Plataforma. Ainda que enquanto variável proxi, pensamos que este estudo pode mostrar pelo menos parcialmente a forma como têm evoluído os perfis de quem publica nesta área de estudos e respetivas disciplinas, áreas geográficas e filiações institucionais, bem como o modo como o têm feito (em autoria singular ou plural), no período pós Plataforma. O desenvolvimento da análise temática, aqui apenas esboçada, 
dar-nos-á uma caracterização das transformações concetuais e analíticas com o passar dos anos. A hegemonização do conceito de género, sobre as questões das mulheres e feministas não pode deixar de ser vista como um claro efeito da promoção que dele é feito na Plataforma. Para além da confusão concetual introduzida foram progressivamente sendo secundarizados problemas que continuam a ser identificados nas sucessivas agendas políticas pós-Pequim 1995.

Na secção de Estudos e Ensaios, prosseguimos a nossa missão de dar visibilidade a medidas de política que procuram promover a igualdade e à obra de mulheres esmagadas pelo silêncio disciplinar e histórico. O primeiro da autoria de Mariana Pinheiro e Sara Falcão Casaca toma como tema "A Igualdade de Género nas Organizações e o Efeito do Reconhecimento Público: O Caso do Prémio Igualdade é Qualidade». Nele as autoras apresentam o estudo em que quiseram saber se as 41 organizações e empresas que foram distinguidas com o Prémio Igualdade é Qualidade, conferiram sustentabilidade e desenvolvimento às boas práticas de gestão de pessoas que lhes tinham justificado a atribuição do prémio. Explorando a informação institucional disponibilizada e as respostas a um inquérito por questionário, as autoras mostram mais uma vez como é mudar de forma estrutural as organizações. As 12 edições deste Prémio foram sempre entendidas como um instrumento político de efetivação de boas práticas de gestão de pessoas no trabalho, de uma gestão que promova a igualdade, que sustente o bem-estar de quem nelas trabalha.

No segundo texto desta secção damos visibilidade à arquiteta portuguesa Luz Valente-Pereira que, num tempo e numa sociedade hostil ao reconhecimento do trabalho e do talento das mulheres, conseguiu construir uma carreira na arquitetura, um campo em que as mulheres ainda só agora deixaram de ser olhadas como intrusas. O texto intitula-se «Architect Luz Valente-Pereira: Architecture, Research, and Life in a Changing Country» e é da autoria de Patrícia Santos Pedrosa e Lia Gil Antunes.

A secção de Recensões, por fim, apresenta-nos algumas obras a que vale a pena dar atenção: Júlia Garraio, muito a propósito, leu e refletiu sobre o livro Gender Studies and the New Academic Governance. Global Challenges, Glocal Dynamics and Local Impacts, editado por Heike Kahlert, para percebermos como o neoliberalismo nas universidades se repercutiu nos estudos de género e no lugar desta área científica na comunidade académica; Sofia Castanheira Pais dá-nos a conhecer The Positioning and Making of Female Professors. Pushing Career Advancement Open, editada por Rowena Murray e Denise Mifsud, que nos fala de trajetórias de professoras na academia; Jana Soler Libran revê outra coletânea, Revolución feminista y políticas de lo común frente a la extrema derecha, editada por María Eugenia Rodríguez Palop, que procura apontar caminhos para combater os movimentos antigénero; por fim, Manuel Abrantes sublinha a importância do manifesto Cuidar de quem cuida: histórias e testemunhos de um trabalho invisivel. Um manifesto para o futuro, de José Soeiro, Mafalda Araújo e Sofia Figueiredo.

A ex æquo quer continuar a ser útil na promoção do conhecimento produzido no âmbito dos EMGF, mas para isso tem que continuar a contar convosco - para contribuir com estudos originais e disseminar os que aqui são publicados. 


\section{Dossier}

Estudos de Género e Neoliberalismo: Os últimos 20 anos 



\title{
SITUACIONISMO DE SEXO: UM DIAGNÓSTICO FEMINISTA À PLATAFORMA DE PEQUIM PASSADOS 25 ANOS
}

\author{
Cláudia Álvares \\ (D) https: / / orcid.org/0000-0002-2882-5114 \\ Maria João Silveirinha* \\ (D) https: / / orcid.org/0000-0002-0702-3366 \\ Vinginia Ferreira \\ (D) https: / / orcid.org/0000-0003-3838-054X
}

\section{Resumo}

O artigo procura fazer uma análise feminista dos 25 anos da Plataforma de Ação Pequim através de uma discussão das ambiguidades com que os termos 'género' e mainstreaming foram introduzidos na Plataforma, refletindo sobre as ramificações e consequências da sua utilização no seu cruzamento com as políticas neoliberais que se foram consolidando nas últimas décadas. Em causa está o reconhecimento das múltiplas questões ligadas ao multiculturalismo subjacente ao modelo liberal de género e a proposta de formas de conceber um mainstreaming mais próximo das diversas experiências vividas e políticas especificamente direcionadas para responder às necessidades de grupos com necessidades particulares. Refletindo mais amplamente sobre os direitos das mulheres, o artigo termina defendendo que o direito à informação deve também abranger um direito à literacia.

Palavras-chave: Plataforma de Pequim; mainstreaming; neoliberalismo; sexo e género; multiculturalismo.

\section{Abstract}

Sex Situationism: A Feminist Diagnosis of the Beijing Platform 25 Years Later

The article aims to perform a feminist analysis of the 25 years of the Beijing Action Platform through a discussion of the ambiguities of the terms 'gender' and mainstreaming as introduced in the Platform, reflecting on the ramifications and consequences of their use in the intersection with increasingly consolidated neoliberal policies in recent decades. At issue is the recognition of the multiple issues related to multiculturalism underlying the liberal gender model and the proposal of ways of conceiving a mainstreaming closer to the

CIES/ISCTE-IUL, Instituto Universitário de Lisboa, 1649-026 Lisboa, Portugal.

Endereço Postal: Avenida das Forças Armadas, Sala 2W10, Edifício Sedas Nunes, 1649-026 Lisboa, Portugal.

Endereço eletrónico: claudia.alvares@iscte-iul.pt

* Univ Coimbra, Faculdade de Letras, 3004-530 Coimbra, Portugal; Membro da direção da Associação Portuguesa de Estudos sobre as Mulheres (APEM); Editora Associada da ex æquo.

Endereço postal: Faculdade de Letras, Largo da Porta Férrea, 3004-530 Coimbra, Portugal.

Endereço eletrónico: mjsilveirinha@gmail.com

*** Univ Coimbra, Faculdade de Economia, Centro de Estudos Sociais, 3000 Coimbra, Portugal; Presidente da direção da Associação Portuguesa de Estudos sobre as Mulheres (APEM); Diretora da ex æquo.

Endereço postal: Av. Dias da Silva, 165, 3004-512 Coimbra, Portugal.

Endereço eletrónico: virginia@fe.uc.pt 
diverse experiences and policies specifically directed at the needs of groups with particular needs. Reflecting more broadly on women's rights, the article ends by arguing that the right to information should also encompass a right to literacy.

Keywords: Beijing Platform; mainstreaming; neoliberalism; sex and gender; multiculturalism.

\section{Resumen}

Situacionismo de sexo: Un diagnóstico feminista de la Plataforma de Beijing 25 años después

El artículo busca un análisis feminista de los 25 años de la Plataforma de Acción de Beijing a través de una discusión de las ambigüedades con que los términos 'género' y 'transversalización' fueron introducidos en la Plataforma, reflexionando sobre las ramificaciones y consecuencias de su uso en su intersección con las políticas neoliberales que se han consolidado en las últimas décadas. Se trata del reconocimiento de las múltiples cuestiones relacionadas con la multiculturalidad que subyacen al modelo liberal de género y la propuesta de formas de concebir un mainstreaming más cercano a las diversas experiencias y políticas dirigidas específicamente a responder a las necesidades de colectivos con necesidades determinadas. Reflexionando más ampliamente sobre los derechos de las mujeres, el artículo finaliza defendiendo que el derecho a la información debe abarcar también el derecho a la alfabetización.

Palabras clave: Plataforma de Beijing; mainstreaming; neoliberalismo; sexo y género; multiculturalismo.

\section{Introdução}

Há mais de 50 anos que a questão da igualdade entre homens e mulheres está nos discursos das organizações internacionais. A Carta das Nações Unidas (1945) enfatizou, no seu Preâmbulo, a «igualdade de direitos dos homens e das mulheres» e a Declaração Universal dos Direitos Humanos (1948) proclamou que todas as pessoas tinham direitos e liberdades sem distinção, nomeadamente, de sexo (artigo $2^{\circ}{ }^{\circ}$ ). Tratava-se, nesta década, de assumir a igualdade formal, mas nas décadas de 1960 e 1970 o foco mudou para as mulheres através da agenda 'Mulheres em Desenvolvimento'. Na década de 1990 a abordagem da ONU mudaria, no entanto, de 'mulheres' (WID - Women in Development) para 'género' (GAD - Gender and Development), procurando uma estratégia para alcançar a igualdade de género mais relacional, que incluísse necessariamente homens e mulheres nos programas de desenvolvimento locais (Razavi \& Miller 1995; Ferreira 2002; Connell 2009).

A quarta Conferência Mundial sobre as Mulheres, decorrida entre 4 e 15 de setembro de 1995 em Pequim, adotou uma Declaração e uma Plataforma de Ação, com aprovação pela Assembleia Geral das Nações Unidas e, entre as reivindicações propostas tendo em vista a plena participação das mulheres em todos os setores da sociedade, público e privado, encontram-se a defesa de uma perspetiva de género que deve perpassar a formulação de políticas públicas ao nível do desen- 
volvimento económico, educação e formação, saúde, combate à violência, conflito armado, poder e tomada de decisões, mecanismos institucionais de promoção, direito humanos, media, ambiente e direitos das crianças do sexo feminino (Declaração de Pequim (DP)1995, 6).

A Plataforma reconhecia assim o 'género' como uma ferramenta importante para compreender e desafiar condições de reprodução das desigualdades entre mulheres e homens. A análise dos insucessos das políticas sob a perspetiva da primeira abordagem à promoção da igualdade nos programas de desenvolvimento, mostrou que, ao centrar esforços na promoção das mulheres (perspetiva WID), deixava intocados todos os setores das sociedades implicados nas práticas e nas representações marcadas pela lógica da subordinação das mulheres. A transição da ideia de 'mulheres' para 'género' não foi fácil e pode considerar-se que não só não foi alcançada, como contém, na sua génese, ambiguidades em torno da construção social da diferença e os aspetos relacionais da definição da feminilidade e da masculinidade (Antić \& Radačić 2011). Outras perspetivas nascidas na década de 90 incluindo as teorias queer e da interseccionalidade - complexificariam ainda mais as abordagens em questão, influindo nos termos adotados na Plataforma de Ação. Se as perspetivas feministas construtivistas sociais e queer também deram forma aos debates entre diferentes delegados/os e ativistas nas negociações que antecederam a Conferência de Pequim, a maioria dos governos e ativistas feministas usava o 'género' como sinónimo de 'mulheres' (Antić \& Radačić 2011; Girard 2007).

Seria preciso chegar à Convenção de Istambul, em 2011, para se gerar um amplo consenso de que o termo 'género' deveria ser definido de acordo com a abordagem construcionista social onde se lê, na alínea 3 c) que "Género' refere-se aos papéis, aos comportamentos, às atividades e aos atributos socialmente construídos que uma determinada sociedade considera serem adequados para mulheres e homens'.

Mas a ambiguidade com que, na Plataforma, o termo ' género' surgiu refletir-se-ia também no outro termo nela introduzido pela primeira vez: o mainstreaming.

No que se segue, discutimos as ramificações e consequências da utilização destes dois termos no seu cruzamento com as políticas neoliberais que se foram consolidando desde então.

\section{Plataforma de Ação: Ambivalências do Direito à Igualdade de Género}

A inclusão de uma perspetiva de género (DP 1995, Artigo 38, p. 5) coexiste, na Declaração de Pequim, com uma conceção de direitos humanos das mulheres e das crianças do sexo feminino enquanto 'parte inalienável, integral e indivisível dos direitos humanos universais' (DP 1995, Artigo 2, p. 7), conceção essa que é referida com frequência ao longo do texto como algo particularmente distintivo no tocante à implementação de políticas favoráveis à afirmação da autonomia da 
mulher. Se por um lado se enfatiza a importância de uma perspetiva de género na formulação de políticas públicas nesta Declaração, por outro lado também se afirma, assim, a cooptação dessa perspetiva de género por uma conceção universalista dos direitos humanos que se compromete com o estabelecimento de igualdade de direitos, responsabilidades, oportunidades e participação de 'mulheres e homens' na criação e implementação de políticas públicas tanto intersectoriais como transversais aos níveis 'nacional, regional e internacional' (DP 1995, cláusula 36, p. 5).

Por outras palavras, a declaração de Pequim presta-se a ser criticada por abrir caminho a uma institucionalização de género que se baseia essencialmente numa conceção de sexo não-desconstrutivista, ao mesmo tempo que não tem em conta aspetos relacionais de género, poder e ideologia, assim permitindo negligenciar a questão da reprodução de padrões de subordinação ao representar o 'género' enquanto variável dicotómica (Baden \& Goet 1997).

Por ter vindo a representar, grosso modo, um posicionamento tomado a título global sobre os direitos das mulheres (Buss 1998), estas fissuras, ou tensões, em torno da utilização do termo 'género' tornam-se particularmente relevantes por conduzirem a uma presumível despolitização do termo, fazendo-o corresponder a 'mulher'. Efetivamente, segundo Buss, seis meses antes da Conferência, grupos conservadores tinham feito campanha contra a inclusão do termo 'género', por considerarem que, ao se aproximar de uma noção socialmente construída e, por conseguinte, mutável de 'identidade', estaria eivado de um posicionamento ideológico que arriscaria desestabilizar uma relação normativa entre género e identidade sexual (Buss 1998).

Segundo estas críticas, a institucionalização do termo 'género' resultante da adoção da Declaração surge a partir de uma tentativa de se condicionar um entendimento de género próximo do sexo, sacrificando, neste processo, a formulação de políticas públicas mais ambiciosas. Por detrás deste posicionamento defensor de uma conceção desconstrutivista de género poderá encontrar-se a visão do feminismo liberal de Okin, que apelava à possibilidade de se ir para além de reivindicações de igualdade de acesso a posições, benefícios e oportunidades, tais como correntemente definidos, insistindo numa revisão crítica dos sistemas que os determinam. Apenas uma visão assente num ideal de universalidade dos direitos humanos que fosse para além de qualquer especificidade dos direitos das mulheres, reificadas no sexo, poderia, de acordo com Okin (2000), conduzir a uma maior justiça social. As ideias de Okin, consentâneas com uma visão de neutralidade dos direitos assente na não particularização do sexo feminino, procuravam proteger o ideal da 'igualdade de género' contra reclamações concorrentes da parte de defensores quer do multiculturalismo, quer da teoria do desenvolvimento económico. Okin receava que, num contexto de relativismo cultural, o privilegiar de direitos específicos às mulheres pudesse abrir caminho a isenções da parte daqueles que, por motivos de tradição ou costume, violassem os direitos das mulheres. 
Simultaneamente, não concordava com a visão dos direitos das mulheres inerentes aos programas de ajustamento estrutural disseminados por organizações como o Banco Mundial ou o Fundo Monetário Internacional (FMI), que erguiam o estandarte da igualdade de direitos como meio para atingir o desenvolvimento económico, isto é, a essência do business case - gender equality is good for business, e não enquanto fim em si mesmo, distanciando então esses direitos de qualquer discussão mais alargada em torno da justiça social (Enslin \& Tjiattas 2006; Okin 2003).

O entendimento de género transversal à Declaração e Plataforma de Ação de Pequim revela-se assim algo ambivalente a dois níveis: primeiro, não permite destrinçar de forma clara entre género e sexo; segundo, se por um lado defende a formulação de políticas públicas a partir de uma perspetiva de género, por outro lado defende que o género seja incluído no âmbito dos direitos humanos universais. Esta ambivalência pode abrir caminho a tensões na formulação de políticas públicas que se baseiam na promoção 'ativa e visível' do mainstreaming de perspetivas de género em todas as esferas da sociedade, a partir de 'políticas e programas' dos Governos nacionais numa escala global (Plataforma de Ação 1995, cláusulas $25,79,105,123,124,141,164,187,189,201,202,205,229,231,238,252,273$, $292,309,320,326)$. A preocupação em evitar redutos específicos à área de género sobressai na cláusula 309, em que se faz menção específica à necessidade de se 'prevenir uma marginalização que possa ocorrer inadvertidamente', por oposição a uma 'integração da dimensão de género em todas as operações'. Reforça-se assim um olhar liberal na retórica transnacional sobre a implementação do mainstreaming de género por parte da Plataforma de Ação, correndo-se o risco de se obscurecer a diversidade temporal e local de contextos no tocante à adoção dos mecanismos necessários à promoção de igualdade de género aos níveis nacionais (HafnerBurton \& Pollack 2002). Exclui-se, desta forma, uma resposta que vá ao encontro das especificidades das 'condições sociais e nuances culturais' que surtem impacto sobre as relações de género, mesmo que existam estruturas facilitadoras para a implementação de alguns mecanismos transnacionais conducentes à promoção de uma maior igualdade de oportunidades e justiça social (Keddie 2010).

\section{O Mainstreaming de Género e o Afastamento de Objetivos Políticos Feministas}

Segundo Rees (1998), haverá três tipos-ideais de abordagem às questões de género, nomeadamente, a igualdade de oportunidades, a ação positiva e o mainstreaming de género. A primeira assenta na ideia de que os direitos humanos são para todos, não podendo haver indivíduo algum com menos direitos do que outro, o que implica a criação de condições de igualdade de oportunidades para assegurar, por exemplo, o direito a salário igual para trabalho igual. Foi a ideia norteadora da primeira fase das políticas de igualdade, que tiveram como principal obje- 
tivo erradicar da lei, na medida do possível, medidas discriminatórias e fornecer reparação para as pessoas cujos direitos são violados. Centra-se nos direitos individuais e procura fornecer remédios (remendos) legais. A segunda abordagem remete para a ação positiva (afirmativa, no contexto americano), ou discriminação positiva, em que a «a ênfase passa da igualdade de acesso à criação de condições mais suscetíveis de conduzir à igualdade de resultados» (Rees 1998, 34). Tal envolve a adoção de ações específicas, como a introdução de quotas mínimas de mulheres para certas funções e posições sociais, em que estão sub-representadas, e a provisão de oportunidades de formação/reforço de competências em áreas profissionais em que as mulheres são deficitárias, por forma a aumentar a representação e superar a desigualdade de posições de 'ponto de partida' em sociedades patriarcais. Centra-se nas desvantagens de grupo e elabora projetos e medidas «especiais», tendo em vista a adaptação do grupo em desvantagem. A terceira abordagem corresponde ao mainstreaming de género, o qual foi adotado pela Plataforma de Ação de Pequim, baseando-se na incorporação sistemática das questões de género no âmbito da formulação geral de políticas públicas institucionais e governamentais (Scholten, Collett \& Petrovic 2016; Verloo 2005). Na base da sua adoção, está a convicção de que possibilita a transformação social desejada a montante, centrando-se nos sistemas e estruturas que estão na base das desvantagens das mulheres e que, desta forma, veem a sua neutralidade posta em causa. Adota como visão o combate do sexismo institucionalizado.

Aplicado aos estudos de género desde inícios dos anos 2000, o mainstreaming procurava transcender um olhar específico e 'nichificado' sobre as mulheres ao defender que os seus direitos, enquanto parte integrante dos direitos humanos, deveriam ser alvo de políticas genéricas que não fossem construídas em função da especificidade de género. A governança baseada no equilíbrio entre o Estado, a sociedade civil e o mercado, instância promotora da transparência no ato de governar e de uma consciência geral relativa a assuntos como os de género, torna-se assim peça fundamental da mobilização de consciências através de um mainstreaming que se define como a «(re)organização, melhoria, desenvolvimento e avaliação dos processos de tomada de decisão, por forma a que a perspetiva de igualdade de género seja incorporada em todas as políticas, a todos os níveis e em todas as fases, pelos intervenientes normalmente envolvidos na elaboração de políticas públicas» (Conselho da Europa 1998). Afastando-se assim de uma dimensão 'estatocêntrica' na coordenação de políticas de integração a partir de um 'centro' nacional hierárquico, agregador de competências, a governança passa então a orientar-se para uma dimensão mais policêntrica e participativa, baseada numa abordagem fragmentada que perpassa vários níveis de competências (Scholten, Collett \& Petrovic 2016).

Se a primeira abordagem, emergente na década de 70, relativa à implementação de ações conducentes a uma maior igualdade de género, tem sido criticada por tender a focar-se quase exclusivamente nos direitos das mulheres enquanto trabalhadoras, escudando-se a endereçar as causas mais insidiosas da desigualdade nos 
domínios informais do quotidiano, a segunda abordagem, surgida na década seguinte como resultado dos insucessos da primeira, incidindo sobre as ações positivas, tem vindo a revelar-se controversa devido ao facto de estimular um tratamento desigual tendo em vista a promoção da igualdade. Recai, no âmbito desta segunda abordagem, a possibilidade de se introduzirem quotas temporárias em áreas em que as mulheres estejam em minoria, o que tem suscitado uma variedade de críticas de diversa natureza entre as quais se destaca a de não atender ao mérito individual (Henriques 2006, 278; Rees 1998, 32). A terceira e última abordagem assenta num mainstreaming de género que procura trazer uma dimensão de género a todas as dimensões e níveis da governança, nomeadamente o transnacional, sendo ativamente promovida por organizações intergovernamentais como a União Europeia, o Programa de Desenvolvimento das Nações Unidas e o Banco Mundial, e o nacional, tendo sido adotada como política pública oficial em muitos países industrializados. No entanto, conforme afirmam Hafner-Burton e Pollack (2002, 342), esse objetivo implica um grau de compromisso difícil de cumprir, atendendo ao facto de muitos dos atores envolvidos na formulação de políticas públicas «terem pouca experiência ou interesse por temas relacionados com género» ou, como Ferreira sublinha, dificilmente os intervenientes 'habituais' podem protagonizar um processo técnico e político que requer mudanças de todos os intervenientes, tanto em termos de cultura organizacional quanto em termos de maneiras de pensar, de definir objetivos e estruturas e de distribuir recursos $(2002,66 / 67)$. Perante a incapacidade de o Estado se reformar a si próprio, o mainstreaming, em vez de conduzir a uma reconfiguração de objetivos da organização segundo uma perspetiva de género, reduz-se, na maior parte das vezes, a uma abordagem integracionista, segundo a qual se procura integrar as mulheres e as questões de género no âmbito de políticas existentes (Jahan 1995).

A implementação de medidas de mainstreaming tendo em vista a reconfiguração de políticas de acordo com uma dimensão de género implicaria a adoção dos seguintes procedimentos: a produção de informação estatística desagregada por sexo para indicadores como emprego, rendimento, instrução, acesso à saúde, etc., de forma a que se possa identificar a desigualdade de género quer para criar políticas e programas relevantes, quer para se avaliar a sua implementação ongoing e a posteriori; a formação em questões de género com o objetivo de se capacitar quem trabalha numa organização com as ferramentas necessárias à implementação e avaliação de programas destinados ao mainstreaming de género; a avaliação do impacto das medidas de mainstreaming implementadas bem como a revisão da linguagem empregue em propostas de mainstreaming, por forma a aferir os efeitos diferenciais sobre homens e mulheres, endereçando potenciais desequilíbrios; a elaboração de manuais para promover a integração de uma perspetiva de género no local de trabalho, bem como listas de controlo que permitam a quem formula políticas públicas verificar se as preocupações de género estão a ser efetivamente incorporadas em determinado setor, facilitando ainda a avaliação de impacto das 
medidas tomadas; a criação de mecanismos de monitorização internos às empresas ou então assegurados por entidades externas, tais como ONG, tendo em vista a garantia do cumprimento dos critérios de mainstreaming de género, com base na avaliação da eficácia de determinada política ou método (Hafner-Burton \& Pollack 2002, 352-53).

Apesar da adoção do mainstreaming de género ter sido encarada como uma das vitórias da Plataforma de Ação de Pequim, esta iniciativa tem também sido alvo de críticas substantivas, essencialmente devido ao facto das questões de género se terem convertido em metas a atingir, com base nas quais se avalia a 'performance' de uma empresa ou de um país, assim se distanciando dos objetivos de transformação social originalmente subjacentes ao conceito. A banalização de uma retórica associada ao 'género', quer por governos, quer por organizações para o desenvolvimento, arrisca-se a reduzir o mainstreaming a uma série de procedimentos, instrumentos e burocracias próprios, os quais se tem de cumprir por forma a garantir que uma análise baseada em género ingresse no domínio das políticas públicas. Neste processo, a formulação de políticas públicas sob uma perspetiva de género corre o risco de se converter num projeto governamental profissionalizado e financiado por entidades externas transnacionais, tal como a Comissão Europeia, afastando-se de estratégias e objetivos políticos feministas (Milward, Mukhopadhyay \& Wong 2015, 76) enraizados em conhecimento de realidades locais. Por detrás desta situação, estão os enquadramentos habituais das elites dominantes, sejam estas nacionais ou internacionais. Para que o novo enquadramento relativo ao mainstreaming de género pudesse ser aceite por estas elites, aquele terá sido obrigado a encaixar-se dentro de narrativas já existentes, originando assim um enquadramento que remete, em muitos aspetos, para uma ideologia liberal assente no desenvolvimento e progresso económicos (Snow \& Benford 2000 apud Hafner-Burton \& Pollack 2002, 346; Fraser 2009).

\section{Princípios Liberais do Mainstreaming num Contexto Neoliberal}

O facto de o ideário liberal se encontrar nas entrelinhas do mainstreaming de género está patente na promoção dos direitos humanos das mulheres como meio para se atingir o crescimento económico e bem-estar social, sendo que a Declaração de Pequim pode ser considerada como um documento regulador para esse efeito. Estabelece-se, assim, uma correlação entre progresso económico, social e cultural, tornando-se a 'igualdade de género' num importante indicador civilizacional, mas não como um valor humano intrínseco.

Efetivamente, num contexto pautado por uma cada vez mais intensa imigração para a Europa, como o da atualidade, os ideais do feminismo liberal surgem por vezes associados aos de uma nova (extrema) direita na Europa, em que altas figuras políticas femininas como Marine Le Pen, líder do partido francês Le Rassemblement 
National, Anne Marie Waters, líder do partido anti-islâmico britânico For Britain, e Alice Weidel, co-líder do Alternative für Deutschland (AfD) combinam retórica anti-imigrante e antifeminista, tendencialmente enquadrada de acordo com um princípio organizador anti-Islão (cf. Álvares 2019). Estas mulheres dirigentes de partidos e movimentos conservadores defendem os valores tradicionais manejando argumentos que atribuem ao feminismo - é enquanto mulheres empoderadas que dizem permitir-se fazer as escolhas da tradição. Ou seja, este entendimento do feminismo vai ao encontro dos princípios liberais do mainstreaming, os quais não atendem à interseccionalidade (Crenshaw 1989, 25) entre eixos de opressão, como género e raça, considerando antes haver um modelo de desenvolvimento - cada vez mais neoliberal - a ser difundido a uma escala global, tendo em vista a promoção do bem-estar económico e social. Aqueles que não cumprem este modelo económico que serve de enquadramento ao mainstreaming não só não são vistos como passíveis de serem enquadrados dentro dos ideais civilizacionais de progresso permanente, onde benefícios macroeconómicos se cruzam com a implementação de princípios igualitários (Elomäki 2015), como chegam a sofrer sanções pecuniárias pela resistência à adesão a valores iminentemente iluministas - tome-se, a título de exemplo, o facto de diversas instituições transnacionais fazerem depender a atribuição de subsídios ao cumprimento de metas de mainstreaming.

Efetivamente, não se trata aqui de apregoar um relativismo cultural que convive bem com o fechar de olhos a situações de clara discriminação contra as mulheres em diversas partes do mundo, porque a resistência aos valores iluministas funda-se nos «relativismos culturais» que, em geral, deixam as mulheres em posições de subalternidade, quando não as violentam «em nome de superiores valores culturais» (como sejam a mutilação genital feminina, a morte por lapidação, etc. ou a cultura da violação tão corrente ainda em todas as sociedades incluindo a nossa...). Antes, implica o reconhecimento de que existe toda uma discussão ligada ao multiculturalismo subjacente ao modelo liberal de género, modelo esse veiculado através da Plataforma de Ação de Pequim. O mainstreaming de género articula uma conceção de género semelhante à da cidadania do modelo republicano promovido por um Estado centralizado, como o francês, não dando lugar ao particularismo da diferença na medida em que todas as pessoas são vistas como tendo a mesma identidade cultural partilhada e uniformizada, com os mesmos direitos e deveres daí decorrentes na esfera pública (Dressler et al. 2012). Se a igualdade sobressai como fator potencialmente totalitário num Estado centralizador, por abstrair cidadãos e cidadãs dos seus contextos de vivência responsáveis pela formação da experiência como se de autómatos se tratassem, essa mesma lógica aplicada a um modelo de igualdade de género, o qual se pretende estender ao nível transnacional, revela-se ainda mais totalitário devido à escala envolvida. Conforme afirma Dahlgren $(2002,8)$, a teoria democrática liberal tradicional pressupõe a existência de uma pessoa cidadã com maturidade plena, que parece sair magicamente de uma caixa negra sociocultural, pronto a desempenhar o seu papel na democracia. 
Numa perspetiva menos impositiva, então, dir-se-ia que a primeira dimensão a ter em conta para conceber um mainstreaming mais próximo das diversas experiências vividas pelas mulheres e pelos homens consistiria na formulação de políticas especificamente direcionadas para responder às necessidades de grupos específicos, com necessidades próprias em função da idade, da classe social, da orientação sexual, da religião, da nacionalidade, da capacidade funcional, etc. Ao se ter orientado o mainstreaming para a formulação de políticas de cariz genérico, menorizou-se a possibilidade de se construirem grupos-alvo com base na interseccionalidade da experiência, embora com uma base no substantivismo do sexo feminino e do sexo masculino, variando esta experiência de acordo com o contexto em que qualquer mulher ou homem se insere em termos de espaço e de tempo (Scholten, Collett \& Petrovic 2016). Há, na Plataforma de Ação de Pequim, um pano de fundo comum sobre o qual toma forma um modelo de igualdade assente numa identidade de sexo articulada ao nível transnacional, apesar das especificidades de experiências interseccionais com outras categorias de 'opressão'.

O ter-se optado, na Declaração de Pequim, pela utilização do termo género em vez de sexo deve ser alvo de reflexão. Se for de género que se trata e não de sexo, então o entendimento mais desconstrutivista de género como encenação e repetição de atos performativos no quotidiano terá certamente de ser mais tido em conta do que o é na Plataforma de Ação de Pequim. O conceito de género que transparece quer na Declaração de Pequim, quer em ações de mainstreaming defendidas pela Plataforma de Ação aparenta apontar mais para o substantivismo do sexo do que para uma desconstrução pós-marxista ou pós-moderna de género.

O substantivismo de sexo deveria ser assumido por forma a servir de plataforma de reivindicação dos direitos das mulheres, específicos às mulheres, de forma contundente. A reivindicação desses direitos sob uma integração num quadro mais alargado de direitos humanos faz com que se corra o risco de desvirtuar a especificidade dos direitos das mulheres, dificultando a adoção de uma perspetiva de 'género' que perpasse as políticas públicas. Atendendo ao facto de os direitos humanos serem herdeiros de todo um legado masculinista de violência simbólica (Nicholas \& Agius 2018), este seu enquadramento poderá condicionar a interpretação dos direitos das mulheres, distanciando-os de uma especificidade própria e impedindo que se alarguem para fazer face a uma situação social em evolução constante.

\section{Notas finais}

Por fim, há que ressaltar que o modelo de mainstreaming de género se enquadra cada vez mais numa narrativa neoliberal de competitividade e individualismo, servida por uma conceção de inserção no mercado laboral que privilegia a ascensão profissional daquela que vence todos os obstáculos e sobressai entre os pares 
'apesar' de ser mulher. Nesta perspetiva, como tem sido apontado, os pressupostos da teoria económica neoclássica, os quais contribuem para que o modelo social europeu se torne cada vez mais neoliberal e flexível, legitimam determinadas prioridades e políticas económicas (Elomäki 2015; Rubery 2015), antagónicas a uma igualdade de género nas esferas pública e privada, que passe necessariamente pela valorização das tarefas do cuidado (Fraser 2009). Efetivamente, os cortes no investimento público bem como a desregulação do mercado laboral, que testemunhamos em vários países devido às crises de dimensão global, podem ter impacto ao nível do mainstreaming de género, pois este vê-se obrigado a adaptar-se a novos enquadramentos ditados por narrativas políticas dominantes. O discurso da meritocracia (Arruzza et al. 2019), que reina em contextos neoliberais, faz com que nos distanciemos de um ideal coletivo de igualdade, potenciando o agravamento das desigualdades sociais.

Exploramos, ao longo do texto, os sentidos dos termos mainstreaming e 'género' como usados na Plataforma, a um nível paradigmático, se quisermos. Mas não esquecemos que nos contextos neoliberais altamente mediatizados da última década estes mesmos termos provocam hoje resistências com sentidos totalmente opostos às críticas atrás referidas. Os movimentos antigénero que surgiram em resposta direta às tentativas feministas e queer de inserir novos entendimentos de género, sexo e sexualidade na política internacional combatem aquilo a que chamam 'ideologia de género' e uma 'colonização ideológica' que tem por objetivo destruir a família tradicional, ao apoiar a adoção de crianças e o casamento de pessoas do mesmo sexo (Corredor 2019). A convergência das forças conservadoras e do neoliberalismo não pode, com efeito, ser dissociada dos meios digitais por onde elas propagam, se organizam e se cruzam em resposta não apenas aos ativismos digitais crescentes, mas também com os princípios de um crescente entendimento do empoderamento como capacidade de consumo.

Com efeito, a sustentação do feminismo em ideologias de mercado torna-se cada vez mais visível através da sua mediatização, contribuindo esta para o sucesso de um feminismo popular, baseado na ideia de escolha individual, no empreendedorismo, na cultura de consumo corporativa e na mercantilização de fragmentos de retórica feminista (Banet-Weiser et al. 2018, 2020; McRobbie 2008).

Por outro lado, a mediatização crescente da sociedade, ligada à convergência digital, dá lugar ao surgimento de velhos problemas de discriminação associados a novas configurações de misoginia online. Se o enfoque na Plataforma de Ação de Pequim, no tocante aos legacy media, estava centrado na representação estereotipada das mulheres, agora vivemos uma época em que muitas mulheres, enquanto produsers dos meios digitais, também contribuem para ativamente e em consciência reproduzir esses estereótipos, procurando emancipar-se através da dissolução da sua conotação negativa. Num contexto caraterizado pela aparente descorporalização devido à natureza de um ambiente virtual que oferece um certo grau de anonimato (Álvares 2018), as formas offline de discriminação e de violência de 
género são amplificadas online, com consequências significativas ao nível do seu alcance e difusão. $\mathrm{O}$ direito à informação enquanto parte integrante dos direitos humanos deve então também abranger um direito à literacia direcionado às mulheres, por forma a que estas aprendam a proteger o seu direito à imagem e à privacidade num contexto em que as fronteiras entre público e privado se tornam progressivamente mais ténues.

\section{Referências bibliográficas}

Alvares, Claudia. 2018. «Online staging of femininity: disciplining through public exposure in Brazilian social media». Feminist Media Studies 18(4), 657-674. DOI: https: / doi.org / 10.1080/14680777.2018.1447336

Álvares, Cláudia. 2019. «O ‘Femonacionalismo' enquanto Violação de Categorias de Identidade: A Face Renovada da Extrema-Direita Europeia». Revista de Comunicação e Linguagens 51, 50-60.

Antić, Marija, and Ivana Radačić. 2020. «The evolving understanding of gender in international law and 'gender ideology' pushback 25 years since the Beijing conference on women». Women's Studies International Forum. Vol. 83. DOI: https:/ / doi.org/10.1016/ j.wsif.2020.102421

Arruzza, Cinzia, Tithi Bhattacharya, and Nancy Fraser. 2019. Feminism for the 99\%: A Manifesto. Londres: Verso.

Baden, Sally, Anne Marie Goetz. 1997. «Who Needs [Sex] When You Can Have [Gender]? Conflicting Discourses on Gender at Beijing.» Feminist Review 56, 3-25.

Banet-Weiser, Sarah. 2018. Empowered: Popular Feminism and Popular Misogyny. Durham: Duke University Press.

Banet-Weiser, Sarah, Rosalind Gill, and Catherine Rottenberg. 2020. «Postfeminism, Popular Feminism and Neoliberal Feminism? Sarah Banet-Weiser, Rosalind Gill and Catherine Rottenberg in Conversation». Feminist Theory 21(1), 3-24. DOI: https:/ / doi.org/10.11 $77 / 1464700119842555$

Buss, Doris. 1998. «Robes, Relics and Rights: the Vatican and the Beijing Conference on Women». Social \& Legal Studies 7(3), 339-363. DOI: https: / / doi.org/10.1177/096466399 800700302

Connell, Raewyn. 2009. Gender in world perspective. Cambridge: Polity Press.

Corredor, Elizabeth. 2019. «Unpacking «gender ideology» and the global right's antigender countermovement». Signs: Journal of Women in Culture and Society, 44(3), 613-638. DOI: https: / / doi.org/10.1086/701171

Council of Europe. 1998. Conceptual Framework, Methodology and Presentation of Good Practices: Final Report of Activities of the Group of Specialists on Mainstreaming [EG-S-MS (98) 2]. Strasbourg. https:/ / www.unhcr.org/3c160b06a.pdf (acedido a 08.11.2020)

Crenshaw, Kimberle. 1989. «Demarginalizing the Intersection of Race and Sex: A Black Feminist Critique of Antidiscrimination Doctrine, Feminist Theory and Antiracist Politics». University of Chicago Legal Forum Vol. 1989, Article 8, https://chicagoun bound.uchicago.edu/uclf/vol1989/iss1/8/ (acedido a 07.11.2020)

Declaração de Pequim e Plataforma de Ação da IV Conferência Mundial sobre a Mulher (Beijing Declaration and Platform for Action of the The Fourth World Conference on 
Women) (1995), https: / / www.un.org/en/events / pastevents/pdfs / Beijing_Declaration_and_Platform_for_Action.pdf (acedido a 05.11.2020)

Dhar, Suneeta. 2018. «Gender and Sustainable Development Goals (SDGs)». Indian Journal of Gender Studies 25(1), 47-78. DOI: 10.1177/0971521517738451

Dressler, Wanda, Hakan G. Sicakkan, Artan Fuga, Veronica Mitroi, and Liza Terrazzoni. 2012. «The French Republican model, the European Diversity Perspective and the European Public Sphere». Social Science Information 51(3), 418-447. DOI: 10.1177 / 05390 18412445252

Elomäki, Anna. 2015. «The economic case for gender equality in the European Union: Selling gender equality to decision-makers and neoliberalism to women's organizations». European Journal of Women's Studies 22(3), 288-302. DOI: $10.1177 / 1350506815571142$

Enslin, Penny, and Mary Tjiattas. 2006. «Educating for a just world without gender.» Theory and Research in Education 4(1), 41-68.

Ferreira, Virgínia. 2002. «La mondialisation des politiques d'égalité : du réformisme social au réformisme d'État». Cahiers du Genre, 33, Paris, L'Harmattan, 63-83.

Fraser, Nancy. 2009. «Feminism, capitalism and the cunning of history». New Left Review 56 (March/April): 97-117.

Girard, Françoise. 2007. «Negotiating sexual rights and sexual orientation at the UN». In R. Parker, R. Petchesky, \& R. Sember (Eds.), SexPolitics: Reports from the front lines (pp. 311-359). Sexuality Policy Watch https:/ / www.sxpolitics.org/frontlines/book/pdf/ capitulo9_united_nations.pdf (acedido a 05.11.2020)

Hafner-Burton, Emilie, and Mark A. Pollack. 2002. «Mainstreaming Gender in Global Governance». European Journal of International Relations 8(3), 339-373. DOI: https:// doi.org/10.1177/1354066102008003002

Henriques, José. 2006. «O princípio da igualdade de tratamento e a discriminação positiva». Revista de Estudos Politécnicos Vol. III (5/6), 263-280.

Jahan, Rounaq. 1995. The Elusive Agenda: Mainstreaming Women in Development. Atlantic Highlands, NJ: Zed Books.

Keddie, Amanda. 2010. «Neo-liberalism and new configurations of global space: possibilities, tensions and problematics for gender justice». Journal of Gender Studies 19:2, 139-152. DOI: https: / / doi.org/10.1080/09589231003695864

Milward, Kirsty, Maitrayee Mukhopadhyay, and Franz F. Wong. 2015. «Gender Mainstreaming Critiques: Signposts or Dead Ends?». IDS Bulletin 46(4): 75-81.

Nicholas, Lucy, and Christine Agius. 2018. «Introduction». In: The Persistence of Global Masculinism edited by Lucy Nicholas and Christine Agius, pp. 1-29. Cham, Switzerland: Palgrave Macmillan.

Okin, Susan. 2000. «Feminism, Women's Human Rights, and Cultural Differences.» In: Uma Narayan, \& Sandra Harding (org.) Decentering the Center: Philosophy for a Multicultural, Postcolonial, and Feminist World. Bloomington, Indiana: University of Indiana Press.

Okin, Susan. 2003. «Poverty, Well-Being, and Gender: What Counts, Who's Heard?». Philosophy \& Public Affairs, 31(3), 280-316.

Razavi Shahra, and Carol Miller. 1995. «From WID to GAD: Conceptual Shifts in the Women and Development Discourse». Geneva, UNRISD, Occasional Paper, $\mathrm{n}^{\circ} 4$.

Rees, Teresa. 1998. Mainstreaming Equality in the European Union: Education, Training and Labour Market Policies. New York: Routledge.

Rubery, Jill. 2015. «Austerity and the Future for Gender Equality in Europe». ILR Review 68(4), 715-741. https: / / doi.org/10.1177/0019793915588892 
Cláudia Álvares. Professora Associada do Departamento de Sociologia do ISCTE-Instituto Universitário de Lisboa; Investigadora integrada do Centro de Investigação e Estudos de Sociologia (CIES). Membro da Direção da Associação Portuguesa de Estudos sobre as Mulheres. Docência universitária e investigação na área de confluência entre os Estudos de Media, os Estudos Feministas e as Políticas de Identidade.

Endereço eletrónico: claudia.alvares@iscte-iul.pt

Maria João Silveirinha. Professora Associada da Faculdade de Letras da Universidade de Coimbra. Membro integrado do Centro de Investigação ICNova - Instituto da Comunicação da Nova. Membro da Direção da Associação Portuguesa de Estudos sobre as Mulheres. Docência universitária e investigação na área das Ciências da Comunicação, com particular interesse no cruzamento destas com as questões de género na comunicação e nos media.

Endereço eletrónico: mjsilveirinha@gmail.com

Virgínia Ferreira. Professora Associada da Faculdade de Economia da Universidade de Coimbra (FEUC); Investigadora do Centro de Estudos Sociais (CES). Socióloga, com interesses de pesquisa sobre as desigualdades no mercado de trabalho, exclusão social, equilíbrio trabalho/vida familiar e políticas de igualdade sexual. Membro fundador da Associação Portuguesa de Estudos sobre as Mulheres. Tem publicado em revistas e coletâneas nacionais e internacionais.

Endereço eletrónico: virginia@fe.uc.pt 


\title{
«ESTUDOS SOBRE AS MULHERES» EM PORTUGAL PÓS-DECLARAÇÃO DE PEQUIM - ESTUDO BIBLIOMÉTRICO DAS REVISTAS EX AEQUO E FACES DE EVA
}

\author{
Virginia Ferreira * \\ (D) https: / / orcid.org/0000-0003-3838-054X \\ Cristina C. Vieira* \\ (D) https: / / orcid.org / 0000-0002-9814-1076 \\ Maria João Silveirinha: \\ (D) https: / / orcid.org/0000-0002-0702-3366 \\ Elizângela Carvalho \\ (D) https: / / orcid.org/0000-0001-8341-2016 \\ Priscila Freire \\ (D) https: / / orcid.org/ 0000-0003-4031-543X
}

\section{Resumo}

Neste artigo fazemos a primeira apresentação e discussão de um conjunto de resultados parcelares do estudo bibliométrico das revistas ex æquo e Faces de Eva. A partir dos 259 textos da Faces de Eva e 399 da ex æquo, publicados entre 1999 e 2019, foi construída uma base Portugal; Presidente da direção da Associação Portuguesa de Estudos sobre as Mulheres (APEM); Diretora da ex æquo.

Endereço postal: Av. Dias da Silva, 165, 3004-512 Coimbra, Portugal.

Endereço eletrónico: virginia@fe.uc.pt

** $\quad$ Universidade de Coimbra, Faculdade de Psicologia e Ciências da Educação, 3001-802 Coimbra; Universidade do Algarve, CEAD-Centro de Investigação em Educação de Adultos e Intervenção Comunitária, 8005-139 Faro, Portugal; Vice-Presidente da direção da Associação Portuguesa de Estudos sobre as Mulheres (APEM); Editora Associada da ex æ⿱㇒⿻二丨䒑o.

Endereço postal: Rua do Colégio Novo, 3001-802 Coimbra, Portugal.

Endereço eletrónico: vieira@fpce.uc.pt

**** Universidade de Coimbra, Faculdade de Letras, 3004-530 Coimbra, Portugal; Membro da direção da Associação Portuguesa de Estudos sobre as Mulheres (APEM); Editora Associada da ex æq quo. Endereço postal: Faculdade de Letras, Largo da Porta Férrea, 3004-530 Coimbra, Portugal.

Endereço eletrónico: mjsilveirinha@gmail.com

*.:m* Doutoranda de Ciências da Comunicação da Faculdade de Letras, 3004-530 Coimbra, Universidade de Coimbra.

Endereço postal: Rua António José de Almeida, 86, 1E, 3000-041, Coimbra, Portugal.

Endereço eletrónico: elizc.noronha@gmail.com

****** Doutoranda de Sociologia da Faculdade de Economia da Universidade de Coimbra, 3004-512 Coimbra, Portugal; Escola Normal Superior da Universidade do Estado do Amazonas. CEP 69050-010 Manaus - AM. Brasil.

Endereço postal: Escola Normal Superior da Universidade do Estado do Amazonas. Av. Djalma Batista, 3578 - Flores - CEP 69050-010 Manaus-AM. Brasil.

Endereço eletrónico: pfrodrigues@uea.edu.br 
dos metadados constituída pelas características de autoras/es, e respetivas filiações institucionais e geográficas e pelos títulos, resumos e palavras-chave. Os resultados mostram que os Estudos sobre as Mulheres, de Género e Feministas (EMGF) têm vindo a consolidar-se como um campo de estudos interdisciplinares e com uma tendência crescente para a investigação de caráter colaborativo. Ao longo das duas décadas analisadas, é possível encontrar a emergência de diferentes temáticas e conceções, e uma diversidade nos perfis e regimes de autoria. A publicação destes resultados do estudo bibliométrico realizado procura facilitar a definição dos futuros possíveis e desenvolvimento do campo dos EMGF, num contexto de diálogo nacional e internacional.

Palvaras-chave: bibliometria, revistas ex æquo e Faces de Eva, Estudos sobre as Mulheres / de Género / Feministas, Portugal, 1999-2019.

\begin{abstract}
'Studies on women' in Portugal after the Beijing Declaration - bibliometric study of ex æequo and Faces de Eva journals

In this article we present and discuss a set of results of a bibliometric study of the journals ex æquo and Faces de Eva. The metadata of 259 texts of Faces de Eva and 399 of ex æquo's, published between 1999 and 2019, were incorporated into a framework basis which included authors, their institutional and geographical affiliations and as well as all the titles, abstracts and keywords. The results show that Women's, Gender and Feminist Studies (WGFS) consolidated as a field of interdisciplinary studies, with a growing trend towards collaborative research. Over the two analysed decades different themes and concepts, and a diversity of profiles and regimes of authorship emerged. The publication of this set of results of the undertaken bibliometric study aims to facilitate a better definition of the possible future and development of the WGFS field, in a context of national and international dialogue.
\end{abstract}

Keywords: bibliometrics, journals ex æquo and Faces de Eva, Women/Gender/Feminist studies, Portugal, 1999-2019.

\begin{abstract}
Resumen
'Estudios sobre mujeres' en Portugal después de la Declaración de Beijing - estudio bibliométrico de las revistas ex æquo y Faces de Eva

En este artículo hacemos la primera presentación y discusión de un conjunto de resultados parciales del estudio bibliométrico de las revistas ex æquo y Faces de Eva. A partir de los 259 textos de Faces de Eva y 399 del ex æquo, publicados entre 1999 y 2019, se construye una base de metadatos, constituida por las características de los autores y autoras y sus respectivas filiaciones institucionales y geográficas y por títulos, resúmenes y palabras clave. Los resultados muestran que los Estudios de las Mujeres/de Género/Feministas (EMGF) parecen haberse consolidado como un campo de estudios interdisciplinario, con una tendencia creciente hacia la investigación colaborativa. A lo largo de las dos décadas analizadas, es posible encontrar la emergencia de diferentes temáticas y conceptos, y una diversidad de perfiles y regímenes de autoría. La publicación de estos resultados del estudio bibliométrico realizado busca facilitar la definición del posible futuro y el desarrollo del campo de los EMGF, en un contexto de diálogo nacional e internacional.
\end{abstract}

Palabras clave: bibliometría, revistas ex æquo y Faces de Eva, Estudios sobre Mujeres / de Género / Feministas, Portugal, 1999-2019. 


\section{Introdução}

As revistas ex æquo - Revista da Associação Portuguesa de Estudos sobre as Mulheres e Faces de Eva - Estudos sobre a Mulher (ex æquo e Faces de Eva, daqui em diante) têm representado nas últimas duas décadas em Portugal um lócus singular de afirmação e desenvolvimento dos «Estudos sobre as Mulheres» no país. É possível através da análise dos seus conteúdos, acompanhar, de algum modo, as abordagens, temáticas e modos de produção de conhecimento que têm alcançado visibilidade especialmente em Portugal. Não exclusivamente dedicadas à produção nacional, têm veiculado a discussão e reflexão que nos chega de outros países que se fazem presentes pela autoria diversificada em diferentes línguas (português, inglês, espanhol e francês). A realização de um estudo bibliométrico de ambas as revistas não tem como objetivo comparar as revistas para daí extrair conclusões sobre a mais-valia de qualquer uma delas, mas antes obter uma panorâmica da produção das duas revistas que claramente se reclamam da área dos «Estudos sobre as Mulheres», dos «Estudos de Género» ou dos «Estudos Feministas» (EMGF, de ora em diante). O objetivo é fazer uma cartografia da produção científica ao longo de duas décadas, entre 1999 e 2019, nesta área de estudos e analisar os temas que nela ressaltam, portanto, os conhecimentos que são veiculados e o perfil de quem os trabalha. A finalidade do exercício que faremos é descritiva, e não avaliativa.

Trata-se, no entanto, de uma contribuição que procura ir além de uma análise de métricas dos artigos publicados, possibilitando uma abordagem sobre o aprofundamento dos EMGF no desenvolvimento de um olhar epistemológico sobre as temáticas nestes campos. Tendo ambas publicado o seu primeiro número em 1999, pensamos poder tomar a sua produção como indicador do desenvolvimento deste campo científico em Portugal, no pós-Declaração de Pequim (1995) que inaugurou oficialmente a era das políticas de mainstreaming de género.

A revista ex æquo é uma publicação internacional, fundada por um grupo de académicas de várias universidades, reunidas na Associação Portuguesa de Estudos sobre as Mulheres (APEM) $)^{1}$ e tem como objetivo a contribuição para o desenvolvimento, visibilidade e legitimação do conhecimento científico no âmbito dos EMGF. A revista Faces de Eva², por sua vez, foi criada por uma equipa de investigação da Faculdade de Ciências Sociais e Humanas da Universidade Nova de Lisboa e tem por objetivo divulgar ensaios e resultados de pesquisas na área, bem como dar visibilidade a mulheres e associações com contributos relevantes e pouco conhecidos.

A realização do presente estudo consistiu na construção específica de metadados com o objetivo de quantificar informações sobre ambas as revistas e, deste modo, identificar padrões e tendências em temáticas, estilos de autoria e contextos

https:/ / exaequo.apem-estudos.org/

https://www.fcsh.unl.pt/facesdeeva/ 
disciplinares e geográficos de produção. A metodologia utilizada está baseada na bibliometria e cientometria que inspiraram a forma de obtenção dos dados e sua sistematização para uma análise qualificada. Com efeito o objetivo da cientometria é gerar uma caracterização quantitativa da atividade científica e medir desse modo o progresso dos campos disciplinares, isto é, interpretar os dados quantitativos (Santos e Kobashi 2009; Hernández-Pozo e Fernández-Rius 2013; Feldman e Sandoval 2018; Aksnes, Langfeldt, e Wouters 2019).

O presente trabalho consiste, assim, na apresentação de ambas as revistas, desde o seu primeiro lançamento em 1999 até ao momento presente (ex æquo 1999-2019 e Faces de Eva 1999-2018). As métricas sistematizadas servirão para, numa perspectiva feminista, proceder a uma análise crítica e compreensiva da dinâmica histórica e cultural em que a área de «Estudos sobre as Mulheres» se tem vindo a desenvolver, sem esquecer que as opções investigativas dos/as autores/as e as suas oportunidades de publicação poderão ser influenciadas por fatores de natureza diversa.

A realização de estudos desta natureza confere a possibilidade de demonstrarmos os processos de afirmação de uma área científica e de produzirmos conhecimento reflexivo que oriente novos percursos de investigação. No âmbito dos «Estudos sobre as Mulheres», essa dimensão da análise lança o olhar ainda para o que é singular na sua produção científica, com reflexos na prática sociopolítica, a partir de um posicionamento feminista que busca mudanças sociais de prossecução de maior igualdade entre mulheres e homens. A história dos feminismos tem, em cada lugar, a sua feição de resistência, luta e esperança por tais conquistas, na qual a ex æquo e a Faces de Eva também deixam o seu registo.

Por fim, esperamos com esse trabalho contribuir para a produção científica, divulgação e o desenvolvimento das pesquisas em «Estudos sobre as Mulheres», «Estudos de Género»e «Estudos Feministas». ${ }^{3}$

\section{Trajetórias da produção científica nos EMGF em Portugal}

Em meados dos anos 1980, Ana Nunes de Almeida (1986) questionava-nos sobre a presença das mulheres como investigadoras e como «objetos» de investigação evidenciando que não havia uma relação direta enquanto tema de pesquisa em «Estudos sobre as Mulheres», apesar do crescimento da presença de mulheres no âmbito das Ciências Sociais. A partir dos anos de 1990, os «Estudos sobre as Mulheres» passam a representar a expressão de um campo científico em cresci-

Este trabalho é o resultado do projeto «Produção e divulgação do conhecimento científico promotor da igualdade social entre mulheres e homens: da Academia à sociedade», financiado pela Comissão para a Cidadania e Igualdade de Género, em 2019. A coordenação esteve a cargo de Virgínia Ferreira, com a colaboração de Cristina C. Vieira e Maria João Silveirinha. 
mento e de maior visibilidade. Consequentemente à denúncia do androcentrismo dominante na produção científica (e.g, Smith 1987; Reason 1994) claramente refletido nos conteúdos, linguagem e instituições académicas e educativas, os vários ramos das ciências sociais e humanas (pese embora as suas especificidades e diferenças de prestígio) têm produzido conhecimentos conscientes do modo como as relações sociais de género atravessam os seus saberes e referências disciplinares.

É neste quadro que cresceu o interesse pela temática em pesquisas no campo das Ciências Sociais e Humanidades e, com isso, passaram a existir programas de pós-graduação stricto sensu e foram lançadas as revistas especializadas ex æquo e Faces de Eva no mesmo ano de 1999 (Ferreira 2001; Joaquim 2004; Barroso, Nico e Rodrigues 2011; Amâncio e Oliveira 2014; Vieira et al. 2016). É possível afirmar, nesse sentido, que o interesse crescente nessa área emerge ao mesmo tempo em que a problematização da desigualdade entre mulheres e homens se faz notar no mundo laboral e académico como campos reflexos da realidade social contemporânea.

O impacto dos feminismos nos discursos científicos (Ferreira 2001), não mais como questionamento, aponta para a trajetória irrevogável de novos caminhos na medida em que os «Estudos sobre as Mulheres» fazem eco nas mais diversas áreas do saber científico. Em Portugal, a denominação dessa área, de acordo com Teresa Joaquim $(2004,89)$ está alinhada com o desenvolvimento das Ciências Sociais e com o feminismo no país. É no âmbito das Ciências Sociais que o conceito de género emerge entre ambivalências e tensões académicas (Amâncio e Oliveira 2014) de modo que os anos de 1990 são marcados, principalmente, pela discussão epistemológica do projeto feminista, não apenas no campo científico, mas também no político. A Sociologia, em especial, tem um contributo preponderante nesse debate em Portugal, uma vez que é a área de estudos com um significativo aumento de pesquisas e diversidade de produção científica consolidando um campo específico como «sociologia do género» nas décadas recentes (Rodrigues 2009; Barroso, Nico, e Rodrigues 2011).

Se, como vimos, os Estudos sobre as Mulheres, como formação académica institucionalizada, começaram com o reconhecimento da ausência das mulheres nos textos canónicos e na investigação em geral, seriam as revistas científicas, com revisão por pares, que viriam a oferecer o espaço para publicação de trabalhos neste domínio, cristalizando, sem deixar de alargar, o núcleo teórico do campo e aumentando a sua legitimidade. Assim, e acompanhando o processo histórico e político-cultural destes estudos em Portugal, as revistas ex æquo e Faces de Eva demonstram o processo de construção e consolidação desse campo científico ultrapassando as fronteiras nacionais ao estarem indexadas em bases bibliométricas internacionais, como a SCIELO e a LATINDEX, no caso de ambas as revistas, e na SCOPUS no caso da ex æquo. As revistas, separadamente, têm evidenciado ao longo das suas publicações tal processo (Ferreira 2001; Joaquim 2004; Ferreira 2013; Vieira et al. 2016), mostrando como os «Estudos sobre as Mulheres», os feminismos, as questões de género, significam na trajetória da produção portuguesa 
um campo ainda em expansão, mas incontestavelmente não ignorado, seja pelos crescentes contributos das suas pesquisas, seja pelo reconhecimento científico das publicações, ou ainda pela resistência contra a marginalização das perspectivas feministas e de género na academia.

\section{Os estudos bibliométricos e cientométricos e o campo dos EMGF}

Os estudos que visam analisar livros e revistas vinculados à gestão de bibliotecas e de bases de dados, chamados de bibliometria (Santos e Kobashi 2009), estão comummente aliados aos estudos de cientometria, ramo da sociologia das ciências e da ciência da informação, que consistem na análise da produção, circulação e utilização de conhecimentos científicos no âmbito de uma dada área científica, com o objetivo de gerar uma caracterização quantitativa e objetiva da sua dinâmica (Santos e Kobashi 2009; Hernández-Pozo e Fernández-Rius 2013). A ampliação dessas abordagens tem gerado uma discussão crítica sobre as metodologias usadas e as finalidades desses estudos. Como ilustrativo dessa questão, o Manifesto Leiden aponta para o risco de se projetar uma análise focada nos dados em vez de uma avaliação qualitativa do conhecimento na área científica estudada que garanta boas práticas e interpretação das informações geradas, além de enfaticamente criticar a predominância de métricas, dentre outros critérios centralizados na língua inglesa (Hicks et al. 2015).

Refletindo sobre a realidade americana, e usando métodos essencialmente qualitativos, uma das primeiras autoras a estudar publicações científicas feministas foi Patrice McDermott (1994), para quem

estas revistas oferecem uma área rica a ser investigada, já que se dirigem a práticas e processos de publicação académica, moldando simultaneamente os parâmetros de um corpo disponível de investigação feminista e contribuindo para o avanço da academia dos estudos sobre mulheres. Consequentemente, as revistas fornecem um modelo para a compreensão da mediação da resistência feminista e da autoridade patriarcal na produção do conhecimento cultural (p. 1).

Também pioneiro no campo dos Estudos sobre as Mulheres, mas com recurso ao método bibliométrico, foi o trabalho de Cronin, Martinson e Davenport (1997) que analisaram a distribuição de género em três revistas entre 1970 e 1994 (Feminist Studies, Signs: Journal of Women in Culture and Society e Frontiers: A Journal of Women's Studies). Estudaram, além disso, os agradecimentos (acknowledgements e acknowledgees), em termos do reconhecimento de comunicação peer-interactive (PIC), e do tom (afetivo ou factual) com que eram escritos. Em termos de autoria, verificaram que $90 \%$ dos artigos eram assinados por mulheres, não deixando de comentar que tal produzia «uma irónica inversão da crítica frequentemente feita pelas académi- 
cas feministas às disciplinas tradicionalmente dominadas pelos homens, como a química, a ciência da computação e a economia» (Cronin, Martinson e Davenport 1997). Estudaram ainda os membros editoriais das três revistas, constatando uma incompatibilidade com os objetivos publicamente declarados das revistas.

Desde então, vários estudos usaram indicadores bibliométricos, como o número de artigos, padrões de citação, práticas de colaboração e o índice-h (ver, nomeadamente, Abramo, D’ Angelo, \& Caprasecca, 2009; Borrego, Barrios, Villarroya, \& Ollé, 2009; Geraci, Balsis, \& Busch, 2015).

Registem-se em particular alguns trabalhos no domínio dos Estudos sobre as Mulheres. Dehdarirad, Villarroya, e Borrios (2015) investigaram o desenvolvimento e o crescimento da literatura científica sobre as mulheres na ciência e no ensino superior usando indicadores bibliométricos, procurando depois analisar a correlação entre o Índice nacional de desigualdade de género e o desempenho em pesquisa. Söderlund e Madison (2015) analisaram as publicações de estudos de mulheres de autoria sueca entre 2000 e 2010 e propuseram várias hipóteses sobre a sua taxa de crescimento, impacto e outros indicadores bibliométricos. Situando-se no campo da literatura sobre violência de género publicada entre 1982 e 2013, Brihante et al. (2016) recorreram também ao mesmo método para tipificarem a investigação nesse domínio. Refira-se ainda o trabalho de Tsay e Li (2017) que, também no campo dos estudos sobre as mulheres, mapearam bibliometricamente a investigação entre 1900 e 2013, mostrando que a literatura publicada em revistas de estudos neste campo cresceu exponencialmente, com uma taxa de crescimento anual de 10,6\% ao longo de mais de um século.

Por fim, e mais recentemente, Yun, Lee e Ahn (2020) analisaram mais de cinquenta e sete mil artigos de estudos sobre as mulheres publicados entre 1975 e 2017, explorando a estrutura intelectual do campo com base em palavras-chave extraídas das publicações e nas referências citadas. Entre os seus resultados, a partir da análise de referências citadas mais de 100 vezes, verifica-se que não só os estudos sobre as mulheres, mas também os estudos da psicologia social formam a base intelectual dos estudos de mulheres citados na literatura científica. Concluiram também que as publicações por volta da década de 1990, como Gender Trouble de Judith Butler, Black Feminist Thought de Patricia Hill Collins e In a Different Voice de Carol Gilligan formaram um importante fundo de conhecimento para a área.

Santos e Kobashi (2009, 159) ressaltam que a atividade científica não se resume aos dados produzidos e muito menos se confunde com o que é o desenvolvimento do conhecimento cognitivo da ciência. Tais questões são pertinentes na nossa abordagem, uma vez que apresentamos uma produção científica dos «Estudos sobre as Mulheres» em duas revistas publicadas predominantemente em língua portuguesa nas últimas duas décadas. Inserida no panorama internacional atual da discussão e produção sobre essas temáticas, a produção do conhecimento científico dos EMGF apreende tal dimensão sem com isso perder de vista uma problemática epistemológica crítica a partir dos seus contextos. 
Como um campo profícuo para a análise da produção científica dos «Estudos sobre as Mulheres», a bibliometria e a cientometria possibilitam-nos uma abordagem que agrega ao aspecto quantitativo de autores, artigos, etc., uma análise cada vez mais aprofundada desde a perspectiva sociológica (Santos e Kobashi 2009). Assim, além de apreendermos as dimensões políticas e sociais da comunidade científica em torno dos EMGF (Hernández-Pozo e Fernández-Rius 2013), podemos percecionar a relevância para o tema no modo como a seleção de referências vai sendo feita nessa área de estudos (Aksnes, Langfeldt e Wouters 2019), entre outras considerações da análise.

\section{Corpus documental e análise dos dados}

Os resultados que apresentamos a seguir consistem na sistematização de um conjunto de 41 metadados (ver anexo) das revistas ex æquo e Faces de Eva referentes aos seus 20 anos de publicação, com a utilização do software de análise SPSS (Versão 22) e do Excel. ${ }^{4}$ Estes 41 metadados permitem-nos conhecer melhor a atividade de edição das revistas nas seguintes vertentes:

- perfis de quem nelas publicou, incluindo as áreas científicas e instituições de filiação;

- prevalência de temáticas e metodologias;

- prevalência e padrões de colaboração entre áreas disciplinares, institucionais e geográficas;

- padrões de referenciação bibliográfica (origens e suportes = países e tipo de publicações $=$ artigos, livros, atas, relatórios, etc.).

Nesta apresentação de resultados, analisamos algumas das informações das revistas em conjunto e outras em separado, pois a diferença de estrutura torna, em alguns momentos, inadequada uma análise comparativa entre ambas. Dessa forma, optamos por eventuais aproximações a fim de reconhecer os contributos em conjunto, respeitando as singularidades que apresentam e estão expressas nos seus modos particulares de apresentação e contextos institucionais em que se têm desenvolvido ao longo das últimas duas décadas.

Da ex æquo foram analisadas 39 edições, compreendendo o período de 1999 a 2019, e 399 artigos científicos publicados em dossiês temáticos e na secção «Estudos e Ensaios». Nestes 20 anos de publicação sistemática, a ex æquo tem mantido uma média regular de textos, cerca de 20 por ano, salvo no ano de 2002, quando a sétima edição - dedicada ao tema «Reformular os debates educacionais sobre a cidadania,

A Faces de Eva realizou um estudo bibliométrico cujos resultados foram publicados e analisados em Vieira et al. (2013). Nesse estudo foram analisadas todas as secções da revista: Estudos; Entrevistas; Pioneiras; (Auto)-retrato; Toponímia. Para o estudo de que aqui damos conta foi construída uma base de dados própria, que apenas se centrou na secção Estudos. 
agência e identidade das mulheres» - trouxe 18 trabalhos que, somados à sexta edição, publicada no mesmo ano, perfaz 29 artigos.

Já na Faces de Eva, o corpus trabalhado contempla 40 edições, no período de 1999 a 2018, com o total de 259 artigos e ensaios publicados nas secções «Estudos» e «Estado da Questão». As edições de Faces de Eva apresentam uma média mais regular, embora em menor número, de trabalhos por ano de publicação.

\section{Línguas usadas nas publicações}

A partir dos dados obtidos através das análises das revistas, verificamos a predominância da Língua Portuguesa como idioma dos artigos (ver gráfico 1).

\section{Gráfico 1.}

Idiomas publicados, 1999-2019

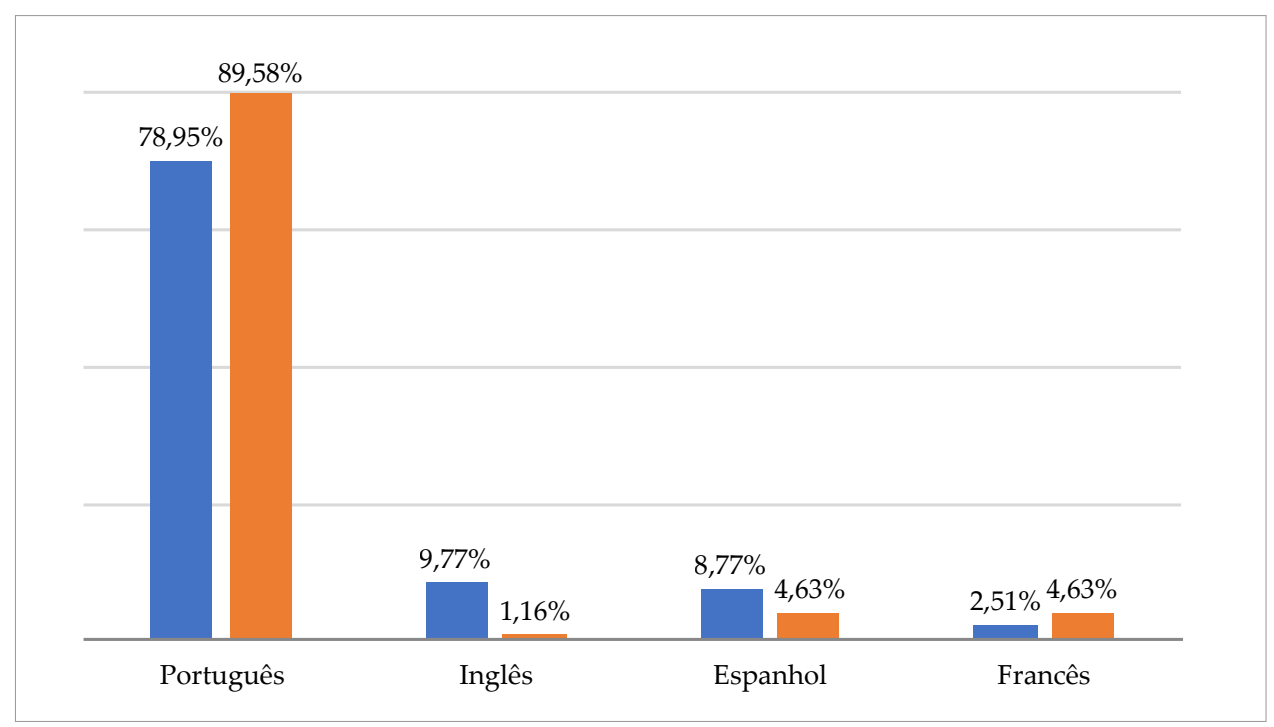

Observamos, no entanto, que as revistas se mantêm abertas a autoria proveniente de múltiplas nacionalidades e aceitação de textos em outros três idiomas, a saber: inglês, espanhol e francês. Essa pluralidade de idiomas está plasmada na publicação de trabalhos na língua de origem, já que apenas uma pequena parcela dos trabalhos é proveniente de traduções (5\% no caso da ex æquo e 2\% na Faces de Eva). Apenas autoras/es de renome internacional em EMGF têm originais traduzidos, ampliando o acesso a referências teóricas fundamentais nessa área. A desagregação por períodos de cinco anos mostra uma crescente inclusão de textos em outras línguas, em especial o Espanhol e o Inglês. 


\section{Autoria - Contextos institucionais e geográficos}

A observada predominância da Língua Portuguesa justifica-se pela presença maioritária de autoras/es filiadas/os em instituições sediadas em Portugal. O Brasil e os países africanos somam-se a Portugal nesta matéria. Como podemos verificar (ver gráfico 2) há, nas revistas, uma significativa diversidade de origens institucionais de diferentes geografias.

\section{Gráfico 2.}

País da Instituição da/o 1. ${ }^{\circ}$ Autor/a, 1999-2019

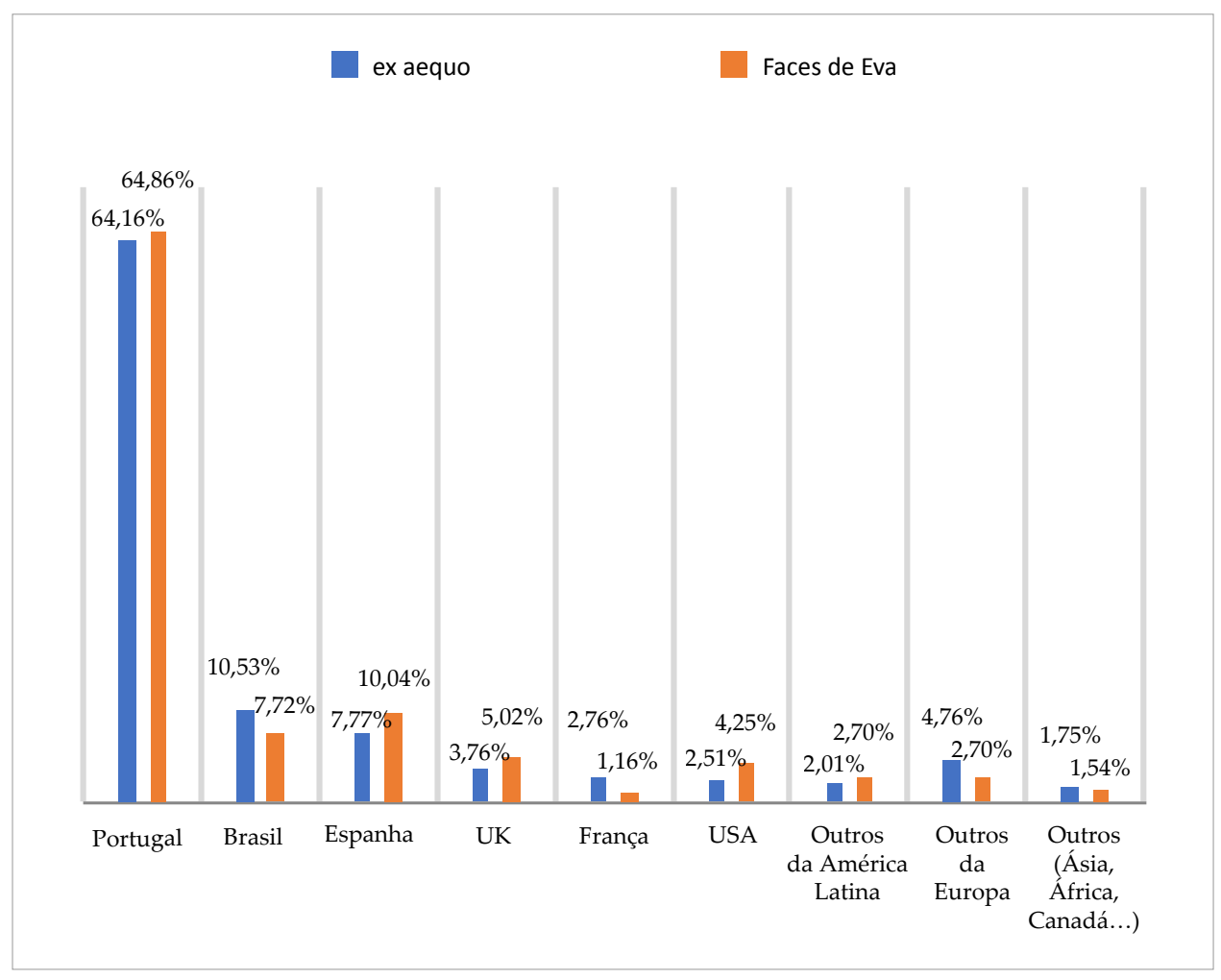

Em ambas as revistas há a clara predominância de autoras/es ligadas/os a instituições de ensino superior (ver gráficos $3 e$ 4), sendo na sua esmagadora maioria investigadoras a assinar os textos, o que reforça o reconhecimento das contribuições de mulheres na produção teórica e, por consequência, no contributo efetivo para o aprofundamento epistemológico nos EMGF no seio da academia. Com efeito, a quase totalidade dos textos publicados nas duas revistas provém do trabalho nas universidades: 86,7\%, no caso de ex æquo; 71,4\%, no caso da Faces de Eva. 
Gráfico 3.

ex æquo: Filiação institucional de 1. ${ }^{\circ}$ Autor/a, por sexo (1999-2019)

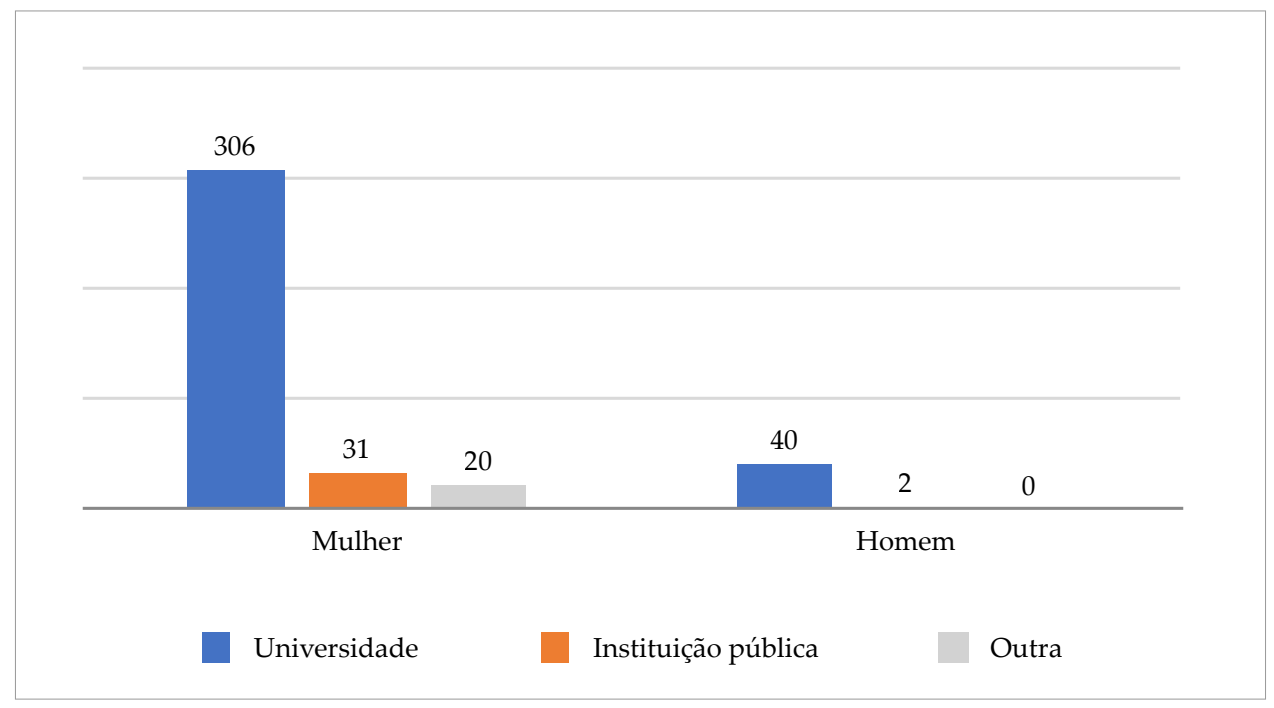

Gráfico 4.

Faces de Eva: Filiação institucional de 1. ${ }^{\circ}$ Autor/a, por sexo (1999-2019)

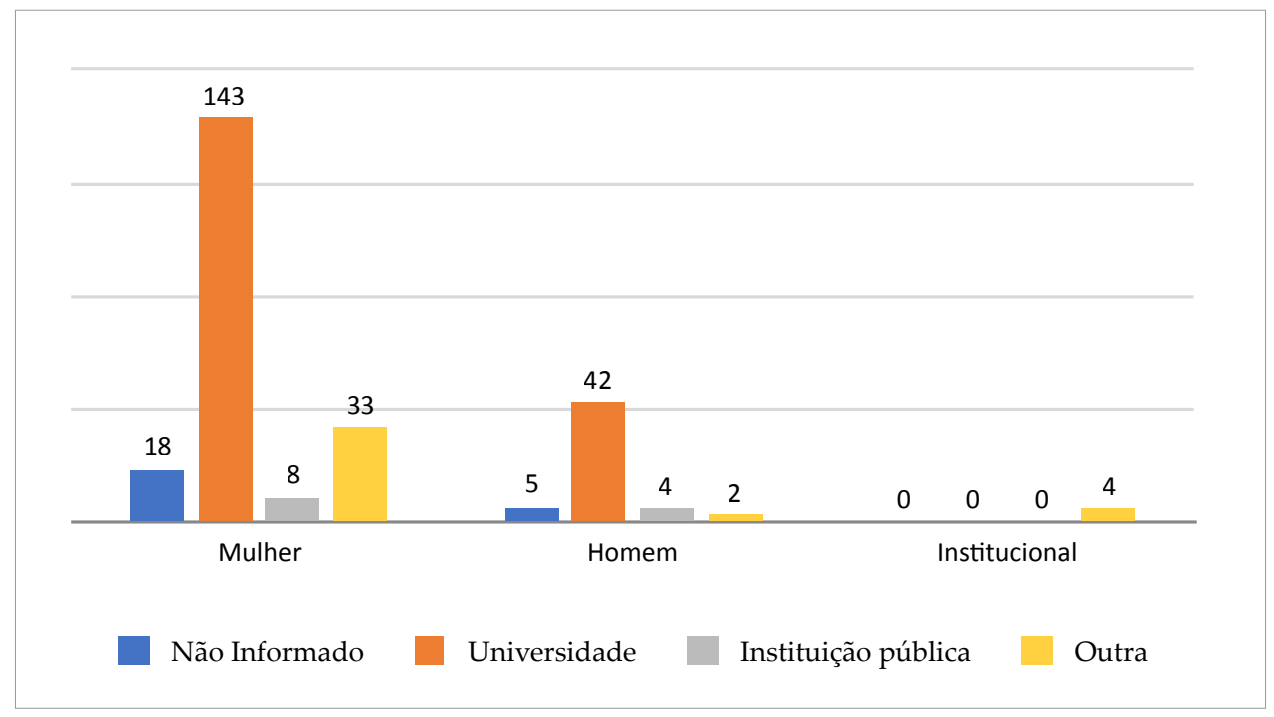

Dado que a revista Faces de Eva tem como particularidade a publicação da rubrica «Estado da Questão» - dedicada a apresentar «movimentos e organizações feministas, de apoio às mulheres, com grande participação feminina» (Vieira et al. 
2016, 40) - registamos a presença de assinatura institucional, o que mostra a valorização da representação coletiva dessas instituições (ver gráfico 4). Esta revista tem, portanto, um perfil menos estritamente académico.

As instituições de filiação também são diversas na sua área de atuação, já que a maior parte delas (ver gráfico 3) cobre diferentes domínios de pesquisa, demonstrando a abertura das revistas a instituições e investigadoras/es para além de centros e associações especializadas em EMGF. Ainda assim, as instituições especializadas correspondem a percentagens importantes na produção/divulgação de conhecimento científico nessa área. Ressalta, portanto, à vista que o propósito de mainstreaming de género tem alimentado as publicações, promovendo:

O diálogo com outras áreas também elas ainda emergentes, constitui um desafio para as áreas disciplinares e científicas constituídas, pela inovação dos temas e das abordagens, pelo risco de transgressão das fronteiras disciplinares, pelos novos estilos de escrita, pela própria emergência e articulação com outros pontos de partida» (Joaquim 2004, 92).

O facto de, no caso da ex æquo, quase metade dos artigos ter como primeira/o autor/a alguém com filiação numa instituição com investigação na área dos EMGF revela a crescente institucionalização desta área de estudos. Esta informação não deixa, contudo, de ser ambígua, porque esta filiação institucional pode não excluir a inscrição disciplinar dos/as autores/as nas disciplinas mais convencionais, como se pode constatar mais à frente (gráficos 14 e 15).

\section{Gráfico 5.}

Filiação em instituições com especialização em EMGF da/o $1^{\circ}$ autor/a, 1999-2019

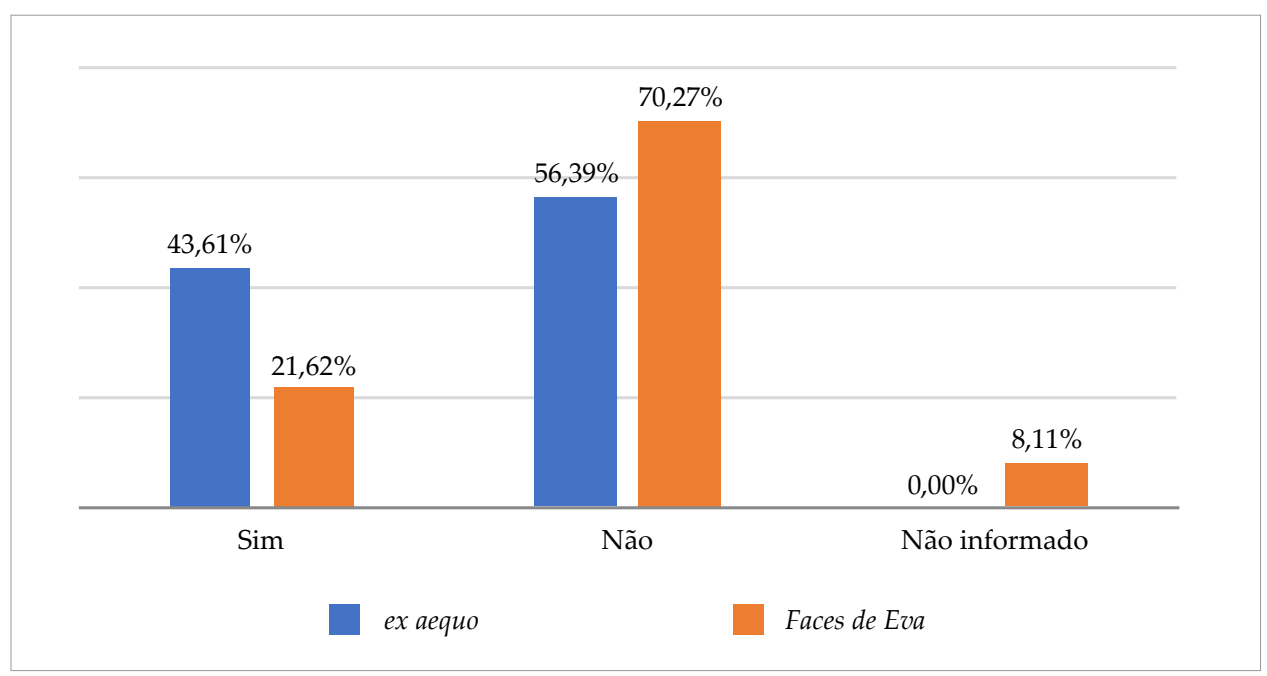


De notar que, enquanto parte do sistema de comunicação académica, o processo de publicação combina os elementos de recompensa, responsabilidade e reconhecimento (Cronin 1984; Henriksen 2016). A autoria é, neste processo, um elo essencial, já que é por ela que a/o investigador/a faz reivindicações de conhecimento, procurando, nomeadamente, demonstrar a originalidade e o valor do seu trabalho, responsabilizando-se por ele e procurando o reconhecimento dos seus pares.

Como seria de esperar, e como já se mencionou atrás, a maior parte dos textos em ambas as revista tem autoria feminina. A colaboração de autores tem-se verificado nestes 20 anos das publicações, com contributos especialmente no tema das sexualidades, temática em que os textos são assinados maioritariamente por homens.

\section{Fontes de inspiração mobilizadas}

A produção dos artigos demonstra uma diversidade de fontes bibliográficas nas duas revistas. Muitos trabalhos utilizam documentos históricos, notícias de imprensa, relatórios de organizações nacionais e internacionais, legislação, entre outros, como fontes relevantes para os respetivos estudos. Observamos ainda que, nos trabalhos com ampla consulta documental, a fundamentação teórica está baseada em livros, - verificando-se uma percentagem equivalente $(55 \%)$ em ambas as revistas (ver gráfico 9). Por outro lado, o peso dos artigos entre as fontes citadas ( $28 \%$ na ex æquo e $21 \%$ na Faces de Eva) indicia a preocupação de se consultarem fontes publicadas em revistas diversas, no sentido de uma busca de informação cada vez mais atualizada.

\section{Gráfico 6.}

Tipologia das referências bibliográficas por revista

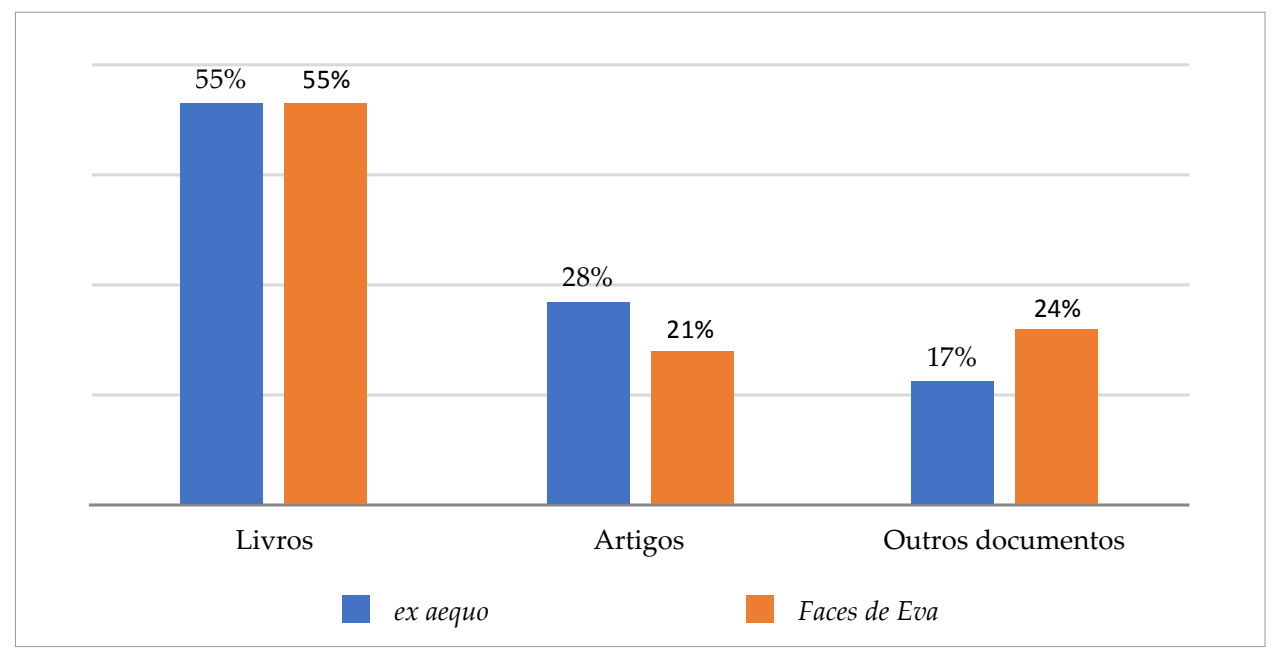


Tal reflete-se na média crescente de referências bibliográficas por artigo (ver gráfico 7). Ao observar os intervalos de cinco anos de publicação da ex æquo verificamos que no período de 1999 a 2004 a média era de 20,65 referências por artigo. Já nos últimos cinco anos, essa média subiu para 31,72. Na Faces de Eva, também se observa um acentuado crescimento do número de referências bibliográficas ao longo da década de 2010. ${ }^{5}$ No período 2015-2019, contabilizámos uma média de 22,5 referências bibliográficas por artigo.

\section{Gráfico 7.}

ex æquo - Número médio de referências bibliográficas por artigo, por quinquénio

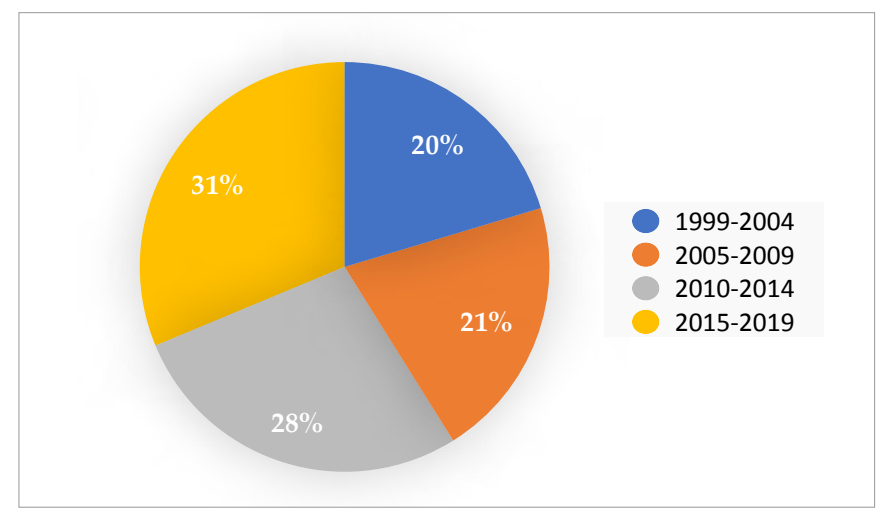

Sobre a frequência dos países de onde provêm os contributos teóricos e empíricos citados, verificamos que, na ex æquo, predominam referências a publicações de mesma nacionalidade da/o autor/a. Portugal é o país com maior presença nas citações, sendo preponderante em 147 dos 399 artigos analisados (ver gráfico 8). É importante observar ainda a forte presença de literatura de língua inglesa nas edições, pois identificamos 94 trabalhos em que as referências publicadas no Reino Unido ou Estados Unidos foram mais recorrentes.

5 No caso das publicações de Faces de Eva só foi possível fazer esta aferição, a partir do n. ${ }^{\circ}$ 32, devido a duas características da revista: 1) Em muitas edições, a revista adotava como norma a disposição das referências bibliográficas em notas de rodapé. Essa formatação impossibilitou a identificação fidedigna entre: obras citadas, indicações de leituras, comentários com novas referências, além da eventual repetição de uma mesma referência; 2) Em alguns artigos havia a indicação "para consultar bibliografia: www.fcshunl.pt/facesdeeva», no entanto, o link não esteve disponível para consulta durante o período de colheita e tratamento da informação. As referências aparecem de maneira normatizada na Faces de Eva somente a partir da edição 32 da revista, portanto, os dados recolhidos acerca dessa variável só nos permitem obter a média por artigo nos dois últimos quinquénios. 
Gráfico 8.

ex aequo - Países preponderantes nas referências bibliográficas

\section{Número de artigos}

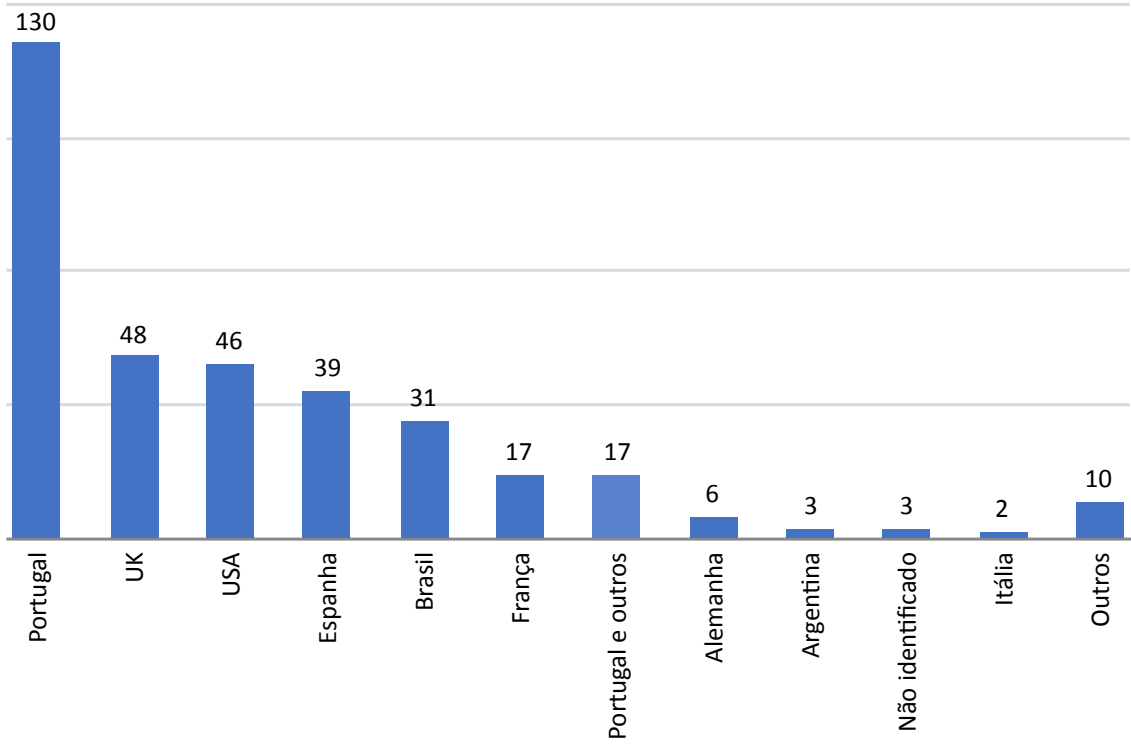

As estratégias de citação têm sido objeto de estudo, desde que Derek John de Solla Price, a partir do Institue for Scientific Information (ISI), começou, nos anos 70 do século passado, a analisar as relações estruturais das redes de referências e de citações (Santos e Kobashi 2009). ${ }^{6}$ Dos indicadores apurados relativamente às citações, queremos sublinhar o facto de a maior parte das fontes bibliográficas coincidirem na origem com os países das/os autoras/es. Esta é uma marca distintiva da ex æquo que mostra a relevância da sua missão - dar visibilidade aos EMGF em Portugal. É, por outro lado, interessante que não se verifique a tendência, observada em outros países periféricos ao sistema científico internacional, de as citações se centrarem em especial em publicações dos países centrais desse sistema, pelo

Esta análise partiu do Science Citation Index (SCI), criado por Eugene Garfield em 1961 (Aksnes et al. 2019, 2). Originalmente, esta base de dados bibliográfica foi construída principalmente para fins de recuperação de informações, para auxiliar na identificação de artigos relevantes nos enormes arquivos de literatura científica. Como subproduto, passou a ser usado para analisar quantitativamente a literatura científica. Desde a década de 1960, o SCI e outras bases de dados similares, agora incluídas online no Web of Science. Nesta base de dados, estão registadas as referências dos artigos indexados. Com base nisso, a cada artigo pode ser atribuído uma contagem de citações mostrando quantas vezes foi citado por artigos posteriores constantes na base de dados. 
facto de só estas serem consideradas fontes prestigiadas de conhecimento (Hoppen e Vanz 2020).

Esta prevalência de referências bibliográficas nacionais tem um reverso na escassa atenção dada às publicações das duas revistas, subsequentemente à desconsideração que o centro produtor de conhecimento dedica aos conhecimentos produzidos na periferia. Assim, a ex æquo contabiliza 151 citações no portal da SCIELO, no período 2008-2020 (11,6 em média por ano) e a Faces de Eva 20, contabilizadas no período 2014-2020 no mesmo portal (2,85 de média anual). ${ }^{7}$ Uma das razões para esta falta de reconhecimento prender-se-á, em parte, com o facto de o centro se expressar e ler essencialmente na língua inglesa. Esta consciência é cada vez mais determinante da opção pela publicação em língua inglesa, mais recorrente em ambas as revistas, ${ }^{8}$ mesmo quando os textos são de autoria nacional, o que não será um argumento suficiente para que o centro se interesse pelas problemáticas trabalhadas na periferia. O vaticínio feito por Caren Kaplan, por altura da criação das duas revistas, de que a receção do conhecimento tinha que seguir orientação diferente da lógica preponderante, isto é, «from the West to the rest», continua por concretizar (Kaplan 1994 apud Pesole 2012, § 62).

Assim como a nacionalidade da autoria se refletiu nos países das referências, verificamos relação semelhante entre a localização dos objetos de estudo e o país de filiação da/o primeiro/a autor/a. Portugal é objeto de estudo em $43 \%$ dos artigos publicados na ex æquo (ver gráfico 9) e em $54 \%$ na Faces de Eva (ver gráfico 10). É importante destacar a quantidade de trabalhos de reflexão teórica em ambas as revistas (22\% na ex æquo e 15\% na Faces de Eva), ou seja, sem a análise de um objeto empírico específico. Entendemos esse dado como reflexo da crescente preocupação epistemológica dos EMGF nas últimas décadas.

A observação situada dos/as autores/as, no entanto, não limita o campo de análise, uma vez que há vários estudos comparativos em ambas as revistas entre diferentes países (8\% ex æquo e $6 \%$ na Faces de Eva), tendo ainda a comparação com Portugal (43\% ex æquo e $54 \%$ na Faces de Eva) a maior incidência.

$7 \quad$ No caso da ex æquo, 50\% são autocitações, percentagem que aumenta para 75\%, no caso da Faces de Eva (respetivamente em http://statbiblio.scielo.org//stat biblio/index.php?no=09.xml\& state=09\&lang=pt\&issn=0874-5560 e http:/ / www.scielo.mec.pt/statjournal.php?lang=pt\&issn $=0874-6885 \&$ collection $=$ prt, consultadas no dia 1 de dezembro de 2020 .

$8 \quad$ Na ex æquo a abertura à publicação em inglês, francês e espanhol ocorreu em 2005 (Pinto 2009, 67). 


\section{Gráfico 9.}

ex æquo - Países mais pesquisados

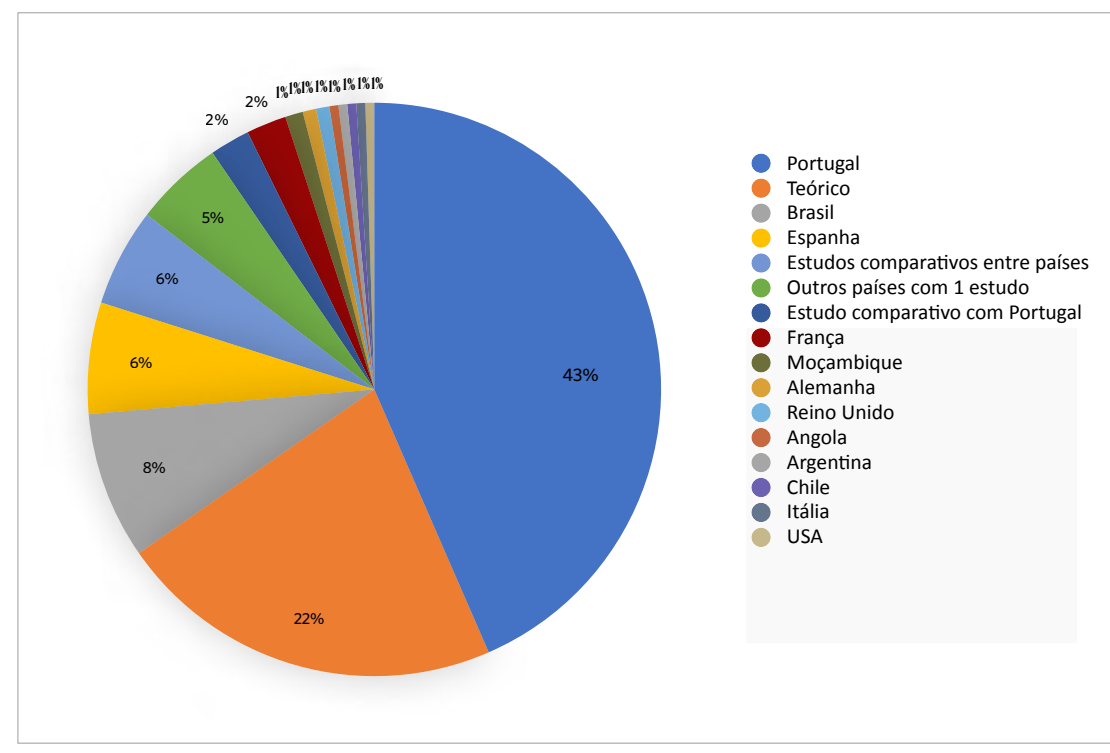

Relativamente à autoria, identificamos diversidade nos artigos das duas revistas. $\mathrm{Na}$ ex æquo, 86\% dos/as autores/as aparecem com um trabalho apenas em todo o histórico das edições e na Faces de Eva, a percentagem é de 92\%. Esses números demonstram como as revistas têm constituído oportunidades para diferentes autoras/es publicarem os seus trabalhos.

A pluralidade verifica-se também em relação às coautorias. Ao observamos a relação entre o número de autoras/es por artigo por períodos das revistas, percebemos como tem sido crescente a presença de trabalhos provenientes de trabalho colaborativo. Verificamos que, na ex æquo (ver gráfico 11), os números com trabalhos assinados por uma pessoa reduziram de 89 no período de 1999 a 2004 para 41 no período mais recente, de 2015 a 2019. Na Faces de Eva (ver gráfico 12), a redução foi ainda mais significativa - de 83 no primeiro período para 35 de 2015 a $2018 .{ }^{9}$

Em nosso entender, esta crescente coautoria tem por base um conjunto de factores. Em primeiro lugar, será resultado da pressão para publicar a que assistimos em todas as áreas científicas e desde que começaram a disseminar-se modelos de desempenho científico assentes em medidas bibliométricas. De algum modo, pode dizer-se que assistimos a um efeito de spill over da cultura de publicação das ciências da vida e da natureza, ou experimentais, se preferirmos, para as restantes

A edição de 2019 ainda não havia sido publicada até à realização desta pesquisa, finalizada em agosto de 2019. 
ciências, não experimentais. Enquanto nestas predominava a autoria isolada, naquelas sempre houve a prática de publicar em coautoria numerosa e diversa em termos das categorias académicas e até de instituições e geografias envolvidas.

\section{Gráfico 10.}

Faces de Eva - Países mais pesquisados

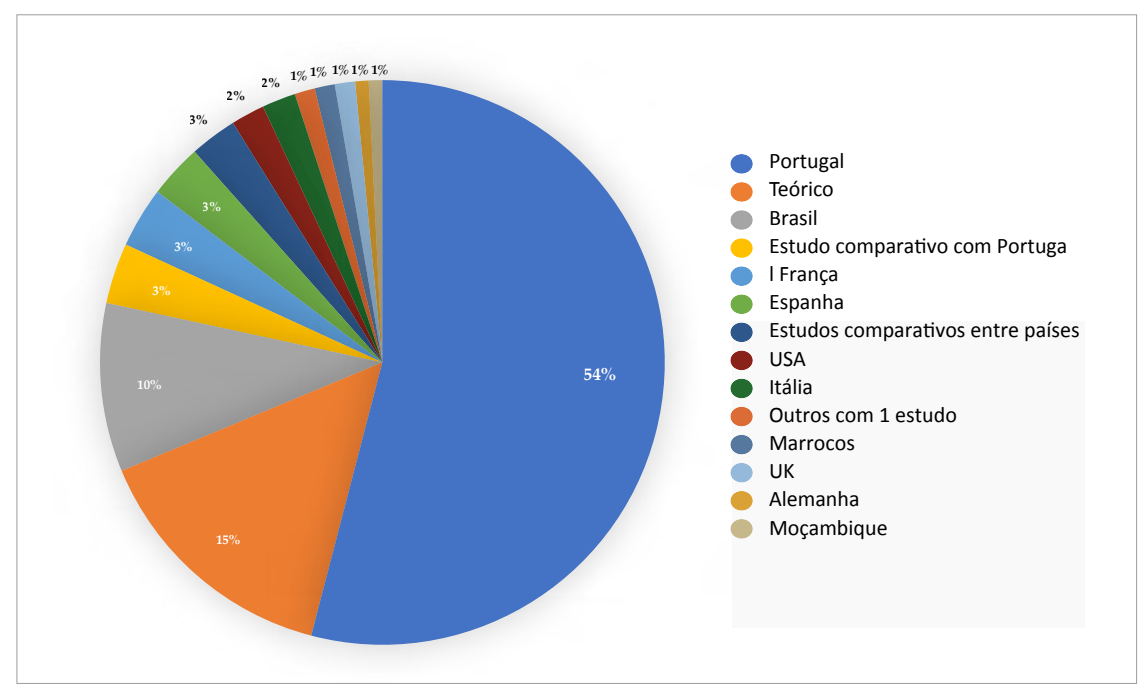

Outro factor explicativo residirá na crescente natureza formal e institucional que preside ao trabalho colaborativo existente neste campo dos EMGF. Daí surgirem cada vez mais textos assinados por orientadoras/es e orientandas/os, elaborados no quadro de dissertações de programas de pós-graduação de mestrado ou doutoramento em EMGF. O que era antes considerada uma colaboração informal (neste campo, como em outros), é agora considerada uma colaboração formal, pela qual as/os orientadoras/es dos trabalhos de investigação esperam, pela coautoria, formalizar a sua contribuição, quando antes esse seu contributo seria muito pouco reconhecido (Henriksen, 2016). Estas coautorias que envolvem orientandas/os e orientadoras/es têm uma natureza hierárquica, mais comum no campo das EMGF, segundo o estudo comparativo de Madison et al. (2018) e avaliado negativamente, uma vez que não decorrem de trabalho colaborativo entre pares.

Esse pode ser, claramente, um indicador de maior institucionalização dos EMGF. Com efeito, por altura do aparecimento das revistas não existia a pressão para publicar artigos enquanto se desenvolvia a pesquisa a submeter em provas de mestrado e doutoramento, nas quais era suposto apresentar trabalho original. Hoje em dia, em muitas universidades é possível defender provas de doutoramento com base em 3 ou 4 artigos publicados, onde nem sempre a pessoa que obtém o grau aparece como primeira autora dos artigos integrados na tese. 
Gráfico 11.

ex æquo - Número de autoras/es por artigo, por quinquénio

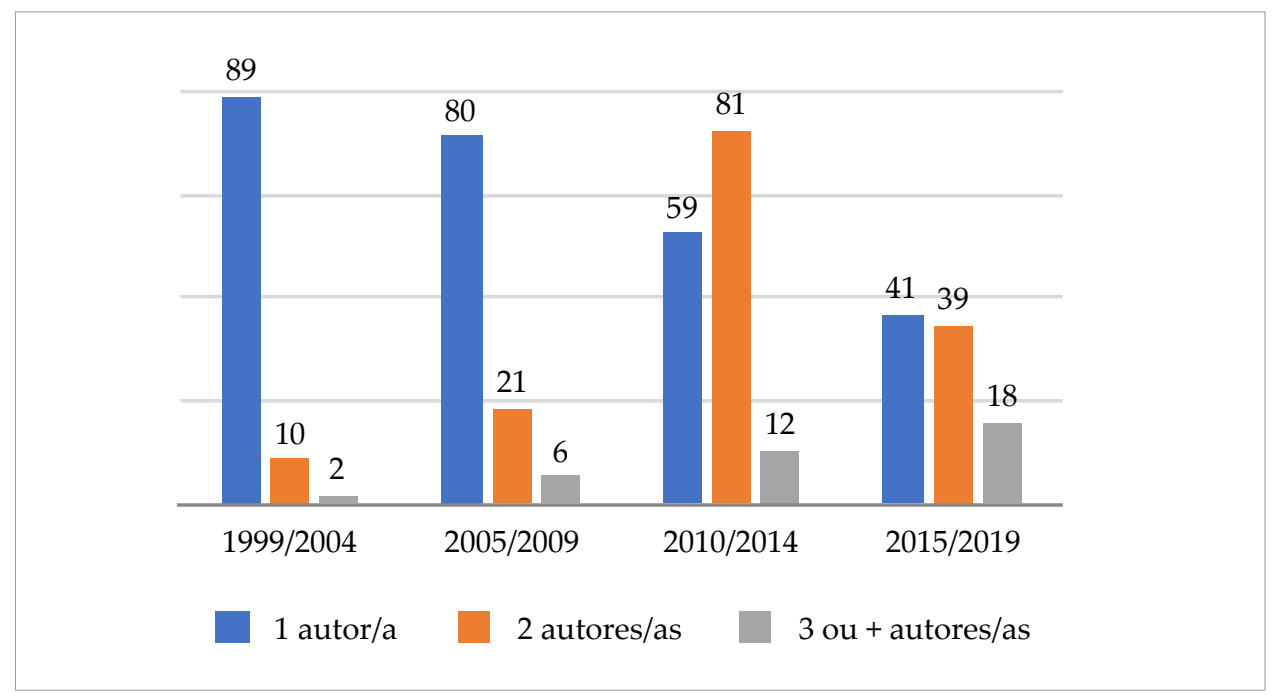

Gráfico 12.

Faces de Eva - Número de autoras/es por artigo, por quinquénio

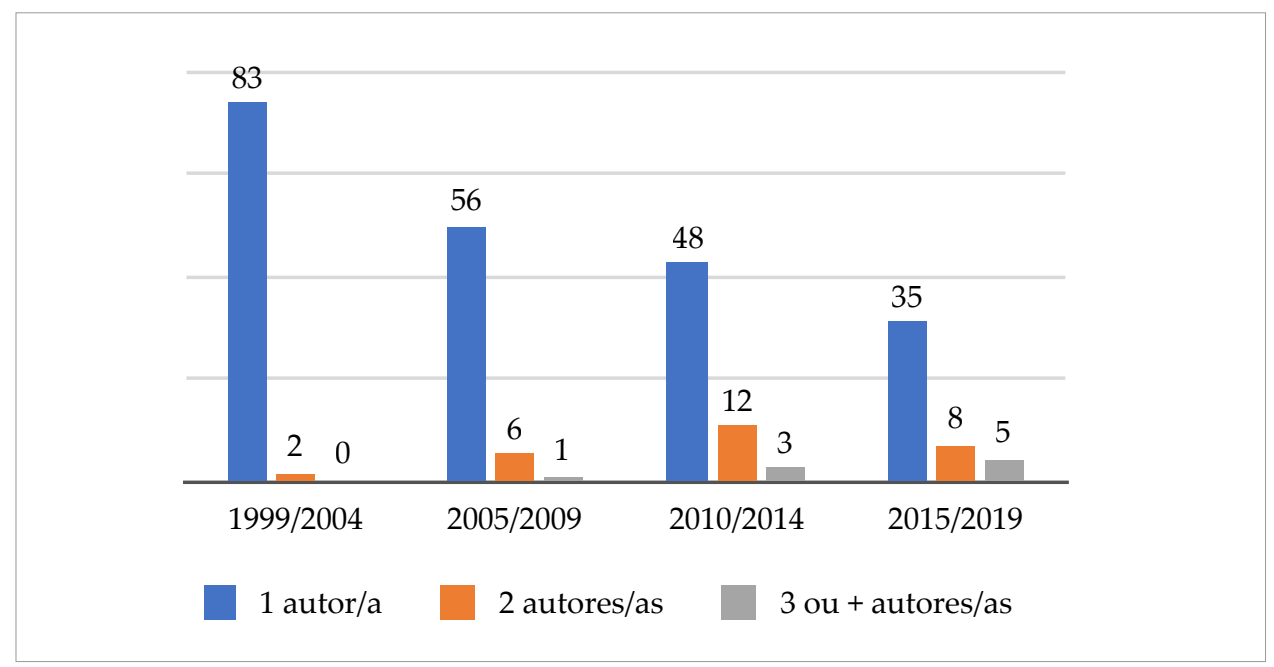

O aumento das coautorias é ainda reflexo da crescente prevalência de projetos financiados que envolvem equipas da mesma área e de estudos provenientes de áreas das ciências sociais que envolvem a participação de investigadoras/es de outros campos do saber que, em geral, exigem uma diversidade de especialidades 
para produzir e analisar quantidades importantes de informação estatística (ou de outra natureza), o que não acontece nas humanidades. Nestas, é mais comum um trabalho mais individual, de recorte teórico, com base sobretudo em metodologias qualitativas (Hoppen \& Vanz 2020, 11). Cumulativamente, começam também a surgir mais frequentemente artigos produzidos nas áreas da saúde (psiquiatria; psicologia; neurociências) que requerem a participação de investigadores/as em EMGF, em virtude da necessária análise interseccional dos temas que fazem parte das respetivas agendas científicas.

A presença de mais textos em coautoria resulta também no aumento da presença feminina nas publicações, dado que $87 \%$ da coautoria, quer na ex æquo, quer na Faces de Eva, é composta por mulheres, apesar desta percentagem representar números absolutos distintos (166 mulheres na ex æquo e 46 na Faces de Eva). A participação masculina na coautoria também apresenta índices idênticos nas revistas $(13 \%)$, mas traduz a presença de 25 coautores na ex æquo e 7 na Faces de Eva.

\section{Recurso à linguagem inclusiva}

Gráfico 13.

ex æquo - Tipo de linguagem utilizada, por quinquénio

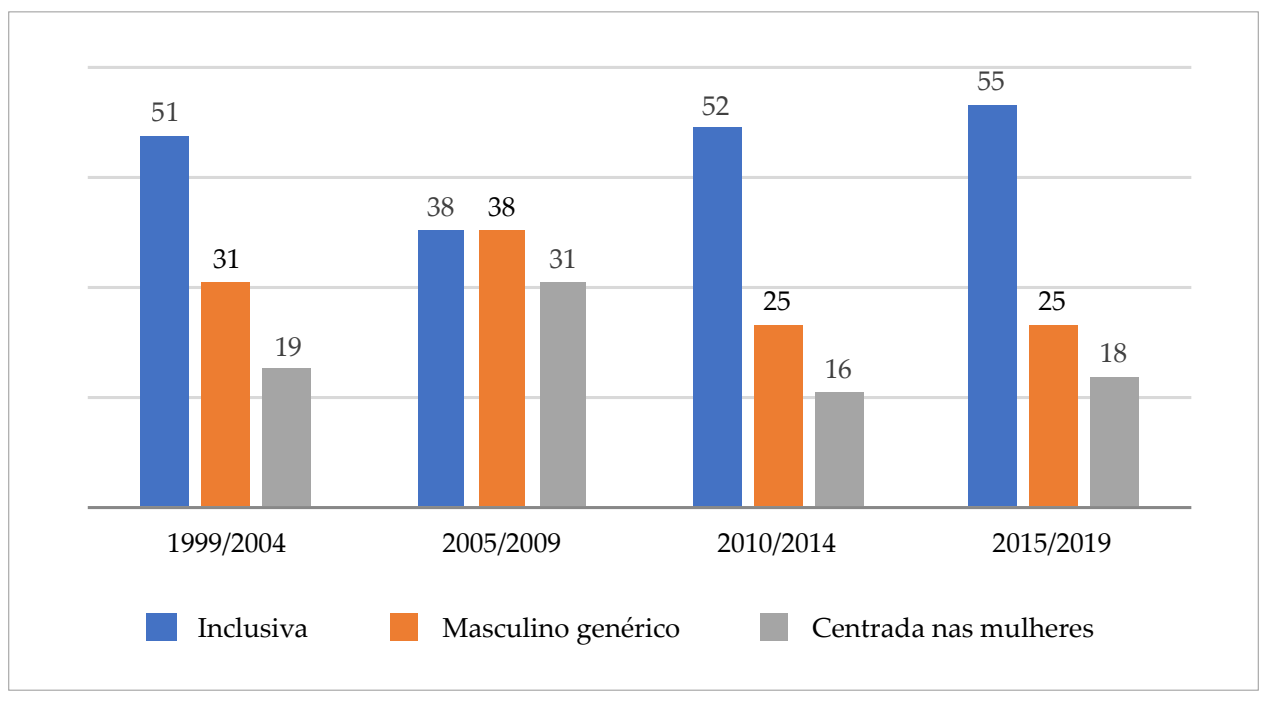

Ao decompor a análise dos dados em períodos de cinco anos, percebemos a preocupação dos/as autores/as e coautores/as com a linguagem adotada na escrita dos trabalhos publicados na ex æquo. Desde as suas primeiras edições, a linguagem inclusiva, ou seja, com a flexão de género evidente como forma de combate ao 
sexismo da linguagem (Abranches 2009), tem sido o estilo maioritário de expressão para autores/as e coautores/as. Na Faces de Eva, a linguagem baseada no masculino genérico apresenta maiores ocorrências em diferentes períodos de sua história, mostrando assim que a problematização da linguagem permanece restrita a poucos/as autores/as.

O registo da linguagem leva-nos a perceber que também os conceitos importantes dos EMGF que são trabalhados se vão alterando ao longo dos 20 anos das revistas, talvez fruto das recomendações internacionais, como as do Conselho da Europa (1990; 2007), sobre a eliminação do sexismo na linguagem, e da importância crescente que as questões da linguagem inclusiva têm assumido nas políticas públicas e nos compromissos transnacionais ratificados por Portugal e outros países (ex: CEDAW).

\section{Gráfico 14.}

Faces de Eva - Tipo de linguagem utilizada, por quinquénio

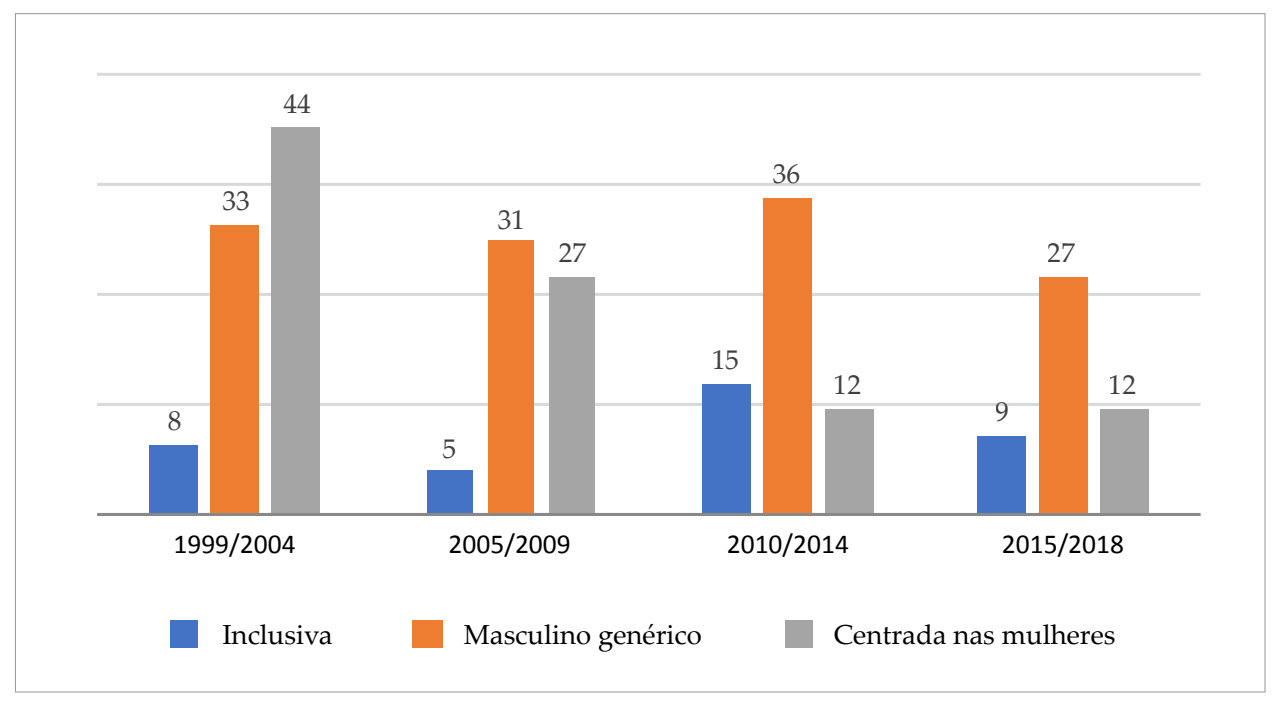

\section{Quadros conceituais e disciplinares prevalecentes}

No caso da ex æquo (ver gráfico 15), fica evidente a expressão crescente de preocupações, posições e reflexões feministas e dos feminismos nos três primeiros períodos da publicação. Apenas no período mais recente, de 2015 a 2019, observamos a redução dos termos «feminismos» e «feministas» nos artigos. Por outro lado, esse movimento decrescente pode estar relacionado com o salto verificado na presença do conceito de género e de termos derivados, como genderizado, que 
passou a aparecer nada menos que 43,64 vezes por trabalho, em média, nas edições publicadas de 2015 a 2019.

A crescente utilização do conceito de género, em alguns casos, estará associada à procura de maior legitimidade científica, uma hipótese aventada em outros estudos produzidos, nomeadamente, sobre o Brasil, como, por exemplo, nos referenciados por Hoppen e Vanz (2020). Não deixa de ser inquietante esta tendência para recorrer ao potencial efeito «branqueador» imputado por algumas abordagens ao conceito de género, enquanto distanciamento de explicações biológicas. De qualquer modo, a inquietação decorre da substituição que é feita - desaparecem os termos feminista e feminismo para sobressair os de género e de LGBTI, enquanto o emprego de masculinidade e de feminilidade praticamente não sofre alterações. Há claramente nesta evolução um acompanhamento das agendas dos movimentos feministas ao longo das duas últimas décadas.

Tendência semelhante foi verificada no crescimento dos trabalhos relacionados com as sexualidades e que abordam, entre outras, as questões decorrentes da crescente visibilidade que as problemáticas suscitadas pelas identidades LGBTI têm suscitado. Entre 1999 e 2004, esses termos apareciam apenas 0,1 vezes, em média, nos artigos. Já nas últimas edições da revista, a média por artigo passou a ser de 7,8 ocorrências.

\section{Gráfico 15.}

ex æquo - Número médio de vezes que os conceitos são usados, por artigo, por quinquénio

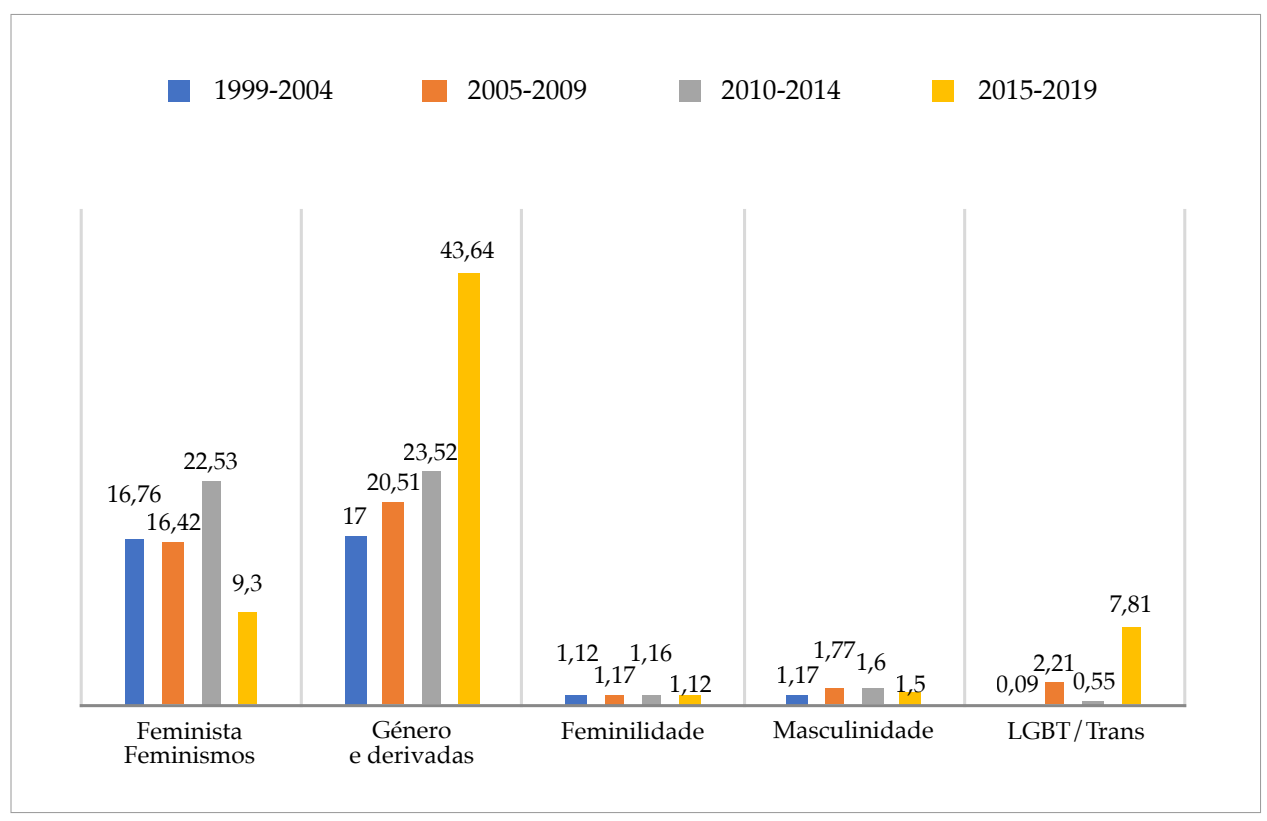


Com relação à Faces de Eva, é importante ressalvar que os dados obtidos durante o levantamento não nos permitem fazer uma análise comparável, pois tivemos acesso à versão digital da revista apenas a partir da $32^{a}$ edição, disponível no endereço da biblioteca eletrónica SCIELO. Dessa maneira, nas primeiras 31 edições, trabalhamos com edições impressas das revistas e, portanto, tivemos de restringir a pesquisa aos títulos, resumos e palavras-chave, sendo que estes últimos também não constavam em todos os trabalhos, pois verificamos que a formatação da revista passou por mudanças ao longo dos seus 20 anos de história e, nas primeiras edições, a formatação não previa resumos e palavras-chave, por exemplo. Essas limitações justificam o escasso número de vezes em que os conceitos são aqui contabilizados e as grandes diferenças entre os dois primeiros quinquénios e os dois últimos.

\section{Gráfico 16.}

Faces de Eva - Número médio de vezes que os conceitos são usados, por artigo, por quinquénio

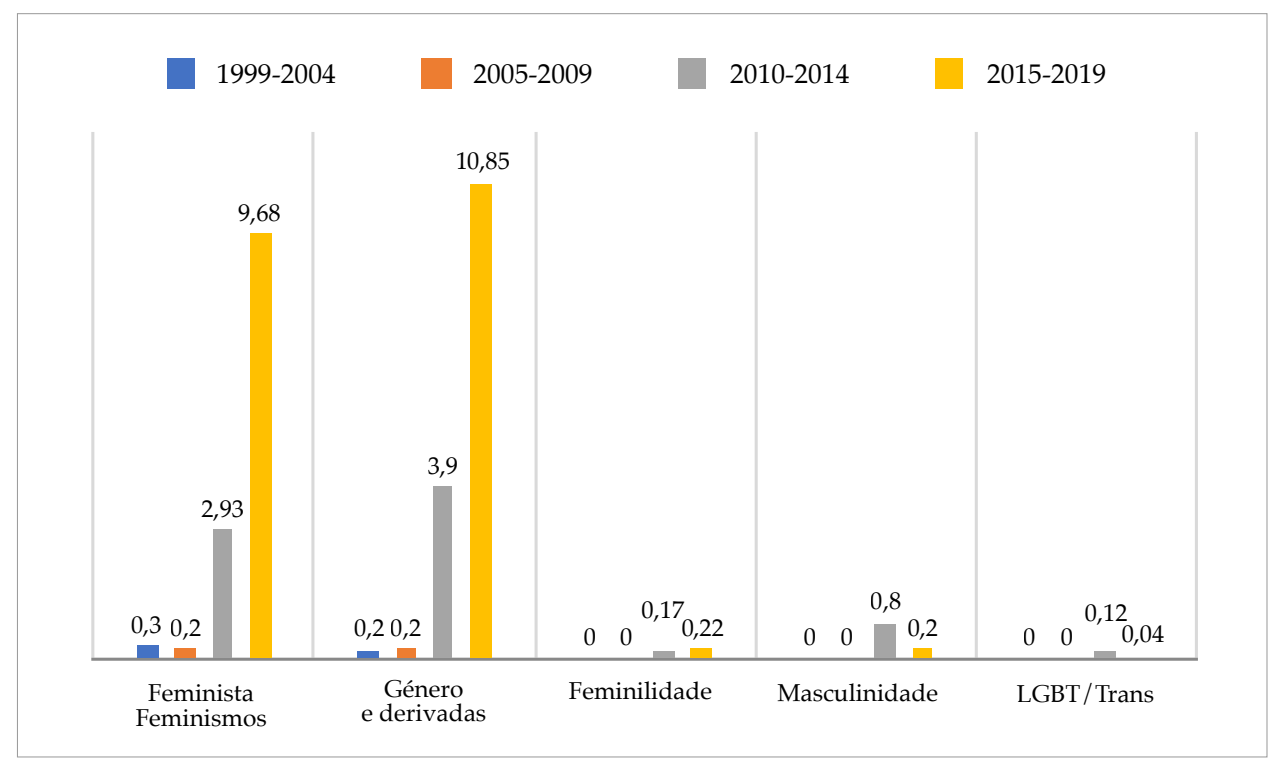

Outra variável obtida no levantamento e aqui analisada por período é a área disciplinar da/o $1^{\circ}$ autor/a. A partir dos dados podemos compreender dois movimentos simultâneos nas revistas: de um lado percebemos a consolidação de áreas enquanto locus de debate para os EMGF, como a Sociologia e as Ciências da Educação na ex æquo (ver gráfico 17) e a História e os Estudos Literários/Linguísticos na Faces de Eva (ver gráfico 18); mas do outro, a análise por períodos expõe o crescente interesse de outras áreas. Neste movimento, observamos os ganhos alcançados pela Psicologia e os Estudos Culturais e da Comunicação na ex æquo e da Sociologia na Faces de Eva. 


\section{Gráfico 17.}

ex æquo - Número de artigos por área disciplinar, por quinquénio

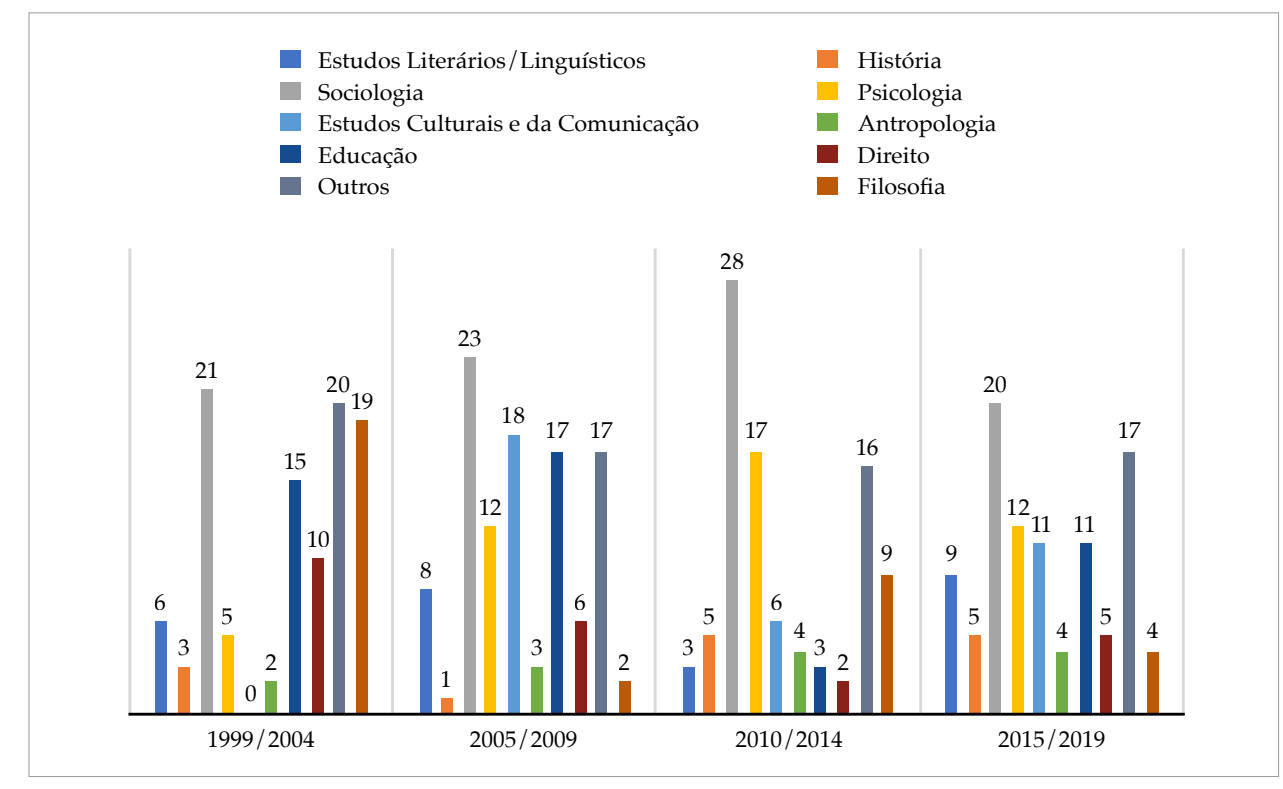

Gráfico 18.

Faces de Eva - Número de artigos por área disciplinar, por quinquénio

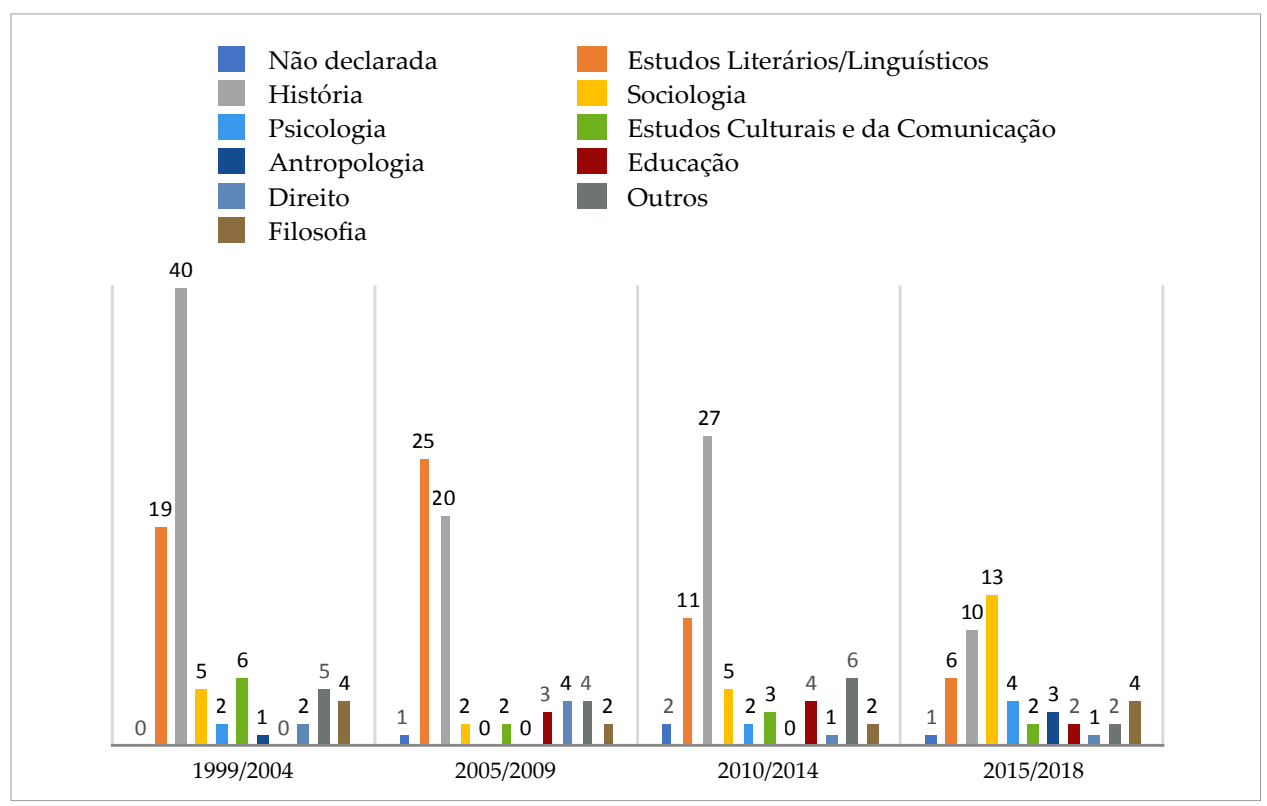


A maior presença de determinadas áreas disciplinares incide diretamente sobre as metodologias mais adotadas nos estudos. Além disso, indica os processos de formulação e consolidação de diferentes perspectivas de trabalho nas Ciências Humanas e Sociais.

\section{Metodologias e temáticas mais frequentes}

Nas duas revistas, a publicação de ensaios (ver gráficos 19 e 20) apresenta números expressivos nos diferentes períodos, mas com relativa redução nas edições mais recentes, sobretudo na ex æquo. Esse dado remete-nos para a constante atualização da reflexão epistemológica nos EMGF, mas também às dificuldades de acesso aos meios materiais e institucionais para que pesquisas de campo nessa área fossem realizadas com maior fôlego nos primeiros cinco anos das publicações. Ao observarmos o crescimento de metodologias mistas, ou seja, realizadas a partir da combinação de métodos quantitativos e qualitativos, verificamos a alteração gradual no cenário da ex æquo onde observamos mais claramente a utilização de diferentes procedimentos metodológicos.

Na Faces de Eva, identificamos, além da forte presença dos ensaios em níveis semelhantes em todos os períodos, como já referimos, pesquisas com metodologia documental e análise literária com picos significativos em diferentes períodos de publicação - análise documental entre 1999-2004 e análise literária entre 2005-2009. Atribuímos a esta especificidade a presença constante de autoras/es da História e dos Estudos Literários/Linguísticos ao longo das edições de Faces de Eva, sendo uma revista mais voltada para essas áreas.

As metodologias qualitativas de produção e análise de dados têm prevalecido nos EMGF e também nas revistas em análise, como é notório nos dois gráficos que se seguem (19 e 20). Para o exame e descrição das informações trabalhadas neste campo usaram-se as expressões encontradas nas publicações, para mencionar as estratégias de investigação explicitadas pelas/os autoras/es, ainda que se saiba que as mesmas não representam categorizações metodológicas mutuamente exclusivas. Além disso, como pode observar-se nos gráficos 19 e 20, ora se indicam designs de investigação (ex: inquéritos; estudos de caso), ora técnicas de recolha de dados (ex: entrevistas), ora ainda técnicas de análise de dados (ex: estatísticas; análise do discurso).

Essa estratégia metodológica tem-lhes acarretado a crítica que, do ponto de vista positivista, tem sido apontado a estas metodologias - acusados de não serem exatamente académicos, excessivamente ideológicos e teóricos, se basearem em metodologias pobres, por fazerem um limitado uso e análise de dados empíricos e centrarem o seu foco em conceitos abstratos como "estruturas sociais" ou por assumirem uma «ordem do poder de género» (Pereira 2012). Esse tipo de conclusões estão enunciadas em, entre outros, o estudo de Madison e Söderlund (2018), 
que, com base na análise de artigos em revistas de EMGF e de outras abordagens, publicadas na Suécia, levou as autoras a decretar que: «gender studies can do better». Estas críticas derivam claramente da natureza contextual da informação produzida por métodos qualitativos, da orientação mais local das pesquisas, do papel central desempenhado por quem conduz as pesquisas e dos desafios da falta de estruturação das técnicas (Bergano e Vieira 2020). São também críticas decorrentes de análises filiadas em paradigmas objetivistas prevalecentes nas ciências experimentais, e que ignoram as diferenças entre os diversos campos científicos, tal como é denunciado no comentário àquele estudo de Nina Lykke (2018). A validade externa não constitui, com efeito, a preocupação central na investigação qualitativa, pois o objetivo principal não é a generalização dos resultados, mas a validade interna. Neste caso, os critérios de qualidade que devem ser seguidos devem atender à credibilidade das conclusões extraídas, à adequação das respostas dadas às questões de investigação formuladas e à legitimidade dos processos metodológicos mobilizados (Vieira 1999). É por isso que, à metodologia bibliométrica, priorizamos o processo de peer review, anónimo de preferência, apesar das limitações de subjetividade, arbitrariedade e morosidade que lhe são apontadas (Aksnes, Langfeldt, \& Wouters 2019).

Gráfico 19.

ex æquo - Metodologias usadas, por quinquénio

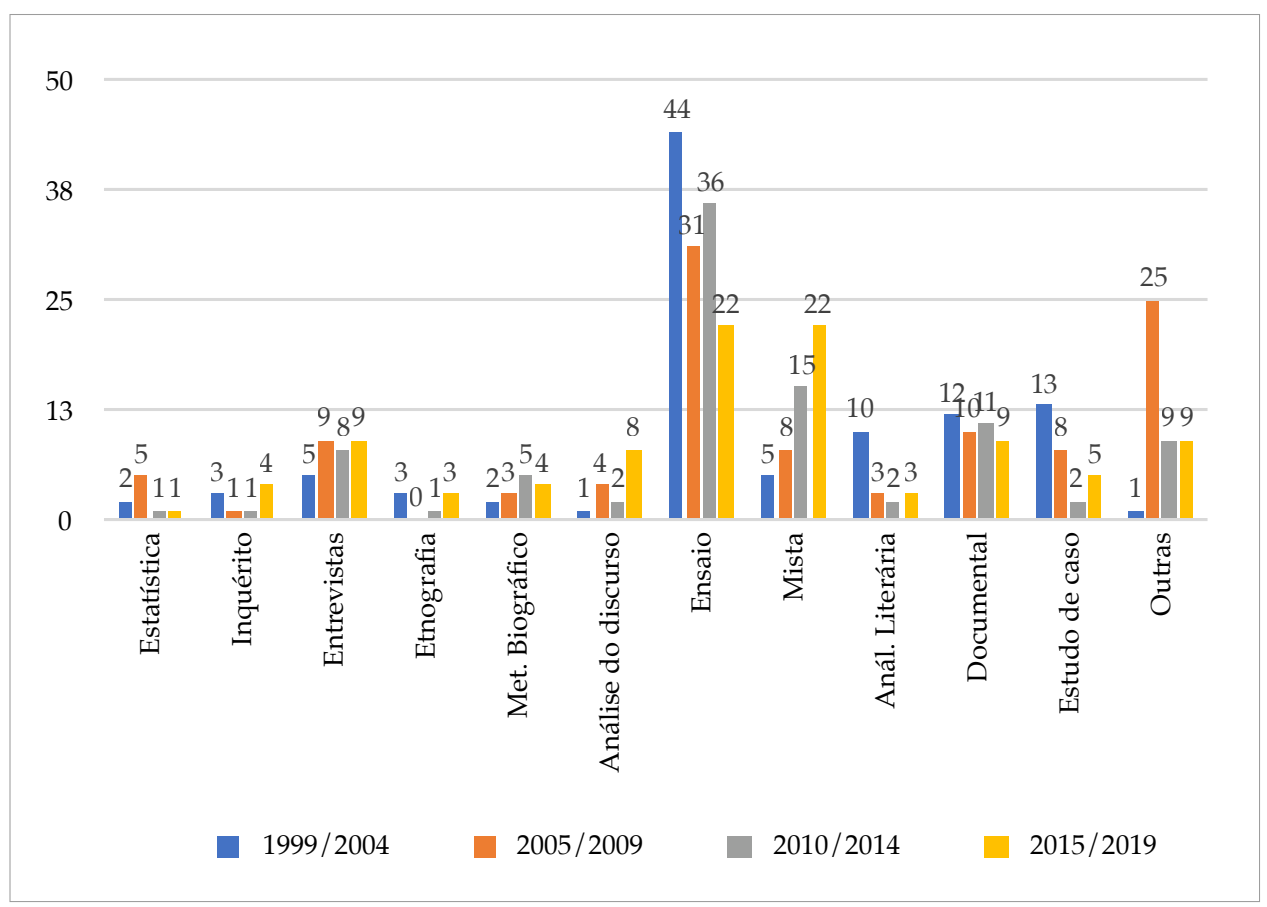


Para além da análise de indicadores quantitativos a partir dos dados recolhidos no corpus documental que serviu de base para este estudo, foi possível fazer uma análise temática dos assuntos tratados na ex æquo. Ficará para outra publicação a exploração dos temas identificados, que foram posteriormente agrupados em categorias conceptuais mais abrangentes..$^{10}$ No gráfico 21 são apresentadas as doze áreas identificadas a partir das palavras-chave escolhidas pelas/os autoras/es dos 399 textos publicados na ex æquo ao longo de duas décadas, divindindo-se a informação por quinquénios.

\section{Gráfico 20.}

Faces de Eva - Metodologias usadas, por quinquénio

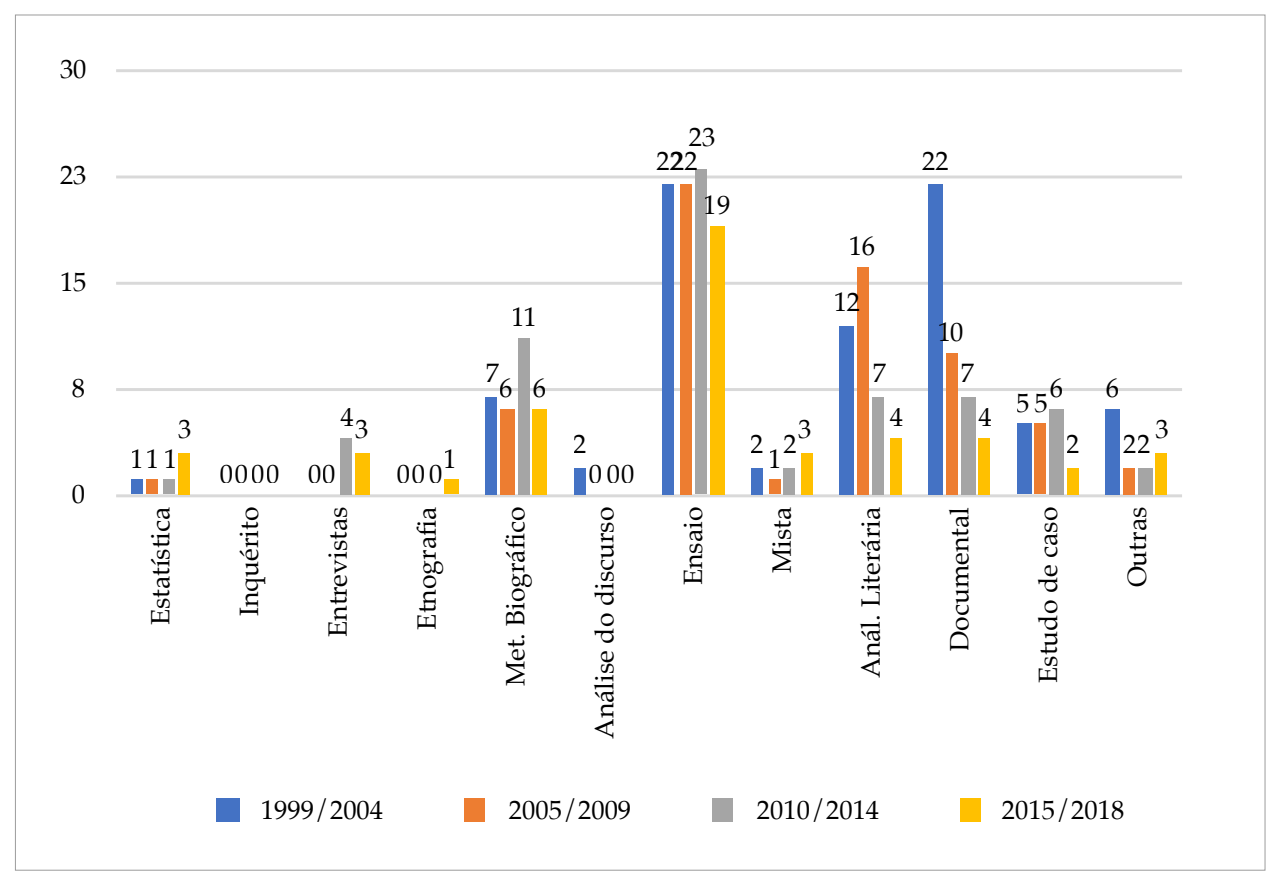

A diversidade de temáticas é assinalável e também aqui as categorias construídas e usadas para a análise da informação não se excluem mutuamente. A indispensável abordagem interseccional de algumas temáticas (ex: violências), a área de proveniência académica/institucional dos/as autores/as e ainda o período de publicação considerado são aspetos que, em nosso entender, não autorizam

A não inclusão da Faces de Eva nesta etapa do trabalho já foi justificada anteriormente, tendo-se devido sobretudo à não disponibilização em formato digital dos primeiros 31 números da revista e às alterações ao nível da formatação que foi sofrendo com os anos. 
uma leitura linear dos dados. É possível que a escolha das palavras-chave tenha sido influenciada por fatores ligados a tendências de mainstreaming em cada época, bem como pelo foco teórico-analítico a partir do qual os temas foram abordados. Também nos parece provável que a visibilidade de uns temas em relação a outros, em casa período considerado, não tenha sido independente das áreas científicas das pessoas que dirigiam as revistas, o que poderá ter-se refletido nas opções relativas à proposta de dossiês temáticos, às redes de cooperação científica que facilitaram certamente a preparação de submissões para publicação, entre outras potenciais questões que abordaremos em trabalhos posteriores decorrentes deste estudo bibliométrico.

\section{Gráfico 21.}

ex aequo - Áreas temáticas identificadas através dos resumos e palavras-chave, por quinquénio

30

23
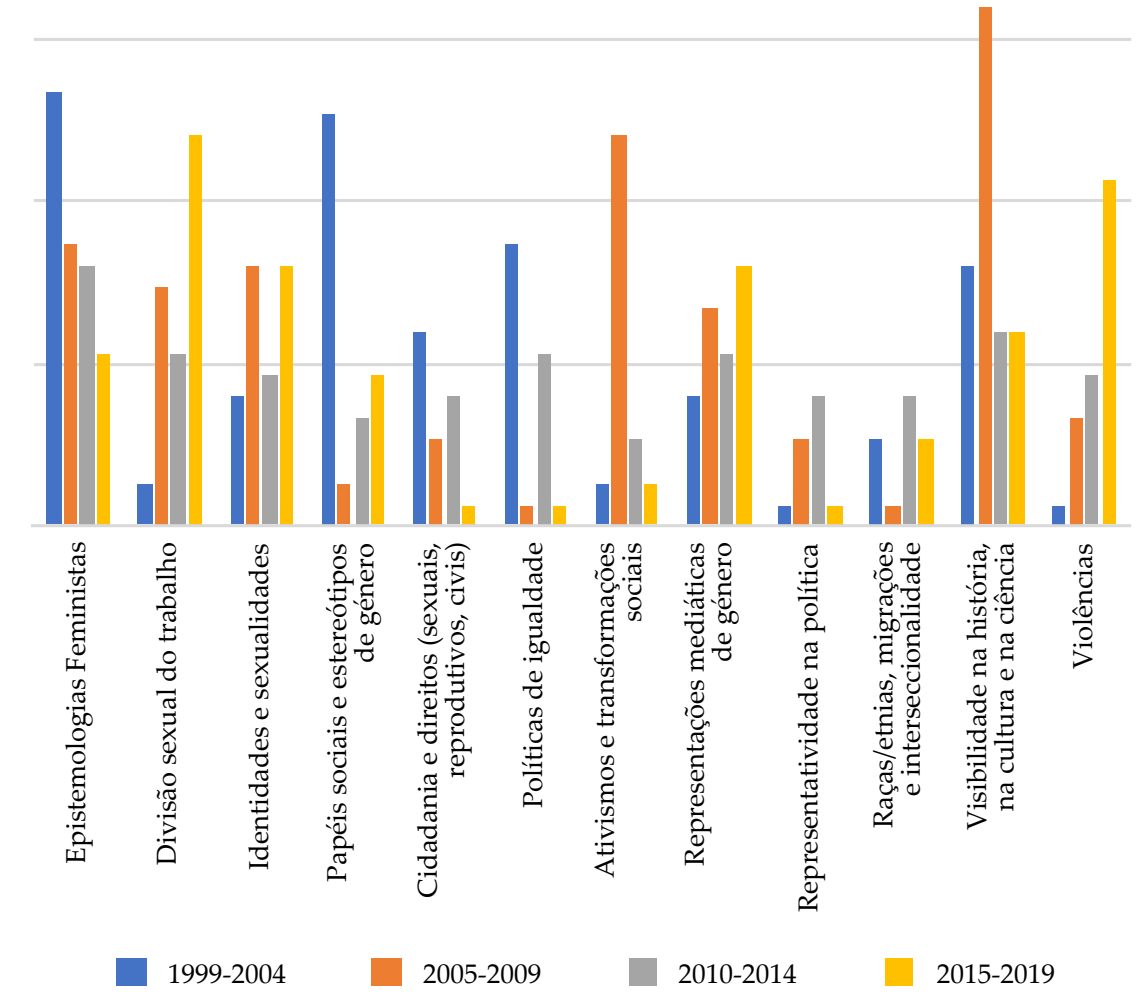


\section{Considerações finais}

O uso da bibliometria e da cientografia para avaliar o desempenho do trabalho científico e das publicações que o veiculam tem aumentado nas últimas décadas. A abordagem quantitativa tem sido objeto de várias críticas, como já foi sublinhado, considerando-se que ela não pode em caso algum substituir a arbitragem por pares. Privilegiando esta modalidade de avaliação, a arbitragem cega por pares, não quisemos deixar de fazer este exercício bibliométrico, como exercício complementar.

É importante enquadrar os dados apurados sobre as duas revistas no contexto dos EMGF, aos quais os estudos bibliométricos mais ou menos têm apontado as seguintes características: revistas com baixo factor de impacto que publicam artigos com poucas citações (Madison e Söderlund 2018, 1163). Seguimos, no entanto, aqui um importante princípio incluído no Leiden Manifesto (Hicks et al. April 2015) - não confundir o factor de impacto de uma revista com a sua qualidade científica. Enquanto noção multidimensional, a qualidade científica passa por critérios como a consistência, a originalidade e o valor social do conhecimento que produz, não podendo por isso ser captada por um único indicador quantitativo, ainda que composto.

O recurso a critérios cientométricos procura informar a tomada de decisão editorial para melhorar a qualidade das revistas, e respetiva promoção e internacionalização, a fim de reforçar o seu posicionamento no panorama editoral e no sistema científico dos EMGF. Neste caso, sendo esta a primeira publicação de outras que se seguirão, procurou-se sobretudo identificar as linhas mais marcantes no desenvolvimento desta área de estudos em Portugal e os caminhos que as suas duas únicas revistas que procuram afirmar-se neste campo têm percorrido.

\section{Agradecimentos}

Estudo financiado pela Comissão para a Cidadania e Igualdade de Género, através da sua medida de Apoio do Estado às ONGM, ao abrigo do Decreto-lei n. ${ }^{\circ}$ 246/98, de 11 de Agosto, alterado pela Lei n. ${ }^{o}$ 37/99, de 29 de Maio.

\section{Referências bibliográficas}

Giovanni Abramo, Ciriaco Andrea D’Angelo, and Alessandro Caprasecca. 2009. «Gender differences in research productivity: A bibliometric analysis of the Italian academic system». Scientometrics, 79(3), 517-539.

Abranches, Graça. 2009. Guia para uma linguagem promotora da igualdade entre mulheres e homens na administração pública. Lisboa: Comissão para a Cidadania e a Igualdade de Género.

Aksnes, Dag W., Liv Langfeldt, e Paul Wouters. 2019. «Citations, Citation Indicators, and Research Quality: An Overview of Basic Concepts and Theories». SAGE Open, 1-17. 
Amâncio, Lígia, e João Manuel de Oliveira. 2014. «Ambivalências e desenvolvimentos dos estudos de género em Portugal». Faces de Eva 32, 23-42.

Barroso, Margarida, Magda Nico, e Elisabete Rodrigues. 2009. «O lugar do género, dos homens e das mulheres na sociologia portuguesa: uma análise a partir da Associação Portuguesa de Sociologia e seus congressos». CIES e-Working Papers 64.

Bergano, Sofia, e Cristina C. Vieira. 2020. Do pessoal ao político: as metodologias de investigação qualitativa como aliadas da ação. ex æquo 41, 15-25. DOI: https:/ / doi.org / 10.22 355/ exaequo.2020.41.01

Borrego, Ángel, Maite Barrios, Anna Villarroya, and Candela Ollé. 2009. «Scientific output and impact of postdoctoral scientists: A gender perspective». Scientometrics, 83(1), 83-101.

Brilhante, Aline Veras Morais, Gracyelle Alves Remigio Moreira, Luiza Jane Eyre de Souza Vieira, and Maria Fontenelle Catribe. 2016. «A bibliometric study on gender violence». Saúde e Sociedade, 25(3), 703-715.

Conselho da Europa. 1990. Recomendação n. ${ }^{\circ}$ R (90) 4 do Comité de Ministros aos Estados-membros sobre a eliminação do sexismo na linguagem, adoptada pelo Comité de Ministros a 21 de fevereiro de 1990.

Conselho da Europa. 2007. Recomendação Rec (2007) 17 do Comité de Ministros aos Estados-Membros sobre Normas e Mecanismos para a Igualdade de Género, adotada pelo Comité de Ministros a 21 de novembro de 2007.

Cronin, Blaise. 1984. The citation process. The role and significance of citations in scientific communication. London: Taylor Graham.

Cronin, Blaise, Anna Martinson, and Elisabeth Davenport. 1997. «Women's studies: Bibliometric and content analysis of the formative years». Journal of Documentation, 53(2), 123-138.

Dehdarirad, Tahereh, Anna Villarroya, and Maite Barrios. 2015. «Research on women in science and higher education: A bibliometric analysis». Scientometrics, 103(3), 795-812.

Feldman, Zeena, and Marisol Sandoval. 2018. «Metric Power and the Academic Self: Neoliberalism, Knowledge and Resistance in the British University». tripleC 16(1): 214-233.

Ferreira, Virgínia. 2001. «Estudos sobre as Mulheres: A construção de um novo campo científico», ex æquo 5, 9-25.

Henriksen, Dorte. 2016. «The rise in co-authorship in the social sciences (1980-2013)». Scientometrics, 107(2), 455-476.

Hicks, Diane, Paul Wouters, Ludo Waltman, Sarah de Rijcke, and Ismael Rafols. April 2015. «The Leiden Manifesto for research metrics». Nature Vol 520, 429-431.

Hoppen, Natascha Helena Franz, and Samile Andréa de Souza Vanz. 2020. «What are gender studies: characterization of scientific output self-named gender studies in a multidisciplinary and international database». Encontros Bibli: revista eletrônica de biblioteconomia e ciência da informação 25, 01-30. DOI: https: / / doi.org/10.5007/1518-2924.2020. e71677

Joaquim, Teresa. 2004. «ex-æquo: Contributo Decisivo para um Campo de Estudos em Portugal». Estudos Feministas 12(N.E.) 264, 88-93.

Lykke, Nina. 2018. «Can't bibliometric analysts do better? How quality assessment without field expertise does not work». Scientometrics 117: 655-666. https:/ / doi.org/10.1007/ s11192-018-2872-x(

Madison, Guy, \& Therese Söderlund. 2018. «Comparisons of content and scientific quality indicators across peer-reviewed journal articles with more or less gender perspective: gender studies can do better». Scientometrics 115,1161-1183. 
McDermott, Patrice. 1994. Politics and scholarship: feminist academic journals and the production of knowledge. Urbana: University of Illinois Press.

Nunes de Almeida, Ana. 1986. «As mulheres e as ciências sociais - os sujeitos e os objetos de investigação«. Análise Social XXII (94), 979-985.

Pereira, Maria do Mar. 2012. «'Feminist theory is proper knowledge, but...': The status of feminist scholarship in the academy». Feminist Theory 13, 283-303.

Pesole, Betta. 2012. «The Feminist 'Successor Science Project' as a Transnational Epistemological Community», e-cadernos CES 18. Disponível em: http:/ / journals.openedition. org/ eces/1509. DOI: https: / / doi.org/10.4000/ eces.1509

Pinto, Teresa. 2009. «ex æquo - 10 anos em revista». ex æquo 19, 63-68.

Reason, Peter. 1994. «Participation in the Evolution of Consciousness.» In Participation in Human Inquiry, editado por Peter Reason, 16-29. London, Sage Publications.

Santos, Raimundo Nonato Macedo dos, e Nair Yumiko Kobashi. 2009. «Bibliometria, Cientometria, Infometria: Conceitos e Aplicações. Tendências da Pesquisa Brasileira em Ciência da Informação». Pesquisa Brasileira em Ciência da Informação e Biblioteconomia 2(1), 155-172.

Söderlund, Therese, \& Guy Madison. 2015. «Characteristics of gender studies publications: A bibliometric analysis based on a Swedish population database». Scientometrics, 105(3), 1347-1387.

Smith, Dorothy. 1987. Women's Perspective as a Radical Critique of Sociology. In Feminism and Social Theory, editado por S. Harding. Milton Keynes: Open University Press, 84-96.

Tsay, Ming-yueh, \& Chia-ning Li. 2017. «Bibliometric analysis of the journal literature on women's studies». Scientometrics, 113(2), 705-734.

Vieira, Ana Sara, Ana Júlia Coelho, Ana Sofia Miquelino, e Pedro Calado. 2016. «Faces de Eva - Um análise bibliométrica». Faces de Eva 36, 34-60.

Vieira, Cristina Maria. 1999. «A Credibilidade da investigação Científica de Natureza Qualitativa: questões relativas à Fidelidade e Validade». Revista Portuguesa de Pedagogia XXXIII(2), 89-101.

Yun, Bitnari; June Young Lee, and Sejung Ahn. 2020. «The Intellectual Structure of Women's Studies: A Bibliometric Study of its Research Topics and Influential Publications». Asian Women, 36(2), 1-23. 


\section{Anexo}

\section{Indicadores bibliométricos}

1) Número da revista ex æquo

2) Ano

3) Título do artigo

4) Nome de $1^{\circ}$ autor/a

5) Sexo da/o 1. ${ }^{\text {ao }}$ autor/a: Fem $=1$; Masc $=2$

6) Nome de 2. ${ }^{\circ}$ autor/a

7) Nome de $3 .^{\circ}$ autor/a

8) Nome de $4 .{ }^{\circ}$ autor/a

9) Nome de 5. ${ }^{\circ}$ autor/a

10) Autoria (de 0 a n)

11) Número de pessoas coautoras do sexo feminino (de 0 a n)

12) Número de pessoas coautoras do sexo masculino (de 0 a n)

13) Língua do artigo (Português $=1$; Inglês $=2$; Espanhol $=3$; Francês $=4$ )

14) País da instituição de filiação da/o $1 .^{\circ}$ autor/a

15) País da instituição de filiação da/o $2{ }^{\circ}$ autor/a

16) Instituição de filiação de $1 .^{\circ}$ autor/a (Universidade $=1$; Instituição pública $=2$; Outra $=3$ )

17) Instituição especializada em Género: $\operatorname{Sim}=1 ;$ Não $=2$.

18) Área disciplinar de 1 . $^{\circ}$ autor/a - Estudos Literários/Linguísticos $=1$; História $=2$; Sociologia $=3$; Psicologia $=4 ;$ Estudos Culturais e da Comunicação $=5$; Antropologia $=6 ;$ C. da Educação $=7 ;$ Direito $=8 ;$ Outras $=9 ;$ Filosofia $=10$

19) Tópico central do artigo

20) e-mail de todos/as os/as autores/as

21) Palavras-chave em Português 1

22) Palavras-chave em Português 2

23) Palavras-chave em Português 3

24) Palavras-chave em Português 4

25) Palavras-chave em Português 5

26) Palavras-chave em inglês 1

27) Palavras-chave em inglês 2

28) Palavras-chave em inglês 3

29) Palavras-chave em inglês 4 
30) Palavras-chave em inglês 5

31) Texto original $(=1)$ ou traduzido $(=2)$

32) País sobre o qual incide o estudo

33) Metodologia Quantitativa (estatísticas =1; inquérito = 2); Qualitativa (entrevistas = 3; etnografia $=4$; mét biográfico $=5$; análise do discurso $=6$ ); Ensaio $=7$; Entrevista a Mulheres importantes (caso das Faces de Eva) = 8; Análise de redes $=9$; Mista $=10$, Análise Literária $=11$; Documental $=12$; Estudo de caso $=13 ;$ Outras $=14$.

34) Usa palavra feminista/s (ou feminismo/s) de 0 a $n$ vezes

35) Usa a palavra género (ou derivadas) de $0 \mathrm{n}$ vezes

36) Usa linguagem inclusiva $=1$; masculino genérico $=2$

37) Número de obras citadas no total

38) Número de livros citados no artigo (de 0 a n)

39) Número de artigos em revistas citados no artigo (de 0 a n)

40) Número de outro tipo de publicações citados no artigo (relatórios; blogs; working papers) (de 0 a $n$ )

41) País mais frequente nas referências bibliográficas incluídas no artigo. 
Virgínia Ferreira. Professora Associada da Faculdade de Economia da Universidade de Coimbra (FEUC); Investigadora do Centro de Estudos Sociais (CES). Socióloga, com interesses de pesquisa sobre as desigualdades no mercado de trabalho, exclusão social, equilíbrio trabalho/vida familiar e políticas de igualdade sexual. Membro fundador da Associação Portuguesa de Estudos sobre as Mulheres. Tem publicado em revistas e coletâneas nacionais e internacionais.

Endereço eletrónico: virginia@fe.uc.pt

Cristina C. Vieira. Professora Associada da Faculdade de Psicologia e de Ciências da Educação da Universidade de Coimbra. Membro integrado do Centro de Investigação em Educação de Adultos e Intervenção Comunitária (CEAD) da Universidade do Algarve CEAD - apoiado por Fundos Nacionais através da FCT, no âmbito do Projeto UIDB/05739/2020. Ampla experiência de docência universitária na área das metodologias quantitativas e qualitativas de investigação em ciências sociais e humanas. Coautora dos cinco Guiões de Educação Género e Cidadania publicados pela CIG.

Endereço eletrónico: vieira@fpce.uc.pt

Maria João Silveirinha. Professora Associada da Faculdade da Universidade de Coimbra. Membro integrado do Centro de Investigação ICNova - Instituto da Comunicação da Nova. Docência universitária e investigação na área das Ciências da Comunicação, com particular interesse no cruzamento destas com as questões de género na comunicação e nos media.

Endereço eletrónico: mjsilveirinha@gmail.com

Elizângela Carvalho. Estudante de Doutoramento em Ciências da Comunicação na Universidade de Coimbra, bolseira FCT e associada ao Centro de Investigação ICNova. Na sua investigação doutoral, procura investigar o espaço destinado às mulheres no/a partir do jornalismo.

Endereço eletrónico: elizc.noronha@gmail.com

Priscila Freire. Estudante de Doutoramento em Sociologia na Universidade de Coimbra. Docente da Escola Superior Normal da Universidade do Estado do Amazonas (UEA), Manaus, Brasil. A sua tese de doutoramento incide sobre «Educação sensível ao gênero? Uma análise pós-estruturalista da política de educação do Brasil».

Endereço eletrónico: priscillafreyre@hotmail.com 


\title{
DREAMING THE WELFARE-STATE: INDIAN WOMEN-STUDIES- MOVEMENT, NEOLIBERALISM AND FEMINIST FUTURE
}

\author{
Cheshta Arora:
}

(D) https: / / orcid.org / 0000-0003-2470-7783

\begin{abstract}
Through an account of the history of women-studies-movements in India, the paper aims to interrogate the 'temporality' of feminist response to the neoliberal reality. By juxtaposing two dominant narratives situated differently, the paper appeals for a reevaluation of contemporary feminist knowledges that bemoan the loss of 'welfare state' and collective political struggles. Through a critical account of women-studies-movements in India, and the inability of their dominant stories to respond to the current conundrums of responding to the 'neoliberal' subject, the paper argues that it is not just the neoliberal reality which is hegemonic and all too powerful, but also the feminist stories that constitute it.
\end{abstract}

Keywords: Neoliberalism, feminist movement, sexual difference, welfare state.

\section{Resumo}

Neste artigo, através de uma descrição da história dos estudos e movimentos das mulheres na Índia, pretende-se interrogar a «temporalidade» da resposta feminista à realidade neoliberal. Ao justapor duas narrativas dominantes situadas de forma diferente, apela-se a uma reavaliação dos conhecimentos feministas contemporâneos que lamentam a perda do «Estado-providência» e das lutas políticas coletivas. Através de uma descrição crítica dos estudos e movimentos das mulheres na Índia, e da incapacidade das suas histórias dominantes em responder aos atuais dilemas de dar resposta ao tema «neoliberal», argumenta-se que não é apenas a realidade neoliberal que é hegemónica e demasiado poderosa, mas também as histórias feministas que a constituem.

Palavras-chave: Neoliberalismo, movimento feminista, diferença sexual, Estado-providência.

\section{Resumen}

En este artigo, a través de un relato de la historia de los estudios y movimientos de mujeres en la India, se busca interrogar la «temporalidad» de la respuesta feminista a la realidad neoliberal. Al yuxtaponer dos narrativas dominantes situadas de manera diferente, se apela a la reevaluación de los conocimientos feministas contemporáneos que lamentan la pérdida del «Estado de bienestar» y las luchas políticas colectivas. A través de un relato crítico de los estudios y movimientos de mujeres en la India, y de la incapacidad de

Manipal Academy of Higher Education (MAHE), Manipal, Karnataka 576104, India; School of Social Sciences, National Institute of Advanced Studies (NIAS), Bengaluru, Karnataka 560012, India.

Postal address: Room No.9, National Institute of Advanced Studies, IISc Campus, Bengaluru, India -560012 .

Electronic address: cheshta@nias.res.in 
sus historias dominantes en responder a las incógnitas actuales de dar respuesta a la cuestión «neoliberal», se sostiene que no sólo la realidad neoliberal es hegemónica y demasiado poderosa, sino también las historias feministas que la constituyen.

Palabras-clave: Neoliberalismo, movimiento feminista, diferencia sexual, Estado de bienestar.

\section{Introduction}

We do not also seem to be overly vexed about the coordinates of our knowledge-making enterprises... Have we built knowledge adequate for contemporary and future feminisms?

(Sreekumar 2017, 63)

Sreekumar posed the above question to the women-studies-movement in India arguing that our dominant story-telling obliges «our knowledge projects to attach themselves to current temporalities and politics...on the here and now ${ }^{1} »$ where «women studies is inclined to conceive the 'political' in crucially delimited ways - as covering the ground of (i) reform, (ii) citizenship and (iii) development» (ibid.). The term 'women studies movements' is used in the existing literature (Jain 1999; Pappu 2002) to refer to the mobilization for introducing women studies as a discipline in higher education in the 1970s in India. Sreekumar uses it with hyphenation, as 'women-studies-movement' (henceforth, WSM) to refer to the conjoint formation of women studies and women's movement in India post-1970s and locates certain tendencies within the WSM's narrative of itself. Her focus is on two stories that are always invoked to mark the beginning of women's studies in India ${ }^{2}$. She describes the first story as «the long fertile $19^{\text {th }}$ century with its clamour over the 'women's question'»3 (47), and the second as the «tumultuous decade of

See Das (2012) for a more extensive critique of politics caught in the here and now.

While a focus on tendencies always comes at a cost of generalization, it also allows us to think about the current predicaments and possibilities. Thus, a certain account of India's WSM is offered here at the cost of generalization but with footnotes wherever necessary to guide the interested readers.

3 This period overlaps with the period of Social Reform Movement in India that spanned from 1850s to 1940s; it focused on 'uplifting' women to eradicate social issues such as widow immolation, child marriage and struggled under that shadow of colonialism (Gandhi and Shah 1992; Khullar 2005). This period is well researched by feminist historians in India interrogating the ways in which the woman's question was tied to complex play of modernity and tradition and how Indian women's emancipation became synonymous to the reformation of the 'social' for the new breed of 'educated natives'; and the complex agency of the Indian women during this period - see Chatterjee (1987), Mani (1989), Sangari and Vaid (1989), Tharu and Lalita (1991), Chakravarti (2013). This literature, however, is contested by scholars who mark out other voices and movements during this period that weaved starkly different relationships between «the 
the 1970s» ${ }^{4}$ (ibid.) which witnessed the publication of the Towards Equality report $(1975)^{5}$, the emergence of autonomous women's movements in India and the establishment of women-studies centres in universities and the institutes of higher education.

By mapping the granularities of feminist/women's movement in India post1970s and its entanglements with the mood, economy and politics of neoliberalism, the first part of this paper argues that WSM did not just respond to the structural crises that erupted during the 1970s (Calman 1989), but was structured by this crises, as is reflected in its self-narrative post-1990s; also, that it is its own particular affective story-telling which contributes to a production of 'neoliberalism' as an all-encompassing hegemonic phenomenon. Consequently, its despair and hopelessness in the face of neoliberalism should be seen in light of this perceived moment of origin. The second section engages with the debate between Fraser and Butler vis-à-vis recognition and redistribution and the notion of 'threatening feminism' that Rottenberg weaves as a counter to neoliberal reality to argue that the figure of a welfare state prefigures and haunts all these texts as a certain future to fight for despite its failures everywhere.

By locating a certain tendency in the self-narrative of WSM, the text distinguishes «between a hope that does not yet have an end in view... and a hope that is (as hook suggests) so oriented to a specified future that no genuine rupture with the present would occur» (Colebrook 2010, 323-324). A self-narrative of hope or loss oriented towards a specified future promised by the welfare state cannot face the challenge of neoliberalism. Dream of a welfare state continues a hope in a certain idea of 'development' in which the place of woman (as educated, empowered, and equally distributed along the status quo), of politics (negotiation, advocacy between the civil society and the government), of a good life (of dignified

social, the political and the religious... gender is inextricably interwoven with caste, community and religion, ... chart[ing] very different modes for woman's emergence - both as a social and as an epistemic category» (Sreekumar 2017, 54). See also Rege (2013) and Sreemukar (2017) for detailed references to mark these diverse voices.

This period is identified as the 'third' phase of women's movement in India that began post1970s. Calman (1960) identifies two tendencies within the contemporary women's movement in India: First, «the rights wing», which focusses on issues of rights and equality and is largely urban-based. It engages with the government to pass and administer laws related to family matters, education, employment, health and violence against women. The other wing of the movement, the «empowerment» wing, with both urban and rural components and financial help from national and international funders, focusses on issues such as livelihoods, literacy, alcoholism, environment, reservation for women in local governments. The diverse groups working within the «rights» wing of the movement are either affiliated to political parties, independent social service agents, or autonomous organizations. Urban, middle-class and educated women play a crucial role in both the wings, which makes the two complementary to each other. This report was commissioned by the Government of India (GOI) in 1974. Its exact implications on the WSM are discussed later in the text. 
work and consumption) is always already given and is also reiterated in the vision that 'neoliberalism' sells. Thus, a certain hope oriented towards a specified future in welfare state will always give way to a certain despair vis-à-vis neoliberalism. Instead, the text pushes the reader towards a certain hopelessness «directed towards the present» (yet nurturing a certain hope that doesn't yet have an end) in order to «map out some future that is at once other than the present and yet referenced to an unfulfilled actuality of the present» (Colebrook 2010, 332). Finally, a move towards sexual difference as 'pure difference' that can open up the ground work to reimagine feminist relationship with time, space, and scale is hinted at in the end.

\section{Two crises}

\section{0-1990}

Post-1990s, the network of women studies scholars showed an active interest in documenting WSM in India ${ }^{6}$ as it realized that liberalization had changed the «terms of political discourse» (Agnihotri and Mazumdar 1995). Two challenges were identified for the future of WSM in India: (i) rise of the Hindu right-wing in national electoral politics (ii) rise of the middle-class and the consequent hypervisiblization of middle-class women post-1990s (Tharu and Niranjana 1994; John 1998). Similar to the lament that appeared in the Anglo-centric feminist scholarship on neoliberalism (Hemmings 2005; Roy 2009), members of the WSM mourned the loss/death of autonomous women's movements in India that flourished in the 1970s and 1980s.

The loss was expressed through the following three fears - (i) institutionalization, professionalization and NGOisation (Roy 2011) of the women's movement (ii) hyper-visiblization of middle-class, upper caste women and their claim to feminist politics (iii) the growing rift between women studies and women's movement marking the influx of postmodern/poststructuralist theories. Three kinds of responses emerged from these fears. First, a generational response took stock of the history of women's movement in post-independence India, its thrust areas, and proposed strategies for the future where the legacies of 1970s and 1980s were to be remembered and taken forward. Second response, accepting defeat, bemoaned the loss of women's movement, and the third response took the form of self-blame (Roy 2015). The 'future' of feminist praxisin all three responses appeared

See Kumar (1989; 1993), Gandhi and Shah (1992), Mazumdar (1994; 2007), Agnihotri and Mazumdar (1995), John (1996; 2008; 2014a), Patel (1998), Jain (1999), Ray (1999), Bhagwat and Rege (2002), Sharma, Kasturi, and Sarkar (2002), Pappu (2002), Khullar (2003), Roy (2009; 2011; 2015), Sharma (2017). 
either circular, i.e., as that which that will recover or repeat the glories of the past, or bleak, i.e., imagination of which has been collectively stifled, muted or subdued by the crises.

The seeds of this predicament, however, can be traced back to that moment in the narrative when the events of the 1970s are perceived as originary of WSM in India. In 1975, the then Prime Minister Indira Gandhi ${ }^{7}$ declared a 21-month long emergency from 1975-1977, which led to a suspension of elections and all civil liberties in India. It also-saw the emergence of various social movements, including women's movement and the publication of the Towards Equality (1974) report which highlighted the failures of the postcolonial state and its promises but, simultaneously, introduced various policy measures, sustaining hope in the temporal promise of postcoloniality. The report, thus, ruptured as well as consolidated the contract of the postcolonial state with its citizenry.

Multiple aspects of the report need to be considered to understand its significance, to understand how it became 'constitutive' of the narrative of 'loss' in the 1990s. First, it highlighted the failures of the Indian state, its «systemic discrimination and structural constrains for women in the development process» (Sharma 2017, 80-81), and caused a "crisis of conscience» among the authors of the report who considered themselves to be «the first generation beneficiaries of the equality clauses of the Constitution» (Mazumdar 2007, 106). Second, the report, regarded as a point of origin of WSM in India (Sharma 2017), became a site to (re) perform the nationalist fervour and (re)inscribe the faith in the promises of the postcolonial state. It is rife with references to the Constitution and its guarantees with an emphasis on the role of women in 'nation-building' giving new lease to the Nehruvian state and its imagined economy of socialist development, with (poor) working women at the center of it (John 1996).

Thus, for WSM, the report became a site of both critique and participation in the working of the state, a double-edged sword, surprisingly untainted by the repressive arm of the state that sanctioned it for the UN's first world conference on women in Mexico (John 2014b). The crises of the legitimacy of the postcolonial state, and the 'crises of conscience' for the members of WSM affected by the findings of the report inspired the movement and its (middle-class) actors to participate and make concrete the 'dream' of the postcolonial nation to provide for its citizens and become the primary organ of governance. It allowed them to partake and struggle anew for the postcolonial state which was promised but never delivered. Contrary to the Anglo-centric accounts that bemoan the loss/failure of an already existing albeit failing 'welfare state' (Eisenstein 2017), the 'loss' in the narrative of Indian WSM is a loss of a 'dream' of a welfare state that never really

Indira Gandhi, the first and only female Indian Prime Minister, was in office from 24 January 1966 to 24 March 1977, and from 14 March 1980 until her assassination in 31 October 1984. She was the daughter of Jawaharlal Nehru, the first Prime Minister of independent India. 
materialized but was promised by the postcolonial condition. Vibrant with a hope in the temporal promise of postcoloniality, WSM took it upon itself to realize the promise that was already faltering by the 1970s. It is the shock of structural adjustments during the 1990s that jolted the WSM in India, dreaming the dreams of the postcolonial 'welfare' state into a neoliberal 'reality'.

\section{0s-present}

The scholarship in the last twenty decades that began with the narratives of loss (of a dream) is followed by sporadic responses to this loss that further entrenched the 'neoliberal reality'. Thus, against the despair of the members of women-studies-movement, Roy (2011) argues for a paradigm which understands NGOs outside of the binary logic that produces them either as «do-gooders» or «sell-outs» and situates NGOs in the context of their ambivalent origins, heterogeneous and hybrid ways of functioning. Drawing from an earlier critique of 'loss', 'despair', and 'anxiety' in women's movement, Roy (2009; 2012; 2015) argues that hyper-visiblization can also suggest that feminism in India was not just alive and well but had achieved a commonsensical status.

While Roy's (2015) response to the crises is to introduce NGO's as necessary research objects and political actors in the contemporary social movement that had privileged 'autonomous collectives' to be the norms of feminist movements, John (1998) offered a conceptual and methodological alternative to re-evaluate the contours of postcolonial feminist knowledges in the given crises. According to John (1998), the fundamental concept that needs re-evaluation to mitigate the crises is 'gender', where she argues that unlike in the 'west', the problem of gender in India is less about the binary logic of sex/gender which has been a concern for multiple authors in the west. In contrast, another pair is proposed - culture \& politics - and history as a point of departure. Finally, drawing from this reconceptualization, two kinds of inquiries are theorized to be adequate for women studies scholarship in India: 1) providing better picture of 'meanings' and 'social locations' and 2) by conducting a genealogical exercise of our conceptual resources, understanding how social, political cultural, historical sedimentations change the meaning of some concepts in different settings.

These two responses have come to dominate the women studies scholarship in India on entanglements of women, gender and liberalization and the rise of the figure of the 'new women' and its tryst with modernity, liberalization and globalization ${ }^{8}$. An instance of this can be gauged through the literature that studies

To make this argument I focus on recent literature that offers ethnographies of women situated at the center or at the margins of the new economy through the lens of available subjectivities and modes of resistance. There are other works that focus on the processes of neoliberalism and 
the entry of middle-class women in new service industries that have come to thrive on the Indian economic and cultural landscape post-1990s. Over the past two decades the subjectivities of these 'new (middle-class) women' have been defined as 'appropriate', 'respectable' (Radhakrishnan 2009), and 'balanced' (Gilbertson 2014). Post-2010, such theorizations trickle down to other groups, documenting the flexible strategies of women marked by their caste and class locations (Vijayakumar 2013; Twamley and Siddharth 2019) but still aspiring to be 'appropriate' and 'respectable'.

These works either implicitly repeat the feminist narrative of 'loss' since this new globalized middle-class (women) of the 1990s don't experience the 'crises of conscience' that was available to the middle-class (women) of the 1970s (Deshpande 1998). Or a second response, in its attempt to find a way out of the impasse mentioned above, rests on the binary of west/east wherein it argues that 'resistance' is to be understood differently from the western standards where Indian women become 'entrepreneurial activists' (Gupta 2016) indulge in 'patriarchal bargains' (Twamley and Siddharth 2019) or 'relational reflexivity' as opposed to 'reflexive modernity' (Belliappa 2013). The scholarship, implicitly, comes to follow the mandate laid out by John (1998), (i) they offer rich descriptions of 'meanings' and 'social locations' that women come to occupy and (ii) how these locations, their social and cultural histories allow different modes of resistance, and of Roy (2015), where new arrangements are not to be seen in terms of a 'lack' when compared to the past arrangements but are simply situated in the logic of the present.

The political and scholarly responses to the contemporary feminist impasses mapped above limit the scalar, spatial and temporal reaches of feministengagement. Temporally, they offer either a glorious past, or an ambivalent, hybrid present as only two points of references for feminist engagement/theorizations. Spatially, they legitimize their scholarly accounts of resistance and politics by reiterating power difference between west and east. And in terms of scale, they offer a choice between either the benevolent nation-state vs. the adventurous free-market. WSM in India, albeit critical of these processes, is divided along these lines. The scholarship, which takes 'women' as its research object performs a politics of difference, of postcoloniality, which consequently tends to celebrate different modes of resistance and positionalities. This scholarship concerns itself with producing the feminist knowledge of the postcolonial marginal and takes its visiblization as a political task. The second scholarship takes the contours of 'women's movement' as its research object whereby a concrete and coherent movement is first identified and

their relation to intensified violence against women (Bannerji 2016), consumerism and nationalism (Chaudhary 2017) and financial services (Kabeer 2005).

«Patriarchal bargains» was first theorized by Kandiyoti (1988) to theorize different forms of patriarchy, used by Twamley and Siddharth (2019) to make sense of bargaining subjectivities in the neoliberal context. 
fixed in some near past, and its 'loss' in the present is bemoaned or a plea is made to adjust to the ambivalent, hybrid present. These available spatial, scalar, and temporal choices as the only choices available, however, are never contested. The WSM in India refuses to be multi-sited (Sreekumar 2017).

\section{Master narratives and their critiques}

What would it mean for WSM to become multi-sited? A plea for contextspecific feminist articulations was made in the 1980s when faced with a postmodern reality, third-world feminist articulations and the death of a subject. Both 'neoliberalism' and 'postmodernism', overlapping on historical time, drew charges of de-politicization, paralysis, and end of collective social movements (Butler 1992; Zalewski 2004). To make sense of these responses, the defenders of postmodernism offered two responses: 1) an explicit theoretical/political program for 'postmodern feminism' taking into account the new complexities of neoliberalism and conscious of third-world, de-colonial realities, 2) A more radical 'mode of critique' that destabilizes all attempts at a coherent definition/mandates ensuing from the terrain of 'postmodern'. This response aggressively defended postmodern as a 'way of seeing', a mode of critique that begins with a premise of 'anti-foundationalism'.

Fraser and Nicholson's (1988) treatment of postmodern feminism best exemplifies the first response. To the challenge of postmodernism which leads to an interrogation of 'woman' as an empirically given subject of feminism, and 'patriarchy' as a holistic system, they offered a six-point theoretical programme for postmodern feminism. On the other hand, avoiding any direct definition/mandate of 'postmodern feminism', Butler (1992) begins with a more fundamental question, «what is postmodernism?» and excavates layer by layer how something becomes a term, capable of producing effects of loss, nihilism and impending doom.

The crisis of 'postmodernism' becomes a fertile ground for enunciation of two kinds of registers for feminist politics. While Fraser's reformulation is hinged on democracy and inclusion within political economy as a site of feminist struggle and intervention as she makes a demand for 'redistribution' in addition to recognition, postmodernism's challenge to the subject of feminism allows Butler to reformulate and introduce 'culture' as a site of legitimate subversion of the political economy as well as the 'states' of being (Butler and Spivak 2007).

However, the old dichotomy of 'materialism/culture' as base/superstructure comes to haunt these two formulations and renders them irreconcilable. Moreover, the two formulations come to repeat the same political impasses within feminist theory and politics which are posed and constituted by the neoliberal crises as is apparent in the continued debate between Fraser (Fraser 1997; Fraser and Honneth 2003) and Butler (1998; Butler and Spivak 2007). It appears that it was 'relatively' 
easier for feminist scholars to accept the 'death of a subject' than the 'death of a (promise of a) welfare-state ${ }^{\prime 10}$.

There is no real consensus among scholars on the relationship between neoliberalism and postmodernism. In some narratives, neoliberalism is seen as a 'new master narrative' (Braidotti 2005) succeeding the end of postmodernism, while for others 'postmodern theory' is a handmaiden of neoliberal market economy (Mohanty 2013) legitimizing individual desires, less confrontational policy of gender mainstreaming over collective, feminist action (Baden and Goetz 1997; Bacchi and Eveline 2003; Fraser and Honneth 2003; McRobbie 2009; Kantola and Squires 2012; Wilson 2015; Eisenstein 2017; Newman 2017). Neoliberalism is marked by various characteristics but predominantly by certain historical amnesia, a forgetting, a regression, and lapses of memory, ignorance or a certain resurgence in popular media which comes with a neoliberal appropriation forsaking emancipatory goals of feminism (Rottenberg 2018). This appropriation is perceived as another ground (like postmodernism, previously) to introduce certain fissures in the feminist movement as it divides women into «aspirational and non-aspirational cohorts, with different roles and expectations for two groups» (Rottenberg 2018, X). Consequently 'neoliberalism' becomes a phenomenon against which a feminist theory has to strike back (Braidotti 2005), become «threatening... with 'precarity' as a unifying factor» (Rottenberg 2018, X) re-signifying neoliberal feminism into a more «vigorous and inclusive ideology» (ibid.)

Thus, a feminist response, attuned towards political economy, falls back to a certain belief in state institutions. For instance, after defining the necessity for a 'threatening feminism', the meaning of which is grounded in political movements such as Feminism for 99, Black Lives Matter, code pink, and the feminist anti-war movement, Rottenberg (2018) insists upon the necessity of institutions needed to complement the above cited political movements and thus, falls back to an already available, vertical, institutional imagination of a 'welfare state'. A political continuation between her call for a 'threatening feminism' and feminist investment in the institution of state is supported by a concluding rhetoric of 'capturing' state. Suddenly, an army of 'us' is formed, which is presumed to be a collective constituted independently of the discursive power of the state-market nexus and is capable of 'capturing' the institution of state. One finds a similar reaffirmation of 'welfare, Keynesian state' in Eisenstein's narrative of shift from 'hegemonic feminism' of (US) government to 'transnational business feminism'

10 Who sings the nation state, book developed out of a conversation between Butler and Spivak (2007), seeks to interrogate this entity called nation-states, and its constitutive 'states', such as nationalism, statelessness, sovereignty produced by it. In opposition, critical regionalism, global, and a notion of an 'abstract state' are hinted at. A certain notion of 'welfare state', as an abstract bureaucratic entity, cleansed of its nationalism, is merely imagined as an ally that brings their position closer to Fraser's defense of welfare state as necessary to demand redistribution. 
(2017). Her account stands on the presumed violence wrought on the 'third-world state' by the neoliberal adjustment programs that «coerced opening of national economies to an unlimited influx of foreign capital and manufacturing» (36). A certain victimization of 'third-world state institutions' then becomes necessary to illustrate the regression of the "progress of the $60 \mathrm{~s}$ and $70 \mathrm{~s}$ », to argue for a revitalization of a 'welfare state' everywhere tout court, obliterating the fact that a partial 'success', if at all, of these institutions is a historically specific reality mostly exclusive to 'developed' countries.

\section{Feminist futures}

Anglo-centric feminist responses to 'neoliberalism' are too caught up in the immediacy of social movements, politics and intervention which limit it to merely oscillate between recreating, rejuvenating the promise of the welfare state, autonomous feminist movements or accept the present of NGOs as ambiguous actors of the neoliberal market (Funk 2013; Roy 2015). What is needed to arrest this swing of the pendulum is a rearrangement, in our narratives, of the given order of space, scale and time by a different logic that presupposes equality rather than perceive it as an end to be achieved. Even though this order is disrupted regularly through different movements and everyday struggle, our narratives play an inconspicuous role in containing the disruption and the chaos of politics, and the eruption of political that occurs in these movements is sanitized by the narratives. Thus, in the narrative of WSM, a state-sponsored report becomes the 'watershed moment' (strengthening the vertical order - of state at the top, civil society [WSM as mediators] and the 'poor women' at the bottom); and, in Rottenberg's narrative, the diverse 'threatening feminism' is contained by a singular, temporal end of a strong welfare state to be captured by an army of us (even though after the capture the army of us will again be distributed along the vertical order of state, civil society and grassroots). Like feminist interventions to historiography where one studies the past against the grain, through the absence and silences that constitute it, the neoliberal moment offers us a chance to study our present narratives against the grain and the silences that constitute it.

This paper has been hinting at following three orientations vis-à-vis neoliberalism that have been available as critiques for past few decades but are reiterated here to usher in different feminist narratives and praxis. Hence, instead of bemoaning the loss of welfare state or launching feminist campaigns to lay claim to it, (i) the advent of neoliberalism makes visible the cracks in the very institution of 'welfare state' as an entity which by its very design is never sustainable for all, sustained and constituted as it is by certain states of violence, exclusion, statelessness, imperialism. Instead of accepting the market as the new reality (as inherent in Roy (2011) and other positions discussed previously), (ii) we should be 
interrogating the cracks in the previous feminist regime of representationism and an over-reliance on 'here and now', where a privileged few from the north, from the middle-class, from the west etc. take it upon themselves to represent and empower everyone else while continuing their faith (albeit critical) in narratives of progress, development and empowerment, every time giving new lease to the present order. Finally, (iii) it also makes visible the cracks in any reliance on development and progress (feminist or otherwise) which by its very design renders the vast majorities on the globe 'underdeveloped', doomed forever to play the game of catch-up, of empowerment.

It remains to be seen how/what kind of political, theoretical groundwork is needed to sustain such orientations as commonsensical part of our narratives. A move towards sexual difference as 'pure difference', as an infinitive 'to differ', and a certain hopelessness directed towards the present order, 'introducing another relation to time' (Colebrook 2004; 2010) allows the ground work necessary to rethink the coordinates for feminist movement - outside of already available (though contingent) scales such as local, state, nation, transnational. While 'sexual difference' requires work in terms of its convergence with race, class and other differences and the kind of questions that it dis/enables, 'sexual difference' as a concept has traversed multiple meanings, definitions and rhetoric. It began as a specific anatomical difference between already available, quantifiable men and women and developed to signify pure difference, as an ontological condition that suggests a necessity in life 'to differ' (Colebrook 2010). It is this ontological condition 'to differ' that at least allows us to pose the aforementioned questions vis-à-vis neoliberalism, gender and feminist politics, ushering a narrative outside of loss or acceptance, of the here and now, the universal and the particular.

\section{References}

Agnihotri, Indu, and Vina Mazumdar. 1995. «Changing Terms of Political Discourse: Women's Movement in India, 1970s-1990s». Economic and Political Weekly 30 (29): 1869-1878. JSTOR: https:/ / www.jstor.org/stable/ 4403023.

Bacchi, Carol, and Joan Eveline. 2003. «Mainstreaming and Neoliberalism: A Contested Relationship». Policy and Society 22 (2): 98-118. DOI: https:/doi.org/10.1016/S14494035(03)70021-6.

Baden, Sally, and Anne Marie Goetz. 1997. 'Who Needs [Sex] When You Can Have [Gender]?: Conflicting Discourses on Gender at Beijing'. Feminist Review 56 (1): 3-25. DOI: https:/ doi.org/10.1057 / fr.1997.13.

Bannerji, Himani. 2016. «Patriarchy in the Era of Neoliberalism: The Case of India». Social Scientist 44 (3/4): 3-27. JSTOR: https:/ / www.jstor.org/ stable/24890241.

Belliappa, J. 2013. Gender, Class and Reflexive Modernity in India. London: Palgrave Macmillan. DOI: https:/ / doi.org/10.1057/9781137319227.

Bhagwat, V., and Sharmila Rege. 2002. Our Story: Twenty Years of IAWS. Pune: Indian Association for Women's Studies. 
Braidotti, Rosi. 2005. «A Critical Cartography of Feminist Post-Postmodernism». Australian Feminist Studies 20 (47): 169-180. DOI: https: / doi.org/10.1080/ 08164640500090319.

Butler, Judith, and Gayatri Chakravorty Spivak. 2007. Who Sings the Nation-State? Language, Politics, Belonging. London: Seagull Books.

Butler, Judith. 1992. "Contingent Foundations: Feminism and the Question of 'Postmodernism'». In Feminists Theorize the Political, edited by Judith Butler and Joan W. Scott, 3-21. New York: Routledge.

Butler, Judith. 1998. «Judith Butler, Merely Cultural, NLR I/227, January-February 1998». New Left Review 1 (227). Available at https: / / newleftreview.org/ issues / I227 / articles / judith-butler-merely-cultural.

Calman, Leslie J. 1989. 'Women and Movement Politics in India'. Asian Survey 29 (10): 940-58. Doi: https: / / doi.org/10.2307/2644790.

Chakravarti, Uma. 2013. Rewriting History: The Life and Times of Pandita Ramabai. New Delhi: Zubaan.

Chatterjee, Partha. 1987. The Nationalist Resolution of the Women's Question. Calcutta: Centre for Studies in Social Sciences.

Colebrook, Claire. 2004. «Postmodernism Is a Humanism: Deleuze and Equivocity». Women: A Cultural Review 15 (3): 283-307. DOI: https:/ doi.org/10.1080/0957404042000291427.

Colebrook, Claire. 2010. «Toxic Feminism: Hope and Hopelessness after Feminism». Journal for Cultural Research 14 (4): 323-335. DOI: https: / doi.org/10.1080/14797581003765291.

Das, Anirban. 2012. Toward a Politics of the (Im)Possible: The Body in Third World Feminisms. Cambridge: Cambridge University Press. DOI: https: / doi.org/10.7135/UPO978184 3313427

Deshpande, Satish. 1998. «After Culture: Renewed Agendas for the Political Economy of India». Cultural Dynamics 10 (2): 147-169. DOI: https:/ doi.org/10.1177/092137409 801000205

Eisenstein, Hester. 2017. «Hegemonic Feminism, Neoliberalism and Womenomics: «empowerment» Instead of Liberation?» New Formations 91 (91): 35-49. DOI: https:/ doi.org/ 10.3898/NEWF:91.02.2017.

Fraser, Nancy, and Axel Honneth. 2003. Redistribution or Recognition? A Political-Philosophical Exchange. London: Verso.

Fraser, Nancy, and Linda Nicholson. 1988. «Social Criticism without Philosophy: An Encounter between Feminism and Postmodernism». Theory, Culture E Society 5 (2-3): 373-394. DOI: https: / doi.org/10.1177/0263276488005002009

Fraser, Nancy. 1997. 'Heterosexism, Misrecognition, and Capitalism: A Response to Judith Butler'. Social Text, no. 52/53: 279. Doi: https: / / doi.org/10.2307/ 466745.

Funk, Nanette. 2013. «Contra Fraser on Feminism and Neoliberalism». Hypatia 28 (1): 179-196. DOI: https:/ doi.org/10.1111/j.1527-2001.2011.01259.x.

Gandhi, Nandita, and Nandita Shah. 1992. The Issues at Stake: Theory and Practice in the Contemporary Women's Movement in India. New Delhi: Kali for Women.

Gilbertson, Amanda. 2014. «A Fine Balance: Negotiating Fashion and Respectable Femininity in Middle-Class Hyderabad, India». Modern Asian Studies 48 (1): 120-158. DOI: https: / doi.org/10.1017/S0026749X1300019X.

Gupta, Hemangini. 2016. 'Taking Action: The Desiring Subjects of Neoliberal Feminism in India' 17 (1): 18.

Hemmings, Clare. 2005. «Telling Feminist Stories». Feminist Theory 6 (2): 115-139. DOI: https: / doi.org/10.1177 / 1464700105053690 
Jain, Devaki. 1999. "Women's Studies: A Crucial Key to Feminist Purpose". Paper presented at the University Grants Commission and IAWS Workshop on Women's Studies, Chandigarh, 15-17 April.

John, Mary E. 1996. «Gender and Development in India, 1970s-1990s Some Reflections on the Constitutive Role of Contexts». Economic and Political Weekly 31 (47): 3071-3077. JSTOR: www.jstor.org/stable/4404800.

John, Mary E. 1998. 'Feminism in India and the West: Recasting a Relationship'. Cultural Dynamics 10 (2): 197-209. https: / / doi.org/10.1177/092137409801000207.

John, Mary E. 2014a. «Feminist Vocabularies in Time and Space». Economic and Political Weekly 49 (22): 7-8. JSTOR: https: / / www.jstor.org/ stable/24479646.

John, Mary E. 2014b. 'The Emergency in India: Some Reflections on the Legibility of the Political'. Inter-Asia Cultural Studies 15 (4): 625-637. DOI: https: / doi.org/10.1080 / 1464 9373.2014.980558.

John, Mary E. ed. 2008. Women's Studies in India: A Reader. New Delhi: Penguin Books.

Kabeer, Naila. 2005. «Is Microfinance a 'Magic Bullet' for Women's Empowerment? Analysis of Findings from South Asia». Economic and Political Weekly 40 (44/45): 4709-4718. JSTOR: https: / / www.jstor.org/stable/4417357.

Kandiyoti, Deniz. 1988. «Bargaining with Patriarchy». Gender \& Society 2 (3): 274-290. DOI: https:/ doi.org/10.1177/089124388002003004.

Kantola, Johanna, and Judith Squires. 2012. «From State Feminism to Market Feminism?» International Political Science Review 33 (4): 382-400. DOI: https:/doi.org/10.1177/01 92512111432513.

Khullar, Mala, ed. 2005. Writing the Women's Movement: A Reader. New Delhi: Zubaan.

Kumar, Radha. 1989. «Contemporary Indian Feminism». Feminist Review 33 (1): 20-29. DOI: https:/ doi.org/10.1057/ fr.1989.28.

Kumar, Radha. 1993. The History of Doing: An Illustrated Account of Movements for Women's Rights and Feminism in India, 1800-1990. New Delhi: Kali for Women.

Mani, Lata. 1989. «Contentious Traditions: The Debate on Sati in Colonial India». In: Recasting Women: Essays in Colonial History, edited by Kumkum Sangari and Sudesh Vaid, 88-126. New Delhi: Kali for Women.

Mazumdar, Vina. 1994. «Women's Studies and the Women's Movement in India: An Overview». Women's Studies Quarterly 22 (3/4): 42-54.

Mazumdar, Vina. 2007. «Emerging State Feminism in India: A Conversation with Vina Mazumdar, Member Secretary to the First Committee on the Status of Women in India». International Feminist Journal of Politics 9 (1): 104-111. DOI: https://doi. org/10.1080/14616740601066465.

McRobbie, Angela. 2009. The Aftermath of Feminism: Gender, Culture and Social Change. Los Angeles: Sage.

Mohanty, Chandra Talpade. 2013. «Transnational Feminist Crossings: On Neoliberalism and Radical Critique». Signs: Journal of Women in Culture and Society 38 (4): 967-991. DOI: https:/ doi.org/10.1086/669576.

Newman, Janet. 2017. «The Politics of Expertise: Neoliberalism, Governance and the Practice of Politics». In Assembling Neoliberalism: Expertise, Practices, Subjects, edited by Vaughan Higgins and Wendy Larner, 87-105. Palgrave Macmillan. DOI: https:/ / doi. org/10.1057/978-1-137-58204-1_5.

Pappu, Rekha. 2002. «Constituting a Field: Women's Studies in Higher Education». Indian Journal of Gender Studies 9 (2): 221-234. DOI: https:/ doi.org/10.1177/0971521502009 00206. 
Patel, Ila. 1998. «The Contemporary Women's Movement and Women's Education in India». International Review ofEducation 44 (2/3):155-175.DOI:https: / doi.org/10.1023 / A:10031 25808644 .

Radhakrishnan, Smitha. 2009. «Professional Women, Good Families: Respectable Femininity and the Cultural Politics of a 'New' India». Qualitative Sociology 32 (2): 195-212. DOI: https: / doi.org/10.1007/s11133-009-9125-5.

Ray, Raka. 1999. Fields of Protest: Women's Movements in India.. Minneapolis, MN: University of Minnesota Press.

Rege, Sharmila. 2013. Writing Caste/Writing Gender: Narrating Dalit Women's Testimonies. New Delhi: Zubaan.

Rottenberg, Catherine. 2018. The Rise of Neoliberal Feminism. New York: Oxford University Press.

Roy, Srila. 2009. «Melancholic Politics and the Politics of Melancholia: The Indian Women's Movement». Feminist Theory 10 (3): 341-357. DOI: https:/ doi.org/10.1177/146470010 9343257.

Roy, Srila. 2011. «Politics, Passion and Professionalization in Contemporary Indian Feminism». Sociology 45 (4): 587-602. DOI: https: / doi.org/10.1177/ 0038038511406584.

Roy, Srila. 2015. «The Indian Women's Movement: Within and Beyond NGOization». Journal of South Asian Development 10 (1): 96-117. DOI: https:/doi.org/10.1177/0973174114 567368.

Roy, Srila. ed. 2012. New South Asian Feminisms: Paradoxes and Possibilities. New York: Zed Books.

Sangari, Kumkum, and Sudesh Vaid. eds. 1990. Recasting Women: Essays in Indian Colonial History. New Delhi: Kali for Women.

Sharma, Kumud, Leela Kasturi, and Lotika Sarkar, eds. 2002. Between Tradition, Counter Tradition and Heresy: Contributions in Honour of Vina Mazumdar. Delhi: Rainbow Publishers.

Sharma, Kumud. 2017. «Towards Equality: A Journey of Discovery and Engagement». Indian Journal of Gender Studies 24 (1): 80-97. DOI: https: / doi.org/10.1177 / 09715215166 78535 .

Sreekumar, Sharmila. 2017. «Equivocations of Gender: Feminist Storytelling and Women's Studies in the Contemporary». Indian Journal of Gender Studies 24 (1): 47-68. DOI: https: / doi.org/10.1177/0971521516678531.

Tharu, Susie, and K. Lalita, eds. 1991. Women Writing in India: Volume I: 600 B.C. to the Early 20th Century. New York: Feminist Press at The City University of New York.

Tharu, Susie, and Tejaswini Niranjana. 1994. «Problems for a Contemporary Theory of Gender». Social Scientist 22 (3/4): 93-117. DOI: https: / doi.org/10.2307/3517624.

Twamley, Katherine, and Juhi Sidharth. 2019. «Negotiating Respectability: Comparing the Experiences of Poor and Middle-Class Young Urban Women in India». Modern Asian Studies 53 (5): 1646-1674. DOI: https: / doi.org/10.1017/S0026749X17000816.

Vijayakumar, Gowri. 2013. «'I'll Be Like Water': Gender, Class, and Flexible Aspirations at the Edge of India's Knowledge Economy». Gender \& Society 27 (6): 777-798. DOI: https: / doi.org/10.1177/0891243213499445.

Wilson, Kalpana. 2015. «Towards a Radical Re-Appropriation: Gender, Development and Neoliberal Feminism: Debate: Gender, Development and Neoliberal Feminism». Development and Change 46 (4): 803-832. DOI: https:/ doi.org/10.1111/ dech.12176.

Zalewski, Marysia. 2004. Feminism after Postmodernism: Theorising Through Practice. New York: Routledge. 
Cheshta Arora. PhD candidate at National Institute of Advanced Studies, Bengaluru, India. Her doctoral dissertation is an ethnographic study of women scientists, engineers and factory workers at three locations in India. The study is located at an intersection of feminist techno-science studies and labour studies. She is also interested in critical internet studies and urban studies.

Electronic address: cheshta@nias.res.in

Article received on the $30^{\text {th }}$ of June and accepted for publication on the $6^{\text {th }}$ of October 2020. 



\title{
FEMINISM AND/IN THE/ITS PLURAL
}

\author{
Begonya Saez Tajafuerce* \\ (D) https: / / orcid.org/0000-0001-7326-4478
}

\begin{abstract}
In recent times, Feminism has been declared a mass phenomenon, as if it thereby was attributed a plural character. Yet, what kind of plurality is at stake for the Mass as a subject? According to the philosophical notion of das Man, the Mass serves indifference, and it therefore stands as the paradigmatic subject of neoliberalism, fascism, and right-wing populism. The logic of the Mass is the logic of the One. Yet difference makes operative another logic, namely the logic of Plurality, a relational logic that allows for the new, the unexpected, and the improbable. Given its radically material and non-discursive complex character, the Body actualizes this true transformation by enacting sexual difference. By taking the Body into account, that is, by taking difference specifically into account, both in ontological as well as in epistemological and in ethico-political terms, Feminism might become an antidote to the totalitarian logic of the One.
\end{abstract}

Keywords: Feminism, neoliberalism, plurality, sexual difference, relationality.

\section{O Feminismo e/no/seu plural}

Recentemente, o Feminismo foi declarado um fenómeno de massas e parece que, dessa forma, se lhe atribui um caráter plural. Mas de que plural se fala quando o sujeito são as massas? De acordo com a noção filosófica de das Man, a Massa serve a indiferença e, portanto, assume o papel de sujeito paradigmático do neoliberalismo, do fascismo e do populismo de direita. A lógica da Massa é a Lógica do Um. Por contraste, a diferença torna outra lógica operacional, a lógica do Plural, uma lógica relacional que possibilita o que é novo, o inesperado e o improvável. Dado o seu caráter complexo, radicalmente material e não discursivo, o Corpo concretiza essa verdadeira transformação através da diferença sexual. Levando-se em conta o Corpo, isto é, tendo especificamente em conta a diferença, tanto em termos ontológicos quanto epistemológicos e ético-políticos, o feminismo pode-se tornar o antídoto contra a lógica totalitária do Um.

Palavras-chave: Feminismo, neoliberalismo, pluralidade, diferença sexual, lógica relacional.

\section{Resumen}

\section{El Feminismo y/en el/su plural}

Recientemente, el Feminismo ha sido declarado fenómeno de masas y pareciera que de ese modo se le atribuye un carácter plural. Pero, ¿de qué plural se hace cargo la masa

Department of Philosophy at Universitat Autònoma de Barcelona, 08193 Bellaterra, Barcelona, Spain.

Postal address: Edifici B, Carrer de la Fortuna, despatx B7/110, Campus de la UAB, 08193

Bellaterra, Barcelona, Spain.

Electronic address: Begonya.Saez@uab.cat 
como sujeto? A tenor de la noción filosófica de das Man, la Masa atiende a la indiferencia y por eso asume el papel de sujeto paradigmático del Neoliberalismo, del Fascismo y del Populismo de derechas. La lógica de la Masa es la Lógica del Uno. En cambio, la diferencia hace operativa otra lógica, a saber, la lógica del Plural, una lógica relacional que da lugar a lo nuevo, a lo inesperado y a lo improbable. Dado su complejo carácter radicalmente material y no discursivo, el cuerpo actualiza esta verdadera transformación mediante la diferencia sexual. Tomando en consideración el cuerpo, tomando en consideración la diferencia en su especificidad, tanto en términos ontológicos como también epistemológicos y ético-políticos, el feminismo puede llegar a ser el antídoto contra la lógica totalitaria del Uno.

Palabras clave: Feminismo, Neoliberalismo, pluralidad, diferencia sexual, lógica relacional.

In recent times, Feminism has been insistently declared a mass phenomenon in a wide variety of social and cultural milieux. Yet, what does such affirmation entail as regards the ethical and political challenges Feminism faces nowadays? Likewise, how does it determine not only the present but definitively also the future of Feminism in our capitalist world?

In order to address these questions, this paper aims at complexity. Already its title bears witness to complexity or, rather, to a specific complexity, conveying the need of stressing the importance and necessity of not simplifying Feminism inasmuch as simplification has proved to be one among the most efficient ideologically staged neoliberal political and economic strategies globally.

In this context, the reason I encourage complexity for Feminism and for any theoretical approach to it, is that complexity brings about an ethical and political opening, which Feminism should take on and hold on to. Hence, the main idea I would like to convey is this: let us not simplify Feminism. Or, in other words, let us not assume and comply with the discursive ideological strategy of simplification, the primary subject of which is indeed the Mass. At this point, I need to make clear that I shall render operative this category, the Mass, as one of the contemporary shapes of subjectivity, referring to a concrete philosophical tradition, entitled by Kierkegaard and Heidegger. They both discuss subjectivity in terms of the Mass or, in Heidegger's German, the well-known and impersonal das Man, or simply «man» (or «one») in English.

In $\S 27$ of Being and Time, devoted to the phenomenological analysis of Dasein as the Self in everyday life, Heidegger states that, in order to avoid the leveling dictatorship of das Man, care is required. Care is what makes being or Sein a Dasein. It is care which singularizes being. The $D a$ of Dasein designates therefore an affective condition of the presence of being. It does not simply designate presence or, to be even more precise, it does not designate presence simply understood in spatial and temporal terms. What is at stake here is not being as such - which would entail an ontological, ethical, and epistemological simplification -, but in 
more complex terms, what is at stake here is indeed the singularization of being by means of care, and not any kind of care but specifically «the care for difference - a distance - in front of the others.» This, I repeat, «the care for a difference in front of the others,» is what is required for being to be or, rather, to become, or even to become singularized as Dasein.

Now, let us go back to the consideration of Feminism as a mass phenomenon. In my understanding, Feminism consists, in a structural way, in desiring and daring to denounce simplification precisely as a discursive ideological strategy, which is that of das Man, and in taking hold of complexity as a modus operandi. A concrete example of this among many is diffraction, which is the discursive method both Donna Haraway and Karen Barad, situated in different disciplines, biology and quantum physics respectively, propose in an epistemological context in order to challenge reflection or its counterpart, refraction. Diffraction is concerned with difference and specifically with difference as a critical tool, as a method which allows for dealing with relationality as the main onto-ethico-epistemological condition. Whereas reflection tends to level knowledge, both its procedures and its results, the goal of diffraction is instead precisely to map the effects of difference or, in more technical terms, the effects of the material shaping of difference in, for instance, interference or interruption or suspension or the accidental or the event in, say, living processes.

Both the Dasein's care as existential structure and Haraway's and Barad's diffraction as a critical tool imply affection, and affection, I assert, is fundamentally linked to complexity. I will soon develop the issue of Feminism and affection. Yet, before that I would like to underline the idea I just mentioned, namely, that Feminism is and needs to be devoted to complexity as well as to reviling simplification. Feminism is and needs to be an antidote to simplification, and this implies that its relation to the Mass must be challenged, because the Mass or das Man, man or the «one», cannot fulfill such a task. Why is that so?

Why can the Mass not be - and, in my view, should not be - the subject of Feminism? I will maintain that there are three kinds of reasons for the Mass to be an inadequate or even an illegitimate subject of Feminism: there are ontological, epistemological, and ethico-political reasons. These reasons concern three existential axes, namely, being, knowledge, and action in the context of Feminism, and it concerns likewise the relations that we universally and singularly at once establish between them in order to bring consistency to our lives and world both in individual and in collective terms.

There is no doubt that today Feminism is a massive movement. Yet, is it a mass movement? This is another way of asking the question of the adequacy and of the legitimacy of the Mass as the subject of Feminism. In correspondence to the three existential axes mentioned above - being, knowledge, and action - I want now to point to three aspects that refer to the very nature of the Mass as a subject, namely: (1) the One, (2) Certainty, and (3) Perfection. Although I shall focus on the 
first aspect, that is, on the ontological determination of the Mass as the One, it is important to keep in mind that all three aspects are fundamentally interconnected, and that they support one another because they are structurally bound. They make the Mass, as apparatus, operative in the context of modern neoliberal states.

Thus, the One, Certainty, and Perfection express the main qualities of the Mass when comprehended from an ontological, epistemological, and ethicopolitical perspective, that is, from the point of view of our threefold existential axiology: being, knowledge, and action. This means that (1) the Mass is the One, fully and wholly constituted in terms of identity, and that it does not entail any reference to either alterity or difference. There is no Other in the horizon of the One. There is no Other for the One. Concomitantly, (2) the Mass does not engage in any kind of self-reflective procedure regarding the conclusions it reaches. The Mass does not step back to reconsider the outcome of any research it undertakes, and neither does it hesitate to apply the results it validates, and of course it does not doubt or question what it knows in the context of a radical subject-object relationship. Nothing breaks the Certainty of the Mass. (3) As to the third quality of the Mass as a subject, which refers to action from the point of view of Perfection, it implies that, as a matter of fact, no real action is taken by the Mass, since when perfection is given, no change applies. Hannah Arendt, who has elaborated on action from an ontological as well as from an ethico-political perspective in contemporary terms, clearly states that action - besides labor and work, the other two pillars of the human vita activa - refers to plurality. She makes clear that plurality is the condition for all political life as well as for the actualization of the capacity of freedom understood as the capacity of bringing about something radically new, something unexpected, a true beginning as a break. This is the reason why natality is the paradigm chosen by Arendt to explain action as the actualization of freedom. I shall come back to plurality below.

Action makes a difference also in the sense that it differentiates humans as such. Therefore, Arendt claims, true transformations - as opposed to «mere changes» - or «revolutions are the only political events which confront us directly and inevitably with the problem of beginning» (Arendt 1990, 21). Hence, in her view, which I fully subscribe here, action implies that initiative is taken to bring about that which is new understood as the improbable in life and in the world. In this respect, she writes: «It is the nature of beginning that something new is started which cannot be expected from whatever may have happened before. This character of startling unexpectedness is inherent in all beginnings and in all origins» (Arendt 1989, 178), and she specifies:

The fact that man is capable of action means that the unexpected can be expected from him, that he is able to perform what is infinitely improbable. And this again is possible only because each man is unique, so that with each birth something uniquely new comes into the world. (Arendt 1989, 178) 
The Mass lacks the capacity of bringing about that which is new, that is, it lacks the capacity for action - as well as the capacity for freedom - because it lacks uniqueness or, in other words, because it lacks singularity. The Mass is the One and this means that it entirely submits to the universal. This is precisely what structurally explains the banality of evil. The Mass is and remains indifferent to the question «Who are you»? (Arendt 1989, 178).

Forged in the ontological terms of the One, in the epistemological terms of Certainty, and in the ethico-political terms of Perfection, we see the Mass time and again operating in neoliberal configurations, in fascist congregations, and in rightwing populism. The subject underlying these forms of conservatism and, accordingly, of patriarchal capitalism, the subject in which they are grounded and literally find support is the Mass conforming to the qualities I have just mentioned. I recall Heidegger's reference to the «leveling dictatorship» of das Man.

What seems crucial here is that, as an embodiment of the One, as shaped in Certainty, as granted by Perfection, and as legitimated by all three, the Mass is and remains a static subject. This entails that the Mass does not allow for movement, for change, for transformation, for revolution. It is rather contrary to it all. It embodies, shapes, and grants the impossibility of it all or the impossibility of that what is new and unexpected, in Arendt's words. The Mass is the subject of any kind of totalitarianism. Therefore, it necessarily stands and falls as the paradigmatic subject of neoliberalism, fascism, and right-wing populism. Those are names for ontological, epistemological, and ethico-political staticism. Feminism, on the contrary, is and remains a movement, and I emphasize «movement» here. So the logic of Feminism should by no means coincide with, tend to or imitate the static logic of the Mass. Feminism does rather make this logic evident in everyday life ways of being, knowing, and acting, and opposes it.

Therefore, I insist, let us not simplify Feminism. Let us not reduce it to the One, to Certainty, and to Perfection. Let us instead dare complexity, and take on the challenge of Plurality, of Indetermination, and of Affection.

Plurality, Indetermination, and Affection are the conditio sine qua non of Feminism in our times and just like the One, Certainty, and Perfection, their counterparts, they are also fundamentally interconnected and they support one another because they too are structurally bound. The structure they conform to is relationality, understood as the ontological, epistemological, and ethico-political conditio sine qua non of existence. Hannah Arendt speaks of «the fact that men, not Man, live on the earth and inhabit the world» (Arendt 1989, 7). Yet, relationality is and needs to be at once a universal and a singular conditio sine qua non for existence, «because we are all the same, that is, human, in such a way that nobody is ever the same as anyone else who ever lived, lives, or will live» (Arendt 1989, 8). Therefore, relationality entails difference - or Plurality in Arendt's terminology. It entails a consideration of difference. It entails an observance of difference. In other words, 
recalling again Heidegger, relationality entails «the care for difference - in front of the others» as the conditio sine qua non to become singularized as a Dasein instead of just - indifferently - identified as the Mass.

Being women together was not enough. We were different. Being gay-girls together was not enough. We were different. Being Black together was not enough. We were different. Being Black women together was not enough. We were different. Being Black dykes together was not enough. We were different. Each of us had our own needs and pursuits, and many different alliances. Self-preservation warned some of us that we could not afford to settle for one easy definition, one narrow individuation of self (...) It was a while before we came to realize that our place was the very house of difference rather [than] the security of any one particular difference. (Lorde 1985, 226)

What does it imply for Feminism to take care of difference - in front of the others or, more specifically, to structurally take care of difference - in front of the others? Strictly speaking, what does it imply for Feminism to take care of difference not simply as an object, as a phenomenon, as a fact, that is, as applying inequality in all domains of existence, but to take care of difference as an ontological, epistemological, and ethico-political condition of Feminism itself? What does it imply for Feminism to conform to difference? I suggest that one way to take on these questions is by referring to plurality in the context of the threefold existential axis I just mentioned: Plurality, Indetermination, and Affection.

In what follows, I will pursue a brief approximation to the complexity that concerns Feminism by referring to the way in which it deals with difference as plurality. Feminism is and should not be one Feminism but plural Feminisms. Feminism is and should be plural as opposed to the One. Engaging with difference in terms of plurality should determine not only the being of Feminism but equally the way in which Feminism deals with knowledge via indetermination and the way it engages in action via affection.

In this respect, taking into account this complexity as structural, the question, in Arendtian terms, is how might Feminism not only allow but firmly stand as the possibility for that which is new, the unexpected, the improbable to become, or how might Feminism allow and firmly stand as the possibility for an ontological, epistemological, and ethico-political opening. How might Feminism take on this fundamental task understood as an antidote to the task constantly fulfilled by the Mass? We know that this task requires Plurality since only Plurality allows and firmly stands as the possibility for movement, change, transformation, and indeed revolution, thus not «a mere change».

Now, to what extent is Feminism willing to acknowledge itself in difference? To what extent is Feminism committed to the care for difference - in front of others? To what extent is Feminism devoted to claiming difference as modus operandi? To what extent is Feminism ready to split into Feminisms and give up the One for 
good? These questions might seem banal to a certain point, or even anachronistic. We all do recall that two and a half decades ago, in 1993, Linda Alcoff and Elizabeth Potter edited Feminist Epistemologies. Thinking Gender. In their introductory article to the volume, titled «When Feminisms Intersect Epistemology», they state:

For feminists, the purpose of epistemology is not only to satisfy intellectual curiosity, but also to contribute to an emancipatory goal: the expansion of democracy in the production of knowledge. This goal requires that our epistemologies make it possible to see how knowledge is authorized and who is empowered by it. It follows that feminist epistemologies should be self-reflexive, able to reveal their own social grounds, a revelation made all the more urgent because academic feminists are in a contradictory social position, seeking fundamental changes in the very institutions that empower us to speak and work. (Alcoff \& Potter 1993, 13-14)

In my understanding, what Alcoff and Potter are asking for is caring for difference so that a difference is made there where difference seems to have no place, there where difference is improbable, namely in the production of knowledge. Difference is requested as an antidote - beware, not to objectivity, but to Certainty, which holds together the one Epistemology grounded in Metaphysics and in the paradigm of modern rationalist and positivist science.

Alcoff and Potter clearly establish a link between the ontological, the epistemological, and the ethico-political aspects and consequences that Feminism and/in the/its plural opens up when the challenge thereby implied is assumed.

To raise a question regarding Feminism and the plural shows both the desire and the need for a plural conceptualization of Feminism.

To situate Feminism in the plural implies a claim for a plural articulation of Feminism.

To stress a look at Feminism and its plural speaks of the will to recognize what kind of relation Feminism is able to establish to the plural or to what extent Feminism is open to become plural.

Finally, to ask about Feminism in its plural entails the challenge to find the way for Feminism to look for its specific plural, to specifically care for it and stand by it. The quest for complexity as an antidote against simplification runs parallel to the quest for specificity. In my opinion, the specific plural of Feminism by means of which difference and the care for difference most radically applies points at the Body. I shall dwell upon the Body and its role regarding the specificity of difference, to which I am referring here, in the forthcoming paragraphs. However, I want to underline with no further delay that difference operates as a structure at very different levels, yet always in material terms in that - as we have learned from Black and Post - and Decolonial, but also Marxist Feminisms - difference primarily concerns the material conditions of the lives of the subjects. Therefore, I suggest, difference cannot - and should not - be reflected upon without the Body. 
It goes without saying that Plurality is and remains a challenge for nowadays Feminism. Caring for difference brings Feminism on the stands of Plurality. I suggest that we briefly pay attention to what I take to be the main ways in which this challenge conforms itself as ways of caring for difference and standing for transformation, including self-transformation. Univocal signification, hegemony, and self-affection comply with the logic of the Mass. I believe that by taking on the challenge of Plurality, univocal signification becomes ambiguity, hegemony becomes contingency, and self-affection becomes hetero-affection. Let us try to go one by one through each transformation. Nonetheless, let me just note that Feminism is hereby facing a structural transformation, meaning thereby that a logic, as I already brought attention to, namely, the static logic of the One, undergoes thereby transformation as well.

The logic of the One, of the Mass, is fundamentally an all-encompassing or literally totalitarian logic of calculation, of measure, and of control. Feminism and/ in the/its plural brings about a new logic or, rather, it brings about that which is new into logic, the unexpected, the improbable, and therein lies the transformative power of Feminism, which indeed enables and enacts the power of difference. In this way, Feminism brings about a change of paradigm just as Quantum Physics actualizes by means of uncertainty, superposition and entanglement as its main operative principles, a change of paradigm in the realm of Science in relation to classic Physics.

Now, in the context of Feminism today, what does the transformation of univocal signification into ambiguity entail and bring about? What does the transformation of hegemony into contingency entail and bring about? Finally, what does the transformation of self-affection into hetero-affection entail and bring about?

We need to look at the Body in order to take on these questions. We need to look at the Body since the Body is at once the discursive and the material site of difference understood as an embodied and non-dialectical tension, therefore not fully mediated, between the universal and the singular. We need to look at the Body in order to make operative difference as sexual difference. The Body, I state, paradigmatically performs Plurality in the terms Hannah Arendt points out, that is, as a structural discrepancy within sameness, since we humans are, in her view, the same and uniquely never the same at once. This structural discrepancy is what the Body paradigmatically enacts by the work of sexual difference, that here can be understood as an operation of an ontological, epistemological, and ethico-political scope and significance.

In «Bodies and Knowledges: Feminism and the Crisis of Reason», included in Feminist Epistemologies. Thinking Gender, Elizabeth Grosz points out the ontological, epistemological, and ethico-political need to take into account what she names as «explicit sexualization of knowledge» (Grosz 1993, 187). This is relevant in order to make evident that knowledge is partial and not neutral even if, as it usually is 
maintained in the name and for the sake of objectivity, it is articulated according to the parameters of instrumental or enlightened rationality, which, as we know since Descartes, dismisses the Body, the res extensa, as a source of Certainty. However, Grosz is not - as it is the case with Judith Butler - referring to the Body from the point of view of gender, a point of view that offers, as we know, an exclusively discursive approach to the Body. In Elizabeth Grosz's view, sex, that is, sexual difference, is the reference, yet a non-discursive reference, since it becomes a rationale of its own, a radically singular rationale by means of which the new, the unexpected, and the improbable that only the Body brings about, transforms neutrality in ontological, epistemological, and ethico-political terms.

Feminism is thereby encouraged to render operative sexual difference as rationale, the main operation of which is none other than precisely difference, the actualization, that is, the materialization, time and again, of difference. This situates us in a radically other form of logic than the logic of the One, which is, as mentioned previously, a logic of calculation, of measure, and of control.

We are little by little touching upon the complexity of Feminism I have approached at the beginning of this paper. The title of the paper, I have stated, bears witness to complexity. Indeed, it bears witness to the complexity of this other logic, this radically singular rationale that is sexual difference and to the challenge therein implied.

(1) Univocal signification - ambiguity (plurality)

For how is it possible to renounce to univocal signification, or even to critically speak out against it, to devote enunciation to ambiguity, and yet still have an effect on society? How is it possible to honor the plural, and this means to honor every single one of the differing voices of Feminism, and still contribute to activism? Furthermore, how is it possible to explicitly avoid mediating other voices and still stand up against injustice, discrimination, exclusion, exploitation, etc.? I refer here to the challenge Gayatri Spivak posed to white European Feminism already in 1988 with her article «Can the Subaltern Speak?», but also to the new methodological frame which Kimberlé Crenshaw introduced one year later, in 1989, with her notion of intersectionality, just to mention two well-known critical approaches of univocal signification. I am also thinking of a debate which took place several years ago in Barcelona and in Spain about the legalization of sexual work and, specifically, about the creation of a trade union for female sex workers which would allow them to visibly fight for their social rights.

Is there one voice of Feminism? Furthermore, to phrase it more dramatically, is there one single entitled voice of Feminism? To my understanding, what these women, what these feminists, among others, make evident is that there is no such thing as a single entitled voice of Feminism, nor should there be. In other words, there is not a true Feminism, a source of legitimacy, by means of which a kind of original essence is kept as a treasure in a saving box. Feminism is a movement; it 
is a collective movement, a deeply heterogeneous movement. Feminism is a flux, a running and changing river, a coincidence of a variety of intensities, and this means that it differs from within, intrinsically, and that, at the same time, it differs from other movements which are fundamentally based in the One, this One being for instance individual rights. This all means that, to renounce critically to univocal signification implies that mutual belonging and interdependency shape the discourse as well as the action of Feminism, and that no hierarchy is hereby at work nor allowed. It is from this anti-hierarchical perspective that I agree with Judith Butler, among many other voices now, when she claims that transphobic Feminism is no Feminism. Because transphobic Feminism does not care for transrealities in the sense that it does not care for difference and that it does not stand by it.

(2) Hegemony - contingency (indetermination)

It seems rather obvious that the disavowal of univocal signification as a regulatory operation of enunciation that allows for a hierarchical legitimation of a particular discourse above others implies the destabilization of hegemony understood as institutionalized power supremacy. Therefore, as Gramsci pointed out, in any political scenario, the fight for power entails a hegemony contest, which is driven by the dissemination of, and later consent to, ideas that sooner or later become commonsensical and, thereby, become an obstacle for other ideas to evolve and shape the political arena.

What is interesting here, because it makes evident that Feminism indeed cares for difference as rationale, is that the destabilization of hegemony - maybe this would be a way of conceptualizing revolutions in contemporary terms - does not need to be carried out in order to win it, and consequently to tip over into a new hegemonic position. In my opinion, Feminism does not claim hegemony for itself when it engages with difference. An example of this is the movement Marea Verde in Argentina, leading the demand for free abortion in the country, or the newest feminist wave in Chile, denouncing the silenced and reiterated patriarchal abusive practices of harassment in higher education centers all over the country that we saw in full action in the summer of 2018. Both feminist initiatives clearly acted upon structural patterns of what we know as capitalist patriarchy in Silvia Federici's terminology. Yet neither one claimed a hegemonic position. This implied, for instance, that they did not take a formal step into institutionalized politics they did not conform to any political party - and they were highly and broadly criticized for not doing so even by supposedly progressive female politicians.

When difference matters, difference instead of this or that idea, difference instead of this or that individual, difference instead of this or that right or all along with all of it in a structural way; when difference leads the fight, the fight for that which is new, for the unexpected, for the improbable, then hegemony is ruled out. Contingency, on the other hand, is fully operative. 
Hannah Arendt understands action, political action, transformative action, in terms of unpredictability, which is related to contingency in the sense that it binds action to a logic where calculation, measure, and control are also ruled out. In this respect, she writes: «The reason why we are never able to foretell with certainty the outcome and end of any action is simply that action has no end» (Arendt 1989, 233). Action escapes the logic of causality because it is «boundless», she states. Therefore, «the smallest act in the most limited circumstances bears the seed of the same boundlessness, because one deed, and sometimes one word, suffices to change every constellation» (Arendt 1989, 190).

What matters is to allow difference to evolve and shape the political arena, in a way that the new, the unexpected, and the improbable happen and literally take place.

(3) Self-affection - hetero-affection (affection)

Affection has become a gigantic issue for Feminism in the recent times. It is not my purpose here to go through the significant variety of forms it has taken in the relatively recently named affect theory. Yet what is common to all of those forms is that they expand on Spinoza's - the $17^{\text {th }}$ century outsider philosopher - understanding that affects and action condition one another. Action derives in any living being from affection because all living beings strive after perseverance. Spinoza understands that affection provides all living beings with a power - potentia - that enables them to act, and the fundamental power all living beings are endowed with is precisely the power to persevere. Spinoza names this power conatus. The main point here is that Spinoza allows for the new, the unexpected, and the improbable to take place in philosophical discourse in the context of Ethics as the ruling force of action. This calls us into a very different scenario than the one Descartes built for the res cogitans. It also calls us into a very different scenario than the one occupied by the Mass, since the Mass is affectless, or, rather, indifferent, just like das Man as opposed to Dasein, since, according to Heidegger, the existence of Dasein structurally rests on care. Care is indeed the main existentiary in Sein und Zeit.

Now, if we agree that Feminism cares for difference, for sexual difference as the radical expression of a difference - a distance - «in front of the others», in Heideggers's words, then we can affirm that Feminism is an affective movement in the sense that it is a movement of affects. Feminism allows for a circulation of affects, a plurality of affects inasmuch as it allows, as we have seen, for a plurality of voices and for a plurality of causes. Yet, what is relevant here is that difference is and remains cared for. This means that difference, that is, the material and nondialectical tension it consists of, remains as such inasmuch as the other remains as such or as singularity remains as such. Mediation does not occur and the other, the other affect, the other voice, the other cause remains other, remains in difference. Self-affection is not without the other, without the affection by the other, and without this affection remaining other. There is no affection without a structural 
distance, no care without a structural difference. This is how affection is and remains hetero-affection, and it is also how Feminism avoids indifference.

In my view, the challenge for Feminism is and remains to persevere in the commitment to allowing the movement to differentiate from itself, to persevere not simply in the plural, but singularly in its plural.

From the point of view of hetero-affection, but also from the point of view of ambiguity and contingency, the challenge of difference for Feminism has ontological, epistemological, as well as ethico-political consequences of great relevance. Not only because collective action becomes detached from a universal or general ideal or expectation, from a universally valid rule or program, which, for instance, in terms of decolonizing Feminism proves to be crucial, but even more strongly, because it makes Feminism at once familiar and strange to itself.

I agree with Teresa De Lauretis when she underlines in an article published in 1990 and entitled «EccentricSubjects: Feminist Theory and Historical Consciousness» that dealing with difference - she speaks of self-criticism - results in a permanent exile, since the subject is obliged to renounce to a «home.» I find her observation very similar to the former quotation by Audre Lorde about «the house of difference.» Difference happening, taking place, materializing in discourse, leads Feminism to abandon "physically, emotionally, linguistically, and epistemologically - that home - for some other unknown and risky place, which is not other only emotionally but also conceptually, for a discursive place from which talking or thinking is tentative, insecure and with no guarantee» (De Lauretis 1990, 138). What De Lauretis is describing here, in tune with Arendt's revolution, is a radical experience of permanent «dis-identification» (De Lauretis 1990,139) as the key experience or even as the experience sine qua non for the ongoing transformation, first of all, of Feminism itself.

\section{References}

Alcoff, Linda, and Elizabeth Potter (eds.). 1993. Feminist Epistemologies. Thinking Gender. London: Routledge.

Arendt, Hannah. 1989. The Human Condition. Chicago. The University of Chicago Press.

Arendt, Hannah. 1990. On Revolution. London: Penguin Books.

Crenshaw, Kimberlé. 1991. «Mapping the Margins: Interseccionality, Identity Politics, and Violence against Women of Color.» Standford Law Review, 43: 1241-1299.

De Lauretis, Teresa. 1990. «Eccentric Subjects: Feminist Theory and Historical Consciousness.» Feminist Studies 16(1): 115-150. DOI: 10.2307/3177959

Grosz, Elizabeth. 1993. «Bodies and Knowledges: Feminism and the Crisis of Reason.»In Feminist Epistemologies. Thinking Gender, edited by Linda Alcoff and Elizabeh Potter, 187-216. London: Routledge.

Heidegger, Martin. 2010. Being and Time. Translated by Joan Stambaugh, revised by Dennis J. Schmidt. Albany, New York: SUNY Press. 
Lorde, Audre. 1985. Zami: A New Spelling of my Name. New York: Quality Paperback Book Club.

Spivak, Gayatri. 1988. «Can the Subaltern Speak?» In Marxism and the Interpretation of Culture, edited by Cary Nelson and Lawrence Grossberg. London: Macmillan.

Begonya Saez Tajafuerce. Professor of Philosophy at the Universitat Autònoma de Barcelona and, since 2005, member of the Group Body and Textuality at the same university. Since 2001, her research has focused on identity in contemporary terms. She works on feminist approaches to the Body from a relational standpoint and from an ontological, epistemological, ethical and political perspective. The following are some of her most recent publications: Debats: Un corpus para el cuerpo (2013), Cuerpo, memoria y representación: Adriana Cavarero y Judith Butler en diálogo (2014) y Feminismos en la era del algoritmo (2019).

Electronic address: Begonya.Saez@uab.cat

Article received on the 17th of July and accepted for publication on the 7th of October 2020. 



\title{
ACADEMIAS DE TALENTO FEMININO: MEIOS DE EMANCIPAÇÃO OU FERRAMENTAS DE REPRODUÇÃO SOCIAL? ${ }^{1}$
}

Susana Santos*

(D) https: / / orcid.org/0000-0001-5225-6671

\section{Resumo}

Os programas de promoção do talento e liderança direcionados a mulheres têm-se desenvolvido nos últimos anos e acompanham os debates mais alargados sobre a igualdade de género, as diferenças salariais e a conciliação entre trabalho e vida familiar. As sociedades de advocacia, pelo seu carácter internacional e de grande permeabilidade aos discursos na esfera económica global, são um excelente objeto de observação.

Neste artigo, problematizam-se as interseções entre feminismos e neoliberalismo, em especial o feminismo neoliberal e o feminismo transnacional de negócios a partir da observação sociológica da cultura organizacional das sociedades de advocacia de grande dimensão em Portugal.

Palavras-chave: academias de talento feminino; liderança; feminismo neoliberal; feminismo transnacional de negócios; sociedades de advocacia.

\begin{abstract}
Feminine Leadership Academies: emancipation forms or social reproduction mechanisms?

Programs for the promotion of talent and leadership aimed at women have been developed in recent years and accompany the broader debates on gender equality, wage gender gaps and work-life balance. Law firms are an excellent object of observation due to their international atmosphere and their high permeability to discourses in the global economic sphere.

This article discusses the intersections between feminisms and neoliberalism, in particular, neoliberal feminism and transnational business feminism based on sociological observation of the organizational culture of large law firms in Portugal.
\end{abstract}

Keywords: Feminine talent academies; leadership; neoliberal feminism; transnational business feminism; law firms.

Duas versões preliminares foram apresentadas na XIX Conferência Mundial da Associação Internacional de Sociologia (ISA), que decorreu em Toronto, de 15 a 21 de julho de 2018, com o título «Work-Life Balance in Large Law Firms: A Case Study on Young Female and Male Lawyers» e na conferência internacional «Mulheres, Mundos do Trabalho e da Cidadania», organizada pelo Dinâmia'CET-IUL, que decorreu em Lisboa, no ISCTE-IUL, a 6 e 7 de dezembro de 2018, com o título «Grandes sociedades de advocacia enquanto organizações genderizadas: análise dos impactos na socialização e integração profissional de jovens advogadas/os».

Cies.Iscte, Instituto Universitário de Lisboa, 1649-026 Lisboa, Portugal.

Endereço Postal: Avenida das Forças Armadas, 1649-026 Lisboa, Portugal.

Endereço eletrónico: susanacsantos@iscte.pt 


\section{Resumen}

Academias de Talento Femenino: ¿formas de emancipación o mecanismos de reproducción social?

Los programas para la promoción del talento y el liderazgo dirigidos a las mujeres se han desarrollado en los últimos años y acompañan los debates más amplios sobre igualdad de género, diferencias salariales y la conciliación de la vida laboral y familiar. Los despachos de abogacía, debido a su carácter internacional y su alta permeabilidad a los discursos en la esfera económica mundial, son un excelente objeto de observación.

Este artículo analiza las intersecciones entre feminismos y neoliberalismo, en particular, el feminismo neoliberal y el feminismo empresarial transnacional basado en la observación sociológica de la cultura organizacional de las grandes oficinas de abogacía en Portugal.

Palabras-clave: Academias de talento femenino; liderazgo; feminismo neoliberal; feminismo empresarial transnacional; despacho de abogacía.

\section{Introdução}

A liderança no feminino tem sido muito discutida em fóruns nacionais e internacionais, impulsionada por debates mais alargados sobre a igualdade de género, as diferenças salariais e a conciliação entre trabalho e vida familiar. As sociedades de advocacia, ${ }^{2}$ pelo seu carácter internacional e de grande permeabilidade aos discursos na esfera económica global, são um excelente ponto de observação sociológica.

Este artigo pretende problematizar as ligações entre o(s) movimento(s) feminista(s) e o neoliberalismo - a partir da leitura de diversas feministas críticas - e a pesquisa empírica em grandes sociedades de advocacia.

Os programas de formação direcionados em exclusivo às mulheres estão a produzir efeitos? E que tipo de efeitos? Como responde a cultura organizacional?

$\mathrm{O}$ material aqui apresentado foca-se nas atividades desenvolvidas pelas sociedades de advocacia sob o chapéu da diversidade e inclusão, como a flexibilidade de horário e local de trabalho e as academias de talento feminino.

Para tal, foi realizado um conjunto de nove entrevistas a advogadas nos primeiros dez anos de carreira e selecionado um conjunto de documentos produzidos pelas sociedades de advocacia.

A expressão utilizada pelo meio da advocacia é sociedade de advocacia, colocando a referência masculina como universal. Ao longo do texto, e com exceção dos excertos das entrevistas, adota-se uma linguagem inclusiva de acordo com a linha editorial da revista. 


\section{Feminismo neoliberal, popular, pós-feminismo e feminismo transnacio- nal de negócios}

A questão da liderança no feminino e da escassez de mulheres em cargos de topo nos setores público e privado ${ }^{3}$ é indissociável da capacidade de agendamento público do movimento feminista. O debate dos últimos anos tem sido profícuo na criação de termos que pretendem descrever o momento atual, os seus impasses e desafios, apontando ao mesmo tempo novos caminhos. Detenhamo-nos sobre a descrição das dinâmicas sociais entre os movimentos feministas e o modo de organização social prevalecente, isto é, entre feminismos e neoliberalismo. Entende-se neoliberalismo como uma racionalidade política dominante capaz de aplicar a racionalidade de mercado e a sua linguagem de ativos, ganhos, eficácia e eficiência em todas as esferas da vida, incluindo a vida privada (Banet-Weiser, Gill e Rottenberg 2019).

O feminismo neoliberal apropria-se dos conceitos-chave do feminismo - a emancipação, a igualdade - mudando-lhes o significado e introduzindo uma lógica mercantilista na conformação das subjetividades, extraindo-lhes o potencial de transformação social (Rottenberg 2017). A luta por conquistas coletivas é transformada num caminho individual de superação de obstáculos em que o centro da ação é a pessoa capaz de controlar e assumir riscos, ser empreendedora e em que o espaço social é ocupado por um grupo minoritário de mulheres que ascende ao topo profissional à custa do trabalho de mulheres invisíveis e indiferenciadas (Elias 2013). O sucesso profissional é projetado a partir de uma planificação cuidadosa da carreira para assegurar a maior rentabilidade futura baseada na escolha e responsabilidade individual, em processos individuais de tomada de decisão onde a desigualdade de género é um obstáculo a ultrapassar. Exemplo preocupante e extremo é a oferta de serviços de saúde de congelamento de óvulos ou de tratamentos de fertilidade (Kohll 2019) como forma de compensar as funcionárias pelo forte investimento na carreira profissional.

Outro ponto de entrada no debate é através da conceptualização do feminismo mainstream (McRobbie 2009) ou popular (Banet-Weiser 2018). Os media digitais, o cinema comercial, as plataformas de streaming assumem o lugar para a criação sobre temas feministas, concedendo visibilidade que gera retorno através da publicitação do feminismo como um novo modo de consumo, o feminismo como marca, das t-shirts de Frida Kahlo às frases que se tornaram populares em

\footnotetext{
O EIGE - Instituto Europeu para a Igualdade de Género compila os dados relativos à liderança através dos indicadores: mulheres com lugares de CEO, executivas e não executivas em empresas cotadas em bolsa na Europa, em Portugal o índice PSI 20. No primeiro semestre de 2020, em Portugal e na UE a 27 respetivamente: CEO 5,9\% (8,2\% na UE-27), executivas 15,5\% (18,8\%), não executivas 31\% (31\%). Disponível em: https: / / eige.europa.eu / gender-statistics/dgs/indicator / wmidm_bus_bus_wmid_comp_compex/datatable. Último acesso a 24 de junho de 2020.
} 
marcas como a Zara, ${ }^{4}$ dirigidas ao grande público a preços acessíveis, à afirmação de figuras públicas e celebridades como feministas (Banet-Weiser, Gill e Rottenberg 2019).

O feminismo espetacular das celebridades aliado ao feminismo empresarial publicita e, em simultâneo, invisibiliza as desigualdades, contribuindo para uma naturalização que não ataca as estruturas patriarcais da sociedade. Mulheres como Sheryl Sandberg, chefe operacional do Facebook, são presença nos grandes fóruns internacionais (Davos, Web Summit, etc.), apresentando-se como feministas e defendendo a ideia de que a sua presença no espaço público as coloca no papel de porta-vozes das mulheres (Rottenberg 2014). O seu papel de porta-voz é evidenciado pela publicação de manifestos feministas que rapidamente se transformam em bestsellers. Da análise desses manifestos (Banet-Weiser, Gill e Rottenberg 2019) resulta uma imagem do feminismo como estando em sintonia com a ideologia neoliberal, onde são realçados o sucesso económico, o autocuidado e a conciliação trabalho-família-vida pessoal inseridos numa tendência cultural mais vasta de apologia da felicidade (Rottenberg 2014).

A ideia de felicidade parte da reflexão sobre os riscos de carreiras profissionais diminuídas por conta da maternidade (mummy track), que tem colocado as mulheres perante o dilema «carreira ou família», contrapondo ao ideal de supermulher a de balanced woman que pode optar por uma trajetória profissional não-linear com momentos de investimento diferenciados. A promoção deste tipo de escolhas não tem em consideração a situação profissional e financeira da maioria das mulheres, resultando num projeto feminista elitista que não produz alternativas ao modelo de divisão sexual do trabalho.

Outro exemplo dessa convergência é o destaque dado às mulheres em lugares de poder em instituições nacionais e supranacionais, as femocratas, que atuam como forças sociais legitimadoras do pensamento e ação neoliberal (Roberts 2012; Elias 2013). Nancy Fraser define a corrente progressista neoliberal que esteve por detrás da campanha presidencial de Hillary Clinton como um oximoro (Fraser 2016), no sentido em que aglutina duas forças sociais opostas, de um lado representantes do movimento feminista, do outro lado o capitalismo cognitivo de Wall Street, Silicon Valley e Hollywood. Esta chamada de atenção vem acompanhada de uma proposta feminista que combina as políticas de reconhecimento com as políticas de redistribuição (Fraser 2016) garantindo o carácter emancipatório, intersecional e inclusivo do movimento.

O momento atual beneficia de diferentes dinâmicas convergentes, ou de um pós-feminino de dupla ação (McRobbie 2009) em que os discursos feministas ganham capacidade de se incorporar nas agendas políticas e institucionais, sendo em simultâneo moldado pelas instituições. O resultado é contraditório. A incorporação de temas feministas, em particular a igualdade de género e a liderança no

4 https://www.saberviver.pt/moda/13-t-shirts-feministas-a-apostar. 
feminino, são acompanhadas por formas ativas de despolitização e de essencialização de determinadas categorias e de processos de invisibilização de classe, raça e nacionalidade (Elias 2013).

As iniciativas empresariais partem da ideia de que as mulheres e o espaço doméstico são uma importante oportunidade de negócio e de expansão dos mercados (Goldman Sachs 2009) com a criação de novos serviços pagos, terciarização de funções, criação de novos seguros e comodificação de atividades. O argumento principal desenvolvido pelo gabinete de estudos da Goldman Sachs é que o investimento em mulheres (plataformas de crédito, educação e saúde) é de extrema importância para o desenvolvimento económico e para a expansão das classes médias, em particular nos países BRICS 5 .

Adrienne Roberts (2012) define este tipo de atividades de empoderamento feminino como feminismo transnacional de negócios. O argumento principal surge da forma como a masculinidade de negócios transnacional foi abalada com a crise económica de 2008. No espaço público, foi crescendo a ideia de que são necessárias mulheres em cargos de decisão ${ }^{6}$ e de poder para equilibrar as tensões e a errância masculina, prevenindo assim futuras crises económicas (Roberts 2012, 90). Os argumentos referem as características biológicas, que se manifestam em diferentes traços de personalidade - o mito do género (Elias 2013), com a testosterona associada à agressividade e competição no masculino e o estrogénio ao trabalho de equipa e à aversão ao risco no feminino, a ideia do asset-to estrogen ratio. A maior sofisticação dos argumentos, importando de forma seletiva conhecimento científico, prossegue a estratégia essencialista e reprodutora de estereótipos.

Maria Medina-Vicent (2019) estudou a liderança feminina e o modelo da mulher líder a partir da literatura de gestão especializada. A autora concluiu que o modelo de liderança no feminino é um modelo essencialista, reprodutor de dicotomias de género e com base na racionalidade do homo economicus. Este modelo é apresentado em vários livros de gestão que colocam o problema do número diminuto ou inexistente de mulheres em cargos de topo como um problema individual. A autora sublinha o carácter psicológico das obras, o seu estilo de autoajuda, aspiracional, aliás já identificado por outros autores (Boltanski e Chiapello 1999). A mudança deve ocorrer no interior do indivíduo que se deve superar, vencer os desafios, numa tónica despolitizada e de negação de conflitos. Questões como a maternidade, a conciliação, a igualdade salarial ou a progressão na carreira são apresentadas como momentos de autossuperação.

Acrónimo para Brasil, Rússia, Índia, China e África do Sul.

Ainda recentemente esse argumento foi utilizado a propósito da pandemia COVID-19 e o papel das governantes mulheres (Wittenberg-Cox 2020). 


\section{Sociedades de advocacia: genderização, divisão sexual do trabalho e competição individual}

As grandes sociedades de advocacia são organizações complexas, altamente estratificadas que se posicionam no mercado internacional da prestação de serviços jurídicos (Dezalay e Sugarman 1995). As/os suas/seus profissionais movem-se num mundo global (Faulconbridge e Muzio 2008, 2012) competitivo e diverso. Esta diversidade tem impacto nos processos de seleção e recrutamento das advogadas e dos advogados (Santos 2017, 2018), com uma crescente preocupação de abertura às mulheres, às minorias étnicas, à integração de imigrantes, indo ao encontro das novas especificidades da atividade cada vez mais pautada pelos interesses dos clientes numa ótica do profissionalismo comercial (Hanlon 1998).

No entanto, estas transformações coexistem com desigualdades persistentes e historicamente situadas, como o tardio acesso das mulheres à advocacia ${ }^{7}$, a sua dificuldade em chegar a lugares de topo (Bolton e Muzio 2007) e ainda a contínua reprodução social da imagem do homem branco de classe média como o protótipo do advogado nas sociedades ocidentais (Wilkins e Gulati 1996).

A organização do trabalho, a construção das equipas, a divisão do trabalho, a ocupação dos espaços físicos são processos dinâmicos onde podem ser observadas formas de genderização. Joan Acker define o processo de genderização no interior das organizações como a «vantagem e desvantagem, exploração e controlo, ação e emoção, sentido e identidade moldados em torno de distinções entre homem e mulher, masculino e feminino?» (Acker 1990, 146) que podem ser encontradas na divisão de tarefas, na ocupação dos espaços físicos e nos comportamentos aceites. As questões relativas ao espaço físico ocupado por cada profissional remetem para a relação com a divisão sexual do trabalho e para a prevalência de ocupações femininas e masculinas (Larson 1977).

A genderização das grandes sociedades não corresponde apenas à divisão hierárquica entre a advocacia nas várias posições de carreira, mas de igual modo aos departamentos de suporte, que, em algumas sociedades, têm um número elevado de pessoal técnico de apoio e onde se denota um claro predomínio de mulheres em funções. Existe então uma estratificação ocupacional e por sexo. O número de mulheres em posições de suporte nas sociedades de advocacia perpetua um conjunto de disposições relativas à subordinação das mulheres e ao reforço do seu papel de cuidadoras. Jennifer Pierce explora essas diferenças, assinalando que nas representações das advogadas e dos advogados existem formas de complementaridade nos papéis desempenhados por homens e mulheres que correspondem à ideologia de género cristalizada na ideia de que «as mulheres não possuem um

A primeira mulher a exercer advocacia em Portugal, Regina Quintanilha, iniciou a sua atividade em 1913 e só em 1918 é publicado o decreto n. ${ }^{\circ}$ 4676, de 19 de julho, que permite às mulheres o exercício da profissão. 
instinto assassino para serem advogadas e os homens não possuem as competências sociais para o trabalho paralegal» ${ }^{8}$ (Pierce 1996, 26). Num estudo mais recente sobre o setor financeiro na City de Londres, Linda McDowell (2010) identificou dois padrões de comportamento masculino: os patriarcas - homens mais velhos, racionais e poderosos - e os corretores - homens mais jovens com uma masculinidade exuberante e agressiva, barulhentos e expressivos, com uma confiança heterossexual.

Uma das questões importantes é a de percecionar se a criação de mecanismos de formação direcionados em exclusivo às mulheres, como as academias de talento feminino, estão a produzir efeitos e que tipo de efeitos.

Outra questão importante prende-se com a cultura organizacional das sociedades de advocacia. Nas últimas décadas assistiu-se à promoção da cultura empresarial (Galanter e Henderson 2008), com a divisão das sociedades de advocacia em departamentos autónomos financeiramente, geridos por sócios que acumulam funções de advocacia com a gestão financeira e de pessoal e que são responsáveis pela apresentação de resultados nas assembleias anuais perante o conselho de administração. Cada departamento compete por recursos e, no interior do departamento, cada advogada/o compete para assegurar a promoção ou a manutenção na carreira. Os planos de carreira são delineados tendo em conta um conjunto de parâmetros de avaliação (horas faturáveis, angariação de clientes, formação especializada, participação na vida da sociedade, ensino) e hierarquizam as advogadas e os advogados em cinco a seis categorias (estagiário/a, associado/a, associado/a sénior, associado/a principal, sócio/a de indústria e sócio/a de capital).

Walsh aponta que sociedades que promovem a flexibilidade nos horários, que contam com um maior número de sócios/as e que têm sócias são aquelas que mais promovem oportunidades de promoção na carreira para mulheres ou, de outra forma, que promovem igualmente mulheres e homens (Walsh 2012, 520). No entanto, a autora sublinha que as mulheres que pretendem chegar a sócias são aquelas que dedicam longas horas de trabalho à sociedade, apresentam um total compromisso com a profissão mas que, ainda assim, são consideradas como menos capazes de possuir os requisitos necessários para o sucesso (Walsh 2012, 527).

\section{Análise de dados}

A leitura dos relatórios empresariais e da informação disponibilizada nas páginas de uma seleção de sociedades de advocacia ${ }^{9}$ em conjunto com nove entre-

\footnotetext{
8 Não existe uma tradução para português, mas pode ser entendido pelo conjunto de atividades de suporte da advocacia, como a pesquisa e a escrita sobre um determinado tema jurídico, distinguindo-se da negociação, do contacto direto com clientes e da atividade em tribunal.

9 Foram selecionadas as sociedades de advocacia Cuatrecasas, Uría Menendez - PC (ambas ibéricas com escritórios em Lisboa e no Porto), PLMJ, Morais Leitão, SRS, VdA. Os principais critérios
} 
vistas a advogadas permite traçar um quadro sobre a liderança no feminino, a igualdade de género e as interseções entre feminismo(s) e neoliberalismo em sociedades de advocacia de grande dimensão em Portugal.

Das quatro sociedades portuguesas, duas não fazem qualquer referência às questões de género (PLMJ 2015; SRS 2018); uma - VdA (2019) - destaca a presença de advogadas nos rankings internacionais de liderança no feminino (IRFL1000 2020) e a sua academia de formação com o programa para mulheres executivas Women on Boards; e uma - Morais Leitão - distingue-se pela certificação como empresa familiarmente responsável ${ }^{10}$, um tipo de validação externa que corresponde à elaboração de um plano de conciliação. A informação disponibilizada refere «a igualdade de oportunidades e a liderança e estilos de direção» ${ }^{11}$ mas não adianta como se concretiza.

As duas sociedades ibéricas - Cuatrecasas (2012, 2018) e Uría (2018) - apresentam planos de igualdade com um conjunto de medidas: i) utilização da variável sexo nos processos de recrutamento e promoção; ii) inquéritos de avaliação às condições e satisfação laboral; iii) flexibilidade no horário e no local de trabalho; iv) programas de talento e liderança dirigidas a advogadas nas fases intermédias de carreira que combinam ações de formação internas e externas, com recurso a coaching e mentoring. Os planos destacam ainda a importância da criação de redes e de contactos, apostando no capital social das suas advogadas, como os almoços de negócios no feminino. Reconhecem que o despedimento na categoria profissional de advogado/a atinge de forma diferenciada homens e mulheres, com um predomínio feminino, entre os 30-49 anos (Uría 2018), e que os planos de igualdade têm tido como resultado um crescimento tímido do número de mulheres em cargos de direção (Cuatrecasas 2018).

Os discursos são caracterizados por ideias progressistas em linha com o feminismo neoliberal e mainstream, sublinhando a importância da inclusão de mulheres através do mérito e da capacitação individual.

A análise das entrevistas permite triangular a informação e, em simultâneo, apresentar as representações das advogadas, aflorando estratégias de compreensão das dinâmicas sociais.

de seleção foram: a dimensão (mais de 100 advogadas/os); a atividade internacional; o prestígio entre pares; a facilidade de acesso aos documentos. A certificação é da responsabilidade de uma organização espanhola, a Fundação Más. Mais informação disponível em: https: / / www.masfamilia.org (último acesso a 29 de junho de 2020). Informação disponível em https:/ / www.mlgts.pt/pt/sobre-nos/ responsabilidade-social (último acesso a 29 de junho de 2020). 


\subsection{Ser mulher: estereótipos, competição e superação individual}

Um dos traços que se desenham na análise dos discursos no feminino é a competição entre mulheres na mesma posição. A competição no feminino surge associada a um conjunto de estereótipos sobre o papel da mulher na sociedade como o ser mais submissa, mais cuidadora, mas também mais arranjada, mais preocupada com o aspeto físico e com a opinião dos outros.

Ela tinha um perfil que caía mais nas boas graças dos advogados, era mais submissa, é mais aquela menina capaz de entrar aqui às oito da manhã e sair à meia-noite todos os dias e não pia. Eu defino mais a minha posição, eu gosto de rir, eu estou sempre a falar, eu sou mais reivindicativa. (Estagiária, 26 anos)

Esta aparente divisão em que as mulheres escolhem as outras mulheres como rivais no interior da organização pode ser interpretado como um sinal de desigualdade de género e sobretudo de processos de genderização das profissões (Pierce 1996) e de divisão social do trabalho (Larson 1977). Espera-se coisas diferentes de homens e mulheres e ambos tendem a reproduzir essas expetativas. O quebrar dessas expetativas para as mulheres, que têm um espaço de atuação mais limitado, implica posicionar-se nos pontos extremos, exacerbando características tidas como femininas de cuidar, de multitasking ou de aceitação das regras e ordens expressas pelas hierarquias, procurando não se destacar.

Acho que uma mulher está a trabalhar e a gerir a casa ao mesmo tempo e a atender telefonemas dos filhos e a marcar consultas no médico. Isso também tem que ver com as características das mulheres, somos mais multitasking. Mas é um facto, não vejo os homens a fazerem isso. (Associada, 27 anos)

Ou sublinhando características consideradas masculinas como a liderança e a negociação. Mas se o ser feminino é socialmente aceite no interior da organização, ainda que criticado por algumas mulheres, o mesmo não se passa com as posturas associadas ao masculino, como a ambição e as longas jornadas de trabalho que podem ser expressas como não condicentes com a imagem do que é ser feminino.

Claro que é entendido como uma certa estranheza, sobretudo para as mulheres. Quando é um homem ninguém diz ele é doido, é completamente doido, fica aqui estas horas todas. Quando é uma mulher há esse cunho pejorativo, é completamente passada, fica aqui estas horas todas a trabalhar. Um homem já é uma pessoa dedicada, já é ali um líder, digamos assim. Isso há, pode não ser tão ostensivo, pode não ser dito tão abertamente, mas em conversas em small talk sim. (Estagiária do 3. ${ }^{\circ}$ ano, 26 anos) 
Uma das advogadas conta as dificuldades em afirmar-se como profissional numa fase intermédia da carreira, associada à angariação de clientes. Nesta fase, os homens somam vantagens: 1) a socialização profissional para a liderança, 2) o exemplo dos sócios maioritariamente homens, e 3) uma maioria de clientes homens. Assim, espera-se resultados semelhantes para homens e mulheres quando as condições de partida são desiguais.

Não diria vedados, mas de mais difícil acesso. Eu acho que se tivesse esta conversa com um homem, ele ia achar que não. Na minha experiência pessoal é mais complicado, espera-se o mesmo, mas é mais complicado. Temos que arranjar outras alternativas. (Associada principal, 32 anos)

As advogadas também apontam a dificuldade em ser reconhecidas como líderes, algo que entendem ser considerado um atributo nos advogados.

A mulher sócia é uma mulher que trabalha (...) os homens geralmente fazem mais sala e elas estão mais focadas no trabalho, porque também lhes é imposto, porque lá está, o homem é o líder e a sócia é a mulher trabalhadora. As qualidades de líder podem-lhe ser reconhecidas mas não são tidas como um dado adquirido como num homem. (Estagiária do 3. ${ }^{\circ}$ ano, 26 anos)

A ideia de superação individual propagada nas revistas especializadas, na publicidade e nos rostos do pós-feminismo (Medina-Vicent 2019, McRobbie 2009) estão muito presentes nos discursos das jovens advogadas, onde se destaca a ideia de eficiência associada à perfeição que, ao não ser alcançada, é entendida como culpa.

Acho que se uma pessoa for supereficiente e se sentar e não se levantar até à hora de almoço e se sentar depois de almoço sem se levantar acho que é possível. Há uma parte que a culpa é minha, sei que podia ser mais eficiente. (Associada, 27 anos)

A planificação da carreira profissional tem em conta a ideia de sacrifício pessoal, a superação individual de que falam as revistas especializadas de gestão, mas também os modelos de advocacia no feminino.

Sim, de rastos, cansadas, com o filho a acordar de três em três horas, mas é possível. Uma das advogadas com que trabalhei o ano passado num processo gigante, ela tinha sido mãe há oito meses, o filho dela não dormia e ela esteve aqui connosco e às vezes eu estava aqui com o A. e ela estava em casa a mandar emails como nós, mas em casa, a trabalhar de casa. (Associada, 30 anos)

A maternidade é idealizada como um momento de superação, de capacitação individual, a prova de força que alia as competências profissionais, «não vai deixar de ser tão boa advogada» com o ritmo de trabalho e o desejo de ser mãe. 
Uma das minhas melhores amigas está grávida e é uma das melhores advogadas de contencioso. Ela teve a trabalhar até ir de férias e deve ter muito mais horas do que eu porque trabalha que se farta, portanto vai cá ficar até ao último dia de ter a criança de certeza e não vai deixar de ser tão boa advogada por causa disso. (Associada, 30 anos)

\subsection{Flexiplan, género e conciliação entre vida familiar e profissional}

O debate em torno do tema da conciliação entre vida familiar e profissional tem levado as sociedades de advocacia a desenvolver estratégias que garantam a continuidade das mulheres no exercício da profissão, seja através de planos de carreira mais flexíveis ou de programas de promoção de talento feminino. Em algumas sociedades, o problema apresenta-se como mais premente.

Eles agora estão a tentar arranjar carreiras alternativas, sobretudo para as mulheres, por exemplo quando têm filhos porque o número de mulheres com filhos é baixíssimo, o número de mulheres é baixo, o número de mulheres com filhos não existe, é baixo, não é assim tão baixo, mulheres com filhos é que não há. (Associada júnior, 26 anos)

O denominado flexiplan permite que o/a advogado/a se mantenha na sociedade com uma redução nos objetivos o que implica uma remuneração mais baixa e uma progressão na carreira mais lenta. Nas palavras de M., uma advogada com dez anos de experiência, este tipo de planos é aceite por mulheres que pretendem conciliar a vida profissional com a maternidade, mas não por homens.

Enquanto instituição, eles tentam fomentar isso e até têm os planos alternativos para quem quer ser mãe ou pai, mas isto nunca foi usado por homens, o chamado flexiplan, que é, reduzem-te o salário, e reduzem-te o objetivo de horas faturáveis, que tu possas ter uma vida para sair mais cedo... se isso funciona, pode funcionar, efetivamente sais mais cedo, mas não vais participar das operações grandes que exigem pela sua própria natureza ficares lá à noite e ao fim de semana, isso prejudica-te na tua carreira. (Associada principal, 32 anos)

Este tipo de programa tem como resultado óbvio passarmos a encontrar dois tipos de carreira profissional: a primeira, mais esperada, de progressão constante (o career track) até ao topo e uma segunda que irá ser pautada por momentos de estagnação ou até mesmo de retrocesso (o mummy track) (Gronlund e Oun 2018). Esta dualidade pode ser bem incorporada na gestão e organização da sociedade, mas pode causar tensões entre as advogadas e os advogados de um mesmo departamento ou equipa, já que por vezes as relações hierárquicas irão inverter-se. Quem sai da linha de progressão pode rapidamente passar a ser chefiado/a por 
alguém que foi seu estagiário ou estagiária, tendo em consideração que a cada três anos existe uma nova possibilidade de progressão.

Obviamente que, se estive um ano em flexiplan, a minha avaliação vai ser pior, porque eu fiz X horas, não tenho transações, não tenho grandes clientes a ligar, não tenho promoção, mas isso é tido em conta na avaliação e não me prejudica. Os outros estão-me a passar à frente e quando for a minha altura de me querer candidatar, não tenho não só aqueles que já estavam à minha frente como tenho todos os que estavam atrás de mim que já lá estão. (Associada principal, 32 anos)

Do ponto de vista da gestão da sociedade, foram encontradas duas soluções: a advocacia de suporte ${ }^{12}$ - em que a advogada ou advogado assume uma função de apoio a uma equipa integrada/o num departamento - e a gestão de conhecimento, um departamento autónomo criado com o intuito de apoiar todas as áreas de prática.

É um trabalho meticuloso, de pesquisa e esses advogados são mulheres, geralmente. São mulheres que têm preocupação em ser mães, então conseguem ir para aquela área em que dão apoio, não digo administrativo, mas de pesquisa ao advogado que está a trabalhar, mas que não estão ali tão ativamente. (Estagiária de 3..$^{\circ}$ ano, 26 anos)

Neste caso, trata-se de responder à necessidade crescente de acesso à informação e de melhor acesso e utilização do conhecimento produzido na sociedade. Estas duas soluções são procuradas sobretudo por mulheres que pretendem conciliar a vida profissional com a vida pessoal.

Agora até já tenho um terceiro filho, não me apetece voltar à advocacia nestas circunstâncias, e gosto particularmente porque fazendo aquilo que eu sei fazer e que sempre fiz e que corresponde ao curso que eu tirei, consigo fazê-lo com muita tranquilidade, e depois não vou negar, muitas vezes quando estou a publicar na base de dados os documentos de uma transação e a F. tem operações fantásticas em que participa, fico a pensar «bem, gostava imenso de ter trabalhado nisto», mas é como tudo na vida, nós temos que escolher e pronto, neste momento prefiro ter essa saudade, mas se tivesse a trabalhar como advogada, se calhar ia odiar. (Especialista em gestão do conhecimento, 34 anos)

\subsection{As academias de talento feminino}

Os programas de talento feminino foram apenas encontrados em duas das seis sociedades de advocacia e são dedicados a mulheres numa fase intermédia de

12 Não dirige operações, não participa nas decisões nem na criação de soluções para um problema. 
carreira. A sua criação é descrita como um misto de sensações positivas e negativas. Positivas no sentido em que as organizações assumem o problema da desigualdade de género, que combina estagnação e/ou abandono, a «sangria de mulheres», e negativas porque são entendidas como insuficientes e, acrescento, decididas numa perspetiva de cima para baixo, como resposta à pressão exterior, mas sem participação das envolvidas.

Eu acho que o problema é que eles começaram a ver que o escritório fazia uma sangria de mulheres e, portanto, agora têm um comité de talentos, retenção de talento feminino, porque os masculinos eles já retêm. (...) ainda não estou incluída nessas coisas, mas fazem imensas conferências e coisas, e vão, as mulheres mais velhas vão a Madrid, têm feito imensos seminários, mas não sei, para mim não é suficiente. (Associada, 26 anos)

No entanto, é reconhecido que as iniciativas produziram efeito, com a promoção de uma advogada a sócia.

Ela é muito boa, mas não era um caso óbvio de vai ser sócio, não era, obviamente que estar ali naquele ano, no ano da sua candidatura, no momento em que surge um programa destes, facilitou-lhe imenso a vida, hoje em dia é uma ótima sócia, ainda bem que subiu, se não tivesse havido o programa, possivelmente não tinha subido, para ela funcionou. (Associada principal, 32 anos)

E mostram-se reticentes quanto aos programas dedicados às mulheres nas sociedades de advocacia, que podem suscitar nos homens a ideia de que as mulheres passarão a ser privilegiadas na promoção de carreira pelo simples facto de serem mulheres (não será isto que sempre aconteceu aos homens?).

Estamos aqui todas a queimar sutiãs, também não queremos que isto seja um programa que ponha os homens a olhar para nós. Elas agora, por serem mulheres, estão numa situação mais vantajosa do que nós, porque agora temos que as pôr lá em cima. (Associada Principal, 32 anos).

Esta desconfiança ou receio face à aceitação de um programa que pretende diminuir as assimetrias de género na organização é mais um sintoma da dificuldade e da falta de espaço social que as advogadas têm para discutir os motivos da discriminação de género e fazerem ouvir a sua voz. A expressão «olhar para nós» pode ser interpretada como uma referência à invisibilidade feminina nas sociedades em que, apesar de estarem de forma crescente em maior número, se encontram em número desproporcional nos lugares de topo e de decisão, sendo muitas vezes responsáveis pelo trabalho não visível. 


\section{Conclusões}

As sociedades de advocacia ocupam um espaço central no desenvolvimento do capitalismo à escala global e são perpassadas por discursos de agentes nacionais e internacionais, onde se incluem o feminismo neoliberal e o feminismo transnacional de negócios.

O contexto português revelou dissonâncias com as dinâmicas internacionais. As sociedades de advocacia mostram-se conservadoras, refugiando-se na ideia da promoção pelo mérito sem qualquer referência às desigualdades de género e assumindo a liderança no feminino como algo que podem ensinar para fora através de academias de formação. As sociedades ibéricas são aquelas que promovem planos de igualdade e reconhecem as dificuldades na permanência e promoção de mulheres na profissão. No entanto, os resultados são tímidos e os planos elaborados de cima para baixo, sem a participação direta das advogadas na sua formulação.

Os discursos das advogadas revelam as tensões entre as suas capacidades de agência e a conformidade com os papéis de género e a cultura organizacional dos escritórios. Reproduzem em parte os modelos essencialistas - superação, sacrifício, multitasking - reconhecem as desigualdades de género e desconfiam da capacidade dos programas de promoção e de flexibilidade laboral. O predomínio da competição individual dificulta formas de organização e de debate coletivos.

As academias de talento feminino estão na encruzilhada entre a reprodução e a emancipação das normas sociais e são nesse sentido um bom exemplo para explorar as contradições e os desafios que os movimentos feministas enfrentam. Se, por um lado, publicitam as questões de género e promovem a formação de advogadas, por outro, não questionam os processos de genderização que limitam a capacidade de ação das advogadas e as amarram a papéis de género construídos a partir de estereótipos de submissão e sacrifício.

As diferenças encontradas entre escritórios portugueses e ibéricos suscitam novas questões e a possibilidade de novas pesquisas que aprofundem o papel dos planos de igualdade e o seu potencial emancipatório.

\section{Referências bibliográficas}

Acker, Joan. 1990. «Hierarchies, Jobs, Bodies: A Theory of Gendered Organizations.» Gender and Society 4 (2): 139-158. DOI: https: / / doi.org/10.1177/089124390004002002.

Banet-Weiser, Sarah. 2018. Empowered: Popular Feminism and Popular Misogyny. Durham, NC: Duke University Press. DOI: https:/ / doi.org/10.1515/9781478002772

Banet-Weiser, Sarah, Rosalind Gill, e Catherine Rottenberg. 2019. «Postfeminism, popular feminism and neoliberal feminism? Sarah Banet-Weiser, Rosalind Gill and Catherine Rottenberg in conversation.» Feminist Theory 21 (1): 1-39. DOI: https: / / doi.org/10.11 $77 / 1464700119842555$

Boltanski, Luc, e Ève Chiapello. 1999. Le Nouvel Esprit du Capitalisme. Paris: Gallimard. 
Bolton, Sharon, e Daniel Muzio. 2007. «Can't live with'em; can't live without'em: gendered segmentation in the legal profession.» Sociology, 41 (1): 47-64.

Cuatrecasas. 2012. Gender Equality Plan. DOI: https: / / doi.org/10.1177/ 0038038507072283.

Cuatrecasas. 2018. Memoria Corporativa. Disponível em: https://indd.adobe.com/view/ c6e07a28-2791-4449-b367-0b07ba835637

Dezalay, Yves, e David Sugarman. 1995. Professional Competition and Professional Power. London: Routledge.

Elias, Juanita. 2013. «Davos woman to the rescue of global capitalism: Postfeminist politics and competitiveness promotion at the World Economic Forum.» International Political Sociology 7 (2). DOI: https: / / doi.org/10.1111/ips.12015

Faulconbridge, James, e Daniel Muzio, 2008. «Organizational Professionalism in Globalizing Law Firms.»Work, Employment and Society 22: 7-25. DOI: https:// doi.org/10.1177/ 0950017007087413

Faulconbridge, James, e Daniel Muzio, 2012. «Professions in a globalizing world: Towards a transnational sociology of the professions.» International Sociology 27 (1): 136-152. DOI: https: / / doi.org/10.1177/0268580911423059

Fraser, Nancy. 2016. «Progressive Neoliberalism versus Reactionary Populism: A Choice that Feminists Should Refuse.» Nordic Journal of Feminist and Gender Research 24(4), 281-284. DOI: https: / / doi.org/10.1080/08038740.2016.1278263

Galanter, Marc, e William Henderson, 2008. «The elastic tournament: a second transformation of the big law firm.» Stanford Law Review 60: 1867-1929.

Goldman Sachs. 2009. The Power of the Purse: Gender Equality and Middle-Class Spending. Global Markets Institute. [Disponível em https:/ / www.goldmansachs.com/insights / investing-in-women/bios-pdfs / power-of-purse.pdf]

Gronlund, Anne, e Ida Oun. 2018. «Beyond the Mummy Track? Part-time Rights, Gender, and Career-Family Dilemmas.» Nordic journal of working life studies 8 (3): 177-199. DOI: https:/ / doi.org/10.18291/njwls.v8i3.109546

Hanlon, Gerard. 1998. «Professionalism as enterprise: service class politics and the redefinition of professionalism.» Sociology, 32 (1):43-63.DOI:https: / / doi.org / 10.1177 / 00380385803 2001004

IFLR1000. 2020. Women Leaders 2020 - Europe, Middle East and Africa. Disponível em: https: / / www.iflr1000.com / NewsAndAnalysis / IFLR1000-Women-Leaders-2020-EuropeMiddle-East-and-Africa/Index/10843

Kohll, Alan. 2019. «Why Your Company Should Offer Fertility Benefits.» Forbes 10 de abril. Disponível em: https:/ / www.forbes.com/sites/alankohll/2019/04/10/why-yourcompany-should-offer-fertility-benefits / \#4d8846117699

Larson, Magali. 1977. The Rise of Professionalism: A Sociological Analysis. Berkeley, CA: University of California Press.

McDowell, Linda. 2010. «Capital Culture Revisited: Sex, Testosterone and the City.»International Journal of Urban and Regional Research 34 (3): 652-658. DOI: https://doi.org/ 10.1111/j.1468-2427.2010.00972.x.

McRobbie, Angela. 2009. The Aftermath of Feminism: Gender, Culture and Social Change. London: SAGE.

Medina-Vicent, Maria. 2019. «Feminismo vs Neoliberalismo: una reflexión crítica sobre el liderazgo empresarial de las mujeres.» Athenea Digital 19 (2), e2441. DOI: https: / doi. org/10.5565/rev/athenea.2441.

Pierce, Jennifer. 1996. Gender trials: Emotional lives in contemporary law firms. Oakland, CA: Universtiy of California Press. DOI: https: / / doi.org/10.1525/ california/97805202010 71.001.0001. 
PLMJ. 2015. Relatório de Responsabilidade Social Corporativa 2013-2014. Disponível em: https: / / www.plmj.com / xms / files / v1_antigos_anteriores_a_abr2019/ Artigos_e_ Publicacoes/2014/Relatorio_Responsabilidade_Social_PLMJ_FINAL.pdf

Roberts, Adrienne. 2012. «Financial Crisis, Financial Firms... And Financial Feminism? The rise of 'Transnational Business Feminism' and the necessity of Marxist-Feminist.» IPE, Socialist Studies 8 (2): 85-108. DOI: https:/ / doi.org/10.18740/S40W2K.

Rottenberg, Catherine. 2014. «Happiness and the Liberal Imagination: How Superwoman Became Balanced.» Feminist Studies 40 (1): 144-168.

Rottenberg, Catherine. 2017. «Neoliberal Feminism and the Future of Human Capital.» Signs: Journal of Women in Culture and Society 42 (2): 329-348. DOI: https: / / doi.org/ $10.1086 / 688182$.

Santos, Susana. 2017. «Os estágios profissionais em grandes sociedades de advocacia: contributo para o estudo das formas de socialização profissional». I Encontro da Sessão Temática Sociologia do Direito e da Justiça. CES Contexto 19: 341-353.

Santos, Susana. 2018. «Becoming a lawyer in a large law firm: the idea of the unstoppable worker.» Professions and Professionalism 8 (3). DOI: https:/ / doi.org/10.7577/ pp.2285.

SRS. 2018. Relatório de Responsabilidade Social 2017. Disponível em: https:/ / www.srslegal .pt/pt/a-sociedade/ responsabilidade-social/

Uría Menendez, 2018. Relatório de Sustentabilidade. Disponível em: https: / www.uria.com/ dam/jcr:b13d292b-61d0-4352-882f-6c4ea149b0c0/UM-RSC-2018-POR.pdf

VdA. 2019. Relatório de Responsabilidade Social Corporativa. Disponível em: https:/ / www. vda.pt/pt/media/ pro-bono/relatorio-de-responsabilidade-social-corporativa2019/22232/

Walsh, Janet. 2012. «Not Worth the Sacrifice? Women's aspirations and career progression in law firms.» Gender, Work and Organization 19 (5): 508-531.

Wilkins, David, e Mitu Gulati. 1996. "Why Are There So Few Black Lawyers in Corporate Law Firms? An Institutional Analysis.» California Law Review 84: 493-541. DOI: https: / / doi.org/10.15779/Z382B0H

Wittenberg-Cox, Avivah. 2020. «What Do Countries with the Best Coronavirus Responses Have In Common? Women Leaders.» Forbes 13 de abril. Disponível em: https:/ / www.forbes.com/sites/avivahwittenbergcox/2020/04/13/what-do-countries-withthe-best-coronavirus-reponses-have-in-common-women-leaders / \#6ac9e21b3dec.

Susana Santos. Doutorada em Sociologia. Investigadora integrada no Cies.Iscte, Centro de Investigação e Estudos em Sociologia e professora auxiliar convidada na Escola de Sociologia e Política Públicas do ISCTE - Instituto Universitário de Lisboa. Os seus temas de investigação têm-se centrado em torno da formação de elites transnacionais no campo da advocacia e na formação de esferas públicas em diferentes contextos, com particular interesse pela produção discursiva.

Endereço eletrónico: susanacsantos@iscte.pt

Artigo recebido em 30 de junho e aceite para publicação em 7 de outubro de 2020. 


\title{
FAZER O MESMO, SEM SER O MESMO: FEMINILIDADES, NEOLIBERALISMO E ANTIFEMINISMO NO CONTEXTO GODLLYWOOD BRASIL
}

\author{
Monise Martinez* \\ (D) https: / / orcid.org/0000-0002-2324-9752
}

\section{Resumo}

Nas últimas duas décadas, processos políticos e sociais têm culminado, globalmente, numa hipervisibilização dos feminismos pautada numa dinâmica de ações e de reações a estes. A neoliberalização dos feminismos, notável na emergência de «subjetividades femininas» construídas a partir deles ao passo que os descontrói, no âmbito secular e religioso, tem corroborado esta conjuntura. Situando nesta dinâmica o programa disciplinar Godllywood Autoajuda, da Igreja Universal, no Brasil, neste artigo traçarei as relações entre as «feminilidades» propagadas por este visando examinar suas convergências com as neoliberais na sua relação com os feminismos através de uma análise do conteúdo, feminista e crítica dos discursos propagados na edição de 2018.

Palavras-chave: feminilidade; neoliberalismo; pós-feminismo; antifeminismo; Godllywood.

\begin{abstract}
Doing the same without being the same: Femininities, neoliberalism and antifeminism in the Godllywood Brazil context.

In the last two decades, political and social processes have culminated in a hyper-visibility of feminisms guided by global actions and reactions to them. The neoliberalization of feminisms, marked by «female subjectivities» built out of them while deconstructing them in both secular and religious fields, has corroborated this conjuncture. Setting the Brazilian Universal Church's Godllywood Self-help disciplinary program in this context, in this article I will analyze the relations between the «femininities» promoted by it and the neoliberal ones, calling attention to their connections to feminisms. For this purpose, a feminist critical content analysis of the speeches disseminated in the 2018 program edition will be carried out.
\end{abstract}

Keywords: femininity; neoliberalism; postfeminism; anti-feminism; Godllywood.

\section{Resumen}

Haciendo lo mismo, sin ser lo mismo: Godllywood, feminismos y las disputas por visibilidad en el Brasil contemporáneo.

Procesos políticos y sociales han contribuido para una hiper-visibilidad de los feminismos, a nivel global, en las últimas dos décadas. La neoliberalización de los feminismos ha corroborado esta coyuntura, como viene demostrando la emergencia de «subjetividades

Doutoranda em Estudos Feministas no Centro de Estudos Sociais, Univ Coimbra (CES/UC), 3000-104 Coimbra, Portugal.

Endereço postal: Centro de Estudos Sociais, Colégio de São Jerónimo, 3000-104 Coimbra, Portugal. Endereço eletrônico: martinezmonise@gmail.com 
femeninas» que se construyen desde ellos mientras los deshacen en el marco del secular y del religioso. Ubicando en esta dinámica el programa disciplinar Godllywood Autoayuda, de la Iglesia Universal, en Brasil, en este artigo identificaré las convergencias entre las «feminidades» impulsadas por el programa y las neoliberales en su relación con los feminismos desde un análisis del contenido, feminista y crítico de los discursos propagados en la edición 2018 del programa.

Palabras-clave: feminidad; neoliberalismo; postfeminismo; antifeminismo; Godllywood.

\section{Introdução}

Ao longo das últimas décadas, estudos sobre as relações entre os feminismos e o neoliberalismo têm destacado diferentes estratégias por meio das quais, seja enquanto um projeto político, uma doutrina econômica ou uma racionalidade, o neoliberalismo tem cooptado os feminismos (Prügl 2015). Categorizada, consoante o enfoque adotado, como feminismo de mercado e feminismo neoliberal, a expressão feminista derivada deste processo de neoliberalização tem sido examinada, no campo da comunicação e dos media, sob as lentes do pós-feminismo - termo sensivelmente usado para referir um fenômeno observado primeiramente na cultura mediática e pop no Norte global, a partir dos anos 1990, resultante das intersecções entre os media, a cultura de consumo, a política neoliberal e os feminismos (Genz e Brabon 2009).

Dentre as tendências comuns ao fenômeno, a emergência de subjetividades femininas tem sido um importante parâmetro para análise. Ao longo dos anos 2000, estudos sobre o tema evidenciaram uma dinâmica ambígua entre tais subjetividades e os feminismos na medida em que estas pareciam construir-se a partir deles ao passo que os descontruíam (McRobbie 2004; McRobbie e Ross 2011), bem como sistematizaram aspectos destas subjetividades atentando-se especialmente a gramática neoliberal que as atravessava, pautada nos credos da liberdade de escolha, transformação, autonomia feminina e disciplinarização dos corpos (Gill 2007; 2008; Gill e Scharff 2011). No Sul global, o conceito «pós-feminismo» tem sido usado em alguns estudos para destacar a existência de um regime de colonialidade de gênero no qual, na medida que tais subjetividades são difundidas como hegemônicas, adentram igualmente à vida cultural em realidades neoliberalizadas outras, como no caso da América Latina (Giraldo 2016).

Mudanças substanciais nas relações entre tais subjetividades e os feminismos têm sido notadas, contudo, na esteira de fatores múltiplos que têm corroborado, especialmente nesta última década, um momento de hipervisibilidade dos feminismos (Banet-Weiser, Gill, and Rottenberg 2020). Dentre os principais, é certo que os avanços nas agendas de gênero desde a IV Conferência Mundial da Mulher, em Pequim, em 1995, bem como o ciberfeminismo têm sido importantes para este efeito (Matos 2017). Junto deles, outros fatores relacionados têm sido notados, 
nomeadamente: o aumento de iniciativas neoliberalizadas que se reivindicam feministas alinhando-se, contraditoriamente, às forças sociais e culturais promotoras de iniquidades estruturais de gênero (Banet-Weiser, Gill e Rottenberg 2020); a proeminência de subjetividades femininas individualizadas, que invisibilizam e esvaziam o sentido político dos feminismos face as expressões engajadas (BanetWeiser, Gill e Rottenberg 2020); expansão e fortalecimento de reações antigênero por meio da direita conservadora a nível global (Corredor 2019); e a intensificação de reações misóginas na paisagem midiática ${ }^{1}$ (Banet-Weiser 2018).

Neste contexto, alguns estudos têm identificado a emergência de perfis de feminilidade delineados em conformidade com subjetividades neoliberais, em oposição aos feminismos, verificados em iniciativas corporativas e mediáticas associadas a grupos religiosos cristãos. Nos Estados Unidos, por exemplo, uma análise das narrativas de sucesso publicadas on-line por trabalhadoras de uma empresa ligada ao American Prosperity Gospel (APG) - movimento dissidente do Pentecostalismo, adepto da Teologia da Prosperidade (TP) e gerador de uma indústria de mídia e publicação (Bowler 2013) - destacou a existência de um perfil de «subjetividade pós-feminista evangélica» assente no reforço dos papéis tradicionais de gênero (Sullivan e Delaney 2016). No entanto, estudos mais detalhados sobre as convergências de fatores que sustentam estas subjetividades ainda são escassos, de maneira geral.

Visando contribuir para o desenvolvimento desta literatura, o presente artigo busca promover uma reflexão sobre o tema situando-o no contexto do Sul global, por meio de uma análise do ideário de feminilidade promovido pela Igreja Universal do Reino de Deus (IURD) - grupo neopentecostal, de afinidade teológica com o APG. No coração desta proposta, está a constatada proeminência que as questões relacionadas ao "gênero» e aos «feminismos» têm tido na esfera pública brasileira; o uso meta-político que se tem feito destas categorias nas disputas de narrativa na "paisagem midiática», marcada por uma forte presença de ações feministas e reações misóginas; e a hipótese de que, em tempos «pós-feministas», a IURD tem sido uma força importante na construção política de uma ideologia de gênero ${ }^{2}$ aliada ao conservadorismo de direita por meio da propagação de um ideário de feminilidade conhecidamente arraigado em papéis tradicionais de gênero, disseminado, no entanto, numa relação de oposição aos feminismos através de uma estratégica cooptação e esvaziamento político destes, além de estreitas relações com expressões neoliberalizadas.

Para o cumprimento do objetivo antes explicitado, este artigo será dividido em sete partes: a primeira consistirá numa leitura contextual das dinâmicas de

Cf. Banet-Weiser (2018), um contexto econômico e tecnológico de visibilidade em que expressões do feminismo e a misoginia disputam pela hegemonia de significados.

2

Neste contexto, «ideologia de gênero» é usado para referir crenças estruturadas e ideias sobre construções sociais associadas aos corpos sexuados. 
polarização e ambiguidades em torno dos feminismos na paisagem política e midiática brasileira; a segunda incide sobre a emergência de um grupo seleto de mulheres da IURD nas mídias da Igreja na sua relação com o surgimento de um projeto disciplinar voltado para mulheres chamado Godllywood, em 2010, atentando-se à modalidade on-line «Autoajuda»; a terceira é dedicada à apresentação do corpus e da metodologia de trabalho na identificação do ideário de feminilidade proposto pela Igreja, bem como das estratégias retóricas usadas na sua construção; a quarta, quinta e sexta partes apresentam a análise qualitativa do material selecionado; a sétima, enfim, discute os contributos deste trabalho.

\section{Da política institucional à paisagem midiática: polarização, feminismos e conservadorismos}

O neoliberalismo e os posicionamentos contrários a um projeto feminista de sociedade têm sido apontados como denominadores comuns no espectro da direita conservadora a nível global (Norocel 2018). Dentre as estratégias adotadas na construção das narrativas neste meio, está a disseminação da «ideologia de gênero» - um projeto político articulado pela Santa Sé, especialmente após Pequim, com vistas a conter os supostos «perigos» da perspectiva construcionista de gênero defendida por delegadas feministas na ocasião, bem como os avanços e visibilidade paulatina de suas bandeiras e das LGBTQ+ desde então (Machado 2018; Corrêa e Kalil 2020). Convergindo com os interesses econômicos comuns no conservadorismo de direita, o qual, ao defender a «família tradicional» baseando-se numa hierarquia complementar sustentada teológica e biologicamente entre o masculino e o feminino, reforça a ordem patriarcal (Norocel 2018), a narrativa do combate à «ideologia de gênero» tem sido uma das principais linhas de força adotadas por representantes populistas do espectro, como o caso Bolsonaro no Brasil (Payne e Santos 2020).

$\mathrm{Na}$ arena da política institucional do país, parte substancial dos embates polarizados que tomaram as redes e as ruas em 2018 tiveram início em 2003, no primeiro mandato de Lula, quando as primeiras polêmicas relacionadas à adoção da perspectiva construcionista sobre «gênero» nas políticas públicas e os avanços das agendas em torno dos direitos reprodutivos e da sexualidade emergiram no Congresso Nacional (Machado 2018). Contudo, é certo que a retórica da «ideologia de gênero» adquiriu maior corpulência no país a partir de 2008, na esteira de uma emblemática visita de Ratzinger, da assinatura de um acordo entre a Santa Sé e o Estado brasileiro em torno das ações da Igreja Católica no país e, enfim, da consolidação de um campo de obras e publicações antigênero (Corrêa e Kalil 2020). Neste processo de disseminação, a retórica ganhou especial impulso no Congresso em 2010, quando católicos e evangélicos uniram esforços dentro e fora da política institucional em prol da retirada dos termos «gênero» e «orientação sexual» do 
Plano Nacional de Educação (PNE) inaugurando uma nova fase de reações de parlamentares antigênero.

Paralelamente a este quadro legislativo, a emergência de uma nova estrutura nos media sociais contribuiria, na paisagem midiática brasileira, para uma intensificação das batalhas por hegemonia de discursos a partir de 2013, quando a polarização entre forças feministas, LGBTQ+ antirracista e, no contraponto, conservadora tornou-se mais evidente on-line. Naquele ano, manifestações com reivindicações plurais e consoante diferentes contextos tomaram as ruas de diversas partes do país, adentrando no espectro dos emblemáticos atos que tiveram lugar a partir de junho, quando tiveram início ações encabeçadas pelo Movimento Passe Livre (MPL) contra o aumento das tarifas do transporte público em São Paulo (Pinheiro-Machado 2019). Apoiadas pela grande mídia após um violento episódio de repressão policial no ato do dia 13 de junho, uma nova face das manifestações emergiu com agendas difusas e apropriadas pela direita, pautadas em narrativas de vilanização de movimentos como os feministas, LGBTQ+ e antirracistas, bem como do PT, das esquerdas, do comunismo e da ONU (Pinheiro-Machado 2019; Corrêa e Kalil 2020).

O momento de convulsão política impulsionado pelas «Jornadas de Junho» foi propiciado, contudo, por fatores precedentes de ordem diversa que culminaram naquele momento. No que respeita ao uso das redes, por exemplo, é importante destacar que blogues, perfis e sites feministas estavam em ascensão desde meados dos anos 2000, e foram impulsores cruciais para o ativismo e a visibilidade dada aos feminismos no contexto brasileiro ao operar como ferramentas na expansão do movimento (Ferreira 2015; Matos 2017). Junto deste fortalecimento, contudo, expressões neoliberalizadas também foram ganhando forças, e organizações católicas e evangélicas faziam uso das redes para disseminar a narrativa da «ideologia de gênero», a qual é antifeminista per se (Corrêa e Kalil 2020). Com o estabelecimento de novas tendências on-line a partir de 2013, os embates entre estas expressões se acirraram. Assim, ao mesmo tempo que manifestações significativas e campanhas on-line culminavam na «Primavera das Mulheres», em 2015 (Reis 2017), e os feminismos apareciam nos anúncios televisivos, debates nas redes sociais e no mercado editorial, reações antifeministas eram promovidas por celebridades e movimentos de direita on-line, como o Movimento Brasil Livre (MBL) (Ferreira 2019); vídeos disseminados por pastores evangélicos sobre a «ideologia de gênero» eram amplamente difundidos; e materiais sobre o tema produzidos por grupos de cristãos conservadores eram distribuídos em todo o país (Machado 2018).

Neste cenário de polarização, mulheres desempenharam - e têm desempenhado - papéis cruciais no fortalecimento de ações antifeministas. Nos bastidores do Congresso Nacional, por exemplo, a participação de católicas e pentecostais serviu para sublinhar a existência de ativistas que, sem se identificarem como feministas, diziam-se comprometidas com os direitos das mulheres e contrárias à 
«ideologia de gênero» (Machado 2018). Nas redes, iniciativas de grupos de direita davam protagonismo a mulheres antifeministas, como Sara Giromini, que organizou o I Congresso Antifeminista Brasileiro em 2018 (Ferreira e Silva 2019). Nos media religiosos, pastoras e esposas de pastores evangélicos frente à audiência feminina com vistas a fomentar «modelos de feminilidade» tradicionais cumpriam igualmente um importante papel neste cenário usando suas redes pessoais ou canais institucionais das Igrejas (Machado 2018), como o caso de Cristiane Cardoso, da IURD, que tem apresentado uma performance «transreligiosa» (Campos e Souza 2017), ancorada numa gramática «pós-feminista», combatendo agendas feministas especialmente por meio de iniciativas ligadas ao Godllywood (Martinez 2018).

\section{Resposta «Universal»: mídia, mulheres e a criação do Godllywood}

A IURD foi fundada em 1977, por Edir Macedo, no Rio de Janeiro. É uma Igreja neopentecostal, adepta da Teologia da Prosperidade (TP) originariamente difundida pelo American Prosperity Gospel (APG) e, por isso, fundamentada na crença de que cumprindo um estrito percurso de fé, fiéis logram alcançar riqueza, saúde e vitória. Desde a sua fundação, caracterizada pelo uso massivo dos meios de comunicação, do rádio às novas mídias, a Igreja foi considerada uma peça-chave para mudanças significativas no campo religioso brasileiro na sua relação com o campo político (Martino 2017, 41-46). Da participação na fundação da Frente Parlamentar Evangélica, em 1986, à compra da Rede Record, em 1989, à criação do Partido Republicano Brasileiro (PRB), em 2005, e à eleição de 106 prefeitos pela sigla em 2016, a atuação política estruturada da IURD tem sido substancialmente permeada pelo uso que faz de suas mídias religiosas (Suruagy apud Dip 2018).

Em seu contexto de atuação midiática, o enfoque em temas relacionados às mulheres, bem como a presença destas nas atividades da Igreja nas mídias eletrônicas e impressas teve início no fim dos anos 1990 (Machado 1999, 184). Seguindo as tendências de incorporação de pautas dirigidas à audiência feminina e de contratação de mulheres nas mídias «seculares», esposas de bispos e pastores entraram em cena para abordar temas relacionados à saúde feminina na programação radiofônica, e também na televisiva, onde atendiam e aconselhavam pessoas, especialmente mulheres, legitimando as opiniões antes emitidas por seus maridos (Machado 1999, 171-175). Com a popularização das mídias digitais no início dos anos 2000, a participação das mulheres nas mídias do Grupo Universal foi intensificada, marcada por sua atuação em blogues e redes sociais. Entre as que ganharam maior visibilidade neste contexto, está Cristiane Cardoso, filha primogênita de Edir Macedo, desde 2007 autora de best-sellers e principal representante do Godllywood. 
O projeto Godllywood foi concebido por Cardoso e Evelyn Higginbotham, em 2009, em Houston, nos Estados Unidos, tendo como principal objetivo tornar jovens fiéis da Igreja «melhores para Deus» à base de um programa disciplinar articulado em torno de reuniões de grupo e do cumprimento de tarefas prescritas por mentoras nomeadas Big Sisters. ${ }^{3}$ Implementado no Brasil no ano de 2010, o projeto foi apresentado com vistas a combater «valores errados» promovidos por Hollywood através do resgate de uma suposta «essência feminina» prescrita por Deus $^{4}$ num momento em que os discursos antigênero ganhavam força no país, plataformas feministas on-line despontavam e o Censo revelava que as mulheres eram a maioria entre a população evangélica.

Inicialmente operacionalizado em templos de capitais brasileiras e restrito a grupos seletos de frequentadoras da Igreja, o projeto atendia um público feminino em diferentes faixas etárias, era facilitado por esposas de bispos e pastores, representado em seu máximo por Cardoso e dinamizado através do cumprimento de «desafios»: tarefas diárias que, sistematizadas num calendário semanal, culminavam na produção de pequenas narrativas de êxito a serem partilhadas pelas integrantes adolescentes e adultas na página do projeto no Facebook (Teixeira 2014, 237-238). Em 2011, quando o ativismo feminista on-line ganhava forças, culminando na organização de atos como a primeira Marcha das Vadias no Brasil, a primeira modalidade on-line do programa, nomeada Desafio Godllywood, foi implementada atendendo a demandas de mulheres da IURD em cidades e países outros (Teixeira 2014, 248-249). Em dezembro de 2015, ano da já referida «Primavera das Mulheres», uma versão estendida a toda e qualquer mulher interessada em participar da dinâmica foi lançada: o Godllywood Autoajuda.

Como na versão do programa in loco, tal modalidade foi construída em torno de um percurso de aprimoramento pessoal focado na performance da «mulher virtuosa». Perfil apresentado em minúcia por Cristiane Cardoso no best-seller Mulher V: Moderna à moda antiga (2011), publicado um ano após a implementação do Godllywood no Brasil, a «Mulher V» consiste numa versão repaginada do modelo de feminilidade introduzido por Macedo em O perfil da mulher de Deus (1992), tendo sido inspirado no livro The Total Woman (1973), de Marabel Morgan (Teixeira 2012). Buscando tecer um diálogo mais próximo com o público feminino, o best-seller de Cardoso reivindica o lugar da experiência de quem o escreve: uma mulher que logrou ter sucesso no casamento, na família, no trabalho e na vida espiritual, e que partilha seus ensinamentos com as demais apresentando-se como um exemplo. À parte disto, valendo-se de uma linguagem mais próxima do «secular», o best-seller é também construído a partir de narrativas comuns à literatura de

Informações disponíveis em: http://redealeluia.com.br/odllywood-o-resgate-da-essencia-femininal. Acesso em 24 de outubro de 2020.

4 Informações disponíveis em: https://instagram.com/tv/B74QIC8gEPb/?hl=pt. Acesso em 24 de outubro de 2020. 
autoajuda - a qual está arraigada em elementos míticos da cultura popular norte-americana -, introduzindo o ideário da Mulher $V$ numa relação de oposição a modelos de feminilidade que julga «hegemônicos», nocivos às mulheres e relacionados ao que entendem, de modo geral, como feminismo (Martinez 2018).

Tendo o referido modelo de feminilidade como base de sua estrutura basilar, a modalidade Autoajuda foi operacionalizada, entre os anos de 2016 e 2018, usando o blogue oficial do projeto como principal ferramenta. Por meio de posts com tarefas publicadas semanalmente durante um período específico do ano por Cristiane Cardoso, o programa apresentava-se como uma proposta de «transformação» voltada para mulheres estruturando-se a partir de três componentes: uma diretiva, executada por Cardoso, que informava, nos posts, o quê, como e por quê deveria ser feito; uma tutelar, administrada pelas esposas de pastoras nos templos, em reuniões mensais in loco, e/ou pela figura da «amiga como irmã», uma mulher escolhida pela própria participante para acompanhá-la em sua jornada incentivando-a; e a de auto-gestão, administrada pelas participantes. As «tarefas como oferta» organizavam-se em torno de práticas de ação direta e de autorreflexão, sobre temas como a espiritualidade, a feminilidade e os cuidados com o corpo e com a mente, e eram eventualmente partilhadas pelas participantes nos comentários do blogue ou em suas redes sociais, com uso de hashtags, à parte da recomendação de serem registradas num diário. Por meio desta dinâmica, a expectativa era a de que as mulheres incorporassem um perfil determinado de subjetividade feminina e cristã, ancorada nos papéis tradicionais de gênero, mas apresentadas, contudo, a partir de uma estética mais «secularizada» a fim de ampliar a sua visibilidade na paisagem midiática brasileira.

A partir de 2019, a modalidade passou a ser operacionalizada de modo mais centralizado por meio de perfis no Instagram e no Youtube, tendo o Godllywood alcançado o status de «movimento»: uma mudança apresentada na página oficial do programa como necessária para expandir a iniciativa entre mulheres interessadas em «viver segundo os princípios e conceitos» do programa. Apresentado como um movimento «sem ideologia», a iniciativa identifica-se como um «movimento de mulheres diferente do 'feminista'», propondo-se de forma mais ou menos indireta, como uma alternativa a este por meio da propagação do modelo de Mulher $V$, a qual, tendo-se em conta os já referidos contextos de polarização em torno de "gênero» e «feminismo» no Brasil das últimas décadas, tem sido construído numa relação de oposição estratégica aos feminismos. Apresenta, no entanto, estreitas relações com expressões neoliberalizadas enquanto resposta aos avanços e alta visibilidade por eles adquiridos, bem como sua relevância na conjuntura de disputas políticas no Brasil e a nível global. 


\section{Metodologia}

Tendo em vista o objetivo central deste artigo, foram selecionados para a análise vinte posts de autoria de Cardoso no blogue oficial do Godllywood entre fevereiro e março de $2018,{ }^{5}$ no âmbito da edição Autoajuda do referido ano. A escolha deste material deu-se em função de três razões: o fato de constituir a última edição em que blogue fora usado como principal ferramenta para a realização do programa em larga escala; a última antes do Godllywood ser declarado como um «movimento»; e, enfim, num período acirrado de disputas de narrativas em torno das questões de «gênero», como já dito, marcado pelas eleições presidenciais que teriam lugar em outubro daquele ano.

Usando primeiramente como metodologia a análise de conteúdo (Bardin 2011), a unidade de análise determinada durante a fase de codificação do material foi a das recomendações em tom imperativo e/ou de conselho dadas às participantes do programa a cada tarefa. De seguida, após uma segunda leitura dos excertos antes codificados, duas categorias temáticas de análise foram determinadas tendo-se em conta a noção de «sensibilidade pós-feminista» cunhada por Gill (2007) para enfatizar «a natureza contraditória dos discursos pós-feministas e as relações entre os temas feministas e antifeministas dentro deles» (151) e a compreensão do feminismo de acordo com a definição mínima de hooks (1984: 26) enquanto «luta pelo fim da opressão sexista»: $a$. a cooptação do feminismo por meio de aproximações estratégicas da retórica de suas expressões neoliberalizadas; e $b$. subversão do feminismo por meio de sua vilanização e/ou difamação.

Sob estas categorias, três tendências recorrentes foram encontradas nos posts analisados: mente, na qual foram agrupados excertos construídos a partir de imperativos sobre temas como «autoconfiança», «autoestima» e «positividade»; corpo, constituída por excertos sobre os cuidados com a aparência; e comportamento feminino, na qual se encontram as prescrições relacionadas precisamente com a ideia de feminilidade. Para a interpretação de tais excertos, uma análise crítica e feminista do discurso (Lazar 2007) foi realizada com vistas a compreender «como a ideologia de gênero e as relações de poder em torno do gênero são (re)produzidas, negociadas e contestadas nas representações de práticas sociais» (150).

Nos tópicos a seguir, a análise focada nas estruturas argumentativas, escolhas lexicais e padrões de enunciados no corpus será apresentada consoante cada um dos padrões pré-determinados.

Todas as tarefas da edição Autoajuda 2018 estão disponíveis no link: https://universal.org/godlly wood/auto-ajuda/. Acesso em 12 de julho de 2020. 


\section{Feminilidade e mente}

O paradigma de transformação pessoal tornou-se um elemento central na cultura pós-feminista (Gill 2017). Especialmente popularizado na cultura midiática e popular dos anos 1990 e 2000 por meio de propostas disciplinares que propunham-se a resolver dilemas da vida física, afetiva e psicológica de mulheres, as lógicas deste paradigma foram revitalizadas à medida que o processo de neoliberalização dos feminismos avançou, acomodando-se cada vez mais ao credo individualizado no «empoderamento feminino» em torno de mantras relacionados à autoconfiança, à positividade, à autoestima e à resiliência - «novos» elementos de sucesso feminino (Gill 2017).

Nas tarefas propagadas no âmbito do Autoajuda 2018, a gramática «secular» que envolve estes mantras foi adaptada à cosmovisão neopentecostal - a qual entende o sucesso como a prova de que o indivíduo está em dia com a sua fé. Assim, apresentados e incentivados no programa por meio de práticas que têm como maior propósito «agradar a Deus», os mantras da autoconfiança e da autoestima, por exemplo, são tomados como sinais de que as mulheres estão cumprindo com o propósito do programa, como exemplifica o fragmento extraído de uma tarefa centrada na questão da proatividade:

Ficar adiando a sua vida é um sinal de baixa autoestima, insegurança, irresponsabilidade, preguiça, fraqueza, dúvida, confusão, depressão, desorganização e, consequentemente, NÃO SER DE DEUS. Repare o quanto você se sente longe de Deus quando se descuida e deixa o tempo escapar por entre os dedos.

A Tarefa como Oferta 16 é para você fazer o que Deus faz: controle o seu tempo, tenha disciplina, e nunca mais deixe que algo atrase a sua vida - seja preguiça, lentidão ou distração. Em outras palavras: trabalhe duro. (Cardoso 2018, Tarefa 16)

Como demonstra o fragmento, o processo disciplinar de transformação godllywoodiano é atravessado por uma ideia de gestão e controle de demandas mentais com vistas a eficiência, também reforçadas em várias ações por meio das quais as mulheres são incentivadas a se tornarem as melhores no que fazem (ver Tarefas 13 e 14). À semelhança dos discursos pós-feministas sobre as práticas de transformação, no programa estas premissas corroboram a responsabilização das participantes pelo seu bem-estar psicológico, reduzindo problemas como a depressão e insegurança a uma escolha pessoal. Invisibilizando desigualdades estruturais, a solução foca-se no fomento de ações individuais como «orar» e «ser positiva», sendo constantemente reforçada por Cardoso assente na fórmula do sucesso que define, também, as subjetividades feministas neoliberalizadas:

Depois que entramos no mercado de trabalho e adquirimos os direitos iguais aos dos homens, a simplicidade de ser mulher se tornou uma verdadeira complexidade! 
Temos que dar conta de tudo e não deixar nada a desejar, senão dizem que é porque somos mulher. (Cardoso 2018, Tarefa 15)

No entanto, e como demonstra o fragmento, diferente do sujeito que se reivindica como feminista ao "glamorizar» a sobrecarga que recai sobre as mulheres por meio da valorização de iniciativas criativas e empreendedoras para gerir o tema (Rottenberg 2018, 36-39), o programa invoca a mesma estrutura para culpabilizar o feminismo por este feito, como denota a ideia negativa de «complexificação» da vida de mulheres atrelada às menções sobre a entrada destas no mercado de trabalho e aos «direitos iguais», isto é, bandeiras históricas do movimento feminista dos anos 1970 .

\section{Feminilidade e corpo}

O corpo feminino é também um aspecto central da cultura pós-feminista (Gill 2017). Representado como um elemento definidor da feminilidade na cultura popular e mediática das décadas de 1990 e 2000, àquela época o corpo era reivindicado como uma «fonte de poder feminino» estabelecendo uma relação ambígua com os feminismos: ao passo que simbolizava um espaço de ressignificação positiva da ideia de «feminino», tornava-se foco de práticas de monitoramento e disciplina que delineavam novos padrões de atratividade em torno de temas como liberdade sexual, escolha e empoderamento (Gill 2007). No cenário de intensificação da visibilidade e neoliberalização dos feminismos, o corpo se tornou, também, um outdoor do feminismo enquanto mercadoria, servindo, no que respeita o caso estudado, também como um outdoor do modelo cristão goodllywoodiano.

No âmbito das tarefas do Autoajuda 2018, prescrições estritas relacionadas aos cuidados com a aparência foram apresentadas, tal qual aquelas relacionadas à mente, como formas de «agradar a Deus», como o excerto de uma tarefa dedicada ao tema da «discrição feminina» bem exemplifica:

Naquela época, as mulheres que vestiam de forma sensual diziam «eu sou prostituta.» Mas hoje, que a moda dita que a mulher deve se vestir de forma sensual, o que ela diz? O que ela quer? Quem ela quer chamar atenção e para quê?

[...] Você vai vestir o que vai glorificar o Seu Senhor neste próximo domingo. Você vai usar saia ou vestido, num comprimento perfeitamente discreto (nada de minissaia ou saia curta) e confortável, sem marcar nenhuma parte íntima, nada colado, nem transparente, pois a atenção que você quer não é dos homens e sim a do seu Senhor. E assim falar para Ele, através do seu vestir, o quanto você aprecia ter nascido mulher, que pode ser feminina sem precisar se igualar ao homem para ter valor nem direitos, e que não precisa usar o seu corpo para se sentir valorizada. (Cardoso 2018, Tarefa 5) 
No fragmento, a ideia de «valorização» do feminino circunscrita ao corpo perpassa, como na cultura pós-feminista, por um propósito de ressignificação do feminino, tal qual o ato de se mostrar a Deus o apreço por «ter nascido mulher» evidencia. Como denota o diálogo implícito entre a forma de apresentar este propósito e a máxima de Simone de Beauvoir, em O Segundo Sexo (1949), esta «ressignificação do feminino» é neste contexto realizada a partir de uma concepção biologista do gênero; de um entendimento desvirtuado do feminismo comumente referido nas falas de Cardoso e que, no caso do fragmento, se explicita pela ideia de que este é um movimento que reivindica o direito e o valor das mulheres enquanto sujeitos literalmente iguais aos homens; e de uma nítida relação de oposição entre o modelo «virtuoso» que propõe um modelo estereotipado da mulher feminista como a que «usa» o corpo para se sentir valorizada, deslegitimando, assim, a reivindicação da sexualidade feminina a ele atrelada.

\section{Feminilidade e comportamento}

A oposição entre o perfil de mulher godllywoodiano e o creditado como feminista no âmbito do programa é evidenciado, sobretudo, nas recomendações de ordem comportamental associadas à «performance feminina» ensejada no programa. No coração deste diagnóstico, está o fato de que, tal qual o modelo de mulher bem-sucedida que logra equilibrar carreira, família e lar é promovido como «empoderado» e «feminista» (Rottenberg 2018), o modelo Godllywood pauta-se pela neutralização das mesmas desigualdades de gênero que constituem a vida desta mulher multitarefas apresentando-a como «forte» e desejável aos olhos de Deus. Junto desta performance de sucesso, as mulheres são incentivadas a investir no seu «lado feminino»e, consoante a distorcida concepção de feminismo propagada no programa, a se afastarem do perfil «feminista» sendo "graciosas», «cuidadosas» e «maleáveis» - características apresentadas por Cardoso como opostas à ideia de «fraqueza» atribuída ao feminino e, por esta razão, rechaçadas por um suposto discurso mainstream de que as mulheres «devem ser iguais aos homens» (ver Tarefa 11).

Assente em prescrições de gênero biologistas, hierárquicas e patriarcais que acompanham o Pentecostalismo desde as suas origens e tornaram-se significativamente mais rígidas para as mulheres das Igrejas quando as leituras fundamentalistas-literalistas foram popularizadas no movimento, a ideia de "ser feminina» também se acomoda a domesticidade. Apresentada no âmbito do programa por meio de uma estética glamorizada que tem permeado igualmente a cultura popular pós-feminista sob o credo da «livre escolha», a domesticidade é o tema, por exemplo, numa tarefa em que, após as participantes serem incumbidas de limpar e organizar o lar, Cardoso finaliza o post com um comentário em que valoriza esta prática desafiando quem a problematiza: 
Depois de tudo arrumadinho, tire umas fotos e cole no seu diário para você lembrar dos momentos logo após toda essa arrumação... se você é como eu, vai fazer questão de antes de sair pela porta, dar mais uma olhadinha para traz (sic), suspirar profundamente e se alegrar de ter um cantinho tão gostoso de viver! [...]

Você vai ver como é bom aquilo que dizem ser tão degradante! (Cardoso 2018, Tarefa 8)

Para além da domesticidade, a submissão é também um tópico recorrente nas tarefas analisadas, tendo sido especialmente trabalhado naquelas em que as participantes são convocadas a deixarem de ser «orgulhosas» praticando ações como «submeter-se a seus maridos», não ter a pretensão de serem independentes, nem de emitirem suas opiniões sobre quaisquer assuntos (ver Tarefas 9 e 10). Nestas tarefas, assim como no fragmento anteriormente citado e nas demais nas quais o tema do comportamento associado à ideia de feminino são retomadas, a performance godllywoodiana é sempre apresentada de maneira assertiva, glamourizada, e em oposição à que é considerada feminista e identificada - e também distorcida - ao longo de todo programa (e além dele) por meio de referências mais ou menos explícitas ao movimento, suas lutas e agentes.

\section{Considerações finais}

Como revelou a análise do corpus selecionado para este artigo, o modelo de feminilidade tal como vem sendo apresentado pela IURD na última década aproxima-se dos credos que têm atravessado as «subjetividades neoliberais», apresentando soluções individualizadas para problemas estruturais de gênero. As relações traçadas com os feminismos a partir deste paradigma são, no entanto, de oposição, diferenciando-se, neste sentido, das expressões neoliberalizadas que, na sua contradição, pretendem reivindicá-los. No âmbito do Godllywood, como destacado na análise, os feminismos e seus agentes são invocados como antagonistas ao perfil de mulher idealizado pela Igreja, o qual, vale ressaltar, é fruto de uma construção social teologicamente justificada no contexto do Pentecostalismo - e de outras religiões de matriz cristã - desde os seus primórdios.

Acompanhando o crescente das dinâmicas polarizadas, marcadas pelo paradigma de ações e reações em torno dos debates sobre «gênero» e «feminismo» no Brasil, as retóricas empregadas na promoção do tradicional modelo de feminilidade propagado pela Igreja, como evidenciado, aproximaram-se estrategicamente das expressões neoliberalizadas dos feminismos nas disputas que têm marcado a política institucional e a paisagem midiática brasileira em torno do tema. Reproduzindo, desta feita, uma dinâmica de cooptação e esvaziamento político, tornam-se uma importante ferramenta meta-política nas disputas pelo senso comune, aliando-se às forças conservadoras na manutenção conveniente do status quo por meio de uma ideologia de gênero que serve política e economicamente à 
ordem patriarcal. Neste sentido, e no contexto referido, a retórica opera como antifeminista, podendo ser compreendida, como as coincidências entre o seu processo de emergência e adaptação evidenciaram, como parte do conjunto diversificado de reações antigênero no cenário da política nacional.

\section{Referências bibliográficas}

Banet-Weiser, Sarah. 2018. Empowered: Popular Feminism and Popular Misogyny. Durham: Duke Univeristy Press.

Banet-Weiser, Sarah, Rosalind Gill e Catherine Rottenberg. 2020. «Postfeminism, Popular Feminism and Neoliberal Feminism? Sarah Banet-Weiser, Rosalind Gill and Catherine Rottenberg in Conversation.» Feminist Theory 21(1): 3-24. DOI: https: / / doi.org/10.11 $77 / 1464700119842555$.

Bardin, Laurence. 2011. Análise de Conteúdo. Coimbra: Edições 70.

Bowler, Kate. 2013. Blessed: A History of the American Prosperity Gospel. New York: Oxford University Press.

Campos, Roberta Bivar Carneiro, e Alana Souza. 2017. «Godllywood de Cristiane Cardoso: uma etnografia do 'transreligioso'.» Revista de Antropologia 60(2): 487-512. DOI: http: / / dx.doi.org/10.11606/2179-0892.ra.2017.137318.

Corrêa, Sonia, e Isabela Kalil. 2020. Politicas Antigénero en América Latina: Brasil - ¿La Catástrofe Perfecta? Rio de Janeiro: Sexuality Policy Watch (SPW).

Corredor, Elizabeth S. 2019. «Unpacking 'Gender Ideology' and the Global Right's Antigender Countermovement.» Signs 44(3): 613-38. DOI: https: / / doi.org/10.1086/ 701171.

Dip, Andrea. 2018. Em nome de quem? A bancada evangélica e o seu projeto de poder. Rio de Janeiro: Civilização Brasileira.

Ferreira, Carolina Branco de Castro. 2015. «Feminism on the Web: Lines and Forms of Action in Contemporary Feminist Debate.» Cadernos Pagu 44: 199-228.

Ferreira, Isabelle Azevedo. 2019. «A ação política contra o feminismo: uma análise a partir do Movimento Brasil Livre (MBL).» In $42^{\circ}$ Congresso Brasileiro de Ciências da Comunicação, Belém, 2 a 7/09/2019, 1-15.

Ferreira, Salomé Margot Melo, e Edil Ferreira Silva. 2019. «'Não nos representam!': da crise de legitimidade feminista no discurso de mulheres do Movimento Brasil Livre MBL.» Caderno Espaço Feminino 32(2): 23-48. DOI: http: / / dx.doi.org/10.14393/CEF-v 32n2-2019-2.

Genz, Stephanie, e Benjamin A. Brabon. 2009. Posfeminism: Cultural Texts and Theories. Edinburgh: Edinburgh University Press.

Gill, Rosalind. 2007. «Postfeminist Media Culture: Elements of a Sensibility.» European Journal of Cultural Studies 10(2): 147-66. DOI: https: / / doi.org/10.1177/1367549407075898.

Gill, Rosalind. 2008. "Culture and Subjectivity in Neoliberal and Postfeminist Times.» Subjectivity 25(1): 432-45. DOI: https:/ / doi.org/10.1057/ sub.2008.28.

Gill, Rosalind. 2017. «The Affective, Cultural and Psychic Life of Postfeminism: A Postfeminist Sensibility 10 Years On.» European Journal of Cultural Studies 20(6): 606-26. DOI: https: / / doi.org/10.1177 / 1367549417733003.

Gill, Rosalind, e Christina Scharff. 2011. «Introduction.» In New Femininities: Postfeminism, Neoliberalism and Subjectivity, organizado por Rosalind Gill e Christina Scharff, 1-18. London: Palgrave Macmillan. 
Giraldo, Isis. 2016. «Coloniality at Work: Decolonial Critique and the Postfeminist Regime.» Feminist Theory 17(2): 157-73.

hooks, bell. 1984. Feminist Theory: From Margin to Center. Boston: South End Press.

Lazar, Michelle M. 2007. «Feminist Critical Discourse Analysis: Articulating a Feminist Discourse.» Critical Discourse Studies 4(2): 141-64. DOI: https://doi.org/10.1080/174059 00701464816.

Machado, Maria das Dores Campos. 1999. «SOS Mulher - a identidade feminina na mídia pentecostal.» Ciencias Sociales e Religión 1(1): 167-88.

Machado, Maria das Dores Campos. 2018. «O discurso cristão sobre a 'ideologia de gênero'.» Revista Estudos Feministas 26(2): 1-18. DOI: https://doi.org/10.1590/1806-9584-2018v 26 n247463.

Martinez, Monise. 2018. «Pós-Feminismo no Reino de Deus: reflexões sobre as ambiguidades de um percurso 'virtuoso'.» Cabo dos Trabalhos 17. https://cabodostrabalhos.ces. uc.pt/n17/ensaios.php.

Martino, Luís Mauro Sá. 2017. Mídia, Religião e Sociedade: das palavras às redes digitais. São Paulo: Paulinas.

Matos, Carolina. 2017. «New Brazilian Feminisms and Online Networks: Cyberfeminism, Protest and the Female 'Arab Spring'.» International Sociology 32(3): 417-34. DOI: https:// doi.org/10.1177/0268580917694971.

McRobbie, Angela. 2004. «Post-Feminism and Popular Culture.» Feminist Media Studies 4(3): 255-64. DOI: https://doi.org/10.1080/1468077042000309937.

McRobbie, Angela, e Jonathan Ross. 2011. «Beyond Post-Feminism.» Public Policy Research 18(3): 179-84.

Norocel, Ov Cristian. 2018. «Antifeminist and 'Truly Liberated': Conservative Performances of Gender by Women Politicians in Hungary and Romania.» Politics and Governance 6(3): 43-54. DOI: https://doi.org/10.17645/pag.v6i3.1417.

Payne, Leigh A., e Andreza Aruska de Souza Santos. 2020. «The Right-Wing Backlash in Brazil and Beyond.» Politics and Gender 16(1): 32-38.

Pinheiro-Machado, Rosana. 2019. Amanhã vai ser maior: o que aconteceu com o Brasil e possíveis rotas de fuga para a crise atual. São Paulo: Planeta.

Prügl, Elisabeth. 2015. «Neoliberalising Feminism.» New Political Economy 20(4): 614-631. DOI: https://doi.org/10.1080/13563467.2014.951614.

Reis, Josemira Silva. 2017. «Feminismo por hashtags: as potencialidades e riscostecidos pela rede.» Seminário Internacional Fazendo Gênero 11 \& $13^{\text {th }}$ Women's Worlds Congress (Anais Eletrônicos), Florianópolis, 1-13.

Rottenberg, Catherine. 2018. The Rise of Neoliberal Feminism. New York: Oxford University Press.

Sullivan, Katie Rose, e Helen Delaney. 2016. «A Femininity That 'Giveth and Taketh Away': The Prosperity Gospel and Postfeminism in the Neoliberal Economy.» Human Relations, 70(7): 836-859. DOI: https: / / doi.org/10.1177/0018726716676322

Teixeira, Jacqueline Moraes. 2012. «Corpo e sexualidade: os direitos reprodutivos na Igreja Universal do Reino de Deus.» Mandrágora 18(18): 53-80.

Teixeira, Jacqueline Moraes. 2014. «Mídia e performances de gênero na Igreja Universal: o Desafio Godllywood.» Religião e Sociedade 34(2): 232-256. 
Monise Martinez. Doutoranda em Estudos Feministas no Centro de Estudos Sociais da Universidade de Coimbra, com projeto de tese financiado pela Fundação para Ciência e Tecnologia (FCT). Mestre em Estudos Editoriais pela Universidade de Aveiro, Portugal. Bacharel em Letras pela Universidade de São Paulo, Brasil.

Endereço eletrônico: martinezmonise@gmail.com

Artigo recebido em 13 de julho e aceite para publicação em 7 de outubro de 2020. 


\title{
SURFANDO NA ONDA DIGITAL: FEMINISMOS EM REDE NO BRASIL
}

\author{
Raguel de Barros Pinto Miguel * \\ (D) https: / / orcid.org/0000-0003-2042-7223 \\ Djenifer Samantha Marx \\ (D) https: / / orcid.org/ 0000-0003-3435-3464 \\ Gilmara Joanol Arndt
}

(D) https: / / orcid.org/0000-0003-0245-1801

\section{Resumo}

Este artigo tem a proposta de desenvolver reflexões sobre a relação entre feminismos e as mídias digitais, a partir do atual contexto social e político brasileiro. $\mathrm{O}$ artigo explora o modo como o movimento feminista tem se apropriado do meio digital como espaço de divulgação de suas pautas. As discussões apontam para a presença de uma dualidade em relação ao feminismo digital: ao mesmo tempo em que se apresenta como um espaço de militância e de visibilidade, suas pautas são apropriadas e mercantilizadas, tornando-se alvo de disputas mercadológicas. Porém, mesmo em meio a embates políticos, ataques conservadores e fortalecimento de preceitos neoliberais, as ações feministas ligadas à esfera digital têm cumprido um papel central de luta e resistência.

Palavras-chave: Feminismo, feminismo digital, mídia, quarta onda.

\section{Abstract}

\section{Surfing the digital wave: Network feminisms in Brazil}

This article aims to develop reflections on the relationship between feminisms and digital media, based on the current Brazilian social and political context. It explores the ways in which the feminist movement has appropriated the digital medium as a space for disseminating its agendas. The analysis points to the presence of a duality concerning digital feminism: at the same time that it presents itself as a space of militancy and visibility, its agendas are appropriated and commodified, becoming the target of market disputes. However, even amid political clashes, conservative attacks and the strengthening of neoliberal precepts, feminist actions linked to the digital sphere have played a central role in struggle and resistance.

Keywords: Feminism, digital feminism, media, fourth wave.

\footnotetext{
* Departamento de Psicologia, Universidade Federal de Santa Catarina - UFSC, Florianópolis, Santa Catarina; CEP: 88050-300 Brasil.

Endereço postal: Universidade Federal de Santa Catarina - UFSC, Florianópolis - SC; CEP: 88050-300 Brasil.

Endereço eletrônico: raquelbarros@hotmail.com

** Universidade Federal de Santa Catarina - UFSC

Florianópolis - SC; CEP 88.036-400; Brasil

Endereço eletrônico: djeni.marx@hotmail.com

***: Universidade Federal de Santa Catarina - UFSC

Florianópolis - SC; CEP: 88.063-300; Brasil

Endereço eletrônico: gilmaraarndt@gmail.com
} 


\section{Résumé}

\section{Surfer sur la vague digital: Les féminismes en réseau au Brésil}

Cet article vise à développer des réflexions sur la relation entre les féminismes et les médias digitaux, basées sur le contexte social et politique brésilien actuel. La recherche a exploré comment le mouvement féministe s'est approprié du support digital comme un espace pour diffuser ses lutes. Les discussions soulignent la présence d'une dualité par rapport au féminisme digital: en même temps qu'il se présente comme un espace de militantisme et de visibilité, ses agendas sont appropriés et commercialisés, devenant la cible de conflits de marché. Cependant, même au milieu des affrontements politiques, des attaques conservatrices et du renforcement des préceptes néolibéraux, les actions féministes liées à la sphère digital ont joué un rôle central dans la lutte et la résistance.

Mots-clés: Féminisme, féminisme numérique, médias, quatrième vague.

\section{Introdução}

A presença do meio digital tem se tornado a cada dia mais marcante no mundo contemporâneo. Blogues, redes sociais, mensagens instantâneas, vídeo-chamadas, sites, posts, lives, stories estão inseridos no cotidiano, construindo novas formas de se relacionar e de interagir. Assim, as redes sociais digitais podem ser consideradas um importante espaço de produção de sentidos, possibilitando novas formas de significação da realidade política, econômica e afetiva (Dias 2018).

Nessa perspectiva, partimos da ideia de que a mídia contribui para a construção de subjetividades ao prescrever e perpetuar modos de ser e de estar no mundo. Da mesma forma em que perpetuam padrões de masculinidade e feminilidade, as novas tecnologias da informação e da comunicação abrem a possibilidade de utilização da mídia para transformação de estereótipos e, ainda, como plataforma de atuação feminista (Pedro e Lemes 2019; Hollanda 2018).

Diante desse cenário, os movimentos feministas têm utilizado os meios digitais como espaço de expansão e mobilização do movimento. As novas formas de articulação social mediadas pelas redes sociais digitais têm possibilitado um novo formato de ativismo, que tem sido chamado de net-ativismo (Babo 2017). Por meio dessa nova configuração de protesto público, a Internet estabelece-se como um espaço de disseminação, organização e mobilização da ação coletiva.

Com relação à noção de feminismo, é importante destacar seu caráter polissêmico. De acordo com Hawkesworth $(2006,746)$, «o feminismo tem sido concebido de maneira muito ampla, como uma ideia, um conjunto de convicções, uma ideologia, um movimento social, e uma práxis». Assim, ao falar de «feminismos», ou «movimento feminista», faz-se referência a uma multiplicidade de posições e entendimentos sobre esses conceitos.

Nesse sentido, o movimento feminista é atravessado por uma pluralidade de sujeitos e perspectivas, que vão marcar a sua história de transformações, avanços 
e contradições (Pinto 2003). Trata-se de um campo teórico, mas também de um lugar político, de modo que «vozes marcadas por diferenças geográficas, sexuais, étnicas, raciais, religiosas, geracionais, convivem, dialogam, disputam e se intersectam, acentuando-se reciprocamente, em variações que muitas vezes nos escapam» (Schmidt 2004, 17).

Tal pluralidade ganha visibilidade no meio digital, contribuindo para expansão dos discursos feministas e a popularização do movimento. Essa popularização, ao mesmo tempo em que possibilita a abertura de novos espaços para performances feministas, também abriga, por outro lado, uma possível pasteurização, vulgarização e mercantilização do movimento. Dessa forma, em um contexto marcado pelos preceitos e práticas neoliberais que se coadunam com a ideia de um «pós-feminismo», ou um «feminismo de mercado», alinhados a uma agenda neoliberal, os ideais feministas acabam sendo cooptados para fins mercadológicos.

Neste artigo, tomamos o neoliberalismo como a face atualizada do capitalismo contemporâneo. Ao longo da história, o capitalismo já passou por diferentes fases e, independentemente dos aspectos que ganharam destaque em um momento ou em outro, algumas características são centrais nesse sistema econômico, social e político. Ao lado do crescimento econômico, da inovação tecnológica e de transformações nas condições materiais de vida, acompanhamos, por exemplo, o avassalador aumento das desigualdades, da precariedade, do trabalho alienante e da destruição do meio ambiente; sempre pautados em um modo de produção que prioriza o lucro em detrimento do humano (Wright 2019)

Vale ressaltar que o modo de produção capitalista não afeta somente o sistema econômico, ele diz respeito, diretamente, à construção de modos de estar no mundo. Nesse sentido, entendemos que o neoliberalismo é mais do que um sistema econômico, sendo também uma racionalidade política dominante, um modo de governança não limitado ao Estado, que produz, através de práticas, discursos e políticas, sujeitos e subjetividades específicas (Rottenberg 2014). Dessa forma, o sujeito do neoliberalismo é visto como um «empreendedor de si mesmo», que deve exercer sua autonomia (aqui entendida como capacidade e responsabilidade de autocuidado e de prosperar em termos financeiros) através de cálculos de custo-benefício, disseminando os valores de mercado em todas as esferas da vida, inclusive as mais privadas.

Na esfera política, a produção do sujeito neoliberal se dá intimamente relacionada à ideia de autossuficiência, eficiência e capacidade individual. Tal ideal de sujeito está atrelado a um projeto amplo de desmantelamento de políticas públicas, bem como de noções de justiça social, usurpando o conceito de cidadania «ao produzir identidades econômicas como base para a vida política» (Rottenberg 2014, 421). Assim, a cidadania não é praticada na coletividade e no interesse público, mas, como aponta Brown (2003), o próprio corpo político deixa de existir, dando lugar a um grupo disperso de empresários individuais e consumidores. 
Tais questões também vão se refletir nos feminismos contemporâneos, na medida em que ideais feministas convergem com ideais neoliberais. Esta questão é discutida com maestria por Nancy Fraser (2019), ao refletir sobre os caminhos percorridos pelo feminismo de segunda onda ${ }^{1}$ estadunidense. Caminhos, estes, que apontam para uma ressignificação de pautas feministas, onde ideais emancipatórios tornam-se ambíguos quando sob a égide do neoliberalismo.

Especificamente no cenário brasileiro, o projeto neoliberal se dá atrelado à ascensão de discursos anti-democráticos, conservadores, homofóbicos, misóginos e racistas, em um contexto de acirramento de disputas políticas em todas as esferas do poder. Na esfera executiva, seu ápice foi em 2016 com o golpe que destituiu a presidenta Dilma Rousseff. Desde então, o conservadorismo vem galgando a passos largos. Políticas públicas vêm sendo desmanteladas, direitos são cerceados a cada dia.

Em resposta aos crescentes ataques - que se materializam na intensificação de discursos conservadores e fundamentalistas e no entrave a propostas políticas voltadas para mulheres e população LGBTI - assistimos ao crescimento de um movimento de resistência feminista que se manifesta das mais diversas formas. Assim, mulheres disputam as ruas, os espaços digitais e os veículos midiáticos. Mobilizam marchas, performances artísticas, criam conteúdos, produzem intelectualmente, fazendo uso principalmente das redes sociais digitais para amplificação das pautas feministas.

Diante do que foi exposto, o presente artigo tem a intenção de desenvolver reflexões sobre a relação entre feminismos e as mídias digitais, a partir do atual contexto social e político brasileiro. As discussões girarão, especialmente, em torno de dois eixos. O primeiro refere-se ao modo como o movimento feminista no Brasil tem se apropriado do meio digital como espaço de divulgação de suas pautas. Para tanto recorreremos a exemplos de práticas feministas nas redes sociais brasileiras, construindo reflexões acerca dessas práticas a partir do diálogo com autores/as que têm se debruçado sobre o tema. Ressaltamos que, uma vez que este artigo compreende um ensaio teórico acerca do feminismo digital no Brasil, as consultas às redes sociais deram-se de maneira informal, não constituindo uma pesquisa de base empírica.

O segundo eixo está voltado para reflexões sobre a apropriação, popularização - e possível mercantilização - das agendas feministas por esse mesmo meio digital. Entendemos que esse processo de apropriação - que não acontece sem disputas, tensões e negociações - vai se expressar de diferentes formas, produ-

Nas classificações mais frequentes, costuma-se dividir o movimento feminista em «ondas». Contudo, por ser uma periodização artificial, apresenta limitações, já que não contempla as diversidades e nuances de cada geração de feministas e pode sugerir que determinadas características e demandas de um período não estão presentes nas mobilizações anteriores. Porém, a metáfora das ondas remete à fluidez característica do movimento, que acompanha avanços e retrocessos, novas pautas e novas discussões para pautas antigas. 
zindo efeitos distintos. Contudo, o foco escolhido para este eixo foi o femvertising, uma tendência publicitária que aqui é tomada como uma das facetas da cooptação de pautas feministas para fins mercadológicos, embora não seja a única. Cabe destacar que esta discussão estará pautada, especialmente, na pesquisa sobre o tema realizada por Arndt e Miguel (2019). ${ }^{2}$

\section{Feminismos digitais no contexto brasileiro: práticas em rede}

Nesse primeiro eixo da discussão, buscaremos refletir sobre a articulação entre os feminismos contemporâneos e as mídias digitais, tomando como exemplo algumas das ações feministas desenvolvidas por meio da Internet no contexto brasileiro. Para tanto, cabe fazer uma breve apresentação desse nova fase do movimento feminista no Brasil, que algumas autoras vão chamar de «quarta onda feminista» (Pedro e Lemes 2019; Hollanda 2018).

No Brasil, costuma-se situar seu surgimento na década de 2010, utilizando-se como marco a realização da primeira edição da Marcha das Vadias. Inspirada na Slutwalk, que aconteceu no mesmo ano no Canadá, a marcha teve como pauta «o fim da violência sexual e da culpabilização da vítima, bem como a liberdade e a autonomia das mulheres sobre seus corpos» (Gomes e Sorj 2014, 437). Com o auxílio da Internet, a manifestação rapidamente ganhou repercussão internacional e passou a ser replicada, ainda em 2011, em diferentes países. A marcha, que tem sido realizada anualmente em diferentes cidades do Brasil, é organizada de forma local, autônoma e descentralizada (Gomes e Sorj 2014).

Nesse contexto, plataformas digitais como Facebook, Youtube, Twitter, Whatsapp, além de blogues e websites têm constituído importantes ferramentas para organização dessas manifestações. A velocidade oferecida pelas novas tecnologias proporciona ao ativismo político uma agilidade de organização e de divulgação de suas lutas sem precedentes (Gomes e Sorj 2014). Tais transformações, por sua vez, é que vão caracterizar este novo período do feminismo brasileiro - em articulação com os feminismos de outras parte do globo - como uma «quarta onda».

Para autoras como Perez e Ricoldi (2018), haveria no feminismo de quarta onda uma maior democratização na construção e divulgação de ideias feministas, uma vez que a Internet e as novas plataformas digitais permitem que qualquer pessoa com acesso à rede possa criar e compartilhar textos e vídeos - especialmente através das redes sociais. Assim, é importante enfatizar o potencial

As discussões acerca do femvertising estarão centradas nas informações advindas da pesquisa realizada por duas das autoras deste presente artigo. A referida pesquisa, assim como o tema discutido neste texto, fazem parte do projeto de pesquisa «Novas ondulações do feminismo», desenvolvido por pesquisadoras do NUGEMS - Núcleo de Estudos em Ações em Gênero, Educação, Mídia e Subjetividade, da Universidade Federal de Santa Catarina. 
de alcance que as redes virtuais possuem, com conteúdos que «viralizam», atingindo um público extremamente diverso e introduzindo tópicos a serem debatidos, inclusive, dentro da mídia mainstream (Albu 2017). Contudo, é importante atentar-se para o fato de que as características do meio digital que possibilitam a expansão dos feminismos - como a capacidade de reprodutibilidade e a garantia de anonimato - também produzem formas de violência (Banet-Weiser 2018), em que podemos citar como exemplo, a «pornografia de vingança» e o «cyberbullying».

Pela sua alta reprodutibilidade, a Internet também proporciona a construção e divulgação de diversas vertentes feministas. Nesse contexto, importantes produções intelectuais são revisitadas à luz de questões atuais, ganhando nova repercussão. É o caso do conceito de interseccionalidade, desenvolvido por Kimberlé Crenshaw (1989) enquanto uma ferramenta para o entendimento de múltiplas opressões que se articulam a partir do intercruzamento de marcadores como raça, gênero, classe, dentre outros (Crenshaw 1989).

Diante das condições conferidas pelo espaço digital, autoras como Peres e Ricoldi (2018) consideram que a pauta da interseccionalidade, levantada pelas feministas acadêmicas da onda anterior, efetiva-se no ciberespaço, onde há possibilidade para uma expressão direta e um protagonismo plural. É nesse cenário que grupos como o movimento de mulheres negras, lésbicas, de pessoas trans e pessoas com deficiência, entre outros, encontram espaço para difundir suas reflexões teóricas, suas lutas e agendas, conquistando maior visibilidade.

Além da ampla divulgação de diversas vertentes feministas e da organização de manifestações, as redes também participam na construção de grupos e comunidades virtuais. São estimuladas ações de colaboração entre mulheres por meio de comunicações digitais, que possibilitam a conexão entre pessoas de todas as partes do país e do mundo. Assim, são criados grupos virtuais, principalmente no Facebook, de caráter «secreto» ou «fechado», que servem como espaço para diálogo, reflexão e ajuda, a partir de temas caros ao movimento feminista. Denúncias de assédio sexual, agressão, estupro, solicitação de informações sobre aborto seguro podem ser localizadas nesses grupos.

Experiências de violência e abuso também podem ser publicizadas nas mídias digitais por meio de posts pessoais e uso de hashtags. A partir de relatos e denúncias, visualiza-se a dimensão estrutural de opressões vividas individualmente. É o caso das campanhas \#primeiroAssédio e \#MeuAmigoSecreto, ambas lançadas em 2015 por iniciativas de coletivos feministas. As campanhas incentivaram meninas e mulheres a contar situações de abuso, assédio e agressão, em suas redes sociais, por meio do uso das hashtags. Ao promover um debate público sobre o assédio sexual, ambas as campanhas colocaram em evidência a dimensão da violência presente nas experiências de diferentes mulheres, desnaturalizando-a.

Nesse mesmo sentido, temos as campanhas «Chega de Fiu Fiu» e \#Vamos Juntas, contra o assédio sexual em espaços públicos, que estimularam ações de 
colaboração e união entre mulheres, no caminho de um enfrentamento a essas situações. A primeira campanha começou em 2013 e teve como objetivo mapear os pontos das cidades brasileiras que apresentam maior risco de assédio às mulheres. Em 2014, foi lançado, então, um mapa interativo ${ }^{3}$, onde tem sido possível localizar os pontos nas cidades brasileiras com uma maior incidência de assédio às mulheres.

Já a campanha \#VamosJuntas foi lançada no Facebook, em 2015. Começou como um convite, lançado pela jornalista Babi Souza em seu perfil nessa rede social, para que mulheres, ao andarem nas ruas, passassem a oferecer companhia umas às outras. Desde então, por meio da hashtag \#VamosJuntas, mulheres de todo o Brasil passaram a lançar seus relatos nas redes digitais para contar sobre suas experiências de oferecer companhia a outras mulheres nas ruas.

A partir das contribuições de Cristiane Dias (2018) é possível dizer que tais iniciativas extrapolam a esfera virtual, na medida em que produzem efeitos materiais nos modos de habitar as cidades. Diante desse contexto, pode-se retomar o conceito de ciberfeminismo, enquanto uma forma de expressão do movimento feminista, na interface do espaço real e virtual da sociedade civil. O ciberespaço oferece uma alternativa aos espaços offline, através de um acesso facilitado, considerando a concentração territorial de oportunidade e as barreiras geográficas. Desta forma, podemos dizer que as novas plataformas digitais possibilitam novas formas de ativismo ciberfeminista, apresentando uma diversidade de estratégias para engajar-se no movimento, especialmente através de micropolíticas de participação (Albu 2017).

Nesse contexto, as ações de 2015, mobilizadas pelas hashtags e protagonizadas por mulheres, deram corpo ao que a imprensa chamou de «Primavera Feminista» (Pedro e Lemes 2019; Hollanda 2018). Diante do retrocesso no Congresso Nacional brasileiro, como a apresentação do Projeto de Lei n ${ }^{\circ}$ 5069/2013 - que previa dificultar o acesso ao aborto seguro, nos casos de estupro e, se aprovado, poderia restringir até mesmo a venda da «pílula do dia seguinte» nas farmácias milhares de mulheres novamente saíram às ruas das cidades brasileiras.

Desta forma, as mobilizações feministas no Brasil se dão no embate com o avanço de uma agenda conservadora e neoliberal nas diferentes esferas do poder. Assim, é possível dizer que a quarta onda feminista em nosso país é atravessada pela transformação política da última década (Pedro e Lemes 2019). Dentre os muitos acontecimentos que marcaram este período, alguns merecem ser destacados, já que dizem respeito ao modo como questões relacionadas a gênero e sexualidade passaram a ser utilizados como objeto de disputa política e elemento de campanha eleitoral.

Nesse cenário, destaca-se a participação da Frente Parlamentar Evangélica (FPE), multipartidária, composta por deputados estaduais e federais vinculados,

http://chegadefiufiu.com.br/ 
principalmente, a instituições evangélicas neopentecostais. A FPE foi criada em 2003 para representar as pautas e interesses da comunidade evangélica no parlamento brasileiro e, por isso, fazer oposição a projetos que considerem ferir os preceitos bíblicos (Quintão 2017). Suas proposições têm representado entraves às mulheres e à população LGBTI no acesso a direitos.

Uma das principais disputas se dá em torno dos direitos sexuais e reprodutivos. Se por um lado, a discussão em torno da violência contra a mulher avança com a Lei Maria da Penha, aprovada em 2006 e a tipificação do feminicídio, aprovada em 2015 - o aborto seguro ainda é tema de intenso debate, sendo um dos principais alvos da FPE no parlamento. Nesse sentido, Díaz-Benítez e Gonçales $(2018,164)$ destacam que, durante o governo da presidenta Dilma Roussef, a «legalização do aborto se tornou uma espécie de pedágio através do qual o governo, em troca de alianças, exerceria um modo estatal de controle do corpo das mulheres.»

Um segundo exemplo é a discussão em torno da «ideologia de gênero», neologismo utilizado para descrever uma suposta agenda político-ideológica que - através da abordagem, especialmente nas escolas, de questões referentes à sexualidade e gênero - é tida como uma ameaça às crianças e à família tradicional (Sombrio e Miguel no prelo). O debate em torno da «ideologia de gênero» no contexto brasileiro foi encabeçado pela ala conservadora da Igreja Católica e teve apoio de entidades evangélicas neopentecostais e, ainda, de grupos laicos. Entre aqueles que se posicionam contrariamente à discussão de temáticas relativas a gênero e sexualidade nas escolas, predomina o argumento da garantia de proteção às crianças e à família.

Assim, a suposta «ideologia de gênero» tem sido pauta constantemente levantada para mobilizar a opinião pública contra os movimentos feministas e LGBTI, marcando o discurso de diferentes agentes políticos. Percebe-se, então, um movimento duplo com relação ao feminismo no Brasil: ao mesmo tempo em que ele se populariza, ganhando destaque e espaço no mundo digital e nas ruas, assiste-se a uma ofensiva antigênero de grandes proporções. Por ofensiva antigênero são compreendidas as ações mobilizadas por alas conservadoras em diferentes pontos do globo, constituindo pauta, inclusive, de candidatos políticos em suas campanhas eleitorais.

É o caso de Jair Bolsonaro, atual presidente da República, eleito em 2018. Bolsonaro ficou conhecido pela mídia, sobretudo por suas declarações de cunho homofóbico, misógino, racista, de negação dos acontecimentos da Ditadura Militar brasileira, de ataque aos Direitos Humanos e aos movimentos sociais. Cabe ressaltar que sua campanha contou, ainda, com intensa utilização das redes sociais para difusão de notícias falsas (fake news) a fim de atingir seus adversários políticos. ${ }^{4}$

As fake news com destaque durante a campanha eleitoral tinham foco nas temáticas de gênero e sexualidade: falsas informações sobre a distribuição nas escolas de um suposto «kit gay» e ainda de mamadeiras eróticas, com bico em formato de pênis para crianças; apontando mais uma vez para a centralidade desses temas no discurso político de Bolsonaro. 
Em resposta à sua candidatura, às vésperas do primeiro turno das eleições, mulheres de todo o país voltaram às ruas, mobilizadas pela campanha \#EleNão. Organizada por meio de um grupo no Facebook, intitulado «Mulheres contra Bolsonaro» - que chegou a reunir 3,8 milhões de membros - a campanha de oposição à candidatura de Bolsonaro tomou as ruas de cerca de 114 cidades do Brasil e de outros locais do mundo, como Londres, Nova York, Lisboa e Paris. Estiveram presentes mulheres e homens de diferentes espectros políticos e de vinculações muito plurais, atores de TV, movimentos sociais, torcidas organizadas. Para especialistas do movimento feminista brasileiro, \#EleNão foi a maior manifestação de mulheres da história do país, que chegou a levar mais de 100 mil pessoas às ruas, restituindo «a cidade como espaço e elemento constitutivo do encontro e de uma democracia que não se resume ao voto» (Silva e Gorsdorf 2020, 648).

Apesar de sua importância histórica, a manifestação não foi suficiente para impedir a vitória de Jair Bolsonaro. Desde sua posse ele vem exercendo uma governança pautada em uma agenda neoliberal, por meio de ações que precarizam as relações de trabalho, desvalorizam os direitos humanos e invisibilizam as minorias. Contexto que, por sua vez, exige da mobilização de mulheres uma participação cada vez mais atuante e articulada, deixando evidente que os feminismos brasileiros seguem vivos e necessários nos enfrentamentos ao conservadorismo brasileiro.

\section{Femvertising: feminismo à venda?}

Nesta seção, serão apresentadas as reflexões produzidas a partir do segundo eixo de discussão. Sob esse eixo, buscamos discutir o modo como o discurso publicitário se atualiza a partir de temáticas caras aos feminismos contemporâneos. Entendemos que os dois eixos de nossa discussão se articulam na medida em que o meio digital fornece novas bases para a multiplicação de discussões feministas que, por sua vez, são apropriadas nas produções publicitárias e novamente voltam a circular no meio digital, dessa vez, atualizadas sob o crivo publicitário. Uma retroalimentação que coloca em circulação - não sem tensões e resistências - um «outro feminismo», mais palatável ao gosto neoliberal.

Nesta segunda parte da reflexão, portanto, retomamos a compreensão de que o capitalismo neoliberal não se traduz apenas em um modo de produção econômica, mas também em um modo de subjetivação, que se dá, dentre outras vias, pela construção de um imaginário, um ethos, capilarizando-se em todas as esferas da vida (Safatle 2015), como já mencionado. Do mesmo modo, propomos que a junção entre «feminismo e capitalismo» contemporâneos não se dá apenas no nível da construção de uma agenda política, mas também na produção de um certo «ethos feminista», que se dá pela via de uma experiência de identificação individualizada com os feminismos e, por vezes, materializada pela via do consumo. 
Nesse contexto, o femvertising parece corresponder a essa convergência entre ideais feministas e neoliberais, na medida em que faz uso de uma certa retórica feminista mais popularizada nas mídias digitais, justamente aquela que mais se adequa ao discurso da "gestão empreendora de si». Um exemplo seriam os usos, tão em voga atualmente, de termos como «empoderamento» ou «representatividade». Ambos, em sua versão adaptada ao léxico neoliberal, dão a entender que basta que algumas mulheres ocupem lugares de poder para que se considere uma ascensão à equidade/igualdade de todo o grupo de mulheres - questões que serão explicitadas a seguir.

O femvertising é uma tendência publicitária que parte da tentativa de produzir anúncios que abram mão dos velhos estereótipos de gênero, escapando à tradição publicitária de associar feminilidade à subalternidade e objetificação. $\mathrm{O}$ termo, que é formado a partir da junção das palavras em inglês advertising e feminism, foi apresentado em 2014, pelo Instituto SheKnows, durante o Advertising Week, evento internacional de publicidade que acontece anualmente em Nova York (Arndt e Miguel 2019). Tais publicidades têm ganhado visibilidade entre grandes marcas e o reconhecimento de consumidoras, tendo como principal espaço de divulgação as redes sociais digitais. Assim, o meio digital proporciona uma especificidade ao femvertising, uma vez que o espaço de envolvimento online possibilita a participação ativa das consumidoras, principalmente por meio do compartilhamento dos conteúdos publicitários, o que acarreta publicidade adicional para as empresas.

Essas movimentações, por meio do trabalho dos/as consumidores/as, possibilitam às marcas uma expansão do alcance de suas publicidades e produtos. Por outro lado, também possibilitam a expansão de discursos feministas pelo viés publicitário, o que, por sua vez, faz circular outros sentidos atrelados ao feminismo. Para exemplificar o alcance do femvertising no meio digital, é possível citar a campanha publicitária da marca Avon, lançada em 2016 no Brasil. Em menos de 24 horas após o seu lançamento, a campanha, sob o título «Dona dessa Beleza»5, teve mais de 14.500 curtidas e mais de 11.000 descurtidas no canal da marca no Youtube (Arndt e Miguel 2019).

Certamente o femvertising não é a única expressão da aproximação entre feminismo e capitalismo. Como mencionado no início do texto, Fraser (2019) explora essa questão, assim como Elisabeth Prügl (2015), refletindo a respeito de uma possível neoliberalização do feminismo. Cabe ressaltar que trazemos aqui uma discussão não sobre feminismos que sejam, declaradamente, neoliberais, mas sim a respeito do fato de que, por estarmos mergulhados em um contexto no qual reina o modo de produção capitalista - aliado ao pensamento neoliberal - escapar do «circuito de afetos» (Safatle 2015) criado por esse sistema econômico não parece ser uma opção.

5 https: / / www.youtube.com/watch?v=d34Xs45k5R0. 
Ao tratar da relação feminismo e neoliberalismo, Johana Oksala (2019) defende que o aspecto mais traiçoeiro deste pensamento para o feminismo seria a ênfase na «livre escolha». O fato de a liberação das mulheres estar associada, na lógica neoliberal, às suas escolhas individuais, acaba por invisibilizar - e aumentar - as desigualdades entre as diferentes mulheres e entre homens e mulheres, uma vez que aspectos políticos e sociais se esvaziam diante da lógica individualista.

Nesse sentido, é possível pensar sobre o uso exaustivo de palavras como «desejo», «vontade» e «escolha» em anúncios publicitários. Trata-se de elementos há muito utilizados na propaganda para garantir que o consumo seja concebido como ato de vontade, fruto de escolhas individuais (Rocha 2001). No contexto do femvertising tais termos passam a ser vinculados a um pretenso discurso feminista, na sua versão mais palatável e neoliberal, onde autonomia, liberdade e empoderamento são pensadas, somente, do ponto de vista individual e atreladas à elevação da autoestima (Arndt e Miguel 2019).

Esses aspectos são reforçados, ainda, no modo como o femvertising explora a associação entre beleza e feminilidade. De acordo com Arndt e Miguel (2019), nesses anúncios, essa relação é apresentada por meio de uma mensagem de auto-ajuda, onde o exercício de sentir-se bonita deriva de um esforço individual, por uma aceitação interior e não mais externa. Ao colocar o peso da autoestima no corpo das mulheres, esse discurso mascara os mecanismos estruturais racistas e sexistas construídos para minar a confiança dessas mulheres, muitas vezes ligados às mesmas marcas que produzem tais anúncios.

Ainda no que tange a essa questão, é importante considerar a repercussão que campanhas classificadas como femvertising causam nas redes sociais. Certamente que o número de curtidas é uma valiosa moeda, porém cabe refletir, também, sobre as «descurtidas». O fato de apresentarem em suas campanhas mulheres que fogem ao padrão tradicional, fazendo desfilar pelas telas mulheres gordas, negras, com deficiência, lésbicas, trans, entre outras, suscita não apenas reações emocionadas, mobilizadas por um sentimento de identificação com a mensagem. De acordo com Arndt e Miguel (2019), reações de descontentamento, carregadas de mensagens de ódio e preconceituosas, circulam pelas páginas das campanhas publicitárias por elas analisadas. Segundo as autoras, este fato leva a considerar que, mesmo sob um feminismo diluído em mensagens de auto-ajuda, há movimentos de resistência ao conteúdo divulgado.

Isso remete a algumas discussões levantadas por Banet-Weiser (2018), sobre um «feminismo popular», mais visível e acessível, propagado através de diferentes plataformas midiáticas. Para a autora, há um significado político importante em levar discussões feministas para um público maior; porém, muitas vezes, os discursos que são tornados mais visíveis são aqueles que se articulam a uma concepção normativa (como valorização da feminilidade, e um feminismo branco, cisgênero, de classe média, e heteronormativo). Estudos que propõem uma leitura 
crítica da mídia, a partir de um olhar feminista e anti-racista, ressaltam a importância de uma «política de visibilidade», como um processo de tornar visível categorias historicamente marginalizadas, buscando uma mudança social, no sentido de mostrar como diferentes práticas (por exemplo, de gênero e sexualidade) são valoradas e reconhecidas em termos sociais, políticos e culturais.

Porém, no contexto capitalista contemporâneo, embora as políticas de visibilidade continuem relevantes, há um destaque para uma «economia de visibilidade», onde o foco não é a justiça social e o objetivo passa a ser apenas produzir mais visibilidade (Banet-Weiser 2018). Plataformas digitais, constituídas por grandes corporações, inserem a lógica de mercado no processo de visibilidade, que passa a ser medido por números, «curtidas», «compartilhamentos», visando o lucro de seus investidores. Assim, uma vez que o grande objetivo da publicidade é mercadológico, são as «curtidas» e «descurtidas» que dão a medida de até onde alguns corpos fora dos padrões estéticos podem ir.

Nesse sentido, o feminismo que se destaca na TV, em filmes, propagandas e, sobretudo, nas redes sociais, muitas vezes termina em si mesmo, como se «ver» ou comprar «produtos feministas» fosse o suficiente para mudar as estruturas patriarcais. Assim, é preciso uma análise conjuntural do contexto capitalista e neoliberal que sustenta e valoriza alguns feminismos em detrimento de outros. Há, portanto, uma relação direta desse feminismo com o consumo, uma vez que os feminismos mais facilmente comercializáveis são aqueles colocados em evidência, em detrimento de vertentes, coletivos e ações que partam de uma crítica às estruturas patriarcais e aos modos de dominação e exploração contemporâneos, incluindo-se aqui os modos de produção e subjetivação neoliberais (Banet-Weiser 2018).

Ressaltamos que a escolha de tratar do femvertising não significa que a lógica mercadológica que coopta o feminismo seja restrita à publicidade, ou que seja a única maneira pela qual o capitalismo interpela os sujeitos. Antes disso, é uma lógica pautada em um sujeito econômico neoliberal (Banet-Weiser, Gill, Rottenberg 2019). Assim, esse feminismo, popularizado através das esferas digitais, precisa de ser entendido como constituído também por práticas e valores do neoliberalismo, produzindo sujeitos feministas que operam em uma lógica individualista e empreendedora, onde iniciativas pessoais e inovadoras são entendidas como práticas feministas (Rottenberg 2014).

Contudo, mesmo que a apropriação realizada pelos anúncios identificados como femvertising signifique uma possível pasteurização, vulgarização e mercantilização das lutas feministas, não se pode negar que ele traz elementos positivos: quebra de estereótipos, popularização do discurso feminista e abertura de novos espaços para performances feministas. Além disso, considerando o caráter relacional das mediações entre produtor e consumidor de conteúdo midiático, a mensagem publicitária, ainda que intencionalmente construída e endereçada a um grupo específico, quando apresentada ao público será apropriada de diferentes formas. Assim, diferentes mulheres fazem uso destes espaços, apostando em outras e 
novas mediações, em um embate contínuo, na contramão do interesse financeiro das marcas (Arndt e Miguel 2019).

\section{Considerações finais}

As reflexões aqui empreendidas apontam para a presença de uma dualidade com relação ao feminismo digital. Ao mesmo tempo em que o meio digital se apresenta como um espaço de militância e de visibilidade dos feminismos, ele é palco de disputas mercadológicas que se apropriam de motes feministas visando o consumo.

Nesse sentido, quando pensamos na formação de uma nova onda que se caracteriza, «não necessariamente por uma mudança de pautas», e sim pela relação com as mídias, estamos informando que se trata de um feminismo diretamente atravessado pela lógica de mercado. Para que não seja assim, é preciso pensar estratégias de uso desses espaços para além dos ambientes fornecidos por corporações. É preciso incluir um debate sobre o acesso à Internet, sobre a exclusão digital, sobre uma educação para as mídias. $\mathrm{O}$ feminismo precisa de se inserir no entre, na brecha, na disputa desses espaços, e não apenas como mais um produto destas plataformas. Essas brechas existem e já vem sendo ocupadas. São, por exemplo, as inúmeras marchas articuladas via redes sociais, as hashtags que denunciam e escancaram violências e desigualdades, os grupos fechados no Facebook que propiciam um espaço de desabafo e reflexão para as mulheres.

Em meio à crise sanitária, administrativa, humanitária e civilizatória que enfrenta a população brasileira, olhamos para a primeira década da quarta onda do feminismo no Brasil e perguntamos: quais os caminhos que nos trouxeram até aqui, que caminhos escolheremos trilhar daqui por diante? É certo que o caminho será repleto de obstáculos e desafios, mas é a potência desse caminho que preferimos salientar. E há muita potência no meio digital.

Especialmente nos últimos meses, devido à chegada da pandemia desencadeada pela COVID-19, tem-se acompanhado um sem número de publicações nas redes sociais - seja em perfis do Facebook, em contas e lives no Instagram e em vídeos no Youtube - abordando os mais diversos temas, relacionados, inclusive, ao impacto da pandemia na vida das mulheres. Diante de tal cenário, que tem exigido o isolamento social, o meio digital tem sido protagonista, mais do que nunca. Além de fonte de informação, as novas tecnologias têm proporcionado encontros que estão proibidos no «mundo real». Afeto, companhia, colo, aconchego, são encontrados através de vídeos, fotos, vídeo-chamadas e aplicativos que proporcionam encontros virtuais com familiares, amigos e colegas de trabalho.

Em meio a embates políticos, ataques conservadores, fortalecimento de preceitos neoliberais, cerceamento de direitos, as mulheres reunidas em torno de pautas feministas têm cumprido um papel central de resistência e de luta. Suas 
ações, sejam no meio digital ou nas ruas, conferem força e visibilidade a diferentes mulheres, diferentes pautas, diferentes feminismos. As mulheres do Brasil podem não ter conseguido impedir a eleição de um presidente misógino, mas puderam mostrar, por meio da articulação nas redes sociais, que aquilo que começa no meio virtual tem potencial de se transformar em uma grande onda de luta contra as injustiças e desigualdades.

\section{Referências bibliográficas}

Albu, Débora. 2017. «Ciberfeminismo no Brasil: construindo identidades dentro dos limites da rede.» Seminário Internacional Fazendo Gênero 11 E 13th Women's Worlds Congress. Florianópolis - SC.

Arndt, Gilmara Joanol, e Raquel de Barros Pinto Miguel. 2019. «Para todEs: reflexões acerca do femvertising». In Publicidade e Gênero: representações e práticas em questão, organizado por Milena Freire de Oliveira-Cruz, 171-193. Santa Maria: Facos-UFSM.

Babo, Isabel. 2017. «Redes e ativismo». In Net-ativismo: redes digitais e novas práticas de participação, organizado por Massimo Di Felice, Erick Roza e Eliete Pereira, 77-88. Campinas: Papirus Editora.

Banet-Weiser, Sarah. 2018. Empowered: Popular Feminism and Popular Misogyny. Durham, NC, USA: Duke University Press. DOI: http: / / doi.org/10.1215/9781478002772

Banet-Weiser, Sarah, Rosalind Gill e Catherine Rottember. 2019. «Postfeminism, popular feminism and neoliberal feminism? Sarah Banet-Weiser, Rosalind Gill and Catherine Rottemberg in conversation».Feminist Theory 21(1):3-24.DOI:10.1177/ 464700119842555

Brown, Wendy. 2003. «Neo-liberalism and the End of Liberal Democracy.» Theory E Event 7(1). DOI:10.1353/tae.2003.0020.

Crenshaw, Kimberle. 1989. «Demarginalizing the Intersection of Race and Sex: A Black Feminist Critique of Antidiscrimination Doctrine, Feminist Theory and Antiracist Politics.» University of Chicago Legal Forum Vol. 1989: Iss. 1, Article 8: 139-167.

Dias, Cristiane. 2018. Análise do discurso digital: sujeito, espaço, memória e arquivo. Campinas: Pontes.

Díaz-Benítez, María Elvira e Nathalia Gonçales. 2018. «Por dentro do ringue: gênero e sexualidade no embate da inclusão por direitos». Revista Ñanduty 6(8):156-180.

Fraser, Nancy. 2019. «Capitalismo, feminismo e astúcia da história». In Pensamento feminista: conceitos fundamentais, organizado por Heloísa Buarque de Hollanda. Rio de Janeiro: Bazar dos Tempos.

Gomes, Carla e Bila Sorj. 2014. «Corpo, geração e identidade: a Marcha das vadias no Brasil.» Sociedade e Estado 29(2): 433-447. DOI: https:/ / doi.org/10.1590/S0102-69922014000 200007

Hawkesworth, Mary. 2006. «A semiótica de um enterro prematuro: o feminismo em uma era pós-feminista». Estudos Feministas 14(3): 737-763. DOI: https: / / doi.org/10.1590/ S0104-026X2006000300010

Hollanda, Heloisa Buarque de. 2018. Explosão Feminista: arte, cultura, política e universidade. São Paulo: Companhia das Letras.

Oksala, Johanna. 2019. «O sujeito neoliberal do feminismo». In Neoliberalismo, Feminismos e Contracondutas: perspectivas foucaultianas, organizado por Margareth Rago e Mauricio Pelegrini, 115-138. São Paulo: Intermeios. 
Pedro, Joana Maria e Lemes, Luana. 2019. «A 'primavera das mulheres' nos impasses atuais da democracia no Brasil.» In Feminismos \& democracia, organizado por Joana Maria Pedro e Jair Zandoná, 67-86. Belo Horizonte: Fino Traço.

Perez, Olívia e Arlene Ricoldi. 2018. «A quarta onda do feminismo? Reflexões sobre movimentos feministas contemporâneos.» Anais do $42^{\circ}$ Encontro Anual da ANPOCS. Caxambu-MG.

Pinto, Céli Regina Jardim. 2003. Uma história do feminismo no Brasil. São Paulo: Fundação Perseu Abramo.

Prügl, Elisabeth. 2015. «Neoliberalising Feminism.» New Political Economy 20(4): 614-631.

Quintão, Graziela. 2017. «A nova direita cristã: alianças, estratégias e transfiguração do discurso religioso em torno do projeto de cura gay». Estudos de Sociologia 22(42): 53-71.

Rocha, Everardo. 2001. «A mulher, o corpo e o silêncio: a identidade feminina nos anúncios publicitários». Alceu: Revista de Comunicação, Cultura e Política 2(3): 15-39.

Rottenberg, Catherine. 2014. «The Rise of Neoliberal Feminism». Cultural Studies, 28:3, 418437. DOI: $10.1080 / 09502386.2013 .857361$

Safatle, Vladimir. 2015. O circuito dos afetos: corpos políticos, desamparo e o fim do indivíduo. Belo Horizonte: Autêntica.

Schmidt, Simone. 2004. «Como e por que somos feministas.» Revista Estudos Feministas (12): 17-22. DOI: http: / / dx.doi.org/10.1590/S0104-026X2004000300002

Silva, Ana Cláudia e Leandro Franklin Gorsdorf. 2020. «O direito à cidade entre os ecos do \# elenão: a cidade como obra a partir dos corpos na rua.» Revista Direito Práxis 11(1): 645-665. DOI: $10.1590 / 2179-8966 / 2020 / 48214$

Sombrio, Paula Biazeto Machado e Miguel, Raquel de Barros Pinto. Capítulo no prelo. «'Não se meta com os meus filhos': discutindo gênero e sexualidade na escola.» In Psicologia Escolar e Educacional: Processos educacionais e debates contemporâneos, organizado por Leandro C. Oltramari, Ligia R. C. Feitosa, e Marivete Gesser.

Wright, Erik Olin. 2019. Como ser anticapitalista no século XXI? Boitempo Editorial.

Raquel de Barros Pinto Miguel. Doutora em Ciências Humanas - UFSC. Pós-doutora pela Université Paris Diderot - Paris 7 e pela Université Paris 13 - Sorbonne Paris Cité. Docente do departamento de Psicologia da UFSC. Coordenadora do Núcleo de Estudos e Ações em Gênero, Educação, Mídia e Subjetividade (NUGEMS), pesquisadora vinculada ao Instituto de Estudos de Gênero (IEG/UFSC). Coordenadora do CEDOC - Centro de Documentação do IEG.

Endereço eletrónico: raquelbarros@hotmail.com

Djenifer Samantha Marx. Psicóloga formada pela Universidade Federal de Santa Catarina. Mestranda do Programa de Pós-Graduação em Psicologia da Universidade Federal de Santa Catarina, na área de concentração «Psicologia Social e Cultura» e na linha de pesquisa «Processos de subjetivação, gênero e diversidades». Pesquisadora vinculada ao Núcleo de Estudos e Ações em Gênero, Educação, Mídia e Subjetividade (NUGEMS - UFSC).

Endereço eletrónico: djeni.marx@hotmail.com 
Gilmara Joanol Arndt. Psicóloga. Mestranda do Programa de Pós-Graduação em Psicologia da Universidade Federal de Santa Catarina (PPGP / UFSC), na área de concentração «Psicologia Social e Cultura», sob a linha «Processos de subjetivação, gênero e diversidades». Pesquisadora vinculada ao Núcleo de Estudos e Ações em Gênero, Educação, Mídia e Subjetividade - NUGEMS.

Endereço eletrónico: gilmaraarndt@gmail.com

Artigo recebido em 9 de junho e aceite para publicação, após revisão, em novembro de 2020. 


\title{
PÓS-FEMINISMO, PÓS-RACIALISMO E PÓS-COLONIALISMO: A COBERTURA MEDIÁTICA DA CAMPANHA DE JOACINE KATAR MOREIRA
}

\author{
Rita Basílio de Simões* \\ (D) https: / / orcid.org/0000-0001-6356-6042 \\ Inês Amaral ** \\ (D) https: / / orcid.org/ 0000-0003-4929-4866
}

\section{Resumo}

As relações entre género, poder e política ecoam de forma profunda na representação mediática de mulheres no campo político, normalizando modelos de feminilidade e conceções da participação no espaço público. Partindo deste pressuposto e recorrendo a uma abordagem interseccional ancorada numa perspetiva feminista, este artigo recorre à análise temática crítica para examinar a cobertura mediática da campanha para as eleições legislativas portuguesas de 2019 de Joacine Katar Moreira. Identificamos os discursos ideológicos prevalecentes, relacionando-os com os conceitos de pós-feminismo, pós-racialismo e pós-colonialismo e problematizando as suas implicações para o acesso igualitário à tomada de decisão política e para a efetiva promoção da igualdade de género.

Palavras-chave: Media informativos, mulheres políticas, representação, pós-feminismo, Joacine Katar Moreira.

\section{Abstract \\ Post-feminism, post-racialism and post-colonialism: The media coverage of Joacine Katar Moreira's campaign \\ The relations between gender, power and politics resonate deeply in the media representation of women in the political field, normalizing models of femininity and conceptions of participation in the public sphere. Based on this assumption and using an intersectional approach anchored to a feminist perspective, this article draws on critical thematic analysis to examine the media coverage of the campaign for the 2019 Portuguese legislative elections by Joacine Katar Moreira. We identify the prevailing ideological discourses, relating them to the concepts of post-feminism, post-racialism and post- colonialism, and questioning their implications for equal access to political decision-making and for the effective promotion of gender equality.}

Keywords: News media, political women, representation, post-feminism, Joacine Katar Moreira.

Univ Coimbra, Faculdade de Letras (FLUC), 3000-370 Coimbra, Portugal; Instituto de Comunicação da NOVA (ICNOVA), 1069-061 Lisboa, Portugal.

Endereço postal: Faculdade de Letras, Largo da Porta Férrea, 3000-370 Coimbra, Portugal.

Endereço eletrónico: rbasilio@fl.uc.pt

** Univ Coimbra, Faculdade de Letras (FLUC), 3000-370 Coimbra, Portugal; Centro de Estudos de Comunicação e Sociedade (CECS), Universidade do Minho, 4710-057 Braga, Portugal.

Endereço postal: Faculdade de Letras, Largo da Porta Férrea, 3000-370 Coimbra, Portugal.

Endereço eletrónico: ines.amaral@uc.pt 


\begin{abstract}
Resumen
Postfeminismo, postracialismo y poscolonialismo: la cobertura mediática de la campaña de Joacine Katar Moreira

Las relaciones entre género, poder y política resuenan profundamente en la representación mediática de las mujeres en el campo político, normalizando modelos de feminidad y concepciones de participación en la esfera pública. Basado en esta suposición y utilizando un enfoque interseccional anclado a una perspectiva feminista, este artículo se basa en un análisis temático crítico para examinar la cobertura mediática de la campaña para las elecciones legislativas portuguesas de 2019 por Joacine Katar Moreira. Identificamos los discursos ideológicos prevalecientes, relacionándolos con los conceptos de posfeminismo, posracialismo y poscolonialismo y cuestionando sus implicaciones para la igualdad de acceso a la toma de decisiones políticas y para la promoción efectiva de la igualdad de género.
\end{abstract}

Palabras clave: medios informativos, mujeres políticas, representación, postfeminismo, Joacine Katar Moreira.

\title{
Introdução
}

Iniciada em 22 de setembro de 2019, a campanha eleitoral para a XIV Legislatura Portuguesa ficou marcada pela circunstância de fazer aflorar no espaço público, sob intenso mediatismo, a primeira mulher negra no papel de cabeça de lista de um partido político em Portugal. A luso-guineense historiadora de profissão e desconhecida do grande público Joacine Elysees Katar Tavares Moreira (JKM) liderou a candidatura pelo círculo eleitoral de Lisboa do partido de Esquerda LIVRE, granjeando uma representação mediática que reproduz muitas das tensões conhecidas da relação entre género, poder e política, sem deixar de configurar um caso de estudo de representação política feminina singular.

A investigação da representação mediática de atores políticos tem mostrado como as mulheres tendem a figurar nos media informativos como um fenómeno novo e desviante relativamente às normas de género. Permanentemente julgadas perante o padrão normativo masculino, as mulheres candidatas, membros ou líderes de câmaras parlamentares ou executivos de Governo são, com frequência, reificadas como estranhas num campo globalmente dominado por homens, como mães e cuidadoras que estão fora do seu lugar e como mais cooperantes do que os atores políticos masculinos (Campus 2013). Todavia, a excecionalidade da figura de JKM, que acabou eleita deputada ao parlamento português, traduzida na cor da sua pele, na sua gaguez pronunciada, no seu ativismo feminista declarado, contaminou a cobertura mediática da figura política chave de um jovem partido fundado em 2013, apostado em conquistar representação parlamentar.

JKM configura, pois, um caso exemplar do escrutínio mediático cerrado de mulheres políticas, que está nos antípodas das dinâmicas clássicas de sub-representação. A investigação feminista dos media mostra que, originalmente, os meios de comunicação subestimam e menosprezam as candidatas políticas e mulheres 
parlamentares, sub-representando-as comparativamente com os políticos homens, negando-lhes títulos honoríficos, identificando-as pelo primeiro nome, por relações familiares com sujeitos masculinos ou usando descrições de género pouco lisonjeiras, sinalizando ao público que a política é, em última análise, «um jogo de homens» (Ross 2009). Nos últimos anos, outras formas de atuação mediática têm sido documentadas, nomeadamente a atenção exacerbada às figuras políticas femininas e às intersecções identitárias que personificam (Joshi, Hailu e Reising 2019), sujeitando esses atores sociais a uma "supervigilância» e hipervisibilidade na cobertura mediática (Ward 2017, 47).

Quando os media ignoram a relevância das identidades intersectoriais, tornam-nas invisíveis e esse efeito pode ser tão problemático para a promoção da igualdade de género quanto a sub-representação de mulheres relativamente aos homens (Gill 2007; Hayes e Lawless 2016; Haraldsson e Wängnerud 2019). Por outro lado, quando as identidades interseccionais são acentuadas, tal não conduz necessariamente a uma representação pública justa e não estereotipada e a uma afirmação dos direitos políticos das mulheres.

Partindo do pressuposto de que é também pelas representações mediáticas que o poder social flui (Simões 2017; Amaral et al. 2019), neste artigo, analisamos o modo como os principais media informativos portugueses representaram a candidata do LIVRE JKM durante o período de campanha eleitoral das últimas eleições legislativas portuguesas. A partir de uma abordagem interseccional ancorada numa perspetiva feminista, e recorrendo à análise temática crítica, identificamos os padrões de representação e os discursos ideológicos prevalecentes na cobertura mediática da candidata e problematizamos as suas implicações para o acesso igualitário à tomada de decisão política e para a real e efetiva promoção da igualdade de género na sociedade em geral.

\section{Media, género e política}

É consabido que persistem profundos desequilíbrios relativamente ao lugar e ao papel desempenhado por homens e mulheres nos media e na paisagem comunicacional em geral. Uma das preocupações que têm alimentado a investigação feminista em comunicação nas últimas décadas é justamente o modo como os media representam as mulheres políticas (Ross 2002), ainda que o número de mulheres na cena política tenha aumentado substancialmente um pouco por todo o mundo ocidental.

Globalmente, cinco grandes tendências têm sido identificadas pela investigação feminista das representações mediáticas de mulheres candidatas políticas no Ocidente. Uma dessas tendências é a da sua sub-representação. Independentemente do contexto geográfico, na paisagem mediática, as figuras políticas femininas tendem a ser significativamente menos visíveis do que os homens (Carlin e 
Winfrey 2009; Ross 2009; Martins 2015). Indissociável da histórica e global ausência de plenos direitos políticos, este padrão interliga-se com a difícil integração das mulheres no campo, não obstante a introdução, um pouco por todo o mundo, desde a década de 1990, de quotas eleitorais de género (Monteiro 2011). A sub-representação das mulheres na política e a persistência de padrões de comportamentos desfavoráveis à integração das preocupações das mulheres nos complexos parlamentários explicarão, assim, em parte, a razão pela qual, nas performances mediáticas, as mulheres continuam a figurar como estando fora do lugar (Campus 2013).

Claramente, estas são performances que reforçam o mesmo pensamento binário homem/mulher, homem no espaço público/mulher no espaço privado que estrutura outro dos padrões de representação de mulheres políticas, que se traduz não na invisibilidade, mas na visibilidade problemática, outra das faces do fenómeno que Gay Tuchman (1978) designou de aniquilação simbólica feminina. Com efeito, a investigação no campo documenta a tendência para uma cobertura centrada em assuntos relativamente triviais, tais como a aparência física, a forma de apresentação, o estado civil, a trajetória de infância e o estilo de vida e família, em lugar de preocupada com as ideias e propostas políticas (Braden 1996; Carlin e Winfrey 2009). Numa cobertura desta natureza, as mulheres políticas experimentam um intenso escrutínio das suas características pessoais, que pode contribuir para a sua objetificação (Wasburn e Wasburn 2011; Ritchie 2013), incluindo como objetos sexuais (Carlin e Winfrey 2009), e afetar a sua carreira política (Heflick e Goldenberg 2009; Haraldsson e Wängnerud 2019).

As performances mediáticas tendem, igualmente, a veicular uma cobertura mais negativa das mulheres comparativamente aos homens, com frequência questionando as suas características pessoais, a sua experiência e o conhecimento para levar a cabo uma liderança política eficaz (Devitt 1999; Carlin e Winfrey 2009). Ainda que alguns estudos mostrem que o impacto dos discursos estereotipados afeta de forma menos positiva os homens do que as mulheres (Fridkin, Kenney e Woodall 2009), a cobertura centrada nas particularidades individuais contribui para desqualificar as suas qualidades como sujeitos políticos, particularmente em áreas chave da vida social, tais como a economia e a segurança nacional (Carroll e Fox 2006; Devitt 1999).

Outra tendência da cobertura mediática é, justamente, a associação reiterada do perfil político feminino a questões consideradas «de mulheres», tais como a educação, a conciliação da vida profissional e familiar, a interrupção voluntária da gravidez, esvaziando, por vezes, a sua autoridade em matéria de questões ditas «masculinas» (Devitt 1999; Carroll e Fox 2006), mas contrariando a clássica noção de que as mulheres nem sempre parecem representar as mulheres quando adquirem poder político (Childs e Mona 2008).

Um quinto padrão da cobertura mediática de mulheres políticas mostra uma outra forma de atuação dos media informativos que, em lugar de ignorarem ou 
exacerbarem os atores políticos femininos como desviantes e fora do lugar, os normalizam no espaço dos órgãos decisórios. Embora reconheçam que as mulheres sempre enfrentaram experiências marcadamente sexistas, estes estudos sustentam que o cenário político mudou, que as mulheres deixaram de configurar novidades eleitorais, o que veio a repercutir-se na emergência de um leque mais diversificado de representações mediáticas, «normalizando» as mulheres na política (Hayes e Lawless 2016). Quando os media realçam, por exemplo, os contributos positivos de mulheres políticas na intervenção pública no domínio da igualdade de género, estão notoriamente a representar como virtuosas as mulheres que atuam no campo político (Joshi, Hailu e Reising 2019).

De facto, o maior acesso das mulheres à tomada de decisão pública, graças designadamente a opções, como a que em Portugal se tomou, de instituir limiares mínimos de paridade aplicáveis às listas de candidaturas apresentadas à Assembleia da República, ao Parlamento Europeu e aos órgãos eletivos das autarquias locais, favorecerá uma menor atratividade por uma cobertura centrada nas mulheres políticas por serem mulheres. Alguma investigação sugere mesmo que as mulheres políticas, não sendo já uma exceção, podem receber uma cobertura simpática e favorável, ao serem consideradas virtuosas em dimensões como a compaixão e a honestidade (Hayes e Lawless 2016) e mais motivadas ou capazes de promover a igualdade de género e a representação de grupos marginalizados (Verge e Pastor 2018).

Além das teses da novidade, da desqualificação e da normalização, a investigação feminista mais recente tem também destacado a tendência dos media para a identificação das identidades interseccionais (Cho, Crenshaw e McCall 2013). A partir da perspetiva da interseccionalidade, estes estudos têm sublinhado como as particularidades distintivas dos sujeitos políticos são iluminadas ou obscurecidas pelos media, com efeitos significativos na representação pública destes sujeitos (Ward 2017; Joshi, Hailu e Reising 2019). Cunhado por Crenshaw (1991), o conceito de interseccionalidade encerra uma teoria multidimensional que reconhece que as identidades sociais são dinâmicas, uma vez que se interseccionam em várias dimensões, social e culturalmente construídas, que desencadeiam processos de opressão, discriminação e desigualdades (Nogueira 2011).

Em última instância, o conceito de interseccionalidade questiona as interrelações de poder nas identidades sociais e estruturas (Crenshaw 1991) e favorece uma compreensão dos grupos identitários, ao permitir analisar as representações sociais e os processos de opressão que são moldados pelo género, raça, classe e particularidades pessoais distintivas associadas a desordens ou defeitos, a exemplo da gaguez. O plano dos valores e das ideologias é, por conseguinte, instrumental para pensar a construção mediática das identidades interseccionais das mulheres e a sua relação com o género, o poder e a política. 


\section{Pós-feminismo, pós-colonialismo, pós-racialismo}

O feminismo tornou-se mainstream (Fraser 2013) nos discursos públicos de empoderamento das mulheres que procuram criar uma ideia de um feminismo contemporâneo e popular (Banet-Weiser 2018a), que se traduz numa evidente ligação ao neoliberalismo (McRobbie 2004). Enquanto manifestação de feminismo popular, o pós-feminismo circula nos media, na Internet e na publicidade numa perspetiva mercantilizada, intensificando a ideia de um feminismo «cool», jovem e de self-empowerment (Banet-Weiser 2018a). Ancorado numa cultura neoliberal (Gill 2007), um feminismo individual e dirigido a mulheres brancas privilegiadas adquiriu particular popularidade nos media sociais e nas campanhas publicitárias (BanetWeiser e Portwood-Stacer 2017). Foi a este fenómeno suportado pelo chavão empreendedor do neoliberalismo que Zeisler (2016) apelidou de femvertising.

É no contexto desta subjetividade feminista que reside o pós-feminismo. Enquanto ideologia neoliberal, incorpora um foco individualista e enfatiza os discursos feministas liberais de independência, escolha e ação (Banet-Weiser 2018b). Assumindo uma disrupção com o questionamento das desigualdades estruturantes de género, a cultura neoliberal reifica os corpos femininos a performances hipersexualizadas (Álvares 2017) e normativas do que deve ser uma mulher (Amaral, Santos e Brites 2020). O constrangimento da escolha (McRobbie 2009) traduz-se também nas «fronteiras da feminilidade» (Álvares 2017, 103), o que reforça relações de poder ancoradas numa normatividade instrumentalizada pelo neoliberalismo na cultura popular (Banet-Weiser e Portwood-Stacer 2017; BanetWeiser 2018b) esvaziando os programas feministas da sua essência política (Vavrus 2002; Gill 2007). Este «commodity feminism» (Goldman 1992) alia o feminismo ao capitalismo da sociedade de consumo, criando a normalização de novas dinâmicas de sexismo e misoginia (Gill 2016; Simões e Silveirinha 2019). Dos usos simbólicos de género e da feminilidade (McRobbie 2009), o pós-feminismo apropria as velhas reivindicações dos movimentos feministas como forma de legitimação moral, visibilizando e despolitizando o feminismo (Vavrus 2002) e mercantilizando-o como um produto de cultura popular (Banet-Weiser 2018a).

A normatividade tem sido predominante nos discursos mediáticos e mediatizados, que incorporam também um espaço discursivo que afirma um feminismo «moderado» que normaliza as conquistas das mulheres. Enquadrada na ideologia pós-feminista, a «domesticação» é defendida por Dean (2010) como uma forma de incorporação do feminismo «moderado» nos media, por oposição ao feminismo «radical», que também reproduz mitos e estereótipos do sistema patriarcal.

A esta luz, as mulheres na política figuram, com frequência, representadas como um sujeito pós-feminista. Além de reificar uma ligação intrínseca entre a esfera pública e privada (Vavrus 2002, 131), o sujeito feminino pós-feminista também naturaliza a feminilidade branca com privilégios de classe, a marca distintiva das mulheres visíveis na política nacional e local (Carlin e Winfrey 2009). E é 
justamente por tornarem os elementos raciais e de classe invisíveis que estas dinâmicas comunicativas se articulam com as ideias do pós-racialismo, uma teoria que ganhou força com a eleição de Barack Obama para a presidência norte-americana, em 2008, num contexto em que o pós-colonialismo oblitera os contextos históricos e culturais das mulheres norte-americanas.

Os contextos sociais, históricos e culturais dos estudos pós-coloniais sobrepõem-se, frequentemente, a questões de género, raça e classe (Tyagi 2014). O pós-colonialismo celebra o anticolonialismo como ato de resistência, mas silencia as hierarquias de género em espaços racializados (Parashar 2016). A tensão entre os estudos pós-coloniais e a teoria feminista pós-colonial assenta na sub-representação das mulheres colonizadas. A teoria feminista pós-colonial mostra que a mulher colonizada sofre uma «dupla colonização» (Peterson e Rutherford 1986), na medida em que experimenta a opressão colonialista e patriarcal (Tyagi 2014).

A leitura das identidades subalternas a partir da epistemologia da alteridade resgata as experiências inviabilizadas das mulheres que foram reconstruídas como o «Outro» no pensamento moderno ocidental (Spivak 1989). A partir desta leitura, as mulheres colonizadas libertam-se das narrativas que as colocam como o «Outro» e são representadas no seu contexto histórico e cultural. O pensamento de Spivak (1989) assenta no questionamento dos instrumentos de poder e nas possibilidades de agência do sujeito subalterno no espaço pós-colonial genderizado. Criticando o silenciamento dos vários feminismos sobre este «Outro», Spivak (2010) aborda os «feminismos subalternos» por oposição a um feminismo universalista, eurocêntrico, ocidental e branco. As dinâmicas pós-coloniais alinham com o pós-feminismo e o pós-racialismo, reificando a opressão.

Os discursos do pós-racialismo assumem a retórica de uma espécie de «pós-direitos civis» (Kennedy 2017), relativizando a experiência do racismo (Lentin 2011). As ideias pós-racialistas assentam na perspetiva conservadora, numa interpretação livre da ciência, de que a raça não existe (Kennedy 2017), logo, o racismo não existe. As narrativas pós-raciais despolitizaram a questão racial e criaram um imaginário ancorado nos media e no entretenimento da indústria de Hollywood (Francisco 2017).

O pós-feminismo e o pós-racialismo assentam numa retórica neoliberal, projetando a ideia de que a consciência de género e raça são escolhas (Vavrus 2002; Kennedy 2017). Estes discursos hegemónicos ocultam estruturas de poder que perpetuam sistemas de opressão no que concerne a género, raça e classe. Nos media ecoam apropriações de campanhas feministas como «revolução», «poder» e «sobrevivência» numa reconfiguração do ativismo em estruturas corporativas que assumem a raça como o elemento que induz a ideia de diversidade e integração, aportando numa apropriação da luta antirracista. O pós-racialismo e o pós-feminismo popularizados nos media e na Internet, utilizando figuras como Oprah Winfrey e Hillary Clinton, perpetuam-se nas invisibilidades e sub-representações das mulheres fora do «padrão» normativo, discursos de alteridade e formas dissimuladas de discriminação. 


\section{A cobertura da campanha de JKM}

Reconhecendo a importância de produzir evidências empíricas quantitativas e qualitativas que permitam conhecer as performances mediáticas, a fim de apoiar a formação de consensos acerca da necessidade de intervenção nas políticas de comunicação dirigidas aos media, este artigo analisa a representação de JKM nos media mainstream portugueses. Tomando como horizonte teórico uma perspetiva feminista ancorada numa abordagem interseccional, analisamos a representação da candidata do LIVRE na produção informativa publicada nas plataformas online de quatro títulos da imprensa generalista portuguesa e de um jornal nativo digital durante a campanha para as eleições legislativas portuguesas de 2019, que decorreu de 22 de setembro e 4 de outubro, período chave do papel da mediação no debate de questões de interesse público e, ao mesmo tempo, da construção da imagem das figuras políticas.

Tradicionalmente, a análise da cobertura noticiosa da esfera política centra-se nos períodos de campanha eleitoral, tendência que pode explicar-se pelo elevado interesse pelo potencial impacto dos media junto do eleitorado. Com raízes no trabalho pioneiro de Lazarsfeld, nos Estados Unidos (Lazarsfeld et al. 1944), os estudos do noticiário político têm permitido uma compreensão mais profunda das relações que podem tecer-se entre o campo dos media e o campo da política e, em especial, da visibilidade pública das figuras políticas. A investigação empírica que tem procurado analisar diferentes momentos do ciclo eleitoral tem, além disso, distinguido as especificidades próprias dos períodos de campanha, entre elas o menor grau de personalização de atores políticos, em virtude de as performances mediáticas tenderem a centrar-se menos nos indivíduos do que nos partidos políticos que representam (Van Aelst e De Swert 2009; Vliegenthart, Boomgaarden e Boumans 2011). Em linha com estes estudos, privilegiámos uma análise do período de campanha eleitoral.

Três questões de investigação guiaram a análise. Concretamente: (1) Quais os principais padrões de representação mediática? (2) Como é que os padrões de representação predominantes se relacionam com as construções socioculturais de género, raça e classe e com o contexto sociocultural e ideológico mais amplo? (3) Quais os efeitos da cobertura mediática na campanha de JKM? Para responder a estas questões recorremos à análise temática crítica.

\section{Estratégia metodológica}

A análise temática tem sido descrita como uma abordagem descritiva qualitativa independente que oferece um método para «identificar, analisar e relatar padrões (temas)» nos dados em análise (Braun e Clarke 2006, 79). Neste artigo, lançámos mão de uma análise temática a partir de uma abordagem qualitativa 
crítica (Lawless e Chen 2019), recorrendo ao software de análise qualitativa MAXQDA. A análise temática crítica permite-nos examinar as inter-relações entre os discursos nos textos - no nosso caso, nos textos dos media informativos -, as práticas sociais, as relações de poder e as ideologias (Chen e Lawless 2016).

Relativamente ao objeto, dirigimos a atenção para a imprensa no atual ecossistema mediático. Partindo da consideração do papel nuclear que a imprensa sempre desempenhou na vida pública, estabelecendo, na proposta original de Lippmann (1922), «mapas conceptuais do mundo»e, já no quadro dos estudos do agenda-setting, reconduzíveis originalmente ao trabalho de McCombs e Shaw (1972), «fixando a agenda» de públicos e decisores políticos e dos outros media, centrámo-nos em cinco jornais. Trata-se de cinco meios de comunicação social com importantes índices de circulação em Portugal, que ilustram diferentes tendências editoriais e que representam bem o alcance do espectro político: os jornais diários Correio da Manhã, Diário de Notícias e Público, o semanário Expresso e o nativo digital Observador. Constituímos um corpus de análise recolhido das edições online dos quatro legacy media e do jornal digital durante as duas semanas de campanha eleitoral com peças que incidem diretamente sobre a candidata JKM. Reunimos 23 peças informativas, que agrupámos levando em conta o jornal de proveniência e o género jornalístico utilizado na sua construção, tal como mostra a Tabela 1.

Tabela 1.

Cobertura da campanha de JKM por meio de comunicação

\begin{tabular}{|c|c|c|c|}
\hline \multirow{2}{*}{ Jornal } & \multicolumn{3}{|c|}{$\mathbf{N}=\mathbf{2 3}$} \\
\hline & Notícia & Perfil & Reportagem \\
\hline Público & 1 & 1 & 0 \\
\hline Observador & 3 & 0 & 1 \\
\hline Expresso & 10 & 0 & 0 \\
\hline Diário de Notícias & 2 & 0 & 0 \\
\hline Correio da Manhã & 4 & 0 & 1 \\
\hline
\end{tabular}

Fonte: Elaboração própria

Recorrendo à análise temática crítica, e utilizando as ferramentas do software MAXQDA, procurámos observar os padrões discursivos dos textos informativos e as ideologias, posições de poder ou hierarquias que esses padrões mobilizam. O processo analítico desdobrou-se em duas fases, seguindo a proposta de Brandi Lawless e Yea-Wen Chen (2019). Primeiro, a partir de um processo de codificação aberta (Owen 1984), identificámos padrões textuais: repetições de palavras e de frases, recorrências de sentidos idênticos criados por palavras diferentes e elemen- 
tos discursivos realçados. Este processo permitiu-nos codificar os temas frequentes, proeminentes e vigorosos no corpus de análise. Os padrões identificados foram, numa segunda etapa, interligados com o contexto ideológico mais amplo e agrupados em macrotemas. O procedimento de definição destes macrotemas levou em conta, portanto, os elementos textuais observáveis, mas também os elementos sistematicamente mitigados ou invisíveis, que são tão ou mais relevantes para as práticas discursivas. Deste modo, interligámos os padrões textuais com a influência dos discursos sociais dominantes (Chen e Lawless 2018). As autoras coparticiparam ativamente na construção dos temas e macrotemas.

A Figura 1 dá conta do resultado final deste exercício. Perpassam pelo corpus sete temas principais, que articulámos em dois macrotemas nucleares, que aglutinam o essencial da normatividade subjacente à cobertura mediática de JKM.

\section{Figura 1.}

Temas e macrotemas da cobertura mediática de JKM durante a campanha eleitoral para as eleições legislativas portuguesas de 2019

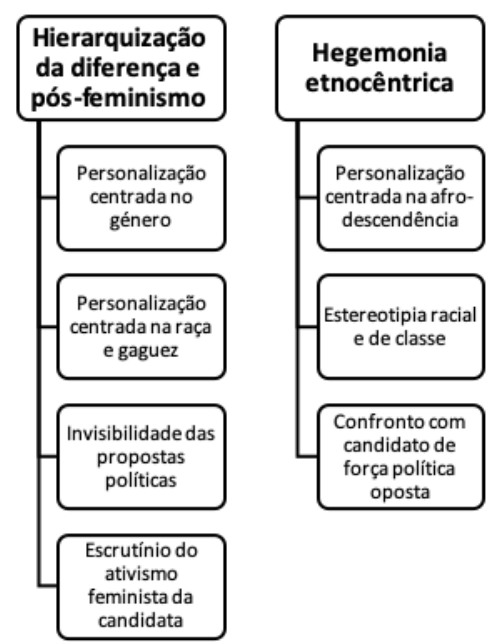

Fonte: Elaboração própria

\section{Análise e discussão de resultados}

«Hierarquização da diferença e pós-feminismo» é o macro tema com maior expressão no corpus de análise e que está intimamente relacionado com a excecionalidade dos atributos de JKM, que lhe outorga um valor-notícia, isto é, um interesse como matéria-prima suscetível de ser transformada em notícia (Wolf, 1987) muitíssimo elevado. 
Uma ativista negra a caminho do Parlamento? (Público, 4-10-2019)

O título interrogativo publicado pelo jornal Público no final da campanha ilustra bem como raça e género se articulam no discurso público, justificando uma cobertura orientada para a novidade da situação. Uma novidade deveras apetecível para os media mainstream. A exacerbação destas categorias - mulher e negra parece à superfície posicionar a candidata num lugar de desafio e de resistência dupla aos padrões do espaço político, considerado eminentemente masculino e branco. Contudo, tal como a investigação feminista também tem mostrado, a cobertura de excecionalidade, da novidade, tende a reificar o padrão.

Por outro lado, a visibilização do «Outro» por oposição aos padrões normativos dominantes não significa necessariamente uma dinâmica discursiva emancipadora, particularmente quando assenta, como é o caso, no efeito de "personalização» típico da política contemporânea, em que os atores se tornaram mais importantes do que as identidades coletivas dos partidos que representam (McAllister 2007). Contudo, a personalização pode ser altamente problemática. Com efeito, o foco reiterado na sua gaguez, bem como o questionamento persistente do modo como pode afetar a sua atuação política, configura menos uma força de inclusão do que de fomento do escrutínio das competências da candidata.

Na verdade, várias campanhas de desinformação e de difamação online dirigidas a JKM foram gizadas recorrendo justamente à exploração das suas características pessoais. O escrutínio da sua integridade como sujeito político começou desde logo a propósito do questionamento, veiculado nos media informativos, da genuinidade da sua gaguez. O que a limitada investigação da cobertura mediática da deficiência tem realçado é a existência de diferentes modelos de representação problemática, entre eles o modelo de patologia social (Clogston apud Haller 1993), à luz do qual as pessoas portadoras de deficiência são desfavorecidas e carecem do apoio do Estado, um apoio que é menos um direito do que uma dádiva. Outros modelos, a exemplo do modelo de consumo (Haller 1993), que destaca as suas qualidades como nicho de mercado inexplorado, não configuram necessariamente uma representação emancipadora. Neste caso, a gaguez de JKM aparece publicamente representada como falsa ou exagerada para granjear mediatismo e votos.

Depois de a gaguez ter ocupado parte do discurso sobre a candidata, surgiram nos últimos dias acusações de que Joacine não seria gaga, mas estaria a usar o facto como arma de campanha. (Expresso, 4-10-2019)

Bem se compreende que, perante um cenário dominado pela personalização baseada no género, raça e gaguez, as propostas políticas de JKM sejam absolutamente periféricas, além do que esta personalização ignora o papel de académica. JKM emerge no espaço público não como uma intelectual, não como historiadora ou especialista, mas, sim, como ativista feminista e dos direitos humanos. E esse 
ativismo, quando visível, também é sujeito a escrutínio, ou por ser considerado limitado ou extemporâneo:

A campanha da Joacine e do Livre tem insistido muito nos direitos das minorias e das mulheres que não são assim tão minoria - antes pelo contrário. (Observador , 2-10-2019)

Se olharmos para este tipo de discursos como exemplos de enunciados que mostram como foram supostamente resolvidas as reivindicações feministas «do passado» e garantidas as condições de igualdade, podemos interpretá-los como discursos construídos a partir de uma retórica neoliberal pós-feminista (Gill 2007), que não apenas desqualificam a agenda da candidata, como também a desqualificam a si.

Relativamente ao segundo conjunto de temas, «Hegemonia etnocêntrica», um primeiro aspeto que deve realçar-se é que, na cobertura mediática, JKM não é somente mulher, negra e gaga: é afrodescendente, condição que é sempre exaustivamente explorada, colocando em evidência e hiper-visibilizando a sua origem africana:

Apresentar como cabeça de lista por Lisboa uma mulher negra, afrodescendente e gaga é, assume Joacine Katar Moreira, «um incentivo para que qualquer indivíduo sinta que está habilitado a participar politicamente.» (Expresso, 24-9-2019)

A visibilidade conseguida é um êxito notável para Joacine, de 37 anos, negra nascida na Guiné-Bissau, a viver em Portugal desde os oito. (Correio da Manhã, 25-9-2019)

Este padrão discursivo centrado na personalização da sua afrodescendência pode ser visto como uma forma de reificar relações de hegemonia etnocêntrica e, em última instância, de uma ideia de colonialidade acomodada na sinalização da excecionalidade. Trata-se, pois, igualmente, de uma força cultural e ideológica que, pelo discurso, (re)produz e propaga ideologias dominantes (Hall 1997).

O recurso, ainda que com menos frequência, à estereotipia racial, que repousa no negro pobre, oriundo de bairros periféricos, a quem é oferecida uma oportunidade de ouro de derrubar barreiras, é uma outra forma de normalizar a condição minoritária e desfavorecida da população afrodescendente:

O historiador, eurodeputado entre 2009 e 2014 [Rui Tavares], vê em Joacine um exemplo de «genuinidade» e de como «é possível as pessoas comuns fazerem parte da política.» (Expresso, 28-9-2019)

De realçar também que, tal como sucede no excerto acima indicado, JKM é, com frequência, Joacine, diferentemente de Rui Tavares, fundador do partido LIVRE, que é nomeado de forma formal e identificado pela sua especialidade académica. 
Um outro tema visível na cobertura mediática da candidata JKM que se articula com uma força hegemónica etnocêntrica é o seu posicionamento em confronto sistemático com o candidato de uma força política oposta, André Ventura, do partido nacionalista CHEGA!

A candidata do Livre, comparando com o Presidente do Brasil, considerou que «Bolsonaro é um exemplo muito semelhante ao do André Ventura aqui.» (Correio da Manhã, 4-10-2019)

Este confronto da mulher afrodescendente de Esquerda com o português branco de Direita, instigado não raro pelo modo como as entrevistas jornalísticas são conduzidas, é expectável. É expectável, porque o confronto político, a altercação, a dicotomia entre extremos, são apetecíveis do ponto de vista mediático. Podemos, por outro lado, entender este padrão discursivo como um reflexo da campanha da candidata, com o objetivo de desviar a atenção da sua experiência política limitada, tal como foi sugerido relativamente à cobertura de algumas mulheres políticas, a exemplo de Sarah Palin (Wasburn e Wasburn 2011). Mas o recurso reiterado a esta fórmula é problemático e tem implicações na relação entre género, poder e política e, de modo mais amplo, na igualdade de género em geral.

\section{Conclusão}

A análise da cobertura mediática da candidata às eleições legislativas JKM mostra, à superfície, uma construção que contraria a invisibilidade das mulheres políticas nos media, posicionando-a num lugar de desafio e de resistência aos padrões normativos do espaço político, tradicionalmente masculino e branco. Contudo, a personalização reiterada e a hipervisibilidade do seu perfil singular traduzem-se numa «supervigilância» (Ward 2017) que, não tendo afetado de forma negativa os resultados eleitorais, se repercutiram, claramente, na imagem e carreira política de JKM e, sugerimos, no próprio imaginário da condição feminina no espaço público e político.

A cobertura dos primeiros meses de atividade parlamentar da deputada fez emergir no espaço público uma torrente de outros conflitos, nomeadamente com o também recém-eleito deputado André Ventura e com o seu próprio partido. JKM acusou o LIVRE de ter usado a sua condição de mulher negra para obter subvenções. ${ }^{1}$

«Joacine: 'Não podem exigir que deixe de gaguejar de uma hora para outra'», Jornal de Notícias online, 5-11-2020, URL: https:/ / www.jn.pt/nacional/joacine-nao-podem-exigir-que-deixe-de-gaguejar-de-uma-hora-para-outra-11482574.html; «Assembleia do Livre retira confiança política a Joacine Katar Moreira», Correio da Manhã online, 31-1-2020, URL: https:/ / www.cmjornal.pt/poli tica/ detalhe/ assembleia-do-livre-retira-confianca-a-joacine-katar-moreira; «André Ventura 'propõe' que Joacine 'seja devolvida ao seu país de origem'. Livre queixa-se de racismo,» Observador, 28-1- 
O partido retirou a confiança política à parlamentar que, a 3 de fevereiro de 2020, adquiriu no Parlamento o estatuto de deputada não inscrita. ${ }^{2}$

Por outro lado, é expectável que a cobertura estereotipada de novidade que documentámos, ainda que possa funcionar como uma mola propulsora para desviar a atenção de um perfil com experiência política limitada, eventualmente usado de forma instrumental pela candidata e/ou pelo seu partido, não favorece a normalização das mulheres no campo político e nas diferentes esferas de poder decisório.

Paralelamente, os media mainstream que examinámos reproduziram uma sensibilidade pós-feminista do mundo e reificaram uma hegemonia etnocêntrica, que mergulha as suas raízes num passado recente pouco discutido, porém disseminado nas práticas discursivas e culturais.

Considerando o alcance limitado do estudo que conduzimos e a visibilidade problemática da agora deputada JKM, sugerimos que, a partir igualmente de uma abordagem feminista qualitativa, estudos futuros analisem a cobertura da atividade parlamentar de mulheres políticas portuguesas, incidindo sobre diferentes tipos de meios de comunicação e levando em conta a importância da articulação das suas qualidades identitárias, desde logo de género, raça e classe, e os ambientes políticos e mediáticos em que se movem.

\section{Referências bibliográficas}

Álvares, Cláudia. 2017. «Pós-feminismo, misoginia online e a despolitização do privado.» Media \& Jornalismo 17(30): 99-110.

Amaral, Inês et al. 2019. «(In)visibilities of Men and Aging in the Media: Discourses from Germany and Portugal». Lecture Notes in Computer Science vol. 11593: 20-32. DOI: https: / / doi.org/10.1007 / 978-3-030-22015-0_2

Amaral, Inês, Sofia José Santos e Maria José Brites. 2020. «Mapping Intergenerational Masculinities on Instagram». Lecture Notes in Computer Science vol. 12209: 3-16. DOI: https: / / doi.org/10.1007 /978-3-030-50232-4_1

Banet-Weiser, Sarah. 2018a. Empowered: Popular Feminism and Popular Misogyny in an Economy of Visibility. Durham, NC: Duke University Press.

Banet-Weiser, Sarah. 2018b. «Postfeminism and Popular Feminism.» Feminist Media Histories 4(2): 152-156. DOI: https:/ / doi.org/10.1525/ fmh.2018.4.2.152

Banet-Weiser, Sarah e Laura Portwood-Stacer. 2017. «The traffic in feminism: An introduction to the commentary and criticism on popular feminism.» Feminist Media Studies 17(5): 884-888. DOI: https:/ / doi.org/10.1080/14680777.2017.1350517

-2020, URL: https: / / observador.pt/2020/01/28/andre-ventura-propoe-que-joacine-seja-devolvidaao-seu-pais-de-origem-livre-queixa-se-de-racismo/.

«Joacine deixa de representar o Livre e passa a deputada não inscrita a partir de hoje,» Público online, 3-2-2020, https:/ / www.publico.pt/2020/02/03/politica/noticia/joacine-deixa-representar-livre-passa-deputada-naoinscrita-partir-hoje-1902643 
Braden, Maria. 1996. Women Politicians and the Media. Lexington, KY: University Press of Kentucky.

Braun, Virginia e Victoria Clarke. 2006. «Using thematic analysis in psychology.» Qualitative Research in Psychology 3(2): 77-101. DOI: https:/ / doi.org/10.1191/1478088706qp063oa

Campus, Donatella. 2013. Women Political Leaders and the Media. Basingstoke: Palgrave Macmillan.

Carlin, Diana B. e Kelly L. Winfrey. 2009. «Have you come a long way, baby? Hillary Clinton, Sarah Palin, and Sexism in 2008 Campaign Coverage.» Communication Studies 60(4): 326-343. DOI: https: / / doi.org/10.1080/10510970903109904

Carroll, Susan J. e Richard L. Fox 2006. Gender and Elections: Shaping the Future of American Politics. Cambridge: Cambridge University Press.

Chen, Yea-Wen e Brandi Lawless. 2018. «'Oh my god! You have become so Americanized': Paradoxes of adaptation and strategic ambiguity among female immigrant faculty.» Journal of International and Intercultural Communication 11(1): 1-20. DOI: https:/ / doi. org/10.1080/17513057.2017.1385825

Chen, Yea-Wen e Brandi Lawless. 2016. «Immigrant Women Negotiating Shifting Meanings of Work and Confronting Micro-aggressions with/in the Ivory Tower.» In Immigrant Workers and Meanings of Work: Communicating Life and Career Transitions, organizado por Suchitrae Shenoy-Packer e Elena Gabor, 99-111. New York: Peter Lang.

Childs, Sarah e Lena Krook Mona. 2008. «Critical mass theory and women's political representation.»Political Studies 56(3): 725-736. DOI: https://doi.org/10.1111/j.1467-92 48.2007.00712.x

Cho, Sumi, Kimberlé Williams Crenshaw e Leslie McCall. 2013. «Toward a Field of Intersectionality Studies: Theory, Applications, and Praxis.» Signs: Journal of Women in Culture and Society 38(4): 785-810.

Crenshaw, Kimberle. 1991. «Mapping the Margins: Intersectionality, Identity Politics, and Violence Against Women of Color». Stanford Law Review 43, 1241-1299.

Dean, Jonathan. 2010. Rethinking Contemporary Feminist Politics. Basingstoke: Palgrave Macmillan.

Devitt, James. 1999. Framing Gender on the Campaign Trail: Women's Executive Leadership and the Press. Washington, DC: Women's Leadership Fund.

Francisco, Flávio. 2017. «A utopia pós-racial nos Estados Unidos: reestruturação do racismo e a ascensão de Barack Obama na era do colorblindness.» Revista de História da UEG 6(1): 01-23.

Fraser, Nancy. 2013. Fortunes of Feminism: From State-Managed Capitalism to Neoliberal Crisis. London and New York: Verso Books.

Fridkin, Kim L., Patrick J. Kenney, e Gina Serignese Woodall. 2009. «Bad for men, better for women: The impact of stereotypes during negative campaigns.» Political Behavior 31(1): 301-324.

Gill, Rosalind. 2007. «Postfeminist media culture: Elements of a sensibility.» European Journal of Cultural Studies 10(2): 147-166. DOI: https: / / doi.org/10.1177/1367549407075898

Gill, Rosalind. 2016. «Post-postfeminism?: New feminist visibilities in postfeminist times.» Feminist Media Studies 16(4): 610-630.

Goldman, Robert. 1992. Reading Ads Socially. London and New York: Routledge.

Hall, Stuart. 1997. Representation: Cultural Representations and Signifying Practices. London: Sage.

Haller, Beth. 1993. «Paternalism and Protest: Coverage of Deaf Persons in the Washington Post and the New York Times.» Comunicação apresentada à $75^{\circ}{ }^{\circ}$ Annual Meeting of 
the Association for Education in Journalism and Mass Communication (Montreal, Quebec, Canadá, 5-8 de agosto, de 1992). URL: https://files.eric.ed.gov/fulltext/ ED351698.pdf

Haraldsson, Amanda e Lena Wängnerud. 2018. «The Effect of Media Sexism on Women's Political Ambition: Evidence from a Worldwide Study.» Feminist Media Studies 19(4): 525-41. DOI: https: / / doi.org/10.1080/14680777.2018.1468797

Hayes, Danny e Jennifer L. Lawless. 2016. Women on the Run: Gender, Media, and Political Campaigns in a Polarized Era. Cambridge: Cambridge University Press.

Heflick, Nathan A. e Jamie L. Goldenberg. 2009. «Objectifying Sarah Palin: Evidence That Objectification Causes Women to Be Perceived as Less Competent and Less Fully Human.» Journal of Experimental Social Psychology 45(3): 598-601. DOI: https:/ / doi. org / 10.1016/j.jesp.2009.02.008

Joshi, Devin K., Meseret F. Hailu e Lauren J. Reising. 2019. «Violators, Virtuous, or Victims? How Global Newspapers Represent the Female Member of Parliament.» Feminist Media Studies, 1-21. DOI: https: / / 10.1080/14680777.2019.1642225

Kennedy, Tanya Ann. 2017. Historicizing Post-Discourses: Postfeminism and Postracialism in United States Culture. New York: SUNY Press.

Lazarsfeld, Paul, Bernard Berelson e Hazel Gaudet. 1944. The People's Choice: How the Voter Makes up his Mind in a Presidential Campaign. New York: Columbia University Press.

Lawless, Brandi e Yea-Wen Chen. 2019. «Developing a method of critical thematic analysis for qualitative communication inquiry.» Howard Journal of Communications 30(1): 92-106. DOI: https: / / doi.org/10.1080/10646175.2018.1439423

Lentin, Alana. 2011. «What Happens to Anti-Racism When We Are Post Race?» Feminist Legal Studies 19(2): 159-168. DOI: https: / /10.1007/s10691-011-9174-5

Lippmann, Walter. 1922. Public Opinion. New York: Macmillan.

Martins, Carla. 2015. Mulheres, Liderança Politica e Media. Lisboa: Alethêia.

McAllister, Ian. 2007. «The Personalization of Politics.» In The Oxford Handbook of Political Behavior, organizado por Russell Dalton e Hans-Dieter Klingemann, 571-588. New York: Oxford University Press.

McCombs, Maxwell E. e Donald L. Shaw. 1972. «The Agenda-Setting Function of Mass Media.» The Public Opinion Quarterly 36(2): 176-187.

McRobbie, Angela. 2004. «Post-feminism and Popular Culture.» Feminist Media Studies 4(3): 255-264. DOI: https: / / doi.org/10.1080/1468077042000309937

McRobbie, Angela. 2009. The Aftermath of Feminism: Gender, Culture and Social Change. London: Sage.

Monteiro, Rosa. 2011. «A Política de Quotas em Portugal: O papel dos partidos políticos e do feminismo de Estado». Revista Crítica de Ciências Sociais 99: 31-50. DOI: https: / / doi. org / $10.4000 /$ rccs.3953

Nogueira, Conceição. 2011. «Introdução à Teoria da Interseccionalidade nos Estudos de Género.» In Género e Ciências Sociais, organizado por Sofia Neves, 67-78. Maia: Edições ISMAI.

Owen, William Foster. 1984. «Interpretive themes in relational communication.» Quarterly Journal of Speech 70(3): 274-287.

Parashar, Swati. 2016. «Feminism and Postcolonialism: (En)gendering Encounters.» Postcolonial Studies 19(4): 371-77. DOI: https: / / doi.org/10.1080/13688790.2016.1317388

Petersen, Kirsten H. e Anna Rutherford. 1986. A Double Colonization: Colonial and Post-colonial Women's Writing. Mundelstrup, Denmark: Dangoroo Press. 
Ritchie, Jessica. 2013. «Creating a monster: Online media constructions of Hillary Clinton during the Democratic Primary Campaign, 2007-8». Feminist Media Studies 13(1): 102-119. DOI: https: / / doi.org/10.1080/14680777.2011.647973

Ross, Karen. 2002. Women, Politics, Media: Uneasy Relations in Comparative Perspective. Cresskill, NJ: Hampton Press.

Ross, Karen. 2009. Gendered Media: Women, Men and Identity Politics. Lanham, MD: Rowman \& Littlefield.

Simões, Rita Basílio. 2017. «Do escrutínio dos media aos media sob escrutínio: estereótipos de género no espaço público mediatizado.» In Pessoas e ideias em trânsito: percursos e imaginários, organizado por Rita Basílio de Simões et al., 13-35. Coimbra: Imprensa da Universidade de Coimbra.

Simões, Rita Basílio e Maria João Silveirinha. 2019. «Framing street harassment: Legal developments and popular misogyny in social media.» Feminist Media Studies 1-17. DOI: https:/ / doi.org/10.1080/14680777.2019.1704816

Spivak, Gayatri Chakravorty. 1989. «Who Claims Alterity?» In Remaking History: Discussions in Contemporary Culture, organizado por Barbara Kruger e Phil Mariani, 269-292. Seattle: Bay Press.

Spivak, Gayatri Chakravorty. 2010. Pode o subalterno falar? Novo Horizonte: Editora UFMG. Tuchman, Gay. 1978. Making News: A Study in the Construction of Reality. New York: Free Press. Tyagi, Ritu. 2014. «Understanding Postcolonial Feminism in relation with Postcolonial and Feminist Theories.» International Journal of Language and Linguistics 1(2): 45-50.

Van Aelst, Peter e Knut De Swert. 2009. «Politics in the News: Do Campaigns Matter? A Comparison of Political News During Election Periods and Routine Periods in Flanders (Belgium).» Communications 34(2): 149-68.

Vavrus, Mary Douglas. 2002. Postfeminist News: Political Women in Media Culture. Albany: State University of New York Press.

Verge, Tània e Raquel Pastor. 2018. «Women's Political Firsts and Symbolic Representation.» Journal of Women, Politics \& Policy 39(1): 26-50. DOI: https:/ / doi.org/10.1080/15544 77X.2016.1268878

Vliegenthart, Rens, Hajo G. Boomgaarden, e Jelle W. Boumans. «Changes in political news coverage: Personalization, conflict and negativity in British and Dutch newspapers.» In Political communication in postmodern democracy, organizado por Kees Brants e Katrin Voltmer, 92-110. London: Palgrave Macmillan.

Ward, Orlanda. 2017. «Intersectionality and Press Coverage of Political Campaigns: Representations of Black, Asian, and Minority Ethnic Female Candidates at the UK 2010 General Election.» International Journal of Press/Politics 22(1): 43-66. DOI: http:/ / doi.org/10.1177/1940161216673195.

Wasburn, Philo C. e Mara H. Wasburn. 2011. «Media coverage of women in politics: The curious case of Sarah Palin.» Media, Culture E Society 33(7): 1027-1041. DOI: https:/ / doi.org/10.1177/0163443711415744

Wolf, Mauro. 1987. Teorias da Comunicação. Lisboa: Editorial Presença.

Zeisler, Andi. 2016. We Were Feminists Once: From Riot Grrrl to CoverGirl, the Buying and Selling of a Political Movement. New York: Public Affairs. 
Rita Basílio de Simões. Professora Auxiliar da Faculdade de Letras da Universidade de Coimbra. Investigadora integrada do ICNOVA e investigadora associada do Centro de Estudos Sociais da Universidade de Coimbra, os seus interesses de investigação têm cruzado os estudos do jornalismo e dos media digitais e a investigação feminista em comunicação. Membro da ECREA e da APEM, coordena atualmente o Grupo de Trabalho em Género e Sexualidades da Associação Portuguesa de Ciências da Comunicação.

Endereço eletrónico: rbasilio@fl.uc.pt

Inês Amaral. Professora Associada da Faculdade de Letras da Universidade de Coimbra. Doutorada em Ciências da Comunicação pela Universidade do Minho, é investigadora integrada do Centro de Estudos de Comunicação e Sociedade e investigadora associada do Centro de Estudos Sociais da Universidade de Coimbra. Tem investigado sobre sociabilidades nas redes sociais digitais, literacia mediática e digital, tecnologias e envelhecimento ativo, audiências e consumos mediáticos na era digital.

Endereço eletrónico: ines.amaral@uc.pt

Artigo recebido em 19 de julho e aceite para publicação, após revisão, em 7 de outubro de 2020. 


\section{Estudos e Ensaios}





\title{
A IGUALDADE DE GÉNERO NAS ORGANIZAÇÕES E O EFEITO DO RECONHECIMENTO PÚBLICO: O CASO DO PRÉMIO IGUALDADE É QUALIDADE
}

\author{
Mariana Pinheiro* \\ (D) https: / / orcid.org/0000-0002-5563-5252 \\ Sara Falcão Casaca \\ (D) https: / / orcid.org/0000-0002-7944-5007
}

\section{Resumo}

Este artigo decorre de uma investigação que abrangeu as organizações distinguidas com o Prémio Igualdade é Qualidade (PIQ). Resulta da compilação, análise e categorização de todas as práticas já reconhecidas, assim como da análise de conteúdo de informação institucional. As conclusões são também sustentadas pela informação resultante de um inquérito por questionário enviado às organizações premiadas. Os resultados sugerem que as práticas reconhecidas como exemplares não estavam plenamente ancoradas numa abordagem integrada de igualdade de género. Conclui-se também que a atribuição do Prémio não tem contribuído para a efetiva institucionalização de políticas, processos e práticas de promoção da igualdade entre mulheres e homens nas organizações distinguidas.

Palavras-chave: Igualdade entre mulheres e homens, boas práticas, gender mainstreaming, Prémio Igualdade é Qualidade.

\section{Abstract \\ Gender Equality in Organisations and the Effect of Public Recognition: The Case of the Equality Is Quality Award \\ This article draws on a research study involving the organisations distinguished with the Equality is Quality Award (PIQ). It results from the compilation, analysis and categori- sation of all the recognised practices, as well as of the analysis of the content of institutional information. Conclusions are also drawn from the data gathered through the questionnaire sent to the awarded organisations. Findings suggest that the practices recognised as exem- plary were not fully embedded in a gender mainstreaming approach. It is also concluded that the award has not contributed to an effective institutionalisation of policies, processes and practices geared towards the promotion of equality between women and men in the awarded-winning organisations.}

Keywords: Equality between women and men, good practices, gender mainstreaming, Equality is Quality award.

ISEG - Lisbon School of Economics \& Management, Universidade de Lisboa.

Endereço eletrónico: marianapinheiro@aln.iseg.ulisboa.pt.

*** ISEG - Lisbon School of Economics \& Management, Universidade de Lisboa; SOCIUS - Centro de Investigação em Sociologia Económica e das Organizações/CSG, 1200-781 Lisboa, Portugal. Endereço postal: ISEG - Lisbon School of Economics \& Management, Universidade de Lisboa, Rua do Quelhas, n. ${ }^{\circ}$ 6, 1200-781 Lisboa, Portugal.

Endereço eletrónico: sarafc@iseg.ulisboa.pt 


\begin{abstract}
Resumen
Igualdad de género en las organizaciones y el efecto del reconocimiento público: el caso del premio igualdad es calidad (PIQ)

Este artículo es el resultado de una investigación que abarcó organizaciones distinguidas con el Premio Igualdad es Calidad (PIQ). Resulta de la compilación, análisis y categorización de todas las prácticas ya reconocidas, así como del análisis del contenido de información institucional. Las conclusiones también son apoyadas por información resultante de un cuestionario enviado a todas las organizaciones ya premiadas. Los resultados obtenidos sugieren que las prácticas distinguidas no estaban respaldadas por un pleno enfoque integrado de igualdad de género. Además, el premio no ha contribuido para la efectiva institucionalización de políticas, procesos y prácticas de promoción de la igualdad entre mujeres y hombres en las organizaciones premiadas.
\end{abstract}

Palabras clave: Igualdad entre mujeres y hombres, buenas prácticas, gender mainstreaming, premio Igualdad es Calidad.

\title{
Introdução
}

A Comissão para a Igualdade no Trabalho e no Emprego (CITE), desde o ano 2000, em conjunto com a Comissão para a Cidadania e a Igualdade de Género (CIG), desde 2009, têm vindo a atribuir o Prémio Igualdade é Qualidade (PIQ). Este tem como objetivo distinguir as entidades empregadoras que, para lá do cumprimento das disposições legais, apresentam políticas e práticas exemplares no domínio da igualdade entre mulheres e homens. O presente artigo decorre de uma investigação que abrangeu as organizações distinguidas com este Prémio, tendo sido guiada por duas questões fundamentais: (1) em que medida as políticas e práticas reconhecidas como exemplares estavam ancoradas numa abordagem integrada de género, estabilizada no quotidiano das organizações; e (2) se o reconhecimento público favoreceu a consolidação de políticas e práticas organizacionais promotoras de uma efetiva igualdade entre mulheres e homens. ${ }^{1}$

Foi privilegiada uma abordagem metodológica mista. Procedeu-se, num primeiro momento, à compilação, análise e categorização de todas as práticas reconhecidas como exemplares, assim como à análise (qualitativa e quantitativa) de conteúdo de informação institucional relativa a todas organizações premiadas (41, no total). Para apreender a existência de políticas e práticas de gestão (e de Gestão de Recursos Humanos) orientadas para a efetivação da igualdade entre mulheres e homens, numa fase seguinte foi enviado um inquérito por questionário a todas as organizações já distinguidas, tendo-se seguidamente procedido à análise estatística dos resultados obtidos.

O estudo insere-se num projeto de investigação mais vasto [Não identificado nesta fase para não comprometer o anonimato]. 
O texto encontra-se estruturado de modo a referenciar (sinteticamente) os contributos teóricos em torno da genderização das organizações, assim como aqueles que têm integrado uma perspetiva de género nas abordagens sobre mudança organizacional. Posteriormente, são explicitadas as opções metodológicas, sendo analisados e discutidos os resultados do estudo. Estes sugerem que as práticas reconhecidas com a atribuição do PIQ não estavam plenamente ancoradas numa abordagem integrada de igualdade de género. Conclui-se também que a atribuição do Prémio não tem contribuído para uma efetiva institucionalização de políticas, processos e práticas de promoção da igualdade entre mulheres e homens, articuladas, coerentes e estabilizadas no quotidiano das organizações.

\section{As organizações como contextos genderizados: contributos teóricos}

As desigualdades entre mulheres e homens nas organizações começaram a ser evidenciadas na década de 1970, enquadrando-se fundamentalmente em estudos feministas atentos à identificação dos processos de discriminação e de segregação sexual nas profissões e nas hierarquias das empresas (Calás, Smircich e Holvino 2014). Como recorda Acker (1990), o movimento feminista da segunda vaga denunciou as hierarquias organizacionais e as práticas burocráticas enquanto estruturas de dominação masculina que contribuíam para a opressão, o controlo e a subalternização das mulheres. A divisão sexual do trabalho nas organizações era, então, fundamentalmente atribuída ao entrosamento entre a estrutura burocrática e a estrutura patriarcal, refletido na masculinidade da autoridade burocrática (Ferguson 1984; Savage e Witz 1993). O debate teórico apresentava-se essencialmente ancorado nas abordagens estruturalistas, salientando a existência de obstáculos organizacionais estruturais e a necessidade de criação de políticas e de medidas capazes de garantir a efetiva igualdade entre mulheres e homens (e.g., Walby 1990; Witz 1997; Ferreira 1999).

A partir da década de 1980, as lentes da análise reorientaram-se para a genderização das estruturas, das práticas, dos processos organizacionais, das profissões e das hierarquias, assim como para a dimensão sexualizada do trabalho e das organizações (e.g., Acker 1990; Cockburn 1991). Deve-se essencialmente a Joan Acker, no início da década de 1990, a fundamentação teórica de que as organizações são genderizadas - i.e., que o género está incrustado nas estruturas, políticas, normas e processos organizacionais e de gestão, nas práticas e nas interações sociais que enformam o quotidiano dos contextos organizacionais. Reconhece-se que os locais de trabalho não são neutros, mas, sim, regimes de género bem definidos - espaços onde se (re) produz a divisão do trabalho entre mulheres e homens e uma estrutura de autoridade e de poder alinhada com o ideal de masculinidade hegemónica (Connell 2006).

Numa linha de pensamento pós-estruturalista, socioconstrutivista e construtivista, várias teses têm discorrido sobre a possibilidade de processos de degenderi- 
zação, geradores de transformação das estruturas e das culturas organizacionais no sentido da superação da dominação masculina. As organizações são, neste âmbito, perspetivadas como construções sociais passíveis de mudança (Bendl 2005). As mulheres e os homens, enquanto agentes ativos em contexto de trabalho, tanto podem (re)produzir as assimetrias como serem estimuladas/os a desafiar as estruturas de dominação e as relações de poder vigentes (Alvesson e Billing 2009; Lewis e Simpson, 2012).

Em síntese, o entrosamento entre contributos estruturalistas e pós-estruturalistas tem favorecido o reconhecimento da complexidade dos obstáculos que se colocam à igualdade entre mulheres e homens, ainda que estes sejam passíveis de questionamento e transformação. No percurso do desenvolvimento do pensamento teórico sobre género e organizações, há a destacar - como faremos seguidamente - a integração de uma perspetiva de género no campo científico sobre mudança organizacional.

\section{A integração de uma perspetiva de género na mudança organizacional}

A literatura gestionária sobre mudança organizacional tem sido relativamente indiferente à relevância de uma perspetiva de género, ou, quando assim não sucede, tende a propor soluções focadas nas mulheres (Fix the Women Approach), como se a situação de desvantagem laboral e profissional decorresse de limitações das mesmas e não de condicionalismos estruturais (Kolb et al. 2003). Deve-se essencialmente aos estudos alicerçados nas abordagens feministas e nos referenciais da igualdade entre mulheres e homens a fundamentação teórica e empírica sobre a importância de uma abordagem integrada de igualdade de género (gender mainstreaming) (Benschop e Verloo 2011).

A estratégia de gender mainstreaming - inicialmente integrada na Plataforma de Ação de Pequim, no contexto da Quarta Conferência Mundial das Nações Unidas sobre as Mulheres, em 1995, retomada e amplamente suportada pelo Conselho de Europa - é definida como a (re)organização, a melhoria, o desenvolvimento e a avaliação dos processos de implementação de políticas para que a perspetiva da igualdade de género seja incorporada em todas as políticas, a todos os níveis e em todas as fases, pelos atores implicados nos processos de tomada de decisão (Conselho da Europa 1998). Se, no plano macro, a integração desta abordagem visa a transformação das estruturas societais, no caso das organizações, deverá potenciar uma mudança estrutural (EIGE 2016) capaz de garantir a igualdade de oportunidades no acesso ao emprego e nas condições de trabalho, a dessegregação horizontal e vertical, a igualdade salarial e a conciliação entre a vida profissional, familiar e pessoal, criando condições de paridade na conformidade das responsabilidades profissionais e familiares (Monteiro e Ferreira 2013; veja-se também Perista et al. 2008; Casaca et al. 2016). 
De acordo com a literatura, a mudança organizacional deve ser enquadrada num processo sistémico e planeado, que passa pela adoção de um método colaborativo e participativo de investigação-ação (Ely e Meyerson 2000; OIT 2012). A integração sistemática, explícita e coerentemente articulada de uma perspetiva de igualdade entre mulheres e homens nas organizações compreende as etapas seguintes: (1) a análise sistemática (diagnóstico) das condições laborais e profissionais das mulheres e dos homens que integram a organização, das suas prioridades, necessidades e expectativas, bem como dos fatores que (direta e/ou indiretamente) condicionam a efetiva igualdade de oportunidades e de tratamento e limitam a igualdade de resultados; (2) a elaboração de planos de ação, visando a (re)organização e a melhoria dos processos de tomada de decisão, das políticas, das práticas e dos processos internos de gestão e de organização do trabalho para assegurar a incorporação transversal, em todas as áreas e a todos os níveis, da igualdade entre homens e mulheres; (3) a criação de uma infraestrutura interna estatutariamente reconhecida (comissão/comité para a igualdade entre mulheres e homens) e a alocação de recursos adequados (técnicos e financeiros); (4) a monitorização sistemática das intervenções e a realização dos ajustamentos necessários; (5) o compromisso político do topo e de todas as pessoas com responsabilidades de gestão e liderança; (5) a participação de todos os membros da organização no diagnóstico e na discussão de resultados; e (6) a capacitação de todas e todos as/os intervenientes para garantir a estabilização e a institucionalização dos novos processos de gestão e de trabalho (Casaca e Lortie 2018).

Entende-se que, além de planeado e sistémico, o processo de mudança deverá ser também gradual e contínuo (Macdonald, Sprenger e Dubel 1997), desenrolando-se a partir de pequenas vitórias (small wins) (Weick e Quinn 1999; Ely e Meyerson 2000), embora sem perder de vista uma agenda mais substantiva e estrutural, necessariamente mais prolongada no tempo (Correll, 2017).

As investigações, todavia, têm demonstrado que os projetos de mudança organizacional orientados para a promoção da igualdade de género dificilmente são verdadeiramente transformadores (Eriksson-Zetterquist e Remark 2016). Tal sucede porque, em geral, as mudanças são fragmentadas e os resultados pouco consistentes (Benschop e Verloo 2011), evidenciando a dimensão estrutural do género e a complexidade de uma agenda para a igualdade de facto entre mulheres e homens (Hearn, 2000). Acresce que muitas organizações tendem a replicar temas em voga e a adotar um discurso «politicamente correto», à revelia de uma estratégia articulada e coerente, suportada por intervenções estruturadas e pela monitorização regular dos resultados (Liff e Cameron 1997). Os estudos evidenciam que, frequentemente, a promoção da igualdade entre mulheres e homens não é priorizada pelas entidades empregadoras, concorrendo com o verdadeiro mainstream: a procura de eficiência e de rentabilidade dos negócios (Benschop e Verloo 2011). A falta de um genuíno empenhamento político das lideranças (a vários níveis da estrutura organizacional) e de envolvimento coletivo tende a gerar focos de resis- 
tência e a comprometer o alcance da mudança (Ely e Meyerson 2000). Falhas na comunicação limitam ou impedem o sentido de urgência (Kotter e Cohen 2002) e a ausência de formação em igualdade entre mulheres e homens e de ações concretas orientadas para a desconstrução de estereótipos de género são também fatores que condicionam (ou travam) o potencial de transformação (Macdonald, Sprenger e Dubel 1997; Casaca e Lortie 2018).

\section{O Prémio Igualdade é Qualidade (PIQ): origem e desenvolvimentos}

A origem do PIQ remonta às orientações delineadas no contexto do Conselho Europeu Extraordinário de Luxemburgo, nos finais de 1990. A Estratégia Europeia para o Emprego assentava em quatro pilares estruturantes (empregabilidade, espírito empresarial, adaptabilidade e igualdade de oportunidades), que deveriam ser desenvolvidos por cada Estado-membro através de um Plano Nacional de Emprego. Com o IV Pilar (Igualdade de Oportunidades), foi possível reforçar a importância da implementação de igualdade de oportunidades entre mulheres e homens, através de vários instrumentos, incluindo a atribuição de prémios a organizações que adotassem políticas exemplares nesse domínio (Rêgo 2012). O Prémio foi instituído em 2000 e visa distinguir empresas e outras entidades empregadoras (públicas, cooperativas, associações e outras sem fins lucrativos) ${ }^{2}$ que se destaquem pelo desenvolvimento e aplicação de políticas e práticas exemplares de igualdade entre mulheres e homens no emprego, na formação profissional, na conciliação entre a vida familiar e profissional, e, mais recentemente, também no domínio da prevenção e combate à violência doméstica e de género.

Tendo inicialmente sido uma iniciativa da CITE, o Prémio é, desde 2009, atribuído conjuntamente com a CIG. É composto por duas versões (Prémio e Menção Honrosa), conta com 12 edições e foram até ao momento distinguidas 41 organizações. O processo inicia-se com um período de candidaturas definido pela CITE e pela CIG, sendo disponibilizado para o efeito um formulário e o regulamento do concurso. A avaliação técnica é elaborada por uma equipa de peritas/os, sendo o resultado apreciado por um júri composto por membros da CITE $^{3}$ e, desde 2009,

2 A partir de 2010 (9. a edição), o PIQ passou a contemplar outras categorias, passando não só a ser atribuído a empresas mas, também, a outras entidades empregadoras do setor público e privado. Já em 2014 (11. a edição) passou também a ser incluída a categoria «setor da economia social». A CITE é composta por um órgão tripartido que integra um/a representante do ministério com atribuições na área do emprego, que preside, um/a representante do ministério com atribuições na área da igualdade, um/a representante do ministério com atribuições na área da Administração Pública, um/a representante do ministério com atribuições na área da solidariedade e da segurança social, dois/duas representantes de cada uma das associações sindicais com assento na Comissão Permanente de Concertação Social (CGTP-IN e UGT) e um/uma representante de cada 
também por um/a representante da CIG. Deve notar-se que, ao longo do tempo, os critérios de avaliação foram sendo progressivamente ajustados para possibilitar o cumprimento por parte de organizações de diferentes dimensões, setores, estatutos e naturezas jurídicas. Além disso, esses critérios têm vindo a refletir novas prioridades políticas; na edição de 2014, por exemplo, passou a ser integrada a dimensão «Prevenção e combate à violência doméstica e de género».

As cinco brochuras do PIQ que estão disponíveis online ${ }^{4}$, referentes às cinco últimas edições (2008/2009, 2010, 2012, 2014 e 2016/2017), contemplam as dimensões da igualdade de género que têm estado sujeitas a avaliação técnica: missão e valores; recrutamento e seleção; aprendizagem e formação contínua; avaliação de desempenho; progressão e desenvolvimento de carreiras; articulação entre a vida profissional, familiar e pessoal; respeito pela dignidade e integridade das pessoas trabalhadoras; diálogo social e participação; e combate à violência doméstica e de género (desde 2014). Estão presentemente definidos 11 objetivos que as organizações devem cumprir (V. Quadro 1). Importa notar que em algumas edições (2010, 2014 e 2016/17) apenas foram atribuídas menções honrosas, assinalando antes o potencial de boas práticas em curso.

\section{Quadro 1.}

Objetivos do PIQ

Combater a segregação profissional entre as mulheres e os homens no mercado de trabalho

Eliminar as desigualdades nos ganhos médios mensais entre as mulheres e os homens

Reduzir o diferencial entre mulheres e homens na sua integração no mercado de trabalho

Melhorar a qualidade das condições de trabalho

Sensibilizar os parceiros sociais para, ao nível da contratação coletiva, instituírem boas práticas

Aumentar a participação equilibrada das mulheres e dos homens no emprego e na formação profissional

Apoiar a empregabilidade das mulheres e dos homens em setores de atividade em que se encontrem sub-representadas/os

(continua na página seguinte)

uma das associações patronais com assento na Comissão Permanente de Concertação Social (CCP, CIP, CAP e CTP). Fonte: http:/ / cite.gov.pt/pt/acite/quemsomos.html [Acesso em 15 de novembro de 2019].

4 http:/ / cite.gov.pt/pt/premioigualdade/entidadespremiadas.html [Acesso em 15 de novembro de 2019]. 
Valorizar competências adquiridas em contexto profissional, familiar e social

Incorporar na cultura das organizações, designadamente das empresas e outras entidades empregadoras, a ideia de que a conciliação entre a vida profissional, familiar e pessoal

Promover a sensibilização das empresas e outras entidades empregadoras para a incorporação dos princípios da igualdade de género e não discriminação e da parentalidade

Prevenir a violência doméstica e de género, enquanto expressão das assimetrias de género nas relações interpessoais

Fonte: Elaboração própria com base em informação consultada em: http: / / cite.gov.pt / pt/ premio igualdade/oquepremio.html [Acesso em 01/09/2019].

\section{Análise e discussão dos resultados}

\section{Nota metodológica}

Procedeu-se, num primeiro momento, à compilação, análise e categorização de todas as práticas reconhecidas como exemplares, assim como à análise (qualitativa e quantitativa) do conteúdo de informação institucional publicada nos sites de todas as organizações premiadas (41, no total). Numa fase seguinte, foi enviado um email às pessoas responsáveis pela Gestão de Recursos Humanos (GRH) de todas as organizações distinguidas, informando sobre o estudo e pedindo a colaboração através do preenchimento de um inquérito por questionário disponibilizado online. Esta opção decorreu do facto de as candidaturas serem normalmente coordenadas pelas pessoas que dirigem os departamentos de Recursos Humanos (ou áreas equivalentes), cabendo-lhes muito frequentemente o acompanhamento das medidas de promoção da igualdade de género. Para potenciar a veracidade das respostas, foi salvaguardado o anonimato da organização respondente. Dada a sensibilidade do tema da investigação, esta foi também a principal razão para a não realização de entrevistas presenciais.

O inquérito por questionário foi estruturado de modo a identificar a existência de uma estratégia para a igualdade entre mulheres e homens, consubstanciada num plano de ação, assim como mapear as políticas, processos e práticas em vigor. A conceção inspirou-se na literatura anteriormente exposta, destacando-se o pressuposto de que a integração efetiva de uma perspetiva de género está orientada para a transformação estrutural, ancorando-se numa estratégia articulada e coerente, refletida em políticas, processos e práticas institucionalizadas e estabilizadas nas organizações premiadas. A análise efetuada procurou, assim, dar resposta às questões orientadoras do estudo: (1) em que medida as políticas e práticas organizacionais distinguidas com o PIQ estavam ancoradas numa abordagem inte- 
grada de género, estabilizadas no quotidiano dessas organizações; e (2) se o reconhecimento público favoreceu a consolidação de políticas e práticas organizacionais promotoras da igualdade entre mulheres e homens.

\section{Caracterização das organizações e das práticas premiadas}

No decurso de 12 edições do PIQ, foram distinguidas 41 organizações (18 prémios e 41 menções honrosas). Em alguns casos, houve organizações que foram distinguidas mais do que uma vez (ver Anexo 1). A esmagadora maioria (33) detém capital privado (lucrativo), três são associações ou cooperativas e cinco são de capital público. As organizações distinguidas operam em ramos diversos, desde as atividades financeiras e seguros, passando pela indústria automóvel, transformadora, gráfica, metalúrgica e metalomecânica, e, ainda, comércio por grosso e a retalho, atividades de saúde humana e apoio social, atividades imobiliárias, atividades de informática e conexas, e transportes e armazenagem.

Analisando as práticas distinguidas, destacam-se fundamentalmente aquelas relacionadas com a articulação entre a vida profissional, familiar e pessoal. Algumas organizações foram também reconhecidas por: utilização de linguagem inclusiva e de imagens não discriminatórias em função do sexo; assunção do compromisso com a igualdade de género enquanto valor fundamental da organização; adoção de medidas de apoio ao recrutamento e seleção de mulheres e de homens para cargos em que o sexo esteja sub-representado; apoio à formação a mulheres que pretendam potenciar as suas competências técnicas, de liderança e de gestão; disponibilização de ações de sensibilização para a igualdade entre mulheres e homens e sobre a conciliação trabalho-família; incentivo do gozo das licenças parentais por parte dos homens, bem como do uso da licença parental inicial partilhada; e adoção de mecanismos de apoio ao combate da violência doméstica.

Constatámos, a partir da análise ao conteúdo dos sites das 41 organizações distinguidas, que mais de um terço (15) são atualmente membros do iGen - Fórum de Organizações para a Igualdade (criado em 2013 e que tem como missão promover uma cultura coletiva de responsabilidade social e justiça, incorporando nas suas estratégias de gestão os princípios da igualdade e não discriminação entre mulheres e homens no mercado de trabalho). ${ }^{5}$ Causou surpresa, porém, o facto de apenas 5 das 41 organizações ( $12 \%$ do total) fazerem referência à igualdade de género na missão e nos valores. Apenas uma organização divulga publicamente $o$ respetivo Plano para a Igualdade entre Mulheres e Homens, e somente seis fazem referência ao facto de terem sido distinguidas com o PIQ.

Fonte: http:/ / forumigen.cite.gov.pt/ (Acesso em 22 de novembro de 2019). 


\section{Caracterização das organizações participantes no estudo}

De um universo de 41 organizações contactadas, obtiveram-se 22 respostas ( $54 \%$ do total) ao inquérito por questionário. Destas, mais de metade $(57 \%)$ é de grande dimensão, empregando mais de 250 trabalhadores/as e tendo um volume de negócios anual superior a 50 milhões de euros. Com um balanço total anual superior a 43 milhões de euros, 33\% e 10\% são entidades empregadoras de média e pequena dimensão, respetivamente. Seis organizações integram o setor empresarial do Estado, duas são da administração pública local, duas são instituições privadas de solidariedade social (IPSS), e 11 são empresas privadas. ${ }^{6}$

Quanto à caracterização do pessoal ao serviço ${ }^{7}, 36 \%$ das 22 organizações respondentes são constituídas por mais homens do que mulheres, sendo que $18 \%$ (4) apresentam uma representação equilibrada de trabalhadores e trabalhadoras. Assim, predominam as organizações $(46 \%)$ com mais mulheres do que homens. Deve destacar-se, no entanto, que cerca de três quartos $(78 \%)$ das organizações apresentam uma maior percentagem de homens em cargos de direção de primeira linha, e apenas $18 \%$ apresentam uma representação equilibrada de mulheres e homens nesses cargos. Quanto ao número de mulheres e homens que ocupam cargos de direção de topo, apenas duas organizações apresentam maior percentagem de mulheres nestes cargos. Em síntese, as organizações representadas na amostra são maioritariamente compostas por trabalhadoras; no entanto, os cargos mais elevados na hierarquia são maioritariamente ocupados por homens.

Efeitos da atribuição do PIQ nas políticas e práticas promotoras da igualdade entre mulheres e homens

Para a esmagadora maioria das organizações, a atribuição do PIQ contribuiu para a consolidação de políticas de gestão e práticas organizacionais promotoras da igualdade entre mulheres e homens (Figura 1). No entanto, tal não sucedeu em cerca de um quinto das mesmas. No mesmo registo, igual proporção não tem em vigor um Plano para a Igualdade entre Mulheres e Homens (PIMH).

Uma organização não respondeu à respetiva questão.

A análise da caracterização do pessoal ao serviço da organização foi feita através de uma avaliação global das respostas dadas pelas organizações, uma vez que foi garantido o anonimato. 


\section{Figura 1.}

Existência de um PIMH e Consequências da atribuição do PIQ

Existe um Plano para a Igualdade entre Mulheres e Homens?

A atribuição do PIQ (seja na sua versão Prémio ou de Menção Honrosa) estimulou a consolidação de políticas de gestão e práticas organizacionais promotoras da igualdade entre mulheres e homens na organização?

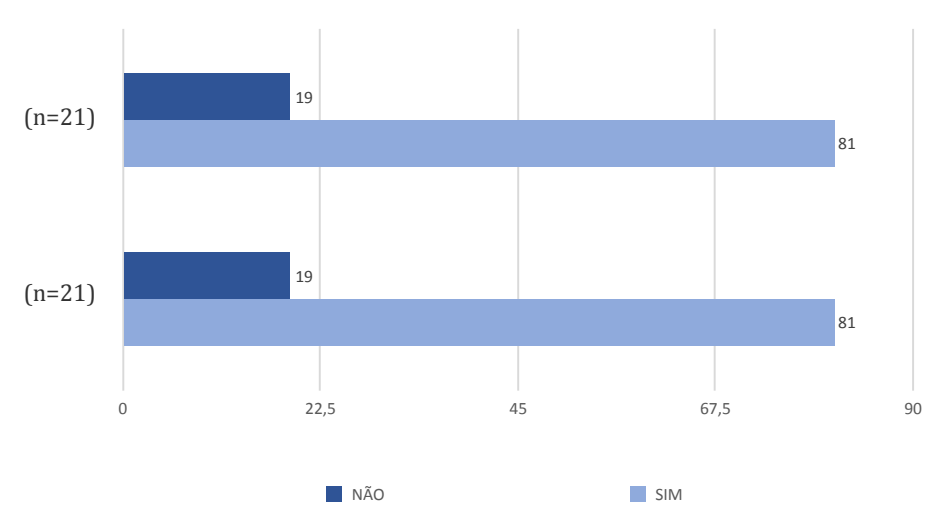

Mais de metade das entidades respondentes não passou a integrar temas associados à igualdade entre mulheres e homens nos planos de formação destinados a trabalhadores e trabalhadoras (Figura 2). Fazendo a ponte com os contributos teóricos sobre a mudança organizacional, trata-se de uma lacuna considerável, uma vez que a capacitação é fundamental para que se efetive a integração de uma perspetiva de género nas políticas e práticas organizacionais (Perista et al. 2008; Monteiro e Ferreira 2013; Casaca et al. 2016; Casaca e Lortie 2018).

\section{Figura 2.}

Integração da Temática «Igualdade entre Mulheres e Homens» nos Planos de Formação

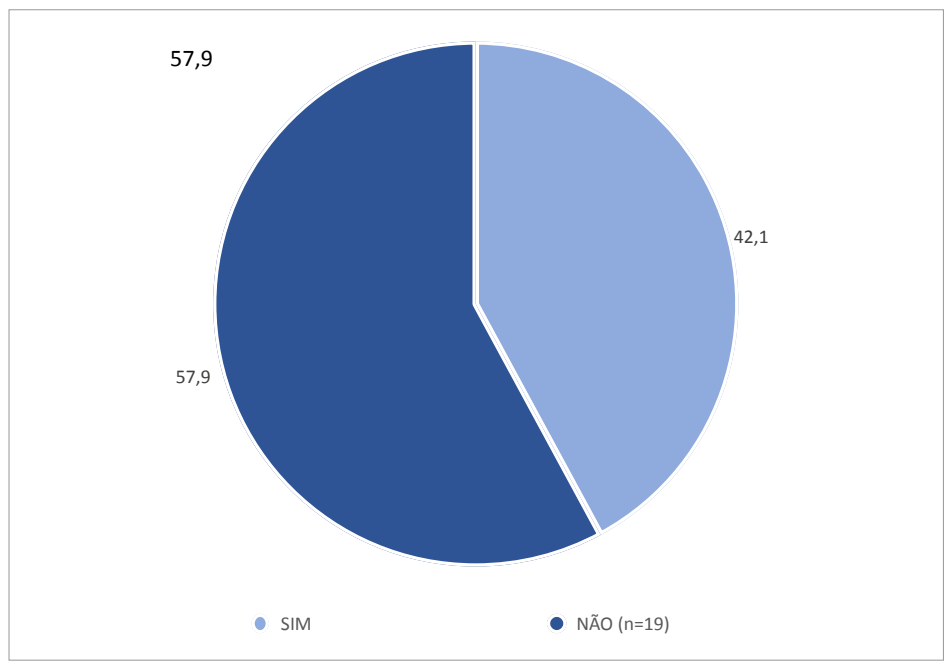


Deve ainda notar-se que em mais de metade das organizações (53\%) não está implementado qualquer procedimento que garanta a prevenção de diferenciais remuneratórios injustificados entre homens e mulheres. Esta constatação não deixa de causar surpresa, uma vez que um dos objetivos do PIQ é a eliminação das desigualdades salariais.

\section{Figura 3.}

Implementação de procedimentos de monitorização dos salários das mulheres e dos homens

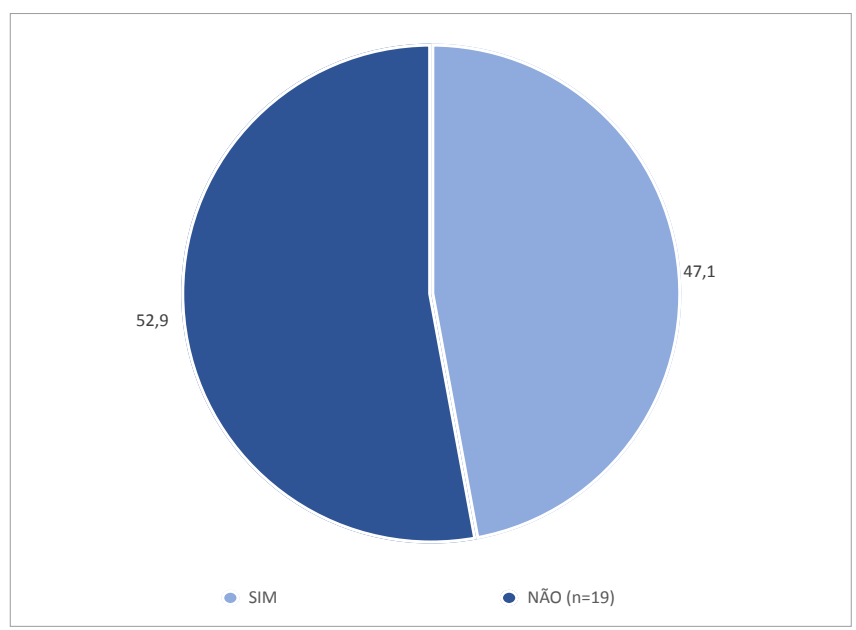

Importa referir que em mais de metade (53\%) das organizações respondentes a atribuição do PIQ não incentivou a adoção de medidas para o acesso de homens e mulheres a profissões/funções onde estejam sub-representados/as (Figura 4). É de assinalar, todavia, que contrariar a segregação sexual profissional é igualmente umas das prioridades do PIQ. No mesmo registo, um número considerável não procedeu à definição de objetivos para alcançar o equilíbrio entre mulheres e homens em cargos de chefia $(44 \%)$ ou de direção de topo $(56 \%)$.

Em aproximadamente três quartos das organizações respondentes estão definidas medidas específicas para facilitar a articulação entre a vida profissional, familiar e pessoal, além do disposto na Lei e/ou nos Instrumentos de Regulamentação Coletiva de Trabalho (Figura 5). É de sublinhar, porém, que em quase metade $(44 \%)$ não existem mecanismos institucionalizados de informação e consulta de trabalhadores e trabalhadoras relacionados com questões de igualdade entre mulheres e homens, articulação entre a vida profissional, familiar e pessoal, e proteção da parentalidade. 
Figura 4.

Existência de medidas para promover homens ou mulheres a cargos de chefia de nível intermédio ou a cargos de direção de topo; Efeito do PIQ na adoção de medidas para o acesso de homens e mulheres a profissões / funções onde estejam sub-representados/as, como consequência da atribuição do PIQ

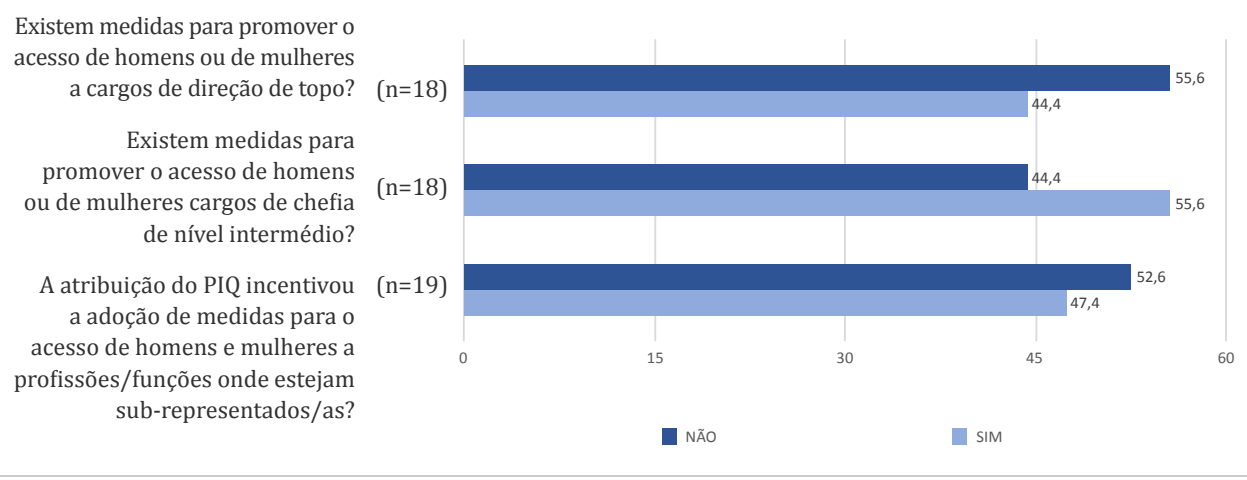

Figura 5.

Implementação de mecanismos institucionalizados de informação e consulta de trabalhadoras e trabalhadores relacionados com questões de igualdade entre mulheres e homens, articulação entre a vida profissional, familiar e pessoal, e proteção da parentalidade;

Medidas facilitadoras da articulação entre a vida profissional, familiar e pessoal

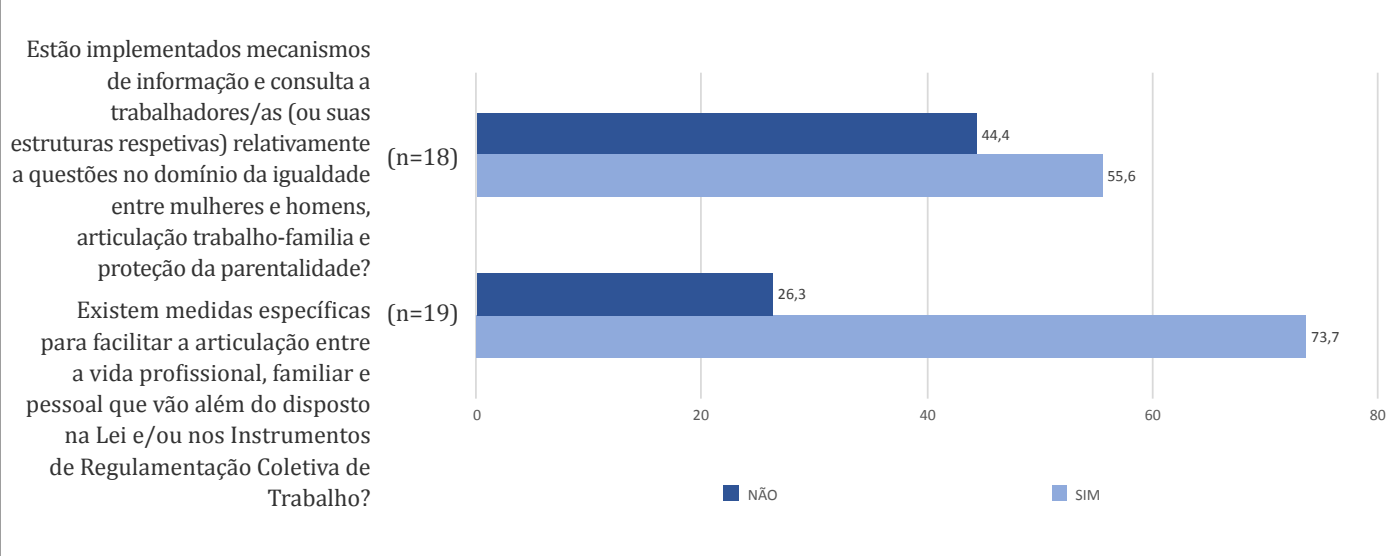

Por fim, constata-se que cerca de um quarto das organizações respondentes ainda não dispõe de procedimentos específicos para a apresentação e apreciação de queixas, não estando igualmente definidas sanções em casos de assédio sexual e/ou moral e de outras formas de violência de género no local de trabalho. 


\section{Figura 6.}

Existência de procedimentos específicos para apresentação e apreciação de queixas e estabelecimento de sanções em casos de assédio sexual e/ ou moral e outras formas de violência de género no local de trabalho

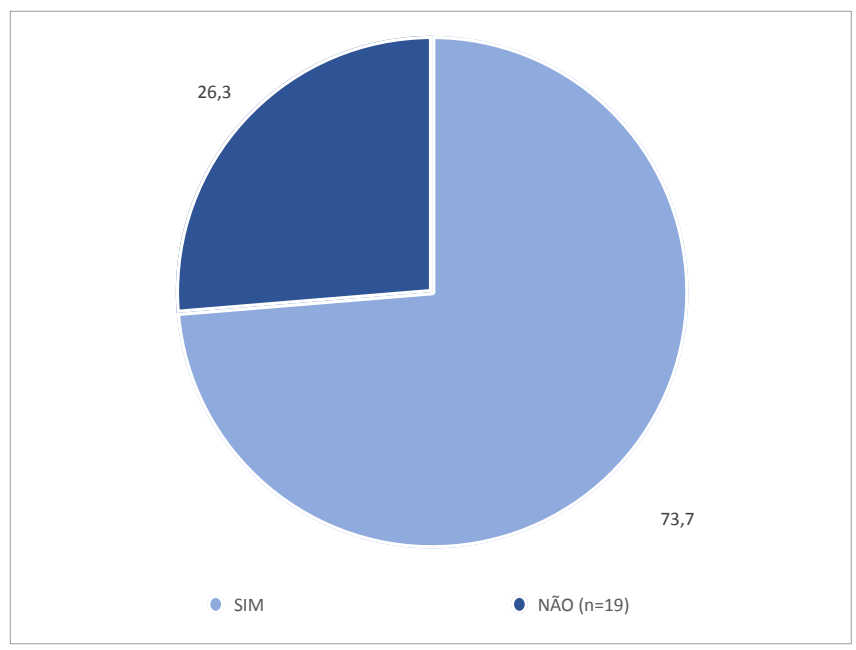

\section{Conclusões e considerações finais}

Foram distinguidas no país, desde o ano 2000, cerca de quatro dezenas de organizações pela adoção de políticas e práticas exemplares em matéria de igualdade entre mulheres e homens. A partir da análise ao conteúdo de informação institucional deste universo, publicada nos respetivos sites, foi possível apurar que a esmagadora maioria das organizações não explicita publicamente o compromisso com a igualdade de género na missão e nos valores, e que apenas uma organização divulga o Plano para a Igualdade entre Mulheres e Homens em vigor. É também residual o número daquelas que divulga a atribuição do Prémio e/ou da Menção Honrosa.

Cerca de metade das organizações distinguidas participou no estudo através da resposta a um inquérito por questionário. Foi possível apurar que, na perceção da ampla maioria, a atribuição do PIQ estimulou a consolidação de políticas e práticas promotoras da igualdade entre mulheres e homens; no entanto, este não é um sentido de resposta unânime. Esta evidência encontra correspondência em todas as dimensões analisadas, expondo fragilidades no que diz respeito a: adoção de uma estratégia para a igualdade consubstanciada num plano de ação; integração da igualdade entre mulheres e homens nas ações de formação; adoção de medidas orientadas para a dessegregação horizontal e vertical; monitorização sistemática das remunerações das mulheres e dos homens para garantir que não exis- 
tem diferenciais injustificados; criação de mecanismos institucionalizados de informação e consulta de trabalhadores/as relacionados com questões de igualdade entre mulheres e homens, articulação entre a vida profissional, familiar e pessoal, e proteção da parentalidade; e adoção de procedimentos específicos para a apresentação e apreciação de queixas em casos de assédio sexual e/ou moral e de outras formas de violência de género no local de trabalho.

Os resultados obtidos sugerem que as práticas reconhecidas com a atribuição do PIQ não estavam plenamente ancoradas numa abordagem integrada de igualdade de género (gender mainstreaming). A evidente ausência de referência à igualdade entre mulheres e homens, no quadro da explicitação da missão e dos valores da esmagadora maioria das organizações premiadas, é demonstrativa da fragilidade dessa abordagem. Não se afigura também possível associar o reconhecimento público a um processo de transformação estrutural, orientado para a institucionalização de políticas, processos e práticas de promoção da igualdade entre mulheres e homens, num registo articulado, coerente e estabilizado no quotidiano das organizações.

Reconhece-se que a pesquisa aqui apresentada tem limitações. Além de não se ter conseguido reunir respostas de todo o universo de organizações distinguidas, não se nos afigurou possível mobilizar uma abordagem metodológica facilitadora de uma análise mais profunda e compreensiva. No entanto, tratando-se do primeiro estudo acerca do PIQ, os resultados vêm estimular uma reflexão académica, política e pública sobre os objetivos e o alcance do Prémio. Perante os resultados obtidos, afigura-se-nos relevante sugerir a atribuição muito criteriosa de um selo ou distintivo a organizações com práticas exemplares (em curso ou implementadas), necessariamente ancoradas numa abordagem efetiva de promoção da igualdade entre mulheres e homens. A distinção deverá carecer de renovação em cada quinquénio, em função da prestação de provas de manutenção/consolidação desse compromisso por parte das organizações distinguidas.

A presente investigação deixa em aberto várias questões em torno dos constrangimentos institucionais que se colocam à plena consecução de uma abordagem integrada de género. $\mathrm{O}$ presente trabalho expõe, aliás, a necessidade de um maior desenvolvimento do campo científico sobre género e organizações em Portugal.

\section{Referências bibliográficas}

Acker, Joan. 1990. «Hierarchies, jobs, bodies: a theory of gendered organizations.» Gender $\mathcal{E}$ Society 4 (2): 139-158. DOI: https:/ / doi.org /10.1177/089124390004002002.

Alvesson, Mats, e Yvonne Due Billing. 2009. Understanding gender in organizations. London: Sage.

Benschop, Yvonne, e Mieke Verloo. 2011. «Gender change, organizational change, and gender equality strategies.» In Handbook of Gender, Work \& Organization, organizado por Emma L. Jeannes, David Knights, e Patricia Y. Martin, 277-290. John Wiley \& Sons. 
Bendl, Regine. 2005. Revisiting Organization Theory - Integration and Deconstruction of Gender and Transformation of Organization Theory. Berlin: Peter Lang.

Calás, Marta B., Linda Smircich, e Evangelina Holvino. 2014. «Theorizing gender and organizations.» In The Oxford Handbook of Gender in Organizations, organizado por Savita Kumra, Ruth Simpson, e Ronald J. Burke, 17-52. Oxford: Oxford University Press.

Casaca, Sara Falcão, Heloísa Perista, Anália Torres, Catarina Correia, Eudelina Quintal, e Patrícia São João. 2016. Guia para a Promoção da Igualdade entre Mulheres e Homens. Lisboa: CIG. Disponível em http:/ / cite.gov.pt/pt/destaques/noticia506.html.

Casaca, Sara Falcão, e Johanne Lortie. 2018. Género e Mudança Organizacional. Turim: Centro Internacional de Formação da OIT. Disponível em: https:/ /www.ilo.org/lisbon/ publica\%C3\%A7\%C3\%B5es/WCMS_682648/lang--pt/index.htm.

Cockburn, Cynthia. 1991. In the Way of Women - Men's resistance to sex equality in Organizations. London: Macmillan.

Conselho da Europa. 1998. Gender Mainstreaming. Conceptual Framework, Methodology and Presentation of Good Practices. Strasbourg: Council of Europe. Disponível em: https: / / www.unhcr.org/3c160b06a.pdf.

Connell, Raewyn. 2006. «Glass ceilings or gendered institutions? Mapping the gender regimes of public sector worksites.» Public Administration Review 66 (6): 837-849. JSTOR: https: / / www.jstor.org/stable/4096601.

Correll, Shelley. 2017. «Reducing gender biases in modern workplaces: a small wins approach to organizational change.» Gender $\mathcal{E}$ Society 31 (6): 725-750. DOI: https:/ / doi.org/10.1177/0891243217738518.

EIGE - Instituto Europeu para a Igualdade de Género. 2016. Institutional Transformation Gender Mainstreaming Toolkit. Disponível em: https: / / eige.europa.eu/publications / institutional-transformation-gender-mainstreaming-toolkit.

Ely, Robin J., e Debra Meyerson. 2000. «Theories of gender in organizations: a new approach to organizational analysis and change.» Research in Organizatinal Behaviour 22: 103-151. DOI: https: / / doi.org/10.1016/S0191-3085(00)22004-2.

Eriksson-Zetterquist, Ulla, e David Renemark. 2016. "Can changes to gender equality be sustained?» Gender, Work E Organization 23 (4):363-378. DOI: https: / / doi.org / 10.1111/ gwao.12127.

Ferguson, Kathy. 1984. The Feminist Case against Bureaucracy. Philadelphia, PA: Temple University Press.

Ferreira, Virgínia. 1999. «Os paradoxos da situação das mulheres em Portugal.» Revista Crítica de Ciências Sociais 52-53: 199-227. Disponível em: https://ces.uc.pt/rccs/index. php?id=676.

Hearn, Jeff. 2000. «On the complexity of feminist interventions in organizations.» Organization 7 (4): 609-624. DOI: https:/ / doi.org/10.1177/135050840074006.

Kolb, Deborah, Joyce K. Fletcher, Debra E. Meyerson, Deborah Merrill-Sands, e Robin J. Ely. 2003. «Making change: a framework for promoting gender equity in organizations.» In Reader in Gender, Work and Organization, organizado por Robin J. Ely, Erica G. Foldy, Maureen A. Scully, e The Center for Gender in Organizations Simmons School, 10-25. Oxford: Blackwell Publishing.

Kotter, John P. e Cohen, Dan S. 2002. The Heart of Change: Real-life Stories of How People Change Their Organizations, Boston, MA: Harvard Business School Press.

Lewis, Patricia e Simpson, Ruth. 2012. «Kanter revisited: gender, power and (in)visibility.» International Journal of Management Review 14 (2): 141-158. DOI: https: / / doi.org/10.11 $11 / \mathrm{j} .1468-2370.2011 .00327$. 
Liff, Sonia; Cameron, Ivy. 1997. «Changing equality cultures to move beyond 'women's problems.» Gender, Work E Organization 4 (1): 35-46. DOI: https: / / doi.org/10.1111/ 14 68-0432.00022.

Macdonald, Mandy, Ellen Sprenger, e Irene Dubel. 1997. Gender and Organizational Change: Bridging the Gap between Policy and Practice. Amsterdam: Royal Tropical Institute.

Monteiro, Rosa, e Virgínia Ferreira. 2013. «Planos para a igualdade género nas organizações: Contributos para o desenho e realização dos diagnósticos organizacionais.» Sociedade e Trabalho 43-44-45: 123-136. Disponível em: http:/ / hdl.handle.net/10316/ 43897.

OIT - Organização Internacional do Trabalho. 2012. A Manual for Gender Audit Facilitators: The ILO Participatory Gender Audit Methodology. 2nd ed. Genève: International Labour Organization. Disponível em: https://www.ilo.org/wcmsp5/groups/public/---dgreports /---gender/documents/publication/wcms_187411.pdf.

Perista, Heloísa, Maria das Dores Guerreiro, Clara Jesus, e Maria Luísa Moreno. 2008. «A igualdade de género no quadro da responsabilidade social - o projecto EQUAL, diálogo social e igualdade nas empresas.» ex aequo 18: 103-120. Disponível em: http:/ / hdl.handle.net / $10071 / 13526$.

Rêgo, Maria do Céu da Cunha. 2012. «Políticas de igualdade de género na União Europeia e em Portugal: Influências e incoerências.» ex aequo 25: 29-44. Disponível em: http:/ / www.scielo.mec.pt/scielo.php?script=sci_arttext\&pid=S0874-55602012000100004.

Savage, Mike e Anne Witz (eds.). 1993. Gender and Bureaucracy. Oxford: Blackwell.

Walby, Sylvia. 1990. Theorizing Patriarchy. Oxford: Basil Blackwell.

Weick, Karl E., e Robert E. Quinn. 1999. «Organizational Change and Development.» Annual Review of Psychology 50: 361-386. DOI: https: / / doi.org/10.1146/ annurev.psych.50.1.361.

Witz, Anne. 1997. «Women's work». In Introducing Women's Studies: Feminist Theory and Practice, organizado por Victoria Robinson, e Diane Richardson, 239-257. London: Macmillan Education.

Mariana Pinheiro é socióloga e investigadora do Projeto Mulheres nos Órgãos de Gestão das Empresas: uma abordagem integrada (WoB), financiado pela Fundação para a Ciência e a Tecnologia, desenvolvido pelo Centro de Investigação em Sociologia Económica e das Organizações (SOCIUS), do Instituto Superior de Economia e Gestão, Universidade de Lisboa.

Endereço eletrónico: marianapinheiro@aln.iseg.ulisboa.pt

Sara Falcão Casaca é Professora Associada com Agregação do Instituto Superior de Economia e Gestão, Universidade de Lisboa, investigadora integrada do Centro de Investigação em Sociologia Económica e das Organizações (SOCIUS)/Consórcio em Ciências Sociais e Gestão (CSG), onde coordena a linha de investigação Trabalho, Emprego, Organizações e Género. É coordenadora do Programa de Doutoramento em Sociologia Económica e das Organizações.

Endereço eletrónico: sarafc@iseg.ulisboa.pt

Autora correspondente:

ISEG - Lisbon School of Economics \& Management

Universidade de Lisboa

Rua do Quelhas, n. ${ }^{\circ}$ 6, 1200-781 Lisboa - Portugal 
Anexo 1.

Lista das organizações distinguidas com o Prémio Igualdade É Qualidade

\begin{tabular}{|c|c|c|}
\hline Centro Hospitalar de Setúbal, E.P.E. & Menção Honrosa & $2016 / 2017$ \\
\hline $\begin{array}{l}\text { SIMAS, Oeiras e Amadora - Serviços } \\
\text { Municipalizados }\end{array}$ & Menção Honrosa & $2016 / 2017$ \\
\hline REN - Redes Energéticas Nacionais, SGPS, S.A. & Menção Honrosa & $2016 / 2017$ \\
\hline RENAULT Cacia, S.A. & Menção Honrosa & $2016 / 2017$ \\
\hline \multirow{2}{*}{$\begin{array}{l}\text { Associação DIANOVA Portugal - Intervenção } \\
\text { em Toxicodependências e Desenvolvimento } \\
\text { Social }\end{array}$} & Menção Honrosa & $2016 / 2017$ \\
\hline & Menção Honrosa & 2014 \\
\hline \multirow{2}{*}{$\begin{array}{l}\text { GEBALIS - Gestão do Arrendamento Social } \\
\text { em Bairros Municipais de Lisboa, E.M., S.A. }\end{array}$} & Menção Honrosa & 2014 \\
\hline & Menção Honrosa & 2010 \\
\hline AUCHAN Portugal Hipermercados, S.A. & Menção Honrosa & 2014 \\
\hline Banco Santander Totta & Prémio & 2012 \\
\hline \multirow{2}{*}{ Imprensa Nacional - Casa da Moeda } & Prémio & 2000 \\
\hline & Menção Honrosa & 2012 \\
\hline Ciclo Fapril - Indústrias Metalúrgicas, S.A. & Menção Honrosa & 2010 \\
\hline \multirow{2}{*}{$\begin{array}{l}\text { Espaço t - Associação para Apoio à Integração } \\
\text { Social e Comunitária }\end{array}$} & Menção Honrosa & $2002,2004,2010$ \\
\hline & Prémio & 2005-2006 \\
\hline $\begin{array}{l}\text { Nova Gráfica de Amaral Rodrigues Resendes \& } \\
\text { Medeiros, Lda }\end{array}$ & Menção Honrosa & 2008-2009, 2010 \\
\hline $\begin{array}{l}\text { Serviços Municipalizados de Águas e Saneamento } \\
\text { da Câmara Municipal de Loures }\end{array}$ & Menção Honrosa & 2001, 2008-2009, 2010 \\
\hline AXA Seguros Portugal, S.A & Prémio & 2005-2006, 2008-2009 \\
\hline IKEA Portugal - Moveis e Decoração, Lda. & Prémio & 2008-2009 \\
\hline Metalomecânica Vítor Monteiro, Lda. & Menção Honrosa & 2008-2009 \\
\hline ORACLE Portugal, Sistemas de Informação, Lda. & Menção Honrosa & $2004,2007,2008-2009$ \\
\hline \multirow{2}{*}{ Companhia Portuguesa de Hipermercados, S.A. } & Prémio & 2007 \\
\hline & Menção Honrosa & $2005-2006$ \\
\hline \multirow{2}{*}{ Nestlé Portugal, S.A. } & Prémio & 2007 \\
\hline & Menção Honrosa & 2002 \\
\hline Grafe Publicidade, Lda. & Menção Honrosa & 2001, 2003, 2007 \\
\hline TAP Portugal, S.A. & Menção Honrosa & 2000,2007 \\
\hline $\begin{array}{l}\text { Xerox Portugal - Equipamentos de Escritório, } \\
\text { Lda. }\end{array}$ & Prémio & 2007,2000 \\
\hline Somague Engenharia, S.A. & Menção Honrosa & $2005-2006$ \\
\hline Caixa Económica Montepio Geral & Prémio & 2000,2004 \\
\hline
\end{tabular}


E RECONHECIMENTO PÚBLICO

\begin{tabular}{lll}
\hline Companhia IBM Portuguesa & Prémio & 2004 \\
\hline $\begin{array}{l}\text { Friedrich Grohe Portugal, Componentes } \\
\text { Sanitários, Lda. }\end{array}$ & Prémio & 2003 \\
\hline Luízes Representações, Lda. & Menção Honrosa & 2003 \\
\hline $\begin{array}{l}\text { ADE - Associação para o Desenvolvimento } \\
\text { e Emprego }\end{array}$ & Menção Honrosa & 2003 \\
\hline $\begin{array}{l}\text { Caixa de Crédito Agrícola Mútuo de Mafra, } \\
\text { C.R.L. }\end{array}$ & Prémio & 2002 \\
\hline $\begin{array}{l}\text { Texto Editora, Lda. } \\
\text { Opel Portugal, Comércio e Indústria, S.A. }\end{array}$ & Prémio & 2002 \\
\hline $\begin{array}{l}\text { Cooperativa Agrícola de Reguengos de } \\
\text { Monsaraz }\end{array}$ & Menção Honrosa & 2001 \\
\hline $\begin{array}{l}\text { EBAHL - Equipamentos Bairros Históricos } \\
\text { de Lisboa, E.M. }\end{array}$ & Menção Honrosa & 2001 \\
\hline Farmácia Barreiros & Menção Honrosa & 2001 \\
\hline RES - Prestação de Serviços Comerciais, S.A. & Menção Honrosa & 2001 \\
\hline Bruno Janz & Prémio & 2000 \\
\hline Heska (Atualmente Lisgráfica) & Prémio & 2000 \\
\hline Salvador Caetano & Prémio & 2000 \\
\hline A. Silva Matos Metalomecânica, S.A. & Menção Honrosa & 2000 \\
\hline RTP - Radio Televisão Portuguesa, S.A. & Menção Honrosa & 2000 \\
\hline $\begin{array}{l}\text { Tavares de Oliveira - Assessores e Consultores } \\
\text { de Empresas, Lda. }\end{array}$ & Menção Honrosa & 2000 \\
\hline Por & & 2001 \\
\hline
\end{tabular}

Fonte: Elaboração própria 



\title{
ARCHITECT LUZ VALENTE-PEREIRA: ARCHITECTURE, RESEARCH, AND LIFE IN A CHANGING COUNTRY
}

\author{
Patrícia Santos Pedrosa* \\ (D) https: / / orcid.org/0000-0001-9524-1437 \\ Lia Gil Antunes: \\ (D) https: / / orcid.org/0000-0002-5066-4062
}

\begin{abstract}
Luz Valente-Pereira (b. 1934, Lisbon) is a key figure of the $20^{\text {th }}$ century Portuguese History of Architecture, albeit a forgotten one. This research is a starting point for establishing a more solid biography of this pioneer who initiated the first decades of female participation in the architectural field in Portugal. After some professional experience in different contexts, she developed a stable research career at the National Laboratory of Civil Engineering (LNEC) with studies on various spatial scales. We have used different methodologies: bibliographical review, consultation of national archives, and an interview with her. Our proposal is not only to create female references but also to broaden the historical readings on women's participation in Portugal throughout the $20^{\text {th }}$ century.
\end{abstract}

Keywords: History of Architecture, research, women architects, Portugal.

\section{Resumo}

Luz Valente-Pereira: Arquitetura, investigação e vida num país em transformação

Luz Valente-Pereira (n. 1934, Lisboa) é um nome incontornável da História da Arquitetura portuguesa do século XX, embora tenha ficado na sombra. Esta pesquisa tem por objetivo ser um ponto de partida para fixar uma linha biográfica mais sólida de uma pioneira que iniciou as primeiras décadas de participação feminina na arquitetura em Portugal. Depois de algumas experiências profissionais, desenvolveu uma estável carreira na investigação no Laboratório Nacional de Engenharia Civil (LNEC) com estudos sobre diversas escalas espaciais. Diferentes metodologias foram aplicadas: revisão bibliográfica, consulta de arquivos nacionais e uma entrevista a Luz Valente-Pereira. A proposta é não só a criação de referências femininas, mas também a ampliação de leituras históricas sobre a participação das mulheres em Portugal no século XX.

Palavras-chave: História da Arquitetura, investigação, arquitetas, Portugal.

* Centro Interdisciplinar de Estudos de Género do Instituto de Ciências Sociais e Políticas da Universidade de Lisboa - CIEG/ISCSP-ULisboa, 1300-666 Lisboa, Departamento de Engenharia Civil e Arquitetura da Universidade da Beira Interior (Deca-UBI, 6201-001 Covilhã), Portugal. Endereço postal: Rua Almerindo Lessa, Gab 7 | Bloco Tejo | Piso - 1 - 1300-663 Lisboa, Portugal. Endereço eletrónico: pat.pedrosa@gmail.com

* Centro Interdisciplinar de Estudos de Género do Instituto de Ciências Sociais e Políticas da Universidade de Lisboa - CIEG/ISCSP-ULisboa, 1300-666 Lisboa, Portugal.

Endereço postal: Rua Almerindo Lessa Gab 7 | Bloco Tejo | Piso - 1 - 1300-663 Lisboa, Portugal. Endereço eletrónico: liapantunes@gmail.com 


\section{Resumen}

Luz Valente-Pereira: Arquitectura, investigación y vida en un país en transformación

Luz Valente-Pereira (n. 1934, Lisboa) es un nombre ineludible de la Historia de la Arquitectura portuguesa del siglo XX, aunque en la sombra. Esta investigación pretende ser un punto de partida para establecer una línea biográfica más sólida de una pionera que inició las primeras décadas de participación femenina en la arquitectura en Portugal. Después de algunas experiencias profesionales, desarrolló una carrera estable en la investigación en el Laboratorio Nacional de Ingeniería Civil (LNEC) con estudios en varias escalas espaciales. Se aplicaron diferentes metodologías: revisión bibliográfica, consulta de archivos nacionales y una entrevista a Luz Valente-Pereira. La propuesta no es solo la creación de referencias femeninas, sino también la expansión de lecturas históricas sobre la participación de las mujeres en Portugal en el siglo XX.

Palabras clave: Historia de la Arquitectura, investigación, arquitectas, Portugal.

\section{Introduction}

Researching new subjects and approaches is a demanding and challenging task. This text stems from this contradictory place: if we have not yet established basic research regarding the history of women architects in Portugal, how can we produce a critical and intersectional reflection? The broader scope of the research project «W@ARCH.PT Women Architects: Building Visibility, 1942-1986» ${ }^{1}$ is an attempt to begin writing the history of women architects in Portugal systematically and coherently. The lines of action are various and complex, and so is the group being studied. On the one hand, understanding why and how women - as a diverse group - disappear from Architecture, and developing a feminist historiography in Architecture. ${ }^{2}$ On the other hand, recovering names, works and contributions: not only from women architects commonly associated with the practice of architectural design but also from those who followed diverse professional paths inside and outside the discipline, or who were unable to complete their training. Writing women's biographies means countering their lack of recognition as active historical subjects and, consequently, the dearth of references for new generations. Biographical articles remain relevant, especially in the construction of the History of Women. Although this work focuses on an «exceptional woman», the wider research project highlights the diversity and complexity of women's lives as a heterogeneous group. Archival work and the gathering of oral testimonies are crucial methods if we want to understand the role

W@ARCH.PT is a research project funded by the Portuguese Foundation for Science and Technology (FCT), which has been developed since 2018 at the Research Centre on Gender Studies (CIEG-ISCSP) of the University of Lisbon.

2 On the feminist historiography underpinning the W@ARCH.PT, see Pedrosa (2019). 
of Portuguese women architects, ${ }^{3}$ expanding the narratives on architectural culture in Portugal. Considering the lack of research on this topic and the need to achieve historical justice, this article arises as a starting point for locating Maria da Luz Valente-Pereira in her field of action and tracing her biographical and professional path. The main source of information was our interview with her (Valente-Pereira 2019), ${ }^{4}$ coupled with archival material and the bibliographical review of her publications. The work of other researchers on similar issues and the history of the National Laboratory of Civil Engineering (LNEC) have also been taken into account.

In Portugal, the production of knowledge related to architecture and the city began much later than in nearby countries. The construction of these bodies of historical, theoretical and critical knowledge became more established in the 1960s with the works of Nuno Portas (b. 1934) or Pedro Vieira de Almeida (1933-2011), among others. The intensification of the relationship between Portuguese architects and international colleagues, mostly from Southern Europe, as well as the emergence of a generation of architects with growing critical and social awareness, led to a change in the production of theoretical, critical and historical discourses mainly focused on the issues of dwellings. The main paradigm shift relates to the emergence of critical thinking, in contrast to the opinionated discourse usually found in the Portuguese context (Pedrosa 2010).

Although her extensive work is unfairly unknown and unstudied - both within the Portuguese History of Architecture and academic courses -, the architect Luz Valente-Pereira (b. 1934, Lisbon) was part of an emerging group of researchers of architecture and the city. Her work spans over four decades of Portuguese history (Figure 1). Born during the Estado Novo dictatorship (1933-1974), hers is the story of a young woman whose university education and initial professional experiences took place in the context of an authoritarian regime. ${ }^{5}$ Between those long years and the introduction of democracy in Portugal on 25 April 1974, she developed extensive, diverse and robust research at the LNEC, ranging from housing to broader issues such as cities and urban and regional planning.

3 For a general framework on the contexts of women architects in Portugal, see Pedrosa (2015), Antunes (2016), Pérez-Moreno and Pedrosa (2020). For biographies of Portuguese women architects, see Roxo (2016), Carvalho (2020), Milheiro and Fiúza (2020).

4 The interview with Luz Valente-Pereira, conducted by Patrícia Santos Pedrosa and Lia Gil Antunes, was recorded - audio and video - on 20 December 2019, in the architect's house in Alenquer. It lasted approximately four hours and was partially transcribed. We have chosen an open-ended type of interview, with questions aimed at establishing previously gathered information, as well as information provided by the interviewee herself. Given the interviewee's advanced age, her husband has helped clarified a few chronological imprecisions.

5 For more information on the conditions of Portuguese women, see, for example, Pimentel (2011), Tavares (2011), Pimentel and Melo (2015). 
Figure 1.

Synthesis of the academic and professional path of Luz Valente-Pereira crossed with political regimes in Portugal. Source: Research project W@ARCH.PT - Women Architects in Portugal: Building Visibility, 1942-1986.

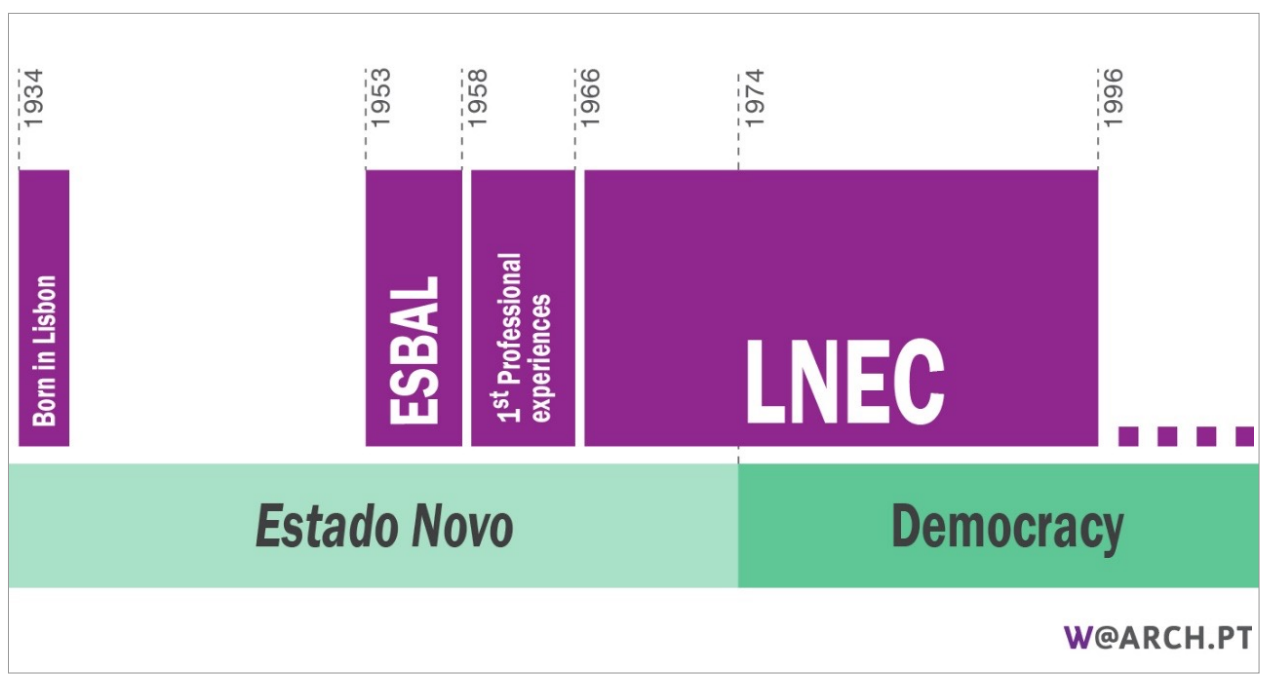

\section{Architectural Education and Initial Professional Experiences}

Born in a traditional bourgeois family, Luz Valente-Pereira (Figure 2) was encouraged from an early age to value independence, responsibility, and freedom. In her own words, she was 'educated as a man', excused from household duties to study, which was 'her only obligation', to 'acquire the ability to express herself, to be useful, to know how to solve problems through an activity [and] to be independent' (Valente-Pereira 2018, 40). However, when referring to these years of early education, she underlines that 'it was essential to respect the socially correct and, for a girl, it was, above all, important to behave to avoid creating a bad reputation' (Valente-Pereira 2018, 40).

In her youth, she attended drawing classes, where she met extraordinary people such as the Portuguese writer and poet Natália Correia (1923-1993). She claims to have chosen to study architecture without conviction: on the one hand, nothing else interested her; on the other hand, she liked arts and drawing. With only a feeble idea about the meaning of the architecture profession and, amid the Estado Novo dictatorship, she started an Architecture degree at the School of Fine Arts in Lisbon (ESBAL) in 1953, completing the course units five years later (Valente-Pereira 2018, 40). 
Figure 2.

Photo of Luz Valente-Pereira during the interview conducted by the research project W@ARCH.PT, on 20 December 2019 (Valente-Pereira 2019).

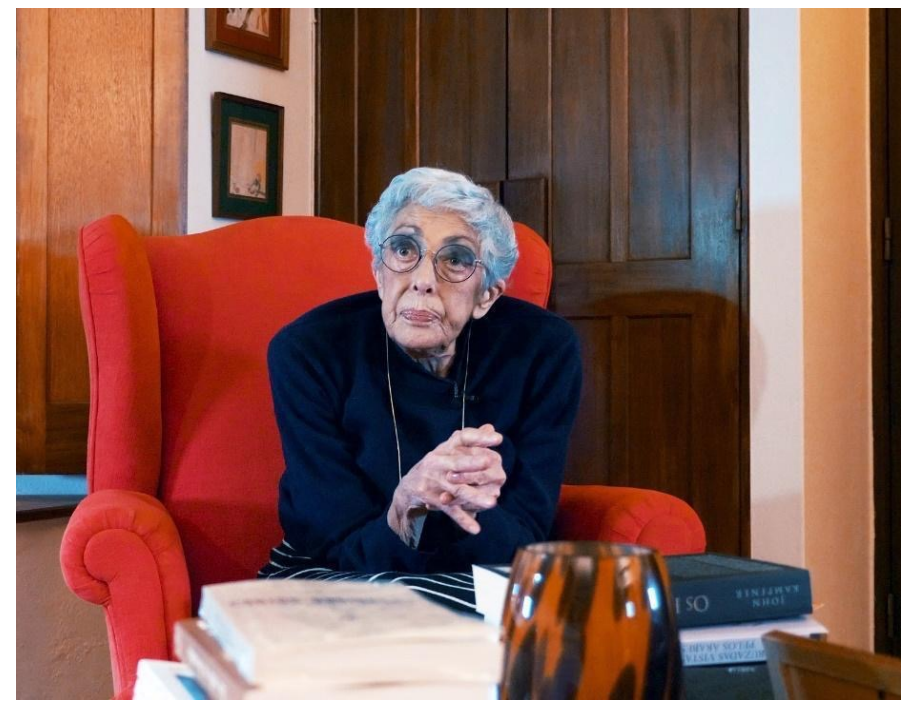

After finishing the academic part of the architecture degree, she completed pedagogical subjects at the Faculty of Arts and Humanities of the University of Lisbon, which allowed her to teach drawing in high school. This experience proved to be unstimulating and, consequently, she immediately returned to architecture. During a stay in Porto, she became aware of international opportunities and decided to take a risk. In the early 1960s, she worked for a year at the French studio Société d'Études Techniques et d'Aménagements Planifiés, where she collaborated with one of the founders, the French architect and urbanist Guy Lagneau (1915-1996). During this experience, she lived in Paris and spent some time in Africa, where she developed a project proposal for a village in the Abidjan region of the Ivory Coast. On her return to Lisbon, she joined the studio of the Portuguese architect Nuno Teotónio Pereira (1922-2016). Her collaboration in this architectural studio focused mainly on single-family housing projects. Here, she had direct contact with architectural design practices and she soon realized that she was not interested in this type of work.

Looking for other experiences and challenges within the discipline, she secured an annual scholarship from the United Nations and the opportunity to reflect on the problem of growth and planning in 'developing countries'. With this goal, she attended a postgraduate course in Regional Planning and Development at the Institut de Recherche et Formation en Vue du Développement Harmonisé, in Paris, between 1962 and 1963. This highly interdisciplinary course also allowed 
her to meet people from all over the world. When she returned to Portugal in 1963, she was invited to participate, for two years, in the team of the Aveiro Regional Plan, which was coordinated by the French architect and urban planner Robert Auzelle. Valente-Pereira's skills and urban knowledge were put to good use in the preparation of the Master Plan for the City of Lisbon (1965-1966). Here, she mainly focused on the necessary surveys. As she referred in the interview, these experiences in urban planning also proved unrewarding (Valente-Pereira 2019).

\section{Research Career at the LNEC - The Scale of Dwellings}

The course of her professional life changed in 1966. Between June 1966 and March 1996, at the LNEC in Lisbon, she established a stable career in research, obtaining a specialist degree and the position of research coordinator. After all the professional experiences mentioned above, she found the joy of 'being paid to study' (Valente-Pereira 2018, 42). Over these three decades, she extended her architectural studies to urban sociology and, particularly, to the issues of urban housing, form and rehabilitation. She has represented the LNEC and Portugal in numerous international, technical and scientific meetings. Our interview with her allowed us to discover and deepen some aspects of her work that had not been previously charted - for example, her conferences in Brazil, France, Belgium and Italy (Valente-Pereira 2019).

In 1962, Nuno Portas joined the LNEC as Head of the Construction and Housing Division and later teamed up with Luz Valente-Pereira and Francisco David Carvalho da Silva Dias (Carvalho 2012, 47). Regarding the creation and first years of the small architecture research centre at the LNEC, Portas ${ }^{6}$ said:

we went there as architects. Then I brought Maria da Luz Valente-Pereira, who was extraordinary, [...] she was almost always the one who conducted the surveys. [She] treated the more sociological questions, since at one point she devoted herself to urban sociology and worked directly with sociologists. (Carvalho 2012, 291)

Luz Valente-Pereira and Portas conducted ground-breaking work. They were regularly active in researching and proposing solutions not only for housing problems beyond a physical dimension, but also for the complexities of urban life and form. ${ }^{7}$ Mariana Carvalho wrote about the well-renowned Portas in the context of the LNEC, mentioning that

for the first time there was a group of architects in Portugal that guaranteed the necessary conditions for carrying out an investigation of architectural interest.

Interview with Nuno Portas in March 2011, carried out by the architect Mariana Carvalho (2012). These questions had been under discussion internationally since the 1950s, at least. Despite the constraints of the dictatorship, Portuguese architects were able to access part of these discussions. 
In this way, through population surveys, Nuno Portas, together with Maria da Luz Valente-Pereira, an intern architect, sought to gather conclusions about the 'lifestyle' and tastes of the respondents, who lived in so-called social housing. (Carvalho 2012, 111)

This group was part of the Centre for Architecture and Urbanism (NAU) at LNEC, which established a 'long tradition of research in architecture' (LNEC 2011, 1). Concerning urban studies, a new group emerged in $1987,{ }^{8}$ which included Luz Valente-Pereira, Fernando Gonçalves and Vitor Campos. Later, the group was dissolved and these researchers re-joined NAU (2011).

The revolutionary studies of Luz Valente-Pereira allowed analyses and diagnoses that supported the definition of residential quality. These have made it possible to understand the activities performed at home and the availability of space, as well as the organization and satisfaction provided by different types of dwellings. In addition to the constructive, architectural and urban approach, the perceptions and uses of the inhabitants' spaces became part of the project, namely the analysis of residential satisfaction, well-being, and symbolic dimensions, such as the use and appropriation of residential areas (Freitas, Menezes, and Coelho 1996). This research with strong links to social aspects resulted in a series of reports concerning the everyday lives of people within an urban environment. This research project, co-authored by Portas, includes surveys of family needs in terms of urban housing (Portas and Valente-Pereira 1967). Applied to national social housing needs, they identified what activities were performed inside the house and how houses should be equipped, organized and sized, as a way of guaranteeing the best living conditions. In 1967, Luz Valente-Pereira produced a document that outlined the classification, designation and minimum requirements for social housing in urban centres. Some observations and ideas taken from this research were summarized in an article published in 1968 in the newspaper Diário de Lisboa ${ }^{9}$ (Figure 3), i.e., they were shared with the general public. Based on the questions, 'Do the houses that we build satisfy residents?' and 'What houses should be built?' (Valente-Pereira 1968, 4), Luz Valente-Pereira was able to critically comment on the notion of minimum in housing and to study the activities that take place at home and/or in public space/urban furniture, the organization of houses and their uses, and the need to define satisfactory minimum programs. In the context of a complex topic, she offered some clues regarding housing planning, stressing that houses should follow the evolution of living standards - sociocultural and technicaleconomic - and of the family itself. Rising up to these challenges, she pointed out the importance of the 'elasticity of dwellings', related to the degree of mobility of families and the need to know the existing reality (Valente-Pereira 1968, 6).

Urbanism and Municipal Planning Group.

This was part of a series of works on Architects and Urbanism organized by the Portuguese Union of Architects in collaboration with Diário de Lisboa. 
Figure 3.

Excerpt from the text «As casas que se constroem» [The houses that are built], by Luz Valente-Pereira, published in the newspaper Diário de Lisboa, Lisbon, Portugal, August 8, 1968 (Valente-Pereira 1968, 4).

\section{As casas qua se constroem}
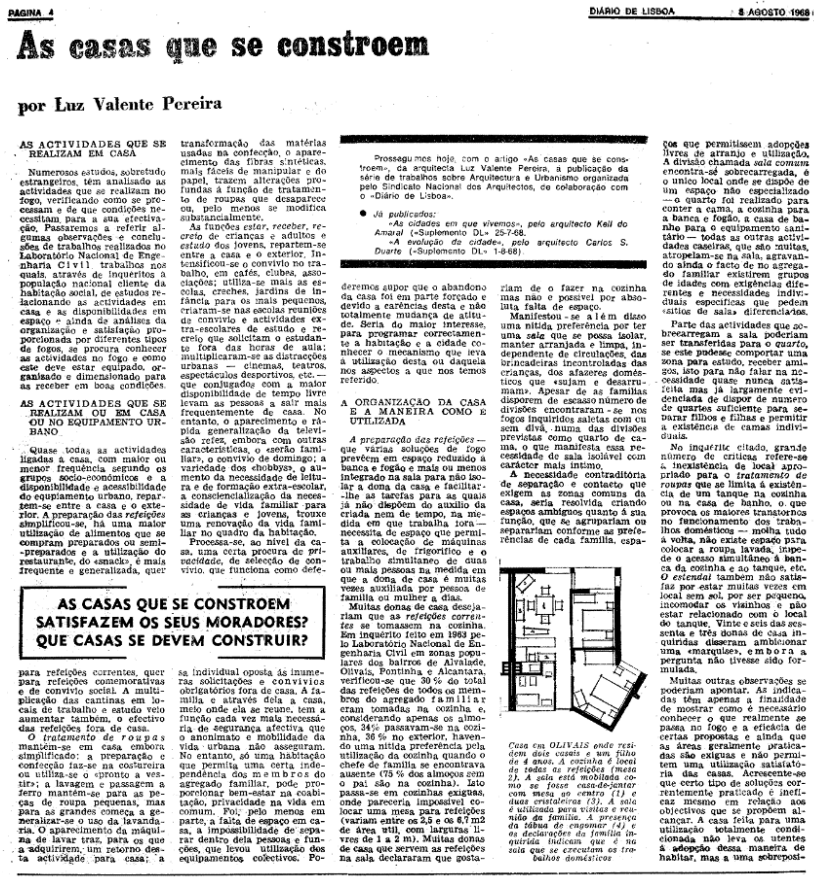

In the early 1970s, Luz Valente-Pereira resumed and developed the survey on urban housing by questioning the issue and design of methodologies (ValentePereira and Gago 1972, 1974a, 1974b; Valente-Pereira 1977a, 1977b, 1977c). When designing, analysing and evaluating survey data, more than knowing what area was suitable for a particular household, it was crucial to know what led each individual to use a particular space and how it was used. Among other relevant conclusions, Luz Valente-Pereira highlighted two main ideas. On the one hand, that a house must be adaptable and malleable to the circumstances of each family and inhabitant; on the other hand, that this type of study has actively, and for a long time, been used by the modernists to justify minimal and inflexible spaces, especially in so-called social housing for the disadvantaged populations (ValentePereira 2019).

In July 1970, with some professional experience under her belt, Luz ValentePereira presented the final project to earn her degree in architecture. Drawing on the aforementioned studies, she officially concluded her training as an architect. Her research intensified throughout that decade. In 1977, she published several surveys 
on the use and space of houses (Valente-Pereira 1977a, 1977b, 1977c). These reflections continued and, alongside the sociologist Maria Amélia Baptista Corrêa Gago, she focused on field research concerning building planning. They then synthesized the sample's characteristics and the conclusions of these surveys in a publication (Figure 4) on the use of space in dwellings (Valente-Pereira and Gago 1974c).

Figure 4.

Page of the book O Uso do Espaço na Habitação [The Use of Space in the Household], showing 'Example 1 - Table of activities - meals' and 'Example 2 - House plan'

(Valente-Pereira and Gago 1974c, 4).

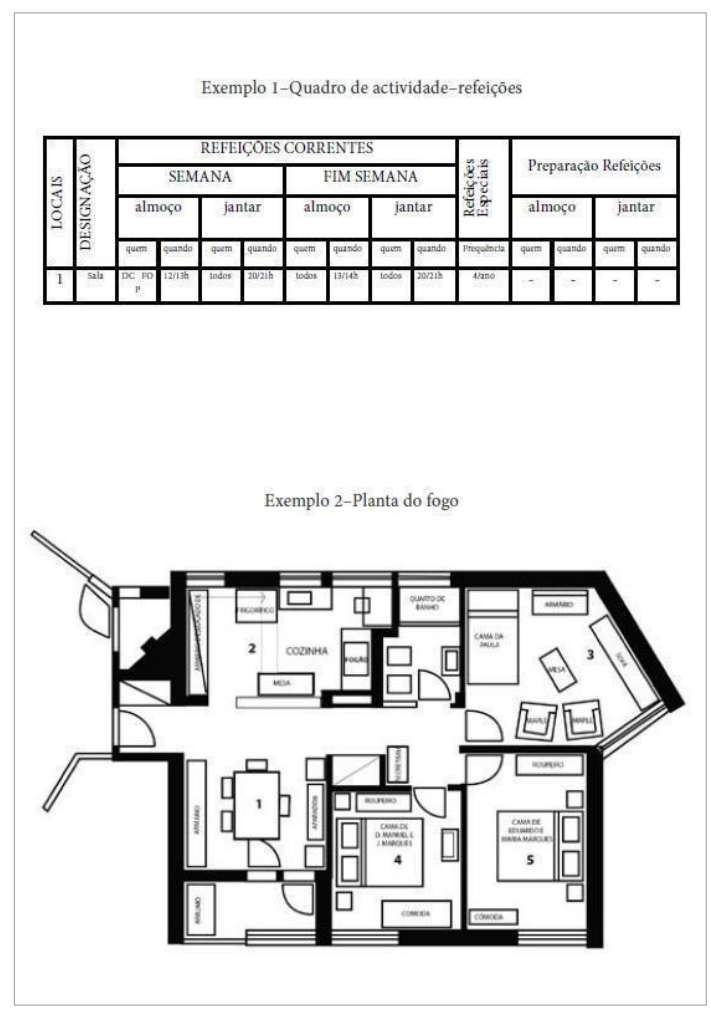

\section{Research Career at the LNEC - The City Scale}

Luz Valente-Pereira's studies began to expand from housing issues to the complexities of urban spaces. ${ }^{10}$ Realizing the relations between the uses of interior 10 We can find a similar path - from dwellings to the city - in the work of Nuno Portas (See, for
example: 1964 and 2003-2011). 
and exterior spaces, the house and the city, she designed and carried out a survey on the use of the city (Valente-Pereira 1971a) ${ }^{11}$ (Figure 5). In 1971, she applied for an expert position as the LNEC with a proposal for an urban system model (Valente-Pereira 1971b). This work resulted from her previous research. ${ }^{12}$ Following the international debate on architecture, she applied a mathematical model to the analysis of the city, supported by the Theory of Systems. The aim was to 'represent the urban system so that one can obtain and manipulate the necessary information to intervene in it, thus programming alternative project proposals for the construction of urban space' (Valente-Pereira 1973, 5). As she commented in the interview (Valente-Pereira 2019), this study allowed her to achieve two main goals, as well as criticize this deterministic approach: on the one hand, to establish relationships and understand the complexity of the urban reality; on the other hand, to prove that mathematical models are not sufficient to encompass the full diversity of urban life, i.e., they are unable 'to capture the city' (Valente-Pereira 2019). Following these studies on urban relations, she was invited to conferences (Jornal do Brasil 1972, 19) and to promote the specialization course 'Urban architecture: methods and criteria for design', in Brazil, in 1972 ${ }^{13}$ (Figure 6). As Luz Valente-Pereira referred, besides being well-attended, this event led a few Brazilian universities to incorporate her publications into their syllabuses - which is yet to happen in Portugal (Valente-Pereira 2019).

After the restoration of democracy brought by the Carnation Revolution on 25 April 1974, Luz Valente-Pereira transposed the issues discussed in Brazil to European contexts - for example, Liège, Strasbourg and Nancy - and was surprised to find out that they were still relevant in starkly different geographical, social and economic realities. In Portugal, given the accumulated knowledge and data on housing issues, she participated - albeit discreetly - in the Local Ambulatory Support Service, better known as the SAAL Process (1974-76). ${ }^{14}$ José Bandeirinha (2011) analysed this moment accurately. He referred that the joint project meetings ${ }^{15}$

11 This study later led to the book The Use of the City-A study on the City of Lisbon (Valente-Pereira 1990).

12 She also published the entire process: the preparation of the survey (Valente-Pereira 1971c), the collection and analysis of data, as well as the design of analytical methods and plans (ValentePereira 1971d). The conception of a pilot survey on the use of the city and the application of a model of analysis of urban behaviors would later structure a dynamic model of analysis of the urban system applied to the urban scale (Valente-Pereira 1973).

13 The course was repeated in 1973 and 1974 (Universities of Brasília, São Paulo and Rio de Janeiro). Luz Valente-Pereira underlined the fact that they always took place during her holidays, since the LNEC did not want to be institutionally involved in them (Valente-Pereira 2019).

14 SAAL - Serviço de Apoio Ambulatório Local was a renovation process of the Portuguese housing stock aimed at disadvantaged populations, in which the inhabitants participated.

15 These meetings focused on the presentation of projects and the preparation of several studies on three main topics: (i) bureaucratic aspects, (ii) technical and economic aspects and (iii) political aspects. 
Figure 5.

Cover of the book A Utilização da Cidade: um estudo sobre a cidade de Lisboa [The Use of the City. A Study on the City of Lisbon] (Valente-Pereira 1990).

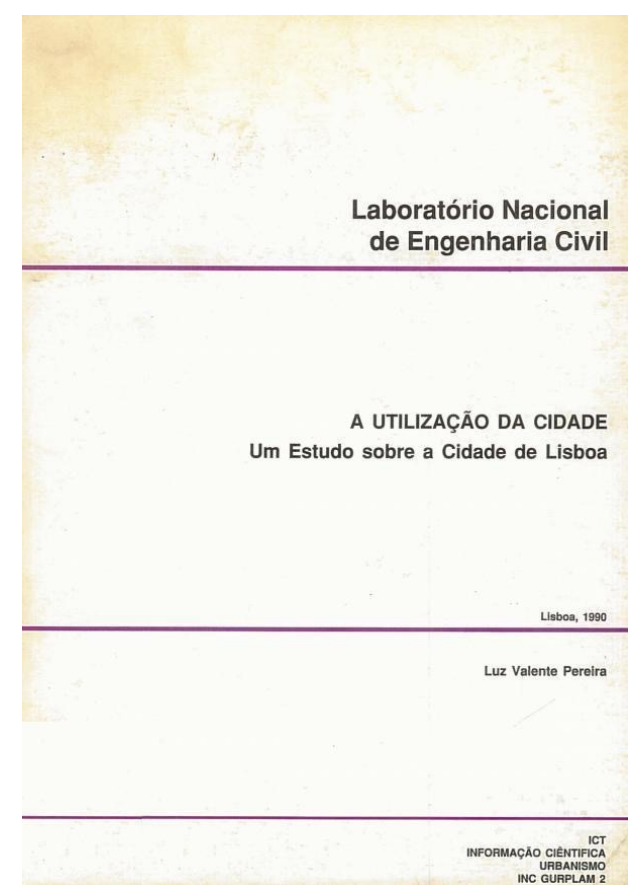

had the 'participation of technicians from the brigades, services, FFH [Fundo de Fomento da Habitação, Housing Development Fund] and other organizations'. This participation included 'figures such as Abel Reina, Fernando Bagulho, José Miguel da Fonseca, Cruz Henriques, João Gomes Horta, Teresa Sá and Luz ValentePereira' (Bandeirinha 2011, 196). These architects included a group of experts considered 'elements of direct support', who, according to Bandeirinha,

proposed the creation of a new regulatory body for the development of projects, which stemmed from the confrontation between SAAL's action and the action of other urban players (and corrected the latter). They believed that the General Regulation on Urban Buildings (RGEU) in effect at the time was 'outdated and completely inadequate' and felt that SAAL's operations should be developed 'outside of any prior regulation that was external to the process'. (Bandeirinha 2011, 210)

After her admission to the Association of Portuguese Architects - member 1685 - in 1981, Luz Valente-Pereira participated in the 2nd Congress of this organization under the theme 'The Architects and Spatial Planning'. During the 


\section{Figure 6.}

Newspaper article 'Arquiteta portuguesa diz que não existe receita para construção de cidade' [Portuguese female architect says there is no recipe for building a city], published in the urbanism section of the newspaper Jornal do Brasil, September 24, 1972, reporting on the conference by Luz Valente-Pereira at the School of Architecture of the Federal University of Minas Gerais, Brazil, on the goals and methods of analysing urban space (Jornal do Brasil 1972, 19).

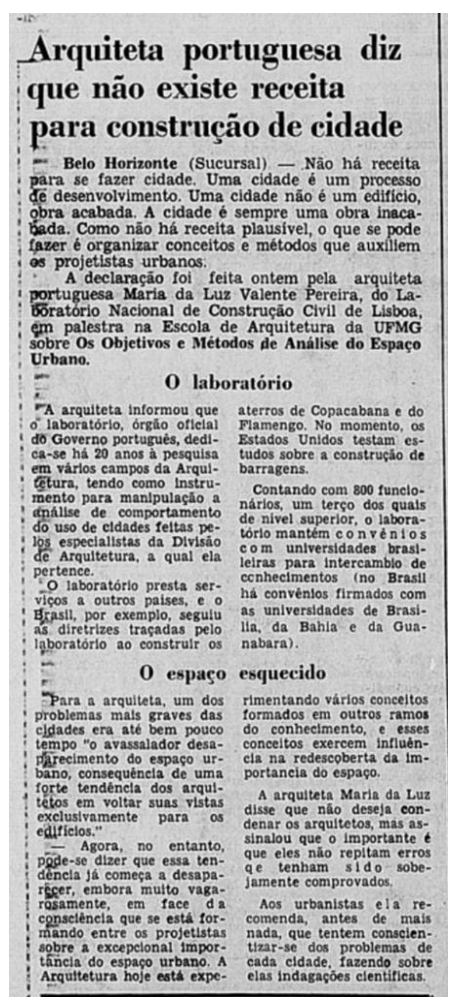

event held at the LNEC, in Lisbon, between 12 and 15 November 1981, Luz Valente-Pereira focused on the 'urban space as an architectural object - consequences in terms of planning, design and professional practices' (Valente-Pereira 1981a). The 1980s brought about new contexts and professional challenges for Luz ValentePereira, not only due to the instability that marked the consolidation of democracy but also the departure of Nuno Portas from the LNEC. ${ }^{16}$ Between 1979 and 1982,

16 In 1974, Portas assumed the role of Secretary of State for Housing and Urbanism onj the 1st Provisional Government. Therefore, the organization was left with no leader. As Valente-Pereira mentioned, even though she had no interest in it, no invitation was made to her (Valente-Pereira 2019). 
Luz Valente-Pereira became a consultant for the FFH as a result of her professional experience in the previous decades, as well as her ability to merge various thematic scales. At this stage, as she highlighted in the interview, she also worked as a consultant for the team of the Almada-Monte da Caparica Integrated Plan. She found an empty and expectant public land with a modernist plan divided into three large areas occupied by different views of the city belonging to each of the three architects involved. ${ }^{17}$ Through critical reflections to connect these interventions, Luz Valente-Pereira raised issues concerning the construction processes of the city, while consolidating questions about what the urban form is and how it is defined (Valente-Pereira 2019).

When we analysed Luz Valente-Pereira's research from the 1980s to the mid1990s, we found three essential axes. First, the urban form, ${ }^{18}$ its definition and key concepts (Figure 7) (Valente-Pereira 1982, 1983a, 1987a); second, urban rehabilitation, ${ }^{19}$ on which she wrote a seminal work (1987b); finally, urban, municipal and regional planning..$^{20}$ The various problems raised by municipal planning led to the establishment of the foundations of a methodological renewal (Valente-Pereira 1984a), the development of essays on the policies and strategies of municipal action $^{21}$ and the design of a Method for the technical support of the socio-urban development of an area of urban intervention (Valente-Pereira 1986b). ${ }^{22}$ The critical questioning of the myriad facets of urban planning surpassed the scope of the research. Luz Valente-Pereira collaborated from its inception in the Plan to Safeguard the Old Centre of Sacavém, ${ }^{23}$ both as a consultant and project coordinator (Figure 8). Invited by Maria João Gonçalves, the municipal architect, Luz Valente-Pereira was able to assess the applicability of the previously studied methods in a real-life situation. Although the project was short-lived and ended without any political commitment, during the interview, Luz Valente-Pereira praised the teamwork of the technical council group and the involvement of the population - residents and business owners - in discussions and events ${ }^{24}$ (Valente-Pereira 2019). The professional career of Luz Valente-Pereira ended in 1996, when she retired and left LNEC.

Project team: João Paciência, Vasco Costa and João Andrade.

18 These publications were later recovered; see, for example, Marat-Mendes, Almeida, and Borges (2019).

19 See also Valente-Pereira (1991, 1994).

20 On this topic, she also published: Valente-Pereira (1981b, 1983b, 1986a).

$21 \quad$ See, for example: Valente-Pereira (1984b).

22 Technical information composed of two volumes dedicated, respectively, to the methodology (Valente-Pereira 1986b) and the planning and programming of short-term interventions (Valente-Pereira 1987c).

23 As she remarked in the interview, the initial challenge for the meta-plan was a free and quick first approach to the characteristics of the predefined territory and the constraints of the project itself, without a 'limiting program' (Valente-Pereira 2019).

$24 \quad$ Events such as the car-free day in Sacavém's city centre.
} 
Figure 7.

Cover of the book Arquitectura Urbana [Urban Architecture] (Valente-Pereira. 1987a).

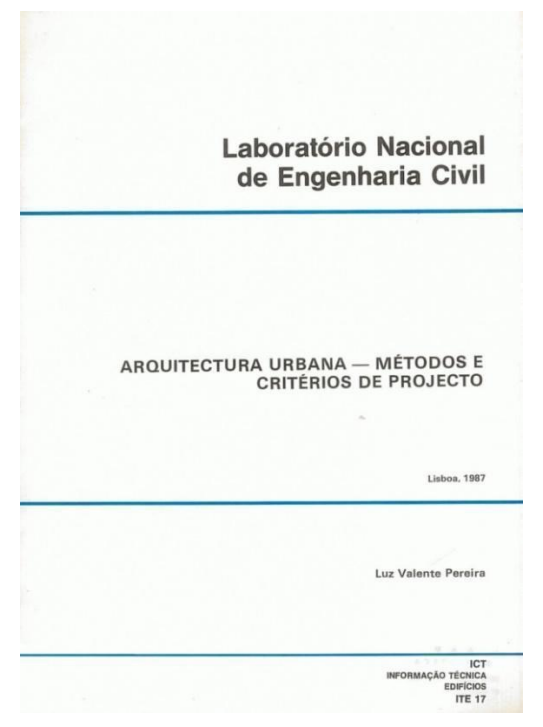

Figure 8 .

Pages of the book Urban Rehabilitation - The Reading of the Urban Image, (a) about the reading approach to the area and (b) the composition and morpho-typological structure of urban spaces in the «Plan to Safeguard the Old Centre of Sacavém» (Valente-Pereira, n.d., 25, 68).

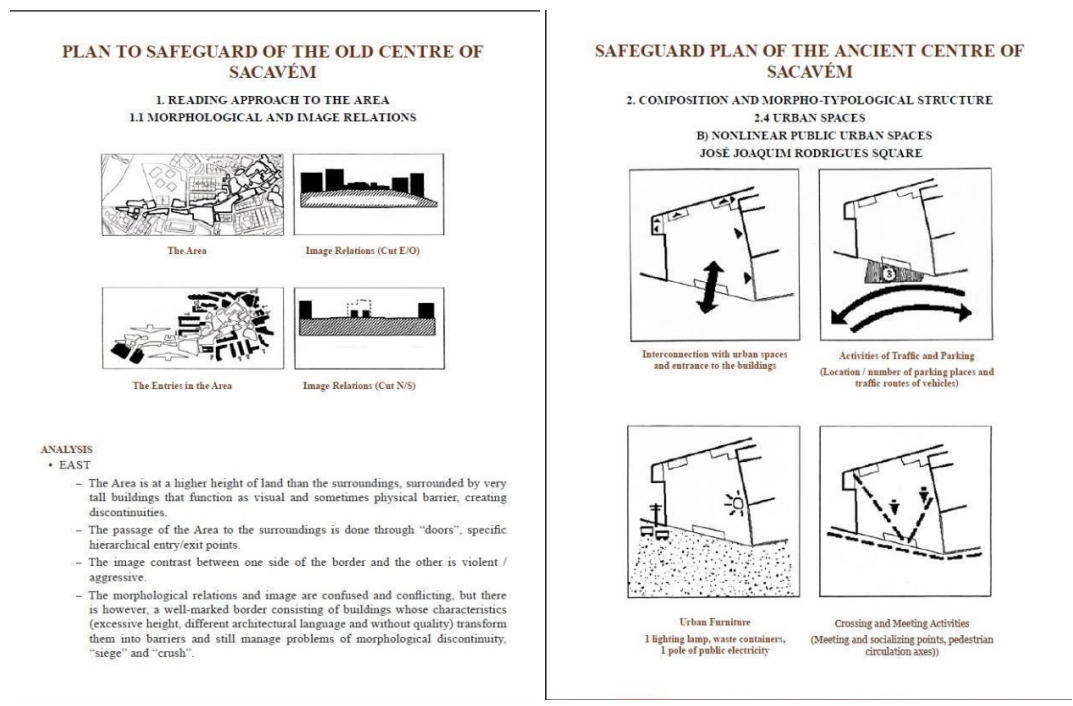




\section{Some final notes}

The wealth of Luz Valente-Pereira's path, as well as the wide range of critical questions and perspectives through which it can be approached, are far from being resolved in this article. As mentioned earlier, we have tried to contribute to a beginning. Nonetheless, as final notes, we would like to propose a few reflections that result both from the biographical work developed and the prospective questions that have emerged.

The objects of study that she has chosen throughout her career - from the house to the city - and the concerns that have moved her can be placed into a wider Portuguese context of reflection and research in Architecture. Despite finding a place in her time, and considering the extensive and relevant scientific production carried out in the LNEC for five decades that were presented above, it is clear that she is rarely referenced or cited in scientific and academic architectural works. Her absence is also evident in historical records of $20^{\text {th }}$ century Portuguese Architecture.

Oral narratives emerge as an important source of information and problematization for the construction of the History of Women. For example, the analysis of the interview has allowed us to realize that the autonomy and independence economic as well - that was imparted to Luz Valente-Pereira from early on marked her personal and professional lives. As a young woman during the Portuguese dictatorship, she studied at the university, got a degree in Architecture and traveled abroad by herself. Upon her return, she had various professional experiences before finding out what truly motivated her. It is important to underline, however, that if in the interview she provided an exhaustive chronological list of her professional achievements, there were very few comments on her personal life or the key moments that characterized the lives of so many women of her generation. What one decides to talk about or not is also an element that invites reflection.

Moreover, from a reflection on the studied material, an interesting paradox emerged, to a certain extent linked to the previous point. During the interview, Luz Valente-Pereira did not mention situations of obvious discrimination, and certainly not connected to the fact that she is a woman. ${ }^{25}$ In a few moments, she referred her non-confrontational character as an explanation for any attempts to silence her. In certain occasions she chose to act outside of the LNEC, as a way of obtaining international appreciation and visibility for her work. For example, she funded the Brazilian conferences herself, which took place during her holidays, as well as the belated translation of some of her works into English. Even though we

Another important question needs to be developed further: did her privilege as a white, graduated, middle-class woman, living in the country's capital, educated for professional and personal autonomy, hindered an awareness of the gender discrimination to which she might have been subjected? This reflection is vital and pertains to every woman architect, given the traditionally elitist character of the profession. 
can sense some acceptance of the fact that her work was not recognized by her peers, the aforementioned reactions arise as acts of discreet rebellion against an imposed silence. In a way, the strategy that she chose to overcome a professional reality that was felt as disadvantageous led to a greater personal investment, aligned with her idea of independence.

The visibility of Luz Valente-Pereira's professional path demands a critical reflection on the mechanisms of omission and silencing of History. Subsequent studies should focus on her life and work, but also on the full, complex, contextual and diverse History of Women in Architecture in Portugal. Luz Valente-Pereira was probably the first woman architect in Portugal to devote herself exclusively to a career in research. She is part of an extensive group of architects who, working outside architectural studios and shunning the limelight, were essential in the construction of architectural knowledge, even though they are not part of Portuguese historical narratives yet. As mentioned before, this biographical article is a contribution to future critical works, both produced within History, or coming from complementary scientific perspectives, such as urban studies, sociology or the theory of architecture. Awarding her visibility also means awarding visibility to research work as a relevant professional practice in the construction of Portuguese architectural culture, focusing on something other than the project practice. We are still yet to understand the true repercussion of these studies and proposals residential, urban and territorial - in the improvement of the conditions of spatial justice, as the materialization of democracy and full citizenship in Portugal.

\section{Acknowledgements}

This research and the translation of this article was supported by Portuguese national funds through Fundação para a Ciência e a Tecnologia (FCT), under project PTDC / ART-DAQ/32388/2017.

\section{References}

Antunes, Lia Gil. 2016. «Questões de género em arquitetura. História(s), espaço(s) e experiências profissionais e arquitetónicas». ex aequo 33: 67-81. DOI: https:/ / doi.org/ 10.22 355/ exaequo.2016.33.05.

Bandeirinha, José António. 2011. O Processo SAAL e a Arquitectura no 25 de Abril de 1974. Reprint. Coimbra: Imprensa da Universidade de Coimbra. DOI: https://doi.org/ 10.14195/978-989-26-1265-2.

Carvalho, Filipa Reis. 2020. Maria José Marques da Silva. Uma arquiteta pioneira em Portugal. Master Thesis in Architecture, Department of Architecture, University of Coimbra.

Carvalho, Mariana Marques Ramos Rodrigues. 2012. Investigação em Arquitectura: O Contributo de Nuno Portas no LNEC: 1963-1974. Master Thesis in Architecture, Department of Architecture, University of Coimbra. 
Freitas, Maria João, Marluci Menezes, and António Baptista Coelho. 1996. «Contributos Sociológicos para a Análise e Definição de Qualidade Residencial». Paper presented at the III Portuguese Congress of Sociology: Práticas e Processos de Mudança Social, Lisbon, February 7-9. Available at https://aps.pt/wp-content/uploads/2017/08/ DPR492abea138282_1.pdf.

Jornal do Brasil. 1972. "Arquiteta portuguesa diz que não existe receita para construção de cidade», 1. ${ }^{\circ}$ Caderno - Urbanismo, 19. September 24, Year LXXXII, 157th edition. Available at http: / / memoria.bn.br/DocReader/030015_09/67772.

LNEC- Laboratório Nacional de Engenharia Civil. 2011. Núcleo de Arquitectura e Urbanismo (NAU) do LNEC - Áreas de intervenção. Lisbon: LNEC. Available at http:/ / repositorio. lnec.pt:8080/jspui / handle/123456789/1001862.

Marat-Mendes, Teresa, Patrícia Bento d'Almeida, and João Cunha Borges. 2019. «Mapeamento de Conceitos e Paradigmas para a Sustentabilidade». Researchers meeting with Science and Technology presented at the Ciência '19, Lisbon Congress Centre, July 8.

Milheiro, Ana Vaz, and Filipa Fiúza. 2020. «Women Architects in Portugal: Working in Colonial Africa before the Carnation Revolution (1950-1974)». Arts 9 (3): 86. DOI: https: / / doi.org/10.3390/arts9030086

Pedrosa, Patrícia Santos. 2010. Habitar em Portugal nos Anos 1960: Ruptura e Antecedentes. Um caminho pelo interior do discurso. PhD Thesis, ETSAB - Barcelona School of Architecture. 2015. «Women architects in Portugal. A long and winding road». In ArquitectAs. Redefiniendo la Professión, edited by Núria Álvarez Lombardero, 99-112. Sevilla: Recolectores Urbanos.

. 2019. «The W@ARCH.PT as an Ongoing Feminist Research Project in Architecture: Contextualizing Initial Reflections». The Plan Journal 4 (2): 4/2/1-4/2/12. DOI: https:/ / doi.org/10.15274/tpj.2019.04.02.7

Pérez-Moreno, Lucía and Patrícia Santos Pedrosa. 2020. «Women Architects on the Road to an Egalitarian Profession - The Portuguese and Spanish Cases». Arts 9 (1): 40. DOI: https: / / doi.org/10.3390/arts9010040.

Pimentel, Irene Flunser. 2011. A cada um o seu lugar, a política feminina do Estado Novo. Lisbon: Temas e Debates and Círculo de Leitores.

Pimentel, Irene Flunser, and Helena Pereira de Melo. 2015. Mulheres Portuguesas. História de Vida e dos Direitos das Mulheres num Mundo em Mudança. Lisbon: Clube do Autor.

Portas, Nuno. 1964. Estudos das Funções e da Exigência de Área da Habitação. Volume I - Necessidades familiares e áreas da habitação. Análise de exigências por funções, da habitação. Lisbon: LNEC.

Portas, Nuno (coord). 2003-2011. Políticas Urbanas. 2 Vol. Lisbon: Fundação Calouste Gulbenkian.

Portas, Nuno, and Luz Valente-Pereira. 1967. Inquérito piloto sobre necessidades familiares em matéria de habitação: 2o. relatório. Vol. 2. Lisbon: LNEC.

Roxo, Joana. 2016. A Senhora Arquiteto - Maria José Estanco. A cidade, o Porto e a arte: Residências artísticas em Sines. Master Thesis in Architecture, ISCTE-UL, Lisbon.

Tavares, Manuela. 2011. Feminismos. Percursos e Desafios (1947-2007). Lisbon: Leya.

Valente-Pereira, Luz. 1968. «As casas que se constroem». Diário de Lisboa, no. 16393, Year 48, August 8, 3rd edition, Suplemento literário, 4-6. Lisbon: Fundação Mário Soares/ DRR - Documentos Ruella Ramos. Available at http: / / casacomum.org/cc/visualiza dor?pasta $=06590.128 .22590 \# ! 24$

1971a. Organização e qualidade do espaço urbano: cidade: conceitos e definições. Lisbon: LNEC. 
. 1971b. Organização e qualidade do espaço urbano: modelo de análise dinâmica do sistema urbano à escala de zona urbana. Lisbon: LNEC.

. 1971c. Organização e qualidade do espaço urbano: inquérito piloto à utilização da cidade: preparação do inquérito e colecta de dados. Vol. 1. Lisbon: LNEC.

. 1971d. Organização e qualidade do espaço urbano: inquérito piloto à utilização da cidade: método, plano de análise e análise de dados. Vol. 2. Lisbon: LNEC.

. 1973. «Modelo do Sistema Urbano à Escala de Zona Urbana». Análise Social X (37):

5-49. JSTOR: www.jstor.org/stable/41008101.

. 1977a. Inquérito à habitação urbana: o uso e o espaço dos fogos. Vol. 1. Lisbon: LNEC.

. 1977b. Inquérito à habitação urbana: o uso e o espaço dos fogos. Vol. 2. Lisbon: LNEC.

1977c. Inquérito à habitação urbana: o uso e o espaço dos fogos. Vol. 3. Lisbon: LNEC.

. 1981a. «O espaço urbano como objecto arquitectónico - consequências a nível do planeamento, do projecto e das práticas profissionais». In $2 .^{\circ}$ Congresso da Associação dos Arquitectos Portugueses: Os Arquitectos e o Ordenamento do Território, edited by Associação dos Arquitectos Portugueses, 121-124. 1st ed. Lisbon: AAP.

. 1981b. A estrutura da informação de base local no contex to da descentralização e regionalização. Lisbon: CIUR.

. 1982. Definição da forma urbana no planeamento físico. Scientific work M 570. Memories. Lisbon: LNEC.

1983a. Forma urbana no planeamento físico. Lisbon: LNEC.

1983b. Os equipamentos colectivos e a transformação urbano-rural. Scientific work M 586.

Memories. Lisbon: LNEC.

. 1984a. Metodologia do planeamento municipal: bases para a renovação da metodologia do planeamento. Vol.1. Lisbon: LNEC.

.1984b. Metodologia do planeamento municipal: os estudos sumários do planeamento: política e estratégia da acção municipal. Vol. 2. Lisbon: LNEC.

. 1986a. Planeamento municipal e exercício da acção política local. Technical information ITE 10. Technical building information. Lisbon: LNEC.

. 1986b. Método de apoio técnico à acção de desenvolvimento sócio-urbanístico de uma área urbana de intervenção: metodologia, vol. 1. Technical information ITE 13. Technical building information. Lisbon: LNEC.

. 1987a. Arquitectura urbana - Métodos e critérios de projecto. Lisbon: LNEC.

. 1987b. Reabilitar o urbano ou como restituir a cidade à estima pública. Technical information ITE 16. Technical building information. Lisbon: LNEC.

. 1987c. Método de apoio técnico à acção de desenvolvimento sócio-urbanístico de áreas urbanas de intervenção: Planeamento e programação das intervenções a curto prazo, vol. 2. Technical information ITE 13. Technical building information. Lisbon: LNEC.

1990. A utilização da cidade: um estudo sobre a cidade de Lisboa. Scientific information INCGURPLAM 2. Municipal planning scientific information. Lisbon: LNEC.

. 1991. Metodologia de planeamento da reabilitação de áreas urbanas. Scientific information INCGURPLAM 4. Municipal planning scientific information. Lisbon: LNEC.

.1994. A leitura da imagem de uma área urbana como preparação para o planeamento-acção da sua reabilitação. Scientific information INCGURPLAM 12. Municipal planning scientific information. Lisbon: LNEC.

. 2018. «Um Testemunho de Vida-Mulher, Arquitecta, Investigadora / A Life TestimonyWoman, Architect, Researcher». In Arquitectas: Modo(s) de (R)Existir. Reflexões a partir de um Ciclo de Conversas, edited by Joana Pestana Lages, Patrícia Santos Pedrosa, and Lia Gil Antunes, 38-43. Lisbon: Mulheres na Arquitectura. 
. 2019. Interview with Luz Valente-Pereira in the scope of the research project W@ ARCH.PT - Women Architects in Portugal: Building Visibility, 1942-1986, Alenquer. Interviewed by Patrícia Santos Pedrosa and Lia Gil Antunes. Video and audio. December 20 .

. n.d. Urban Rehabilitation-The Reading of the Urban Image. Self-published. Available at https: / / issuu.com/luzvalente-pereiraurbanplanning/docs/the_reading_of_the_ urban_image_.

Valente-Pereira, Luz, and Maria Amélia B. Corrêa Gago. 1972. Inquérito à habitação urbana: pesquisa de campo. Lisbon: LNEC.

. 1974a. Inquérito à habitação urbana: análise e interpretação das actividades na habitação e a sua relação com os espaços da casa. Lisbon: LNEC.

. 1974b. Inquérito à habitação urbana: características da amostra. Lisbon: LNEC.

. 1974c. O Uso do espaço na habitação. Lisbon: LNEC. Disponível em https: / / www.aca demia.edu/7720855/O_USO_DO_ESPAÇO_NA_HABITAÇÃO.

Patrícia Santos Pedrosa. Feminist, architect, activist, professor, researcher, and mother. Researcher at the Interdisciplinary Centre for Gender Studies, University of Lisbon. Invited Assistant Professor at the University of Beira Interior. Co-founder and president of Women in Architecture (Portugal). Researcher in charge of the project Women Architects in Portugal: Building Visibility 2018-2021. Main areas of research: Architecture and Gender; Cities and Gender; Feminist Urbanism; Portuguese Architecture History ( $20^{\text {th }}$ century).

Endereço eletrónico: pat.pedrosa@gmail.com

Lia Gil Antunes. Architect, researcher, feminist, and co-founder of Mulheres na Arquitectura association. PhD candidate in darq-UCoimbra about women - architects, other professionals, and inhabitants - of the SAAL process, and research fellow in the project W@ARCH.PT - Women Architects in Portugal: building visibility, 1942-1986 (CIEG / ISCSP-ULisboa). Areas of interest: Feminist and gender studies; History and Theory of Architecture; Right to Housing and Right to the City; Citizen participation. Endereço eletrónico: liapantunes@gmail.com 



\section{Recensões}





\title{
Gender Studies and the New Academic Governance. Global Challenges, Glocal Dynamics and Local Impacts, edited by Heike Kahlert. Wiesbaden, Springer, 2018, 289 pp.
}

\author{
Júlia Garraio* \\ Centro de Estudos Sociais da Universidade de Coimbra
}

Gender Studies and the New Academic Governance analisa como, em diferentes contextos sociogeográficos, o neoliberalismo, enquanto ideologia determinante na gestão das universidades atuais, se repercutiu nos estudos de género e nas relações desta área científica com a comunidade. $\mathrm{O}$ volume entende o neoliberalismo como teoria económica e movimento de reforma social vitoriosos na ordem mundial pós-1989, que se alastrou globalmente, moldando decisivamente as sociedades contemporâneas, nomeadamente os processos de produção e disseminação de conhecimento e a maneira como a universidade é atualmente entendida como espaço onde se fornecem competências que os/as estudantes posteriormente poderão vender/rentabilizar como trabalho. O objetivo do volume é assim analisar as repercussões da hegemonia desta visão mercantilista do conhecimento na implementação e disseminação de estudos de género na academia, abordando, entre outros, o papel desta área na atual transformação da universidade, as implicações do modelo de financiamento científico e nas aspirações profissionais e carreiras de investigadores/as da área, sem descuidar as perceções sociais desse tipo de investigação.

O volume encontra-se dividido em três secções temáticas, contando no total com onze estudos de caso, com distintas abordagens metodológicas e uma grande variedade de fontes de análise. A primeira parte (Interventions: Gender, Gender Studies and Feminism) é composta por três estudos sobre as repercussões das dinâmicas neoliberais nos estudos feministas e de género em diferentes contextos académicos e científicos. Louise Morley analisa como o neoliberalismo tende a reforçar o domínio masculino ao validar áreas e atividades científicas nas quais têm dominado tradicionalmente certos tipos de homem. Kadri Aavik e Raili Marling argumentam que a mercantilização das universidades na Estónia contou com a acomodação e cumplicidade de investigadoras feministas. Defendem a revitaliza- 
ção do sindicalismo e da luta coletiva, bem como a adoção de perspetivas interseccionais na investigação. A partir do contexto da África do Sul, Desiree Lewis analisa as repercussões da investigação neoliberal na reprodução de relações de poder Norte-Sul. Segundo a autora, torna-se imperativo investir em iniciativas e perspetivas de feminismo transnacional que, sensíveis às realidades fora da academia, desafiem essas mesmas relações.

A segunda parte (Interactions: Gender Research, Academic Feminism and Society) conta com quatro estudos sobre as interações e colaborações entre investigação e sociedade. Pia Vuolanto debruça-se sobre uma acesa controvérsia que teve lugar na Noruega em 2010-11 em torno da relação entre os estudos de género e a sociedade. Amélia Augusto, Catarina Sales Oliveira, Emília Araújo e Carla Cerqueira analisam a relação entre estudos de género e políticas para a igualdade de género no contexto da introdução de modelos de gestão neoliberal na universidade portuguesa. As autoras identificam as repercussões da gestão neoliberal na produção de conhecimento (aumento da produtividade que obedece a critérios de avaliação interna, individualismo, precariedade laboral, excesso de trabalho) e notam que esta realidade pode ser concomitante com uma certa invisibilização social da investigação. Consideram, todavia, que os estudos de género devem e podem reclamar o seu potencial crítico e transformador. Sigrid Schmitz estuda a influência de um projeto científico em políticas com vista à integração de questões de género na produção científica. Cristiano Rodrigues e Mariana Prandini Assis argumentam que a produção feminista dominante no Brasil deverá confrontar as exclusões com as quais pactua, e empenhar-se na inclusão radical de outras perspetivas, como o conhecimento produzido pelos feminismos negros e por abordagens intersecionais, a fim de garantir a sua relevância social.

Aterceira parte(Institutionalisations: Gender Studies'Epistemicand Organisational Statuses in the Academy) é composta por quatro estudos sobre as condições, os modelos e as estratégias de institucionalização dos estudos de género na academia. Remetendo para diferentes contextos socio-históricos, os quatro capítulos convergem ao apontarem para a posição ambivalente dos estudos de género no modelo de gestão neoliberal: por um lado, verifica-se um apoio formal a iniciativas integrantes de questões de género, mas, por outro, nota-se a falta de reconhecimento científico pela área e a tendência para condições materiais de investigação precárias. Maria do Mar Pereira oferece um panorama dos processos de institucionalização dos estudos sobre mulheres, género e feministas ao longo de várias décadas, apontando para as discrepâncias entre os discursos institucionais de reconhecimento e a desqualificação da área em conversas informais. Farinaz Fassa e Sabine Kradolfer analisam a articulação dos estudos de género com as exigências sociais a partir de um contexto da Suíça francófona. Heike Kahlert debruça-se sobre as universidades alemãs para analisar as relações entre os estudos de género e as políticas promotoras da igualdade de género. Por fim, Blanka Nyklová estuda as interseções entre o posicionamento geográfico e a posição dos estudos de género 
como disciplina na República Checa, argumentando que o crescimento da área no contexto do neoliberalismo e da integração europeia não deixou de ter algumas dimensões problemáticas, tais como as alegações de irrelevância local, em ressonância com certos discursos antifeministas pós-1989.

Lidos no seu conjunto, os vários capítulos sinalizam que o neoliberalismo criou pressões semelhantes sobre os estudos de género limitadoras do potencial emancipatório desta área; no entanto, a leitura comparativa dos mesmos capítulos expõe as especificidades de cada espaço analisado, com a emergência de diferentes dinâmicas criadas pelas interações entre processos globais e necessidades/ pressões locais. O volume não se limita, porém, a analisar os problemas e os desafios que se colocam aos estudos de género em contextos de mercantilização do conhecimento e precarização laboral. Os/As autores/as fazem também sugestões sobre como resistir ao pulsar individualista-mercantilista e resgatar o potencial emancipatório do feminismo enquanto espaço de transformação social (veja-se nesse sentido, por exemplo, os capítulos sobre a Estónia e o Brasil). Trata-se assim de uma obra de grande valor para percebermos o estado atual dos estudos de género. É certo que, apesar de abranger espaços com diferentes historiais sociopolíticos e formas de introdução do neoliberalismo, o volume caracteriza-se por um inequívoco foco europeu, já que a larga maioria dos contributos incide sobre geografias da Europa do Norte, do Sul, Ocidental e de Leste. Tal deve ser visto, todavia, como um estímulo ao alargamento do campo de investigação a outras zonas do globo, cujas realidades e modelos de integração de estudos de género nos programas académicos poderão complexificar, questionar e alargar os conhecimentos sobre o tema.

A necessidade de alargar o campo de análise a outras realidades geográficas, bem como a pertinência de revisitar os espaços analisados no volume, também se prende com os desenvolvimentos sociais que marcaram os últimos dois anos em termos de perceção social dos estudos de género. 2018, data de publicação do volume, corresponde a um marco importante nos ataques à disciplina. Como sabemos, trata-se do ano em que a Central European University se viu impelida a transferir os seus programas em estudos género para Viena devido a políticas hostis do governo húngaro. Várias vozes conceituadas desta área de investigação têm vindo a advogar a necessidade de se analisar criticamente os ataques à «ideologia de género» também no contexto das reações às inseguranças e desigualdades associadas à globalização neoliberal e das ameaças atuais ao modelo de democracia liberal. Elzbieta Korolczuk e Agnieszka Graff interpretam o discurso anti-género da década de 2010 precisamente como uma nova linguagem conservadora correlacionada com os efeitos da crise económica internacional de 2008. ${ }^{1}$ Ora, é também aqui que o volume em análise ganha a maior pertinência. Por um lado, apresenta dados

Korolczuk, Elzbieta \& Agnieszka Graff. 2018. Gender as «ebola from Brussels»: The anticolonial frame and the rise of illiberal populism. Signs 43(4), 797-821. 
e reflexões que nos ajudam a perceber como se chegou ao estado atual em que os estudos de género são confrontados com uma necessidade crescente de justificarem o seu valor e de se defenderem de atitudes hostis e ameaças de desinvestimento. Por outro, aponta caminhos com vista à capacidade de os feminismos e os estudos de género reclamarem a sua pertinência social. Por fim, sinaliza a necessidade de mais trabalho de investigação sobre os ataques aos estudos de género a partir da análise de questões económicas e das implicações da promoção de políticas de igualdade de género em contextos de precarização laboral e afirmação da ideologia neoliberal.

* Recensão realizada no âmbito do projeto DeCode/M (Des)Codificar Masculinidades: para uma melhor compreensão do papel dos media na construção de perceções de masculinidades em Portugal», financiado pela FCT (ref. PTDC/COM-CSS/31740/ 2017).

The Positioning and Making of Female Professors. Pushing Career Advancement Open, edited by Rowena Murray \& Denise Mifsud. Palgrave Studies in Gender and Education. Palgrave Macmillan, 2019, 241 pp.

Sofia Castanheira Pais

Centro de Investigação e Intervenção Educativas, FPCE, Universidade do Porto

The Positioning and Making of Female Professors. Pushing Career Advancement Open, editado por Rowena Murray e Denise Mifsud é uma recente publicação da Palgrave Macmillan e inclui textos de onze autoras que partilham as suas trajetórias enquanto investigadoras e docentes no Ensino Superior. A forma como constroem as suas narrativas denota, de forma particular e significativa, como a Academia é, ainda, lugar de desafios acrescidos para as mulheres. É sobre esses desafios, contados no feminino, que este texto versa.

Da autoria de Denise Mifsud, a primeira narrativa põe em destaque a hegemonia masculina no Ensino Superior e sublinha as dificuldades que daí advêm para pensar a igualdade e o pluralismo. Situa o texto na era do neoliberalismo, pautada pela precariedade, e onde, desde logo, as oportunidades de iniciação à carreira científica são colocadas às mulheres de forma especialmente difícil. A autora refere-se às Universidades como «organizações de género inseridas numa hierarquia de género» (Britton, 2017, 5 in Mifsud, 2019, 5), nas quais os lugares de poder são, tradicionalmente, ocupados por homens. Embora não reduza esta hierarquia a lugares de topo perpetuados por homens, Mifsud explica que haver 
menos mulheres em posições seniores constitui em si mesmo uma barreira a que outras mulheres alcancem níveis superiores de poder nas instituições.

É, precisamente, para afrontar, disruptivamente, este discurso masculino hegemónico que Isabel Menezes sugere o uso do humor, no seu texto. A propósito da sua experiência na Universidade, reflete sobre a sua carreira propondo um olhar crítico, situado e assumidamente feminista sobre a construção do género na Academia. Dá conta da entrada das mulheres no Ensino Superior, no contexto de transição da ditadura para a democracia, referindo-se muito claramente à dimensão política que perpassa o (não-)reconhecimento dos direitos das mulheres e os significados das suas lutas ao longo do tempo, em Portugal. Reclama a urgência de um confronto de poderes, tão coletivo quanto honesto, onde as boas intenções anunciadas não resvalem para atitudes sexistas, e onde a discussão não se limite a enfrentar os poderes de outros, mas também os nossos.

Nesta linha, o texto de Caroline Gatrell reforça a importância da dimensão colaborativa nas trajetórias das mulheres na Universidade. Mais, põe em foco as implicações da maternidade e evidencia que a ausência de uma cultura dominante contada no feminino torna a Academia um contexto fértil para contradições e desajustes. Critica o princípio assente na expectativa de que ser mulher significa, inquestionavelmente, fazer escolhas (como se a questão se colocasse entre ser «uma boa mãe» ou «uma académica de sucesso»!).

Catherine Mazak também se debruça sobre percursos em torno da maternidade, assumindo que é, precisamente, o facto de ser mãe que torna a existência na Academia uma experiência de resistência. A gestão da vida académica antecipada pelo aproximar do nascimento de bebés - incluindo a redação de livros, artigos científicos e a lecionação de aulas, ou, a fantasia de que a licença de maternidade deve ser (simultaneamente) tempo de produção científica - é reveladora de uma exigência nem sempre compreendida no contexto académico. Será, como mostra Mazak, uma questão de in/visibilidade ou porventura, tão somente, resultado de uma Academia incapaz de incorporar essa narrativa.

É sobre a inscrição de si própria na carreira académica que Rowena Murray fala. Não se tratando de «analisar contextos discriminatórios» (p. 89), a autora mostra como a discriminação de género influenciou a sua autoconfiança e o modo de estar e de ser na Universidade. A certeza de que para sobreviver teria que publicar, fez com que criasse grupos de escrita (e um Social Writing Framework) que, mais do que uma receita para o sucesso, se tornou uma estratégia de re/existência. A experiência de uma rede capaz de dar suporte, acolher discussões, fomentar reflexões, onde o foco é essencial e a escrita é entendida como uma competência académica prioritária, constitui parte da sua agência na Academia.

Da investigação pós-doutoral a uma posição enquanto docente, é feito o caminho de Jackie Potter. É sobre fluidez que trata o seu texto e sobre como o seu sentido de identidade enquanto académica se foi construindo ao longo das transições que pautaram a sua experiência na Universidade, desde a maternidade, ao 
desempenho de diferentes papeis, à diversidade nos modos de colaboração com colegas. Se esta fluidez é razão de mudança na perceção de si, Potter assume que dimensões houve que se mantiveram imutáveis: os seus valores, tão nucleares na condução da sua ambição académica e na tomada de decisões importantes na sua carreira.

Resiliência é palavra de ordem no texto de Sarah Skerratt e é com base na sua própria experiência de abuso e de humilhação enquanto criança que discorre sobre a decisão de, aos 22 anos, se tornar professora. Foi aos 50 anos que alcançou esse objetivo e é, desde então, desse lugar privilegiado que toma a palavra para reclamar direitos de outros/as, nem sempre ouvidos/as. É dessa resiliência, onde Skerratt encontra a liberdade de e a liberdade para (Pratchett, 2004), que a sua narrativa fala.

É a partir de Osaka (Japão) que a britânica Beverley Anne Yamamoto conta como se tornou professora, num contexto onde as desigualdades de género, particularmente ao nível da não-representação de mulheres em universidades de excelência, ainda são gritantes. Da posição de docente, conta como passou de facilitadora a agitadora e inclui na sua reflexão a importância do corpo «disciplinado, mas disruptivo das mulheres poderosas» (Blackmore, 1999). Faz da aparência um statement e reconhece a importância da vida fora da Academia para encarar com leveza a sua jornada académica.

Rejeitando a ideia de uma metodologia monolítica, Devorah Kalekin-Fishman retrata, através da auto-etnografia, o que considera serem os seus maiores desafios na Universidade. Alude à circulação do poder enquanto estrutura multidimensional sem rosto, ao significado das normas e ao reconhecimento do capital académico, explicando como os converteu em seu favor.

Moira Lafferty sublinha que trazer e inspirar uma geração de mulheres jovens na Academia é o ingrediente-chave para tornar possível uma outra discussão sobre o que deve e o que pode ser este contexto. Criar uma cultura de suporte nas primeiras etapas da carreira, assim como reconhecer que a prática académica e profissional é diversa, constituem também dimensões nucleares. Como estas, a promoção de um ambiente colegial e colaborativo, dentro e fora das instituições-base de que fazem parte estas mulheres e o suporte ao nível da progressão a lugares na Academia são igualmente vetores essenciais que Lafferty explora no seu texto.

É sobre indisciplina e crises existenciais que a narrativa de Inger Mewburn versa. A autora explana sobre momentos de transição na carreira na Academia australiana e sobre como a experiência de ter um papel de apoio no processo de ensino e na aprendizagem a colocou do lado frágil (porque desvalorizado) da Universidade. E é a partir deste lado que desafia as lógicas instaladas e que reclama a abertura a outros espaços para as mulheres.

Finalmente, Denise Mifsud conclui a obra com uma leitura sobre as formas de superação encontradas pelas autoras neste processo de se tornarem parte da Academia. Transversalmente, Mifsud encontra nas suas narrativas a evidência de que foram relegadas para posições pautadas pela desigualdade de género, em que 
tiveram que confrontar-se com estruturas de poder e diversas formas de discriminação. Ainda assim, acentua como foram bem-sucedidas fazendo da resistência aos desempenhos esperados uma estratégia a seu favor. Da experiência de organização do livro, sublinha os desafios que assumiu enquanto narradora, finalizando a obra com uma interessante conversa com Foucault, (também) assumidamente concordante com a necessidade de mostrar que estas trajetórias de sucesso desveladas não são óbvias como as pessoas possam pensar.

Corroborando a leitura de Mifsud, em cada narrativa se discorre sobre o processo, muito além do que se dedica a perceber do resultado. Globalmente, os textos dão conta de percursos que reclamam a visibilidade e o reconhecimento das mulheres na Academia, admitindo, explicitamente, que as especificidades da experiência no feminino são, de facto, singulares, diversas e essenciais. Mais, partem do princípio de que a sensibilidade para lidar com os desafios não retira nem exclui; pelo contrário, acrescenta e amplifica - afinal, «ser tenaz faz parte de ser mulher» (Menezes, 2019, 33) - o conhecimento, a produção científica, as relações humanas e institucionais e a Academia. E é, inevitavelmente, a experiência particular de ser mulher e a materialização daquilo que envolve, quer seja através da maternidade, quer seja através da forma de ler e de traduzir o mundo ou de lhe resistir, que torna a sua presença na Academia lugar de desafio e de afronta ao problema.

Como sugere Alexis Shotwell $(2016,204)$ :

rejeitar a pureza é o início e a compreensão da nossa implicação neste mundo comprometido, é reconhecer as várias injustiças que assolam diariamente as nossas vidas, e a partir desse entendimento, é agir em conformidade com o nosso desejo de que o mundo deixe de ser assim. (...) Nós não podemos prever o que pode emergir das práticas individuais e coletivas de ficar com o problema, exceto assumir que tê-lo nas mãos é tornar possível um outro mundo, ainda que imperfeito e impuro, e outro e mais outro depois desse.

Importa, por isso, muito justamente, desocultar a bravura e a invisibilidade das mulheres tão marcada em tantos domínios, ao longo do tempo (veja-se Joana d'Arc nas lutas de França ${ }^{2}$, as Carquejeiras do Porto ${ }^{3}$, etc.) e questionar o conjunto de representações que repousam, desde os contos infantis ${ }^{4}$ até aos dias de hoje, sobre elas e os seus desempenhos. Tal implica romper com a expectativa de que o espaço de atuação das mulheres deve configurar-se por referência aos interesses

Nolan, Jeannette C. 1980. Joana D' Arc. $6^{a}$ Edição. Porto: Civilização.

LIGA PORTUGUESA DE PROFILAXIA SOCIAL. 1951. O Problema das Carquejeiras do Porto e como a Liga Portuguesa de Profilaxia Social tem procurado resolvê-lo. Porto: Imprensa Social.

4 Brocklehurst, Ruth \& Gillian Doherty. 2010. Usborne illustrated Grimms' Fairy Tales. London: Usborne. Sobre a representação de mulher como alguém frágil, indefesa, relegada para o papel de cuidadora, à espera de ser libertada por uma figura masculina presente neste e em diversos contos. 
materiais e simbólicos da linhagem (dos homens) (Bourdieu, 1999), impondo-se uma determinada visão do mundo (Adichie, 2012). Mais, significa compreender que, em diversos casos, acarretando perdas pessoais, constrangimentos familiares adicionais, embates profissionais, etc., a democratização da esfera privada e o papel central que nela ocupa a figura feminina precisam de ser repensados, para que «as mulheres [que] desempenharam de longe o papel principal, [não vejam] no final os benefícios alcançados [...], como na esfera pública, abertos a todos» (Giddens, 2001, 129). É, assim, altura de invocar as dimensões ética e política ao invés de acolher o princípio da neutralidade (Vieira, Alvarez \& Ferro, 2017), visibilizando as trajetórias e as estratégias destas mulheres, as suas redes de suporte, os seus apelos a um reconhecimento de que é possível perspetivar a história de maneira diferente. E isso requer que sinalizemos os ganhos que advêm da entrada destas (e de tantas outras!) mulheres na Academia e ressaltemos que o seu sucesso na Universidade não é e não pode ser uma escolha; é um direito. Ainda que olhar para este livro seja ver trajetórias pessoais no feminino, perscrutar as narrativas destas mulheres significa assumir, indubitavelmente, que a história que aqui se conta é sobre todas e sobre a narrativa que um dia fará, como elas e todas nós, parte da Academia.

\section{Referências}

Blackmore, Jill. 1999. Troubling women: Feminism, leardership and educational change (Feminist Educational Thinking). Buckingham: Open University Press.

Bourdieu, Pierre. 1999. A Dominação Masculina. Oeiras: Celta Editora.

Adichie, Chimamanda Ngozi. 2012. A Coisa à volta do teu Pescoço. Alfragide: D. Quixote.

Giddens, Anthony. 2001. As Transformações da Intimidade. Sexualidade, Amor e Erotismo nas Sociedades Modernas. Oeiras: Celta

Pratchett, Lawrence. 2004. «Local autonomy, local democracy and the 'new localism'». Political Studies 52(2), 358-375.

Shotwell, Alexis. 2016. Against Purity. Living Ethically in Compromised Times. Minneapolis, London: University of Minnesota Press.

Vieira, Cristina C., Maria Teresa Alvarez, \& Maria Jorge Ferro. 2017. «Questões de género e cidadania: reflexões breves sobre o poder emancipatório da educação». In L. Alcoforado, M. R. Barbosa, \& D. A. Barreto (Eds.), Diálogos Freireanos: a educação e formação de jovens e adultos em Portugal e no Brasil (pp. 701-716). Coimbra, IUC e Recife, Universidade Federal de Pernambuco. 
RECENSÕES

Revolución feminista y políticas de lo común frente a la extrema derecha, edited by María Eugenia Rodríguez Palop. Barcelona: Icaria, 2019, 151 pp.

\author{
Jana Soler Libran \\ Universidad Autónoma de Barcelona, Facultad de Filosofía y Letras
}

María Eugenia Rodríguez Palop, profesora de derechos humanos, filosofía política y del derecho, y actualmente eurodiputada por el grupo parlamentario Podemos, da cuenta en su último libro Revolución Feminista y políticas de lo común frente a la extrema derecha de dos respuestas políticas antagónicas que han tenido lugar a raíz de las crisis sociales de la última década: el auge de la extrema derecha y el estallido de la revolución feminista. Circunscribiendo el análisis en el marco de los estados liberales del norte global y especialmente centrándose en las particularidades del escenario político español, Palop pone en valor el feminismo y la política de lo común, considerándolos el antídoto frente a una nueva derecha autoritaria anclada en el nacionalismo y el uso institucional de la violencia. Se trata, para Palop, de reivindicar una política feminista que, oponiéndose a la "política de los muros» con la «política de los cuerpos» (p. 6), construya una forma de vida en común basada en la centralidad de los cuidados y los afectos.

El libro es una compilación, por un lado, de diferentes textos publicados con anterioridad en múltiples medios digitales y analógicos; y, por otro, de conferencias impartidas en instituciones públicas en el período entre 2011 y 2018. La temática de dichos artículos está organizada en torno a tres ejes que conforman el corpus del libro: la crisis de régimen y el ascenso de las derechas, la revolución feminista y la violencia contra las mujeres y las prácticas relacionales y las políticas de lo común. El texto cierra con un último apartado que incluye dos transcripciones parciales de las conversaciones de la autora con Pablo Iglesias en el programa Otra Vuelta de Tuerka y con Ana Ramos para Radio Web MACBA. En este aspecto, tanto su organización por temáticas como su fácil registro permiten al lector dilucidar de forma diáfana la argumentación de Palop sobre los mecanismos para articular nuevas comunidades políticas que integren las demandas del movimiento feminista.

De este modo, en el primer capítulo del libro, Palop pone en relación el auge de la extrema derecha con el contexto de desigualdad y fractura social generado por las intrínsecas contradicciones del neoliberalismo. A su modo de ver, el incremento de la ultraderecha se articula como respuesta a la crisis que atraviesa el modelo político contemporáneo, la cual tiene su origen en dos causas fundamentales. Por un lado, la consideración de la política como business, que ha consolidado la democracia como un mercado; y, por otro lado, el funcionamiento de la estructura interna de los partidos, cuya obsesión por la estabilidad y sus luchas internas por el poder han agravado el déficit de legitimidad democrática que caracteriza el sistema político contemporáneo. 
Asimismo, Palop sostiene que el ascenso ultraderechista está íntimamente ligado a la imposibilidad de la izquierda de articular un discurso unificado. A la pregunta: ¿Por qué las derechas pueden cautivar a buena parte de la clase obrera? (p. 12) la autora responsabiliza a la incapacidad de las izquierdas para «conjugar la eficiencia económica con los valores igualitarios» junto con la conquista fracasada de «nuevos nichos electorales» (p. 16). Centrados en priorizar las políticas de reconocimiento de identidades frente a los conflictos de redistribución - los oprimidos cool ante las clases populares tradicionales -, los partidos socialdemócratas de izquierdas han optado por anteponer la gobernabilidad a la democracia real, lo que les ha llevado a dar apoyo a políticas de austeridad tatcheristas como el TINA - «there is no alternative» -. Ante su descrédito ideológico agravado por el estallido de la última crisis financiera, Palop razona que la renuncia de las izquierdas a la soberanía popular en favor del mantenimiento del status quo ha conllevado un trasvase de votos hacia las fuerzas ultraderechistas, quienes han conseguido definir el malestar popular señalando chivos expiatorios -como los inmigrantes o los refugiados - como culpables de la crisis. Compatibilizando el discurso económico neoliberal con el discurso del miedo, Palop argumenta que la xenofobia y el autoritarismo de la extrema derecha han marcado la agenda de la política general, llegando a permear las estrategias de las formaciones predominantes. A modo de ejemplo, la autora alude a las políticas laborales de Angela Merkel en relación a los inmigrantes, la expulsión de los extranjeros llevada a cabo por Theresa May en Inglaterra o la restricción del derecho de asilo en la Austria de Sebastian Kurz. Siendo esta política únicamente lucrativa para las élites, la extrema derecha está liderando, en palabras de Slavoj Zizek, «una revolución sin revolución» (p. 33); un cambio social sin cambio real que opera ocultando la violencia inherente al sistema capitalista contemporáneo.

Frente al auge de las derechas, Palop pone en valor, en el segundo capítulo, las revoluciones que protagonizaron la marea global feminista iniciada en 2011 . Tras efectuar una breve cronología mundial de las manifestaciones más determinantes, la autora, a propósito de las movilizaciones del 8M español, describe la situación de desigualdad estructural a la que están expuestas las mujeres: «sufren más paro, más jornadas parciales, una abultada brecha salarial, [...] falta de paridad en los órganos de poder y una escasa representación en los puestos de responsabilidad y dirección» (p. 40). Ante este escenario, Palop defiende que la reivindicación del 8M se articuló a favor del «feminismo del 99\%» frente al «feminismo empresarial o feminismo del 1\%», que sólo conseguía la emancipación de una minoría privilegiada. A continuación, Palop recuerda la importancia que el 8M le dio al cuerpo, considerándolo un campo de batalla que se resistía a la mercantilización patriarcal y que, a su vez, sacaba a la luz dos cuestiones fundamentales. Por un lado, la necesidad de construir una ética del cuidado basada en la autonomía entendida como sinergia relacional, y, así, poder revertir la crisis de cuidados que vertebra la relación de desigualdad interseccional e intragénero entre el norte y el 
sur global. Y, por otro lado, el reclamo del cuerpo como lugar donde la complejidad y pluralidad de las identidades se pone de manifiesto, quedando inoperativo cualquier macrorrelato que apelase a un único sujeto identitario - como el sindicalismo ha podido perpetuar con la etiqueta de mujer trabajadora - para alentar su politización. Finalmente, cerrando el capítulo, Palop destaca cómo el 8M visibilizó la aterradora actualidad de la violencia machista. Refiriéndose al debate sobre la prostitución y la gestación subrogada como dos ejemplos donde la violencia sufrida por las mujeres puede quedar invisibilizada, Palop desacredita los mitos que responsabilizan y aíslan a las mujeres víctimas de violencia y expone los factores estructurales - como el sistema productivo o el funcionamiento del sistema judicial - que contribuyen diariamente a su naturalización.

Por lo que hace al tercer capítulo, con el objetivo de concretar las reivindicaciones del movimiento feminista en propuestas de política pública, Palop defiende las llamadas políticas de lo común, que se sustentan en tres pilares: la interdependencia, la ecodependencia y la radical vulnerabilidad. Articuladas como resistencia al proyecto disuasorio neoliberal y orientadas a desbancar la idea del sujeto moderno inmune y autosuficiente, Palop aboga por políticas transformacionales que consideren los cuidados como una «virtud cívica y un deber público de civilidad» (p. 90) y diluyan, así, la separación entre la esfera pública y privada. Asimismo, en su propuesta de una filosofía de lo común, Palop defiende la centralidad del concepto de responsabilidad entendida no como la consecuencia necesaria de pertenecer a una comunidad sino como la condición vivencial que reafirma los vínculos de dependencia con los otros. Para Palop, la responsabilidad debe articularse acorde con las generaciones pasadas y futuras, construyendo así un vínculo intergeneracional que entienda la justicia como reciprocidad. En este sentido, hacer política con el pasado significa, para Palop, tomar en consideración las políticas de la memoria que luchan contra el olvido historicista, mientras que la mirada al futuro debe hacer suyas las demandas del ecofeminismo en relación a la soberanía de los comunes. En suma, Palop defiende una política de lo común estructurada en torno a cinco ejes: la radicalidad democrática y la nueva institucionalidad, la distribución de la riqueza y la justicia social, la descentralización del poder y el autogobierno, la identidad relacional y el reconocimiento, y la feminización de la política.

Finalmente, las transcripciones de la autora con Pablo Iglesias y Ana Ramos recogen los pilares fundamentales de la política propuesta por Palop. Reivindicando la importancia de la utilización del derecho como instrumento de transformación social, Palop cree, con Nancy Fraser, que las crisis que atraviesan España -de Régimen, de Modelo de Organización Territorial y de Estado Social - deben combatirse mediante la resolución de los conflictos de participación, redistribución y reconocimiento de forma simultánea. Además, necesariamente, dichas propuestas deben ser articuladas de forma local y en clave feminista, construyendo, así, políticas municipalistas en red encabezadas por liderazgos en femenino. 
En síntesis, Revolución Feminista y políticas de lo común frente a la extrema derecha es un texto claro y accesible para entender la nueva oleada de autoritarismo que atraviesa Europa y cómo el feminismo puede articularse como su dique de contención. En un mundo beligerante y belicista, María Eugenia Rodríguez Palop nos recuerda, desde la política de los afectos, la radical vulnerabilidad que atraviesa la experiencia humana, $\mathrm{y}$, consiguientemente, la necesaria la centralidad de los cuidados para la transformación de nuestras comunidades políticas.

Cuidar de quem cuida: histórias e testemunhos de um trabalho invisível. Um manifesto para o futuro, de José Soeiro, Mafalda Araújo e Sofia Figueiredo. Objectiva, Penguim Random House: Lisboa, 2020, 239 pp.

Manuel Abrantes SOCIUS/CSG - Investigação em Ciências Sociais e Gestão, ISEG, Universidade de Lisboa

Num artigo de 2005, Michael Burawoy descreve as características distintivas da sociologia pública. Refere, a par de outros aspetos, o diálogo entre investigador/a e população estudada, o contributo para debates além da academia e o carácter orgânico da produção de saber: o desafio passa por «tornar o invisível visível, tornar o privado público, validar estas ligações orgânicas como parte da nossa vida sociológica» (Burawoy 2005, 7-8, tradução nossa).

Nesta perspetiva se inscreve o presente livro. Anuncia-se logo nas páginas iniciais como reacção a um problema social: a insuficiência do atual modelo de cuidados, marcado por acentuadas desigualdades de género e de classe, num contexto em que a mercantilização não pode garantir o acesso universal às infraestruturas necessárias. Se a organização social dos cuidados já vinha suscitando um debate crescente nos últimos anos, a pandemia da Covid-19 contribuiu para expor a urgência da temática (Dias, Brasão e Abrantes 2020). Escrito por um sociólogo, uma socióloga e uma dirigente associativa, o livro apresenta uma linguagem e uma organização de conteúdos que o tornam estimulante para públicos com diferentes graus de especialização, sem sacrificar qualquer premissa do trabalho académico: a solidez teórica, o dispositivo metodológico, a fundamentação empírica das conclusões, o sentido crítico permanente.

A primeira parte do livro divide-se em três capítulos. No capítulo inicial realiza-se um mapeamento do universo dos cuidados, campo vasto e complexo que abrange trabalho pago e trabalho não pago, esfera privada e esfera pública, e grupos profissionais variados - a heterogénea classe dos cuidados abarca médicos/ /as, enfermeiros/as, técnicos/as, auxiliares, assistentes, educadoras/es, administra- 
tivos/as e empregados/as domésticos/as, entre outras categorias. O segundo capítulo debruça-se especificamente sobre os cuidados informais em Portugal, descrevendo quer as suas componentes institucionais e históricas, quer as vivências de cuidadores/as a partir de testemunhos recolhidos para o efeito. O terceiro capítulo revê a literatura feminista sobre a desvalorização do cuidado, dos colectivos militantes na década de 1970 aos contributos mais recentes do feminismo descolonial.

A segunda parte do livro é focada nas políticas públicas de cuidado em Portugal, examinando, num primeiro capítulo, as suas tensões e transformações; e discutindo, num segundo, alternativas possíveis e experiências de medidas adotadas noutros países da Europa. A terceira parte do livro oferece um sumário das conclusões e um conjunto de recomendações agregadas no «Manifesto por uma nova política do cuidado». Trata-se de delinear soluções com base na análise dos capítulos precedentes, proporcionando a cada leitor/a as ferramentas para compreender a argumentação, concordar ou discordar das propostas e, em qualquer dos casos, prosseguir e aprofundar o diálogo.

Merece destaque o contributo do livro para clarificar a dimensão e o valor económico dos cuidados. Segundo um estudo global da Organização Internacional do Trabalho (ILO, 2018), o trabalho de cuidado corresponde a 12\% do emprego mundial, ou seja, 381 milhões de trabalhadores/as. O mesmo estudo calcula que o trabalho reprodutivo não remunerado, no qual se incluem os cuidados informais prestados a parentes ou pessoas amigas, equivale a 9\% do PIB mundial. A Eurocarers - European Association Working for Carers, em 2017, estimava um total de 827 mil cuidadores/as informais em Portugal, cerca de $8 \%$ da população. Outras fontes são examinadas no livro, concluindo-se que a quantificação dos cuidados é estorvada, em Portugal como noutros países, por um leque de fatores: dificuldade em delimitar objetivamente os cuidados, inexistência de categorias estatísticas adequadas para este fim, subcontratação abundante no setor público e no setor privado, peso substancial da economia informal (contratação indeclarada). As lacunas de medição não devem ser entendidas como arbitrárias, nem como mero fruto de inércia ou ineficácia administrativa. «Ainda hoje», como lemos na página 118, «só é contabilizado aquilo que é politicamente reconhecido».

Igualmente digna de nota é a atenção prestada ao quotidiano de cuidadores/ as, incluindo as suas tarefas, estratégias, sacrifícios, modos de organização dos espaços e tempos domésticos, e consequências para a saúde mental. Uma observação empírica rigorosa é essencial para os avanços da teorização e do debate. $\mathrm{O}$ presente livro ilumina a relação dinâmica e multiforme entre as adversidades no mercado de trabalho - os horários longos, os salários baixos, a precariedade e as estratégias familiares de prestação de cuidados a crianças, pessoas idosas ou pessoas com deficiência. Mostra também como essas estratégias, por sua vez, estão interligadas com decisões potencialmente discriminatórias das entidades patronais quando se deparam com trabalhadores/as, sobretudo mulheres, 
que têm de combinar a atividade profissional com a prestação de cuidados na esfera familiar.

As especificidades de Portugal são claramente enunciadas ao longo do livro, permitindo discernir padrões internacionais e singularidades do caso nacional. A insuficiência do sistema público de cuidados é explicada à luz de um Estado social tardio e de um modelo de reprodução social «familialista», mas também do envelhecimento demográfico e da contenção dos orçamentos públicos. O Estado assume funções de financiador ou regulador dos cuidados sociais, não de fornecedor, mantendo-se um panorama de assistencialismo no qual nem a forte presença das instituições de cariz caritativo-religioso tem colmatado a escassez de oferta.

As medidas de política pública para uma melhor articulação da atividade profissional com a prestação de cuidados, entre as quais a redução do horário de trabalho, as licenças para assistência à família e as formas flexíveis de organização do trabalho, estão concebidas em primeira instância para a prestação de cuidados a crianças e adequam-se menos à realidade dos cuidados a pessoas idosas. Os/as autores/as mostram como o mesmo viés se manifestou, após a declaração de pandemia em 2020, no apoio diferenciado concedido às famílias perante o encerramento das escolas e perante o encerramento dos centros de dia.

A desvalorização social e económica do cuidado está estreitamente relacionada com as fragilidades da organização coletiva e do poder negocial dos/as cuidadores/as. Esta ligação torna-se evidente quando os/as autores/as traçam o percurso do movimento social que conduziu à aprovação do Estatuto do Cuidador Informal na Assembleia da República em julho de 2019, enfatizando a sua marca de género e as reivindicações formuladas desde 2016. Se entre estas encontramos necessidades concretas em matéria de transportes, consultas médicas, apoio domiciliário, instituições de acolhimento especializadas, direitos e deveres fiscais, entre outras, encontramos também uma exigência mais ampla no plano simbólico: a dignificação dos cuidados informais, prestados frequentemente com grande sofrimento e sacrifício pessoal. A análise mostra que o debate não envolveu apenas o movimento de cuidadores/as e o Estado: nele intervieram instituições de solidariedade social, sindicatos, confederações patronais. Contrariando a noção de que se trataria de um assunto com o qual poucos se importam, verifica-se afinal que muitos têm algo em jogo. Com efeito, a invisibilidade do trabalho realizado na esfera doméstica deve menos a um desinteresse generalizado pelo assunto que ao oposto: a consciência nítida de que o modo como organizamos coletivamente este trabalho tem repercussões para todas as partes, alterando a distribuição de custos e benefícios que há muito tempo penaliza duramente as mulheres e as famílias com baixos rendimentos (Abrantes 2013).

Por último, saliente-se o contributo do livro para conhecermos algumas políticas que outros países têm implementado relativamente a cuidadores/as informais, em particular os orçamentos pessoais na Holanda, o subsídio de cuidador/a no Reino Unido e o assalariamento e proteção social na Finlândia e na 
Suécia. Os potenciais e riscos destas experiências são analisados sem perder de vista as diferenças institucionais e socioeconómicas entre os países. É ainda discutido o desafio comum de reconhecer o trabalho de cuidadores/as informais sem com isso incentivar desigualdades de género nem reforçar inadvertidamente o entendimento do cuidado como uma responsabilidade familiar ao invés de um direito social.

Fica por definir o Estado ideal no qual se baseia o entendimento dos/as cuidadores/as informais como existindo numa «clandestinidade legal» ou como operando «em substituição do Estado» (pp. 60-61). Mais relevante, na minha perspetiva, será a construção de um consenso quanto à repartição de responsabilidades e de encargos. Terão medidas como a Rede Nacional de Cuidados Integrados ou o Serviço de Apoio Domiciliário refletido já um pouco desse acordo social? Pensemos no consenso existente quanto aos cuidados a crianças, também este dinâmico e sujeito a ameaças. No artigo que referimos inicialmente, Burawoy $(2005,16)$ indica justamente o consenso como a forma possível de «verdade» na sociologia pública.

\section{Referências}

Abrantes, Manuel. 2013. «A matter of decency? Persistent tensions in the regulation of domestic service.» Revista de Estudios Sociales 45, 110-122.

Burawoy, Michael. 2005. «For public sociology.» American Sociological Review 70 (1), 4-28.

Dias, Nuno, Inês Brasão e Manuel Abrantes. 2020. «Trabalho sem fronteiras: perspetivas sobre os serviços domésticos e a prestação de cuidados. Editorial do Dossier Especial.» Cidades, Comunidades e Territórios 40, iv-xii.

ILO - International Labour Organisation. 2018. Care Work and Care Jobs for the Future of Decent Work. Geneva: ILO. 



\author{
ex æquo $n .{ }^{\circ} 1$ \\ REPRESENTAÇÕES SOBRE O FEMININO
}

\author{
ex æquo n. ${ }^{\circ} 2 / 3$ \\ POLÍTICAS DE IGUALDADE \\ ex æquo n. ${ }^{\circ} 4$ \\ MULHERES E DESPORTO \\ ex æquo n. ${ }^{\circ} 5$
}

A CONSTRUÇÃO DOS ESTUDOS SOBRE AS MULHERES EM PORTUGAL

ex æquo n. ${ }^{\circ} 6$

A CONSTRUÇÃO DOS ESTUDOS SOBRE AS MULHERES EM PORTUGAL II

ex æquo n. ${ }^{\circ} 7$

OUTROS SENTIDOS PARA NOVAS CIDADANIAS

ex æquo n. ${ }^{\circ} 8$

RECONCEPTUALIZAÇÕES FILOSÓFICAS E DE TEORIA POLÍTICA. PERSPECTIVAS FEMINISTAS

ex æquo n. ${ }^{\circ} 9$

FILOSOFIA E LITERATURA EM TEXTOS DE MULHERES 


$$
\text { ex æquo n. }{ }^{o} 10
$$

DIREITO DA IGUALDADE DE GÉNERO

$$
\text { ex æquo n. }{ }^{\circ} 11
$$

POLIFONIAS NA INVESTIGAÇÃO EM TORNO DOS ESTUDOS SOBRE AS MULHERES

ex æquo n. ${ }^{\circ} 12$

UM LEGADO DE CIDADANIA:

HOMENAGEM A MARIA DE LOURDES PINTASILGO

ex æquo n. ${ }^{o} 13$

MULHERES, PARTICIPAÇÃO E DEMOCRACIA

ex æquo n. ${ }^{\circ} 14$

REPRESENTAÇÕES MEDIÁTICAS DE MULHERES

ex æquo n. ${ }^{\circ} 15$

GÉNERO, PROBLEMÁTICAS E CONTEXTOS EDUCACIONAIS

$$
\text { ex æquo n. }{ }^{o} 16
$$

GÉNERO, RESPONSABILIDADE SOCIAL E CIDADANIA. VOLUNTARIADO E EDUCAÇÃO NÃO-FORMAL

$$
\text { ex æquo n. }{ }^{o} 17
$$

VOZES DE MULHERES DO SUL 


\author{
ex æquo n. ${ }^{\circ} 18$ \\ GÉNERO E MERCADO DE TRABALHO
}

ex æquo n. ${ }^{\circ} 19$

OS ESTUDOS SOBRE AS MULHERES, DE GÉNERO E FEMINISTAS EM REVISTA

ex æquo $n .^{\circ} 20$

FAZER O GÉNERO: PERFORMATIVIDADES E ABORDAGENS QUEER

ex æquo $n .^{\circ} 21$

MARIA DE LOURDES PINTASILGO, CINCO ANOS DEPOIS.

ECOS DE PALAVRAS DADAS

ex æquo n. ${ }^{\circ} 22$

HABITAR

ex æquo $n .^{\circ} 23$

GÉNERO E IDENTIDADES

ex æquo $n .^{\circ} 24$

GÉNERO E MIGRAÇÕES

ex æquo $n .^{\circ} 25$

POLÍTICAS DE IGUALDADE SEXUAL EM PORTUGAL:

EVOLUÇÕES, INSTRUMENTOS E PROTAGONISTAS 


$$
\text { ex æquo n. }{ }^{o} 26
$$

GÉNERO E ENVELHECIMENTO: INDICADORES, PROBLEMÁTICAS

E DESAFIOS PARA A INTERVENÇÃO

ex æquo n..$^{\text {o } 27}$

POLÍTICAS FEMINISTAS NAS ARTES VISUAIS E PERFORMATIVAS

ex æquo n. ${ }^{\circ} 28$

PERSPETIVAS FEMINISTAS EM COMPORTAMENTO DESVIANTE

ex æquo n. ${ }^{\circ} 29$

PERSPETIVAS FEMINISTAS SOBRE METODOLOGIA E EPISTEMOLOGIA: DEBATES, DESAFIOS E DILEMAS

ex æquo n. ${ }^{\circ} 30$

HISTÓRIA, HISTÓRIA DAS MULHERES, HISTÓRIA DO GÉNERO. PRODUÇÃO E TRANSMISSÃO DO CONHECIMENTO HISTÓRICO

$$
\text { ex æquo n. } .^{o} 31
$$

VIOLÊNCIAS DE GÉNERO E DIREITO(S): DIÁLOGOS FEMINISTAS

$$
\text { ex æquo n. }{ }^{\text {o }} 32
$$

\section{Editorial: Virgínia Ferreira}

Dossier: Austeridade e Regimes de Bem-estar e de Sexo/Género

Coordenação: Virgínia Ferreira e Rosa Monteiro

Introdução - Austeridade e Regimes de Bem-estar e de Sexo/Género, Virgínia Ferreira e Rosa Monteiro 
Women and austerity in Italy, Maria Luigia Segnana and Paola Villa

Las políticas de género en España: Retrocesos y resistencias en tiempos de austeridad, Alba Alonso

Austeridade, emprego e regime de bem-estar em Portugal: Em processo de refamilização?, Virgínia Ferreira e Rosa Monteiro

Unemployment and gender equality within the family in Portugal, Raquel Ribeiro, Lina Coelho and Alexandra Ferreira-Valente

Portugal's Masculinities Crisis: Gender equality in the era of flagging economies, Tatiana Moura, Esther Spindler and Alice Taylor

Experiências de Conciliação: Analisando as relações de género durante a atual crise económica, Cláudia Múrias

Las mujeres jóvenes en España. (Nuevas) precariedades y (viejas) desigualdades, Mercedes Alcañiz, Vicent Querol y Ana Marti

\section{Estudos e Ensaios}

Preservando a relação com os/as descendentes menores: padrões de comunicação na maternidade e paternidade em reclusão, Catarina Vieira, Luísa Saavedra e Alexandra M. Araújo

The pathologisation of sexual diversity - a critical scrutiny of the DSM, Rita Alcaire

The Inclusion of Lesbian and Gay Populations in Health Research: A systematic literature review, Mónica José Abreu Sousa and Carla Moleiro

Home-Based Sex Education. The Case of Family Intergenerational Relations in Poland, Joanna Ostrouch-Kaminśka and Iwona Chmura-Rutkowska

\section{Recensões}

Simas, Rosa M. Neves (coord.), (2014), A Vez e a Voz da Mulher. Relações e Migrações, Lisboa, Colibri, 340 pp., Maria Beatriz Rocha Trindade

Ferreira, Virgínia; Monteiro, Rosa (2013), Trabalho, igualdade e diálogo social: Estratégias e desafios de um percurso, Lisboa, Comissão para a Igualdade no Trabalho e no Emprego, Hermes Costa

Ferreira, Eduarda; Ventura, Isabel; Rego, Luísa; Tavares, Manuela; Almeida, Maria Antónia Pires de (orgs.) (2014), Percursos Feministas: Desafiar os tempos, Lisboa, UMAR/Universidade Feminista, e-book, Orlando César

Karamessini, Maria; Rubery, Jill (org.) (2014), Women and Austerity: The Economic Crisis and the Future for Gender Equality, New York, Routledge, Carina Jordão

ex æquo n. ${ }^{\text {o }} 33$

Editorial: Virginia Ferreira

Dossier: Género, Profissões e Carreiras: Oportunidades, Constrangimentos e Desafios

Coordenação: Gina Gaio Santos e Teresa Carvalho 
Género, profissões e carreiras: oportunidades, constrangimentos e desafios: uma nota introdutória, Gina Gaio Santos e Teresa Carvalho

The university environment: opportunities, constraints and challenges for senior women, Jenny Neale and Kate White

«As mulheres tentam compensar. O verbo 'compensar' é terrível, não é?» Género e jornalismo em tempos de mudança, Maria João Silveirinha e Rita Basilio de Simões

A contabilidade, o acesso e o exercício da profissão de contabilista certificado/a na perspetiva das mulheres, Vera Fernandes, Delfina Gomes e João Leite Ribeiro

Questões de género em arquitetura. História(s), espaço(s) e experiências profissionais e arquitetónicas, Lia Antunes

Gender and atypical academic careers, Kate White and Maria de Lourdes Machado-Taylor

Entre mulheres: o ensino doméstico e a profissão, Álvaro Ribeiro

Processos de discriminação de profissionais imigrantes e qualificadas em contextos laborais tipicamente masculinos, Ana Filipa Carvalho e Emília Fernandes

\section{Estudos e Ensaios}

O género no jornalismo em tempos de recessão: como se dá a representação mediática das mulheres num contexto de crise em Portugal, Juliana Souza

Mulheres no ensino superior brasileiro: espaço garantido e novos desafios, Arlene Ricoldi e Amélia Artes

\section{Recensões}

Ollagnier, Edmée (2014), Femmes et défis pour la formation des adultes. Un regard critique non-conformiste, Paris, L'Harmattan, 258 pp., Teresa Pinto

Ostrouch-Kaminska, Joanna; Vieira, Cristina C. (Eds.) (2015), Private world(s). Gender and Informal learning of adults, Rotterdam, Sense Publishers, 194 pp., Edmée Ollagnier

Neves, Sofia; Duarte, Vera; Barbosa, Regina Célia; Formiga, Nilton (Eds.), (2015), Violências na Contemporaneidade no Brasil e em Portugal, Maia, Edições ISMAI, 214 pp., Sílvia Gomes e Luís Fernandes

Meihy, José Carlos S. B. (2015), Prostituição à brasileira - cinco histórias, São Paulo, Editorial Contexto, 240 pp., Camila Craveiro

\section{ex æquo n. ${ }^{\circ} 34$}

Editorial: Virginia Ferreira

\section{Dossier: Perspetivas Interdisciplinares sobre o Femicídio \\ Coordenação do Dossier: Sofia Neves}

Femicídio: o fim da linha da violência de género, Sofia Neves

Feminicídio: uma leitura a partir da perspectiva feminista, Tânia Teixeira Laky de Sousa

Femicide of girls in contemporary India, Shalva Weil and Nishi Mitra vom Berg 
O feminicídio de Juárez: alterações económicas, narrativas sociais e discursos coloniais na fronteira dos EUA e México, Patrícia Alves Lobo

Análisis psicosocial de las barreras que dificultan la denuncia: el caso de los femicidios íntimos en España, Victoria A. Ferrer Pérez y Esperanza Bosch Fiol

Narrativas mediáticas sobre o femicídio na intimidade: análise de um jornal popular português, Sofia Neves, Silvia Gomes e Dircelena Martins

Changing representations of intimate partner femicides by a Portuguese newspaper (2006 and 2014): from episodic to thematic frames, Carolina Magalhães-Dias e Soraia Lobo

\section{Estudos e Ensaios}

Reconciling work and family in the context of boundaryless careers: academic careers in social sciences and humanities, Debbie Millard

Gênero, autoginografia e performatividade em Margaret Skinnider, Raimundo Sousa

Boys' and girls' cyberbullying behaviours in Portugal: Exploring sex differences in adolescence using gender lenses, Cristina C. Vieira, Armanda Matos, João Amado, Isabel Freire and Ana Margarida Veiga Simão

\section{Recensões}

Estudos de Género numa perspetiva interdisciplinar, organizado por Anália Torres, Helena Sant' Ana e Diana Maciel. Lisboa: Mundos Sociais, 2015, 134 pp., Joana Zózimo

Ecología y género en diálogo interdisciplinar, editado por Alicia H. Puleo. Madrid: Plaza y Valdés Editores, 2015, 415 pp., Rosana Albuquerque

The Men's Shed Movement. The Company of Men, edited by Barry Golding. Champaign, Illinois: Common Ground, 2015, 433 pp., Cristina C. Vieira

Gender in Focus: (new) trends in media, edited by Carla Cerqueira, Rosa Cabecinhas e Sara Isabel Magalhães. Universidade do Minho, Braga: CECS, 2016, 240 pp., Roberto Martinez Pecino Marginalidade e alternativa. Vinte e seis filósofas para o século XXI, coordenado por Maria Luísa Ferreira e Fernanda Henriques. Lisboa: Edições Colibri, 2016, 321 pp., Isabel Roldán Goméz

\section{ex æquo n. ${ }^{\circ} 35$}

Editorial: Virginia Ferreira

Dossier: Interseccionalidade, Comunicação e Cultura: (Entre)Cruzamentos de Matrizes de Opressão e Privilégio

Coordenação do Dossier: Carla Cerqueira e Sara I. Magalhães

Ensaio sobre Cegueiras: cruzamentos interseccionais e (in)visibilidades nos media, Carla Cerqueira e Sara I. Magalhães

Feminist Intersectionality Research in Communications: Origins, Contributions and Tensions, Carolyn M. Byerly 
Mulher jovem e a cibercultura: liberdade, subordinação e reminiscências patriarcais no meio virtual, Mariana Risério Chaves de Menezes e Vanessa Ribeiro Simon Cavalcanti

Género, Sexualidade e Ativismo Online: Um olhar interseccional para o papel da participação cívica na internet por jovens portugueses, Daniel Cardoso e Cristina Ponte

Poder, resistência e interseccionalidade: as disputas discursivas por identidade no seriado brasileiro 'Sexo e as Negas', Nelson Rosário de Souza, Viritiana Aparecida de Almeida e Daniela Rocha Drummond

Das margens para o ecrã: mulheres na ficção cinematográfica moçambicana, Ana Cristina Pereira

La construcción mediática del estigma de prostituta en España, Ana Belén Puñal Rama e Ana Tamarit

O cruzamento entre género e nacionalidade e a perspetiva da regulação de conteúdos mediáticos, Alexandra Figueiredo e Carla Martins

\section{Estudos e Ensaios}

O Pecado da Carne: neomaterialismo e a (re)descoberta do corpo, Caynnã de Camargo Santos

El uso del subtexto como propaganda machista en el personaje de Lois Lane en Man of Steel (Zack Snyder, 2013), Alfonso M. Rodríguez de Austria Giménez de Aragón

Uma sabedoria no desespero. Há que gritar aos ouvidos da aparente surdez: Somos todas Carolina!, Elaine Santos

\section{Recensões}

Rethinking Gender in Revolutions and Resistance. Lessons from the Arab World, edited by Maha El Said, Lena Meari, \& Nicola Pratt. London: Zed Books, 2015, 262 pp., Verónica Ferreira Introdução às Teorias Feministas do Direito, de Rita Mota Sousa. Porto: Edições Afrontamento, 2015, 96 pp., Madalena Duarte

Nas Filigranas do Discurso jurídico, a (des)construção de sentidos na Lei Maria da Penha, de William Diego de Almeida. Campo Grande: Editora UFMS, 2015, 163 pp., Icléia Caires Moreira

Rewriting Academia. The development of the Anglicist Women's and Gender Studies of Continental Europe, edited by Renate Haas. Frankfurt am Main: Peter Lang, 2015, 442 pp.

Contemporary issues and perspectives on gender research in adult education, edited by Maja Maksimovic, Joanna Ostrouch-Kaminska, Katarina Popovic, \& Aleksandar Bulajic. Belgrade: Institute for Pedagogy and Andragogy, Faculty of Philosophy, University of Belgrade; ESREA - European Society for Research on the Education of Adults; Adult Education Society, 2016, 284 pp., Shirley Walters

\section{ex æquo n. ${ }^{\circ} 36$}

Editorial: Virgínia Ferreira

Dossier: Género, educação e cidadania: conhecimento, ausências e (in)visibilidades

Coordenação do Dossier: Cristina C. Vieira e Teresa Alvarez 
Género, educação e cidadania: que «agenda» para a investigação científica e para o ensino e a formação?, Teresa Alvarez, Cristina C. Vieira e Joanna Ostrouch-Kamińska

Género e (in)sucesso escolar: perspetivas de professoras/es do ensino básico sobre possíveis consequências da feminização do ensino, Maria Helena Santos

La perspectiva de género en la formación inicial del profesorado de educación infantil. Notas sobre una investigación realizada entre el alumnado del grado de magisterio de educación infantil de la universidad de Cantabria (España), Marta García Lastra

Jovens estudantes universitários/as perante a futura vida profissional e familiar: a marca do género, Sofia Coelho e Sara Falcão Casaca

Violência no namoro na Escola Superior de Educação de Lisboa, Ana Gama, Ana Veríssimo e Catarina Tomás

Armarios de papel: el heterosexismo en los manuales de Español como Lengua Extranjera, Maria Salvia Rodríguez

Para uma visão complexa do bullying homofóbico: Desocultando o quotidiano da homofobia nas escolas, Hugo M. Santos, Sofia Marques da Silva e Isabel Menezes

Gender in contemporary Italian context. A focus on informal education and proposals for a gender sensitive approach through intergenerational and intercultural dimensions, Lisa Brambilla, Giulia Pozzebon and Marialisa Rizzo

Diversidade de género na infância e na educação: contributos para uma escola sensível ao (trans) género, Sandra Saleiro

Brincar ao género: socialização e igualdade na educação pré-escolar, Catarina Sales Oliveira e Andreia Mendes

\section{Estudos e ensaios}

A inexpressiva representação feminina nas academias científicas brasileiras e no prêmio nobel, Marcel de Almeida Freitas e Eduardo Godinho Pereira

Que horas ela volta?: Percepções do discurso fílmico por blogueiras feministas do Brasil, Denise Castilhos de Araújo e Poliana Lopes

\section{Recensões}

Sexualidades, gravidez e juventude: relações sociais e educativas, organizado por Laura Fonseca e Sofia Santos. Porto: Edições Afrontamento, 2015, 312 pp., Preciosa Fernandes

Filosofia e Género. Outras narrativas sobre a tradição ocidental, de Fernanda Henriques. Lisboa: Edições Colibri, 2016, 256 pp., Maria do Céu Pires

Como ser uma Ragazza: Discursos de sexualidade numa revista para raparigas adolescentes, de Sara Isabel Magalhães. Saarbrücken: Novas Edições Acadêmicas, 2016, 353 pp., Nuno Santos Carneiro

La comunicación en clave de igualdad de género, coordenado por Virgínia Martín Jiménez y Dunia Etura. Madrid: Editorial Fragua, 2016, 134 pp., Carla Cerqueira

Géneros e sexualidades: interseções e tangentes, editado por João Manuel de Oliveira e Lígia Amâncio. Lisboa: Centro de Investigação e de Intervenção Social (CIS-IUL), 2017, 222 pp., Mara Pieri 


\section{ex æquo n. ${ }^{\circ} 37$}

Editorial: Virgínia Ferreira

Dossier: A «Ideologia de Género» e a Religião

Coordenação do Dossier: Carmen Bernabé Ubieta - Facultad de Teología, Universidad Deusto, España.

Fernanda Henriques - Universidade de Évora (Professora Emérita), Portugal.

Teresa Toldy - Universidade Fernando Pessoa, Porto/Centro de Estudos Sociais da Universidade de Coimbra, Portugal.

As engrenagens do poder: sobre alguns encaixes entre direito, ciências e transexualidades A «Ideologia de Género» da Igreja Católica, Carmen Bernabé Ubieta, Fernanda Henriques e Teresa Toldy

Las falacias discursivas en torno a la ideología de género, Maricel Mena-López y Fidel Mauricio Ramírez Aristizábal

'Ideologia de gênero' e a política de educação no Brasil: exclusão e manipulação de um discurso heteronormativo, Priscila Freire

La disputa del género en el Estado español desde el análisis del activismo católico, Maribel Blázquez-Rodríguez, Mónica Cornejo-Valle y José Ignacio Pichardo-Galán

Salvando las Ánimas. Discursos de Género y Religión en las Revistas de la Acción Católica Española, Sara Martín Gutiérrez y Gabriela de Lima Grecco

Represión sexual y de género en la confesión: los manuales de confesores de la Edad Moderna (siglos XVI-XVII), Andrea Arcuri

Intimidad humana: ciencias de la vida, neuroteología fundamental y ciberfeminismo, Montserrat Escribano-Cárcel

\section{Estudos e ensaios}

Ordem Patriarcal de Gênero, Mediação e Serviço Social, Taynara Fitz Patriarcha e Sandra Lourenço de Andrade Fortuna

Percepciones de equidad de género en las/os futuras/os profesoras/es, Ilsa Mendoza Mendoza y Susan Sanhueza Henríquez

Violência sexual e consumo de substâncias psicoativas: podem os contextos festivos ser educativos?, Cristiana do Vale Pires, Raquel Pereira, Helena Valente e Helena Moura

\section{Recensões}

Power, Knowledge and Feminist Scholarship: an ethnography of academia, de Maria do Mar Pereira.

Oxon e Nova Iorque: Routledge, 2017, 228 pp., Ana Oliveira

Handbook on Gender and Organizational Change, de Sara Falcão Casaca e Johanne Lortie, Turin, Italy: International Training Centre of the International Labour Organization, 2017, 117 pp., Maria Helena Santos 
Cómo informar sobre la violencia machista, de José María Calleja, Madrid: Signo e Imagen, 2016, 168 pp., Pedro Saraiva

\section{ex æquo n. ${ }^{\circ} 38$}

Editorial: Cristina Vieira e Virgínia Ferreira

Dossier: Trans-ações de género: ressonâncias e saberes trans*

Coordenação do Dossier: João Manuel de Oliveira (Universidade Federal de Santa Catarina, Brasil/ISCTE-IUL)

Trans-ações de género, operando contra o cistema, João Manuel de Oliveira

As engrenagens do poder: sobre alguns encaixes entre direito, ciências e transexualidades no Brasil, Thiago Coacci

Heróis no armário: homens trans* e pessoas não binárias prestadoras de cuidado, Ana Cristina Santos

Memorias posibles para el Movimiento Trans* en Ecuador, Fernando I. Sancho Ordoñez y R. Lucas Platero

La voluntad de existir: historias de violencia en una colectividad de mujeres trans, Mar Fournier Pereira

Tecnologias de gênero e magia: hormonioterapia e as experiências de vida de mulheres trans*, André Filipe dos Santos Leite e Claudiene Santos

Resistências e rejeições nas vivências de pessoas trans no Candomblé da Bahia, Claudenilson Dias e Leandro Colling

¡Faltan palabras! Las personas no binarias en el Estado español, Isabel López Gómez y R. Lucas Platero

Gozar os géneros: para uma escuta queer de não-binarismos de género, Teresa Teixeira e Nuno Santos Carneiro

\section{Estudos e ensaios}

Quando a moda é política: as mulheres negras e a Revista Afro Brasil, Larissa Adams Braga, Magna Lima Magalhães e Claudia Schemes

Dinâmicas interacionais do bullying entre meninas: explorando as tramas do aprendizado de gênero, Jamile Guimarães

\section{Recensões}

Women in International and Universal Exhibitions, 1876-1937, editado por Rebecca Rogers e Myriam Boussahba-Bravard. Nova Iorque e Londres: Routledge, 2018, 286 pp. Júlia Garraio

A New History of Iberian Feminisms, editado por Silvia Bermúdez e Roberta Johnson. Toronto: University of Toronto Press, 2018, 544 pp. Macarena García-Avello 
L'Europe des Femmes. XVIIIe-XXIe siècle, coordenado por Julie Le Gac e Fabrice Virgílio, Paris: Perrin, 2017, 351 pp. Teresa Pinto

Medusa no Palácio da Justiça ou uma história da violação sexual, de Isabel Ventura, Lisboa: Tinta da China, 2018, 480 pp. Maria Clara Sottomayor

\section{ex æquo n. ${ }^{\circ} 39$}

\section{Editorial: Virgínia Ferreira}

Dossier: Mulheres na imprensa periódica colonial: discursos e representações

Entre silêncios e interferências: mulheres na imprensa colonial, Jessica Falconi e Doris Wieser A Esperança: A leitura e a escrita de e para mulheres em Cabo Verde, Ricarda Musser Domingas Lazary Amaral - «uma querelada pela liberdade de imprensa», Silvia Espírito Santo

Silêncios no feminino no Boletim da Agência Geral das Colónias /do Ultramar, Sandra Sousa A construção da identidade da Mulher em revistas do Estado Novo, Aldina Marques, Isabel Margarida Duarte, Alexandra Guedes Pinto e Catarina Pinho

Maria Archer: uma etnógrafa amadora na imprensa colonial, Gemma Nadal

Beatriz da Conceição de Ataíde Lobo e Faria: um rosário de contos para a coluna «Leituras para Senhoras», Cielo G. Festino

Sofia Pomba Guerra: uma feminista na Imprensa Moçambicana dos anos 1930, Pamela Peres Cabreira e Luís Carvalho

Irene Gil e Sofia Pomba Guerra: vozes de mulher es portuguesas em Moçambique nas páginas de Itinerário, Ada Milani

Maria Firmina dos Reis, decolonialidade e escrita abolicionista na imprensa maranhense oitocentista, Cristiane Navarrete Tolomei

\section{Estudos e ensaios}

«You can feel the exhaustion in the air around you»: The Mood of Contemporary Universities and its Impact on Feminist Scholarship, Maria do Mar Pereira

«Cada um no seu canto!»: Olhares de jovens do ensino profissional sobre homossexualidade e masculinidade, Nicolas Martins da Silva e Sofia Marques da Silva

\section{Recensões}

Women's Activisms in Africa. Struggles for Rights and Representation, editado por Balghis Badri e Aili Tripp, Londres: Edição Zed Books, 2017, 250 pp. 209. Sara Vidal

Barbarismos queer y otras esdrújulas, editado por R. Lucas Platero, María Rosón y Esther Ortega. Barcelona: Editorial Bellaterra, 2017, 431 pp. María Teresa Márquez

Género, Direitos Humanos e Desigualdades, coordenado por Anália Torres, Paula Pinto e Cláudia Casimiro, Lisboa, Edições ISCSP, 2018, 337 pp. Helena Pereira de Melo 


\section{ex æquo n. ${ }^{\circ} 40$}

Editorial: Cristina C. Vieira

Dossier: Género e status em politica internacional: Dinâmicas de cooperações, conflitos e ativismos

As múltiplas inter-relações entre questões de género e a aquisição de status na arena internacional Vânia Carvalho-Pinto e Andrea Fleschenberg

Os Elos Perdidos: A atuação feminina na diplomacia luso-brasileira, 1780-1822 Rogério Frias

Gender quotas in Indonesia: Re-examining the role of international NGO(s) Ella Syafputri Prihatini e Wahidah Zein Br Siregar

Driving in the middle of the road: Paradoxes of women's role under the New Saudi Arabian Nationalism

Luiza Cerioli

\section{Estudos e ensaios}

A distant finish line for women: gender and the sports press in Portugal (1996-2016) Pedro Saraiva, Virgínia Ferreira, Maria João Silveirinha

Desidentificações de género: performances subversivas Rita Grave, João Manuel de Oliveira, Conceição Nogueira

The lookism of a senior citizen's ageing body - utopia or reality? The perspective of Polish elderly women and elderly men

Emilia Kramkowska

Maré de Mulheres: reflexões sobre a justiça para mulheres em situação de violência numa favela carioca Marisa Antunes Santiago, Hebe Signorini Gonçalves, Cristiane Brandão Augusto

Necropolítica, políticas públicas interseccionales y ciudadanía trans* Claudia Lazcano Vázquez, Maria Juracy Filgueiras Toneli, João Manuel de Oliveira

\section{Recensões}

Violências de Género, coordenado por Sofia Neves e Dália Costa. Lisboa: CIEG/ISCSP-UL. Coleção Estudos de Género, 2017, 337 pp. Elza Pais

Ecos de Freire e o Pensamento Feminista: Diálogos e Esclarecimentos, coordenado por Eunice Macedo. Porto: IPFP, CRPF e CIIE-FPCEUP, 2017, 239 pp. Alexandra Carvalho

Arquitectas: Modos de (R) Existir. Reflexões a partir de um ciclo de conversas, editado por Patrícia Santos Pedrosa, Joana Pestana Lages e Lia Antunes. Lisboa: Mulheres na Arquitectura, 2018, 100 pp

Isabella Noronha Rusconi 
Women's ILO: Transnational networks, global labour standards and gender equity, 1919 to Present, edited by Eileen Boris, Dorothea Hoehtker e Susan Zimmerman. ILO e BRILL, 2018, 412 pp.

Albertina Jordão

Nuevos horizontes en la literatura latina de Estados Unidos: Transnacionalismos, resistencias queer y sus manifestaciones en la web, editado por Macarena García-Avello. Palma: Edicions Universitat de les Illes Balears, 2018, 196 pp.

Andrea Fernández-García

Gender - Diversity - Intersectionality (New) Perspectives in Adult Education, edited by Martina Endepohls-Ulpe and Joanna Ostrouch-Kamińska. Munster: Waxmann, 2019, 214 pp.

Lidia Bielinis

ex æquo n. ${ }^{\circ} 41$

Editorial: Virginia Ferreira

Dossier: Epistemologias, metodologias e produção de conhecimento crítico de matriz qualitativa em Estudos sobre as Mulheres, de Género e Feministas

Nota Prévia: A abordagem qualitativa para compreensão das questões de género Lucimara Fabiana Fornari e António Pedro Costa

Do pessoal ao político: as metodologias de investigação qualitativa como aliadas da ação Sofia Bergano e Cristina C. Vieira

A construção do pânico moral a partir das questões de gênero e sexualidades nos discursos ultraconservadores no Brasil

Cleide Ester de Oliveira, Nadir de Fátima B. Bittencourt, Veralúcia G. de Souza, Paulo Sesar Pimentel, Kátia Terezinha P. Ormond e Isabel Cristina Silva

Violación de adolescentes en situación de calle en Medellín, Colombia Anghie Phamela López Mejía, Constanza Forero Pulido e Álvaro Giraldo Pineda

Mulheres idosas vítimas de violência: o protagonismo nas denúncias

Daniela Garcia Damaceno, Miriam Fernanda Sanches Alarcon, Viviane Boacnin Yoneda Sponchiado, Mara Quaglio Chirelli, Maria José Sanches Marin e Joyce Fernanda Soares Albino Ghezzi

Struggling for the dignity of women with Relapsing-Remitting Multiple Sclerosis: An interpretative phenomenological single case study analysis

Michaela Miertová, Juraj Čáp e Katarína Žiaková

Maternidade Tardia: da consciencialização do desejo à decisão de ser mãe

Maria Anabela Ferreira dos Santos, Maria dos Anjos Pereira Lopes e Maria Antónia Rebelo Botelho

Perspectivas y experiencias sobre el consumo de bebidas alcohólicas durante el embarazo: estudio cualitativo con embarazadas de España, Francia y Portugal

Renata Franco, Belén Charro e Maria Raul Xavier 


\section{Estudos e ensaios}

La misoginia popular como contramovimiento: estudio de la resemiotización y los discursos manipulativos como desafíos contra el feminismo

Sonia Núñez Puente e Diana Fernández Romero

La invisibilidad normativa de los riesgos psicosociales que afectan a las mujeres trabajadoras. El caso español en perspectiva europea

Raúl Payá Castiblanque

Reclusão feminina: As implicações da visita íntima na adaptação à prisão Rita Pinto e Alexandra Oliveira

Mães cuidadoras, pais imperfeitos: Diferenças de género numa revista portuguesa para mães e pais

Filipa César, Alexandra Oliveira e Anne Marie Fontaine

(Des)Construção da Parentalidade Trans*: Homens que Engravidam

Ana R. Pinho, Liliana Rodrigues e Conceição Nogueira

\section{Recensões}

Feeling Academic in the Neoliberal University. Feminist Flights, Fights and Failures, edited by Yvette Taylor and Kinneret Lahad. London: Palgrave/ Macmillan, 2018, 368 pp. Adriana Bebiano

Re-writing Women as Victims: From Theory to Practice, edited by María José Gámez Fuentes, Sonia Núñez Puente, \& Emma Gómez Nicolau. London: Routledge, 2019, 230 pp. Elizângela Costa de Carvalho Noronha

Feminicídio: uma análise sociojurídica da violência contra a mulher no Brasil, de Adriana Ramos de Mello. Lisboa: GZ Europa, 2020, 3. a edição, 254 pp.

Tiago Rolino

\section{Próximos números \\ ex æquo $n .{ }^{\circ} 44$}

\section{Dossier: Desigualdades sociais e medidas de ação afirmativa}

Coordenação: Carla Cerqueira (Universidade Lusófona - CICANT)

Maria Helena Santos (Instituto Universitário de Lisboa (ISCTE-IUL),

CIS-IUL)

Renísia C. Garcia Filice (Universidade de Brasília/UnB/Brasil)

A igualdade, diversidade e inclusão social tornaram-se objetivos legítimos das sociedades ocidentais, formalizados por diversas convenções e legislações. As desigualdades persistem, no entanto, e as ideologias dominantes têm-se mantido relativamente bem instaladas, contribuindo para a manutenção do sexismo, racismo, classismo e outras formas de dominação. 
Em diferentes contextos geográficos, os grupos intitulados por «minorias» têm-se organizado e constituído ações políticas importantes com vista a serem contemplados na formulação de políticas públicas. A segregação de género na esfera do trabalho é um exemplo disso, persistindo desigualdades no mundo educativo, político, associativo e empresarial que colocam as mulheres em desvantagem, em comparação com os homens, particularmente no que diz respeito aos lugares de poder e tomada de decisão (Santos e Amâncio 2014), complexificando ainda mais quando ao género e à classe, se soma a raça e a etnia, por exemplo (Garcia-Filice 2011).

Partindo de um olhar sobre a segregação de género existente, de facto, após a implementação da democracia e da igualdade formal, rapidamente se começou a perceber que persistiam barreiras informais e invisíveis ligadas ao género que continuavam a dificultar o acesso das mulheres a certos cargos e a progressão nas carreiras (Santos 2011; Santos e Amâncio 2012). Esta realidade é bem patente em diversas esferas e complexifica-se à medida que outros marcadores sociais como a raça, a etnia, a classe, a idade, a orientação sexual e a diversidade funcional são vistos de forma interseccional (Crenshaw 1989; Cerqueira e Magalhães 2017; Collins e Bilge 2018; Akotirene 2019).

O reconhecimento destas múltiplas assimetrias, fruto de reivindicações dos movimentos sociais, feministas e antirracistas (Krook e O’Brien 2010) e das instituições internacionais, como a Organização das Nações Unidas, a União Europeia e o Conselho Europeu (Procacci e Rossilli 1997), nas últimas décadas, a perceção das desigualdades nos resultados, que incide de diferentes formas sobre mulheres, mulheres negras e outras minorias, tem levado países de diversas partes do mundo a implementar várias medidas de ação afirmativa. Ou seja, mais do que seguir a tradicional e lenta "via incremental", percebe-se que medidas como as quotas, por exemplo, se tornaram uma estratégia da "via rápida" (Dahlerup e Freidenvall, 2005) com o objetivo de aumentar a representação das mulheres, nomeadamente, na política. Outros grupos sociais foram também objeto de legislação de quotas, incluindo os baseados na língua, religião, etnia, nacionalidade, raça, casta, idade, expatriação, profissão, domicílio e diversidade funcional (Krook e O’Brien 2010).

No geral, as ações afirmativas resultam de intensas disputas entre movimentos sociais, estados, empresas, uma variada rede de atores num complexo jogo de poder de natureza social, económica e cultural. Embora as medidas de ação afirmativa sejam um mecanismo crucial para redinamizar o progresso no sentido da igualdade, a sua implementação é diversa, nem sempre é uma condição necessária, como se verifica pelos casos da Finlândia e da Dinamarca, mas também não é uma condição suficiente, como ilustram os casos da França e do Brasil (IPU 2020). Além disso, há outras estratégias paralelas e alternativas, para além das quotas, que podem ser desenvolvidas, por exemplo, pela sociedade civil, pelos partidos políticos, pelos parlamentos e/ ou pelos órgãos do Estado (Krook e Norris 2014).

Apesar da rápida difusão das medidas de ação afirmativa em várias regiões do mundo e tipos de sistemas políticos, assim como do sucesso registado, as quotas são uma das medidas mais críticas das últimas duas décadas (Krook e Zetterberg 2014), gerando fortes controvérsias sociais (Dahlerup 2008; Maggie e Fry 2002). Não obstante, tal fenómeno tem suscitado interesse, tanto por parte da população em geral, como da academia, conduzindo a 
um amplo debate e crescente desenvolvimento da investigação sobre os seus impactos na educação, na saúde, no mercado de trabalho, na esfera associativa e política a nível nacional e internacional. Compreender as variadas e complexas formas de rejeição às políticas afirmativas em contextos de extrema desigualdade de classe, género, raça, etnia e outros marcadores sociais motiva-nos a propor este Dossiê.

Assim, para colmatar as lacunas existentes na investigação nesta área, este dossiê especial convida a contribuições teóricas, metodológicas e empíricas, com dados nacionais ou internacionais, ou comparativos que se debrucem sobre os seguintes temas:

- Medidas de ação afirmativa numa perspetiva de género, e/ou de raça, e/ou étnica, e/ou de classe, e/ou idade, e/ou orientação sexual, e/ou diversidade funcional;

- Análises de medidas de ação afirmativa centradas no mundo educativo, político, associativo e empresarial, entre outros;

- Abordagens interseccionais em género, raça, classe, e/ou outros marcadores identitários, e medidas de ação afirmativa;

- Mediatização e estratégias de comunicação em torno das medidas de ação afirmativa em diversas esferas;

- Políticas afirmativas, ações políticas e movimentos sociais;

- Entre outras.

\section{Referências}

Akotirene, Carla. 2019. O que é interseccionalidade? São Paulo: Sueli Carneiro; Pólen.

Cerqueira, Carla, e Sara I. Magalhães. 2017. «Ensaio sobre cegueiras: cruzamentos intersecionais e (in) visibilidades nos media.» ex æquo 35, 9-20. https:/ / doi.org/10.22355/ exaequo.2017.35.01

Crenshaw, Kimberle. 1989. «Demarginalizing the intersection of race and sex: A Black feminist critique of antidiscrimination doctrine, feminist theory, and Antiracist Politics.» University of Chicago Legal Forum 14: 57-80.

Collins, Patricia Hill, and Sirma Bilge. 2018. Intersectionality. UK: Polity Press.

Dahlerup, Drude. 2008. «Gender quotas: Controversial but trendy.» International Feminist Journal of Politics 10: 322-328.

Dahlerup, Drude, and Lenita Freidenvall. 2005. «Quotas as a "fast track" to equal representation for women.» International Feminist Journal of Politics 7: 26-48.

Garcia-Filice, Renísia Cristina. 2011. Raça e classe na gestão da educação básica brasileira: a cultura na implementação de políticas públicas. Campinas: Autores Associados.

IPU. 2020. Monthly ranking of women in national parliaments. Disponível em https: / / data.ipu.org/ women-ranking

Krook, Mona Lena, and Pippa Norris. 2014. «Beyond quotas: Strategies to promote gender equality in elected office.» Political Studies 62: 2-20.

Krook, Mona Lena, and Diana O'Brien. 2010. «The politics of group representation: Quotas for women and minorities worldwide.» Comparative Politics 42 (3): 253-272.

Krook, Mona Lena, and Pär Zetterberg. 2014. «Electoral quotas and political representation: Comparative perspectives.» International Political Science Review 35 (1): 3-11.

Maggie, Ivone, e Peter Fry. 2002. «Enfoque». Revista Eletrônica 1: 93-117.

Procacci, Giovanna, et Maria Grazia Rossilli. 1997. «La construction de l'égalité dans l'action des organisations internationales. » In Encyclopédie politique et historique des femmes, organisée par Christine Fauré, 827-859. Paris: PUF. 
Santos, Maria Helena. 2011. Do défice de cidadania à paridade política: Testemunhos de deputadas e deputados. Porto: Edições Afrontamento.

Santos, Maria Helena, e Lígia Amâncio. 2012a. «Resistências à igualdade de género na política.» ex æquo 25: 45-58.

Santos, Maria Helena, e Lígia Amâncio. 2014. «Sobreminorias em profissões marcadas pelo género: consequências e reações.» Análise Social 212: 700-726.

\section{Prazo de envio:}

Envio de artigos, com escrupuloso cumprimento das normas da revista apresentadas em http: / / www.apem-estudos.org/pt/ page/ submissao-de-artigos, até 30 de maio de 2021, para o endereço apem1991@gmail.com. Os textos que não respeitarem as normas quanto à extensão, à formatação e ao modo de citar e referenciar as fontes bibliográficas serão excluídos numa primeira triagem antes de serem submetidos a arbitragem científica. No prazo de quatro semanas após a data limite de receção, as/os autoras/es receberão a informação sobre os resultados da primeira triagem e a passagem à etapa seguinte, isto é, da submissão, sob anonimato, à dupla arbitragem científica do texto. A data prevista de publicação deste número é dezembro de 2021.

\section{Além das submissões para os dossiers temáticos, a ex æquo aceita permanentemente contributos para as secções de Estudos e Ensaios e Recensões.}




\section{ESTATUTO EDITORIAL}

- A ex æquo é uma publicação semestral, fundada pela Associação Portuguesa de Estudos sobre as Mulheres - APEM, com o objetivo de contribuir para o desenvolvimento, visibilização e legitimação do conhecimento produzido no âmbito dos Estudos sobre as Mulheres/Estudos Feministas/Estudos de Género. É um veículo de intercâmbio entre quem faz investigação sob a égide das perspetivas destes estudos, ao nível académico, governamental ou das organizações cívicas e culturais. Assim, destina-se a investigadores/as e a estudantes nestas áreas, procurando dirigir-se também ao público em geral no sentido da sensibilização para estes campos do saber.

- Reconhecendo que os Estudos sobre as Mulheres, do Género e Feministas se têm caracterizado pelo alargamento e entrosamento disciplinar, pela diversidade temática e pela pluralidade de perspetivas teóricas e epistemológicas, a revista assume-se interdisciplinar e multidisciplinar, aberta ao contributo das diversas disciplinas e correntes. Dado que a estrutura matricial da revista é a APEM, é objetivo da ex æquo contribuir para a alteração de práticas e representações estereotipadas e discriminatórias em função do sexo ou de outras pertenças identitárias, adotando, nomeadamente, uma linguagem não discriminatória, inclusiva e promotora da igualdade. No mesmo sentido, as investigações empíricas podem e devem sustentar artigos que incluam uma reflexão teórica e contribuam para a problematização das principais questões que afetam as relações sociais entre mulheres e homens na sociedade. A ex æquo, sem prejuízo da pluralidade e multiplicidade das perspetivas presentes nos textos que publica, reserva-se o direito de só aceitar textos que no respeito pelo princípio de defesa dos Direitos Humanos fundamentais, traduzam a valorização da diversidade da condição humana, bem como da sua integridade e dignidade.

- As áreas de interesse da revista são os Estudos sobre as Mulheres, os Estudos de Género e os Estudos Feministas.

A ex æquo publica trabalhos originais em Português, Espanhol, Francês e Inglês, provenientes de todas as áreas científicas, que se inscrevam no quadro dos Estudos sobre as Mulheres ou dos Estudos de Género ou dos Estudos Feministas. Publica, ainda, recensões sobre obras publicadas nos referidos domínios.

\section{PROCEDIMENTO DE ARBITRAGEM}

- Pareceres por duas pessoas, double blind peer review, especialistas na respetiva área em que o texto se enquadra ou referencia. Os textos são enviados sob anonimato aos/às referees, a quem é solicitado que o parecer emitido tenha em conta, de acordo com a ficha de avaliação: a adequação e enquadramento do artigo nos objetivos da revista $e x æ q u o$; a sua qualidade científica; a pertinência, originalidade, clareza e coerência de conteúdos; a adequação, atualidade e cumprimento das normas consagradas da bibliografia; a pertinência, adequação e explicitação da metodologia e da informação; a clareza da escrita e a coerência e o equilíbrio formais. Os pareceres deverão incluir uma recomendação em relação a possível publicação, entre as seguintes: aceite sem restrições; aceite com restrições (indicando quais); rejeitado. Será ainda solicitada a indicação de sugestões e sua justificação, para melhoria da qualidade científica do artigo submetido a parecer, a ser enviadas, sob anonimato, à(s) pessoa(s) autora(s).

- A revista destina-se a investigadoras/es e a estudantes nas áreas de interesse da revista, procurando também dirigir-se ao público em geral, com vista à sua sensibilização para os mesmos campos do saber. 


\section{NORMAS PARA SUBMISSÃO E AVALIAÇÃO DE ARTIGOS}

Todos os originais devem conter a versão final do texto, pronta a publicar, devidamente revista de gralhas, e, quando incluírem materiais gráficos ou icónicos, estes devem ter uma boa definição, com indicação clara dos locais do texto onde devem ser inseridos.

1. O texto informático (em ficheiro WORD) deve ser enviado por correio eletrónico para apem1991@gmail.com

2. Os artigos não devem exceder 40.000 caracteres, incluindo espaços, notas e referências bibliográficas e excluindo os resumos.

3. As recensões não devem exceder os 10.000 caracteres (espaços incluídos).

4. Cada artigo deve ser acompanhado de um resumo, com o máximo de 750 caracteres, traduzido para três línguas, sendo o português e o inglês OBRIGTÓRIOS, e espanhol ou francês.

5. O título do artigo deve ser traduzido nas mesmas línguas dos resumos.

6. Devem preceder o texto, situando-se após o título, autoria e filiação institucional da(s) autora(s) ou autor(es).

7. A seguir a cada resumo, devem ser indicadas 4 ou 5 palavras-chave, traduzidos nas mesmas línguas dos resumos, apresentadas em minúsculas (com exceção da $1{ }^{a}{ }^{a}$ da lista), separadas por vírgula e terminadas em ponto final.

8. A ex æquo segue a grafia do Novo Acordo Ortográfico da Língua Portuguesa de 1990 - em caso de dúvida consultar: http://www.portaldalinguaportuguesa. org/?action=lince

9. Cada autor/a deve enviar uma breve nota biobibliográfica, que não exceda 500 caracteres, e o endereço postal e eletrónico.

10. Todas as citações devem ser traduzidas para a língua em que o texto é publicado.

11. Todos os originais devem:

a) vir acompanhados de um título abreviado (no máximo 4 palavras), destinado aos cabeçalhos;

b) Para além do endereço de correio eletrónico, deve ser fornecida a filiação institucional das/os autoras/es, cuja identificação deve conter os seguintes elementos:

- Nome por extenso e por sigla da(s) instituição(ões) de pertença (máximo duas);

- Código postal e cidade em que se situa(m);

- Nome do(s) País(es);

- endereço eletrónico de todas as pessoas autoras;

12. Na composição e formatação dos textos devem ser tidas em conta as seguintes orientações:

a) sugere-se a utilização de, no máximo, dois níveis de titulação, sem numeração ou com numeração árabe;

b) as transcrições deverão abrir e fechar com aspas, quando não excederem 40 palavras; no caso de citações mais longas, devem ser entalhadas e transcritas sem aspas e sem itálico;

c) os vocábulos noutras línguas que não aquela em que o artigo está escrito devem ser formatados em itálico;

d) os elementos não textuais devem ser organizados em quadros, gráficos ou figuras, identificados com numeração árabe contínua para cada um destes tipos de elementos; todos devem ter um título e indicada a respetiva fonte;

e) nas chamadas de notas devem utilizar-se apenas números sem parênteses; 
As referências bibliográficas devem ser indicadas entre parênteses no corpo do texto, de acordo com o seguinte padrão: (Leach 1993, 103); (Balibar e Wallerstein 1991, 80-84); (Yuval-Davis 1997a); (Yuval-Davis 1997b).

No texto, quando se citam autores/as diferentes e obras diferentes sobre uma mesma ideia deve respeitar-se a ordem cronológica, elencando as referências da mais antiga para a mais recente (e a ordem alfabética dos Apelidos, quando se trata de obras com a mesma data).

Ex: (Rosende 2002; Miller e Clark 2008; Lo Sasso et al. 2011; Riska 2011)

No final do artigo deve incluir-se a lista de obras citadas, apresentada segundo a norma Chicago (17 ${ }^{\text {a }}$ edição):

Livro com um/a autor/a: Apelido, Nome próprio. Ano. Título do livro (em itálico). (edição) (se for relevante). Local de edição: Editora.

Ex: Lamas, Maria. 1948. As Mulheres do Meu País. Lisboa: Actuália Lda.

Livro com duas/ois ou três autoras/es: Apelido, Nome próprio, Nome próprio Apelido, Nome próprio Apelido, e Nome próprio Apelido. Ano. Título do livro (em itálico). (edição) (se for relevante). Local de edição: editora.

Ex: Pimentel, Irene Flunser e Helena Pereira de Melo. 2015. Mulheres Portuguesas História da vida e dos direitos das mulheres num mundo em mudança. Lisboa: Clube do Autor.

Livro com quatro ou mais autoras/es: Apelido, Nome próprio (da/o 1. a ${ }^{\circ}$ ) et al. Ano. Título do livro (em itálico). (edição) (se for relevante). Local de edição: editora.

Capítulo ou parte de livro - Apelido, Nome próprio. Ano. «Título do capítulo.» In Título do livro (em itálico), editado (ou organizado) por Nome Próprio Nome de Família, Nome Próprio Nome de Família, e Nome Próprio Nome de Família, número das páginas. Local de edição: editora.

Ex: Piscitelli, Adriana. 2009. «Gênero: a história de um conceito.» In Diferenças, igualdade, organizado por Heloísa Buarque de Almeida e José Szwako, 116-149. São Paulo: Berlendis \& Vertecchia.

Artigo de revista: Apelido, Nome próprio. Ano. «Título do artigo entre aspas.» Título da revista (em itálico) volume (número): números das páginas apresentados com travessão.

Ex: Guimarães, Elina.1986. «A mulher portuguesa na legislação civil.» Análise Social XXII (92-93): 557-577.

Ou no caso de indicação de volume e número da revista e no caso de o artigo ter DOI, a referência deve ser assim apresentada:

Crenshaw, Kimberle. 1993. «Mapping the margins: Intersectionality, identity politics, and violence against women of color». Stanford Law Review 43 (6): 1241-1299. DOI: https:// doi.org/10.2307/1229039

Artigo com duas/ois ou três autoras/es: Apelido, Nome próprio, Nome próprio Apelido, Nome próprio Apelido, e Nome próprio Apelido. Ano. «Título do artigo entre aspas.» Título da revista (em itálico) volume (número): números das páginas unidos por travessão.

Sempre que a publicação tenha associado um DOI, este deve ser impreterivelmente incluído nas referências bibliográficas, como no exemplo acima. 
- Documento na Internet: Apelido, nome próprio. Ano. Título do documento. Disponível no endereço ... [Consultado em ...... (data segundo a fórmula dia de mês de ano)]

- Publicações em revistas na Internet: Apelido, Nome próprio. Ano. «Título do Artigo (entre aspas)». Título da Revista (em itálico) volume (número): números das páginas unidos por travessão. Disponível em .... Acrescente o DOI (se não estiver disponível, acrescente o URL).

- Locais na Internet e páginas pessoais ou de instituições sem data: Nome. Título do Documento. Disponível em ..... . [Consultado em ...... (data segundo a fórmula dia de mês de ano)].

Em caso de dúvidas ou para outro tipo de referências, consultar: http://www.chicagomanualofstyle.org/tools_citationguide/citation-guide-2.html

NOTA: ANTES DE SEREM ENVIADOS PARA A ARBITRAGEM CIENTÍFICA, OS TEXTOS SÃO OBJETO DE UMA PRIMEIRA TRIAGEM PARA VERIFICAÇÃO DE QUE CUMPREM TODAS AS REGRAS AQUI APRESENTADAS 


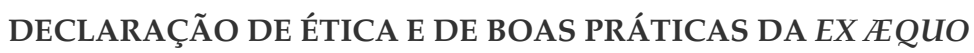

A Revista ex æquo é uma revista com arbitragem científica, interdisciplinar e multidisciplinar, aberta ao contributo das diversas disciplinas e correntes. A ex æquo, sem prejuízo da pluralidade e multiplicidade das perspetivas presentes nos textos que publica, reserva-se $o$ direito de só aceitar textos que respeitem os Direitos Humanos fundamentais, traduzam a valorização da diversidade da condição humana, bem como da sua integridade e dignidade.

A ex æquo é uma publicação da Associação Portuguesa de Estudos sobre as Mulheres (APEM) estando por conseguinte vinculada à sua missão de apoiar, promover e dinamizar os Estudos sobre as Mulheres / Estudos de Género / Estudos Feministas em todas as áreas do saber.

Na Revista ex æquo são defendidos os princípios da declaração de ética e de boas práticas na publicação de acordo com o Código de Conduta e Normas de Boas Práticas para Editores de Revistas do Comité sobre Ética na Publicação - COPE (disponível em http:// publicationethics.org/).

\section{RESPONSABILIDADES DA EQUIPA EDITORIAL (EDITORAS e EDITORAS DE SECÇÕES)}

Decidir quais os artigos submetidos à revista que devem ser publicados. Esta decisão é orientada pelas normas da revista (Normas para apresentação e publicação de textos da ex æquo, disponíveis em http://www.apem-estudos.org/pt/page/submissao-de-artigos) e pelos requisitos legais em matéria de difamação, violações de direitos de autoria e plágio;

Orientar a/o(s) organizador/a(s) convidada/o(s), autor/a(s) e avaliador/a(s) sobre o seu papel, bem como esclarecer sobre o processo de arbitragem científica por pares;

Informar os novos elementos do corpo editorial sobre as suas funções, práticas em vigor e projetos em lançamento;

Avaliar os artigos exclusivamente com base no seu mérito científico e intelectual, independentemente de fatores como: raça, idade, sexo, orientação sexual, deficiência, origem étnica, crença religiosa, nacionalidade, orientação política ou classe social da/o(s) autor/a(s);

Assegurar que o processo de arbitragem científica dos artigos é anónimo (double-blind peer review), justo, rigoroso e isento e que toda a informação a eles relativa permanece confidencial. Assegurar, ao mesmo tempo a proteção da identidade das autoras e dos autores e das avaliadoras e avaliadores;

Constituir e manter uma base de dados de avaliadoras/es pertinentes nas diferentes áreas disciplinares, sempre atualizada;

Garantir uma seleção adequada das avaliadoras/es em cada nova edição da revista;

Garantir que os materiais não publicados não são utilizados na investigação realizada por membros do Corpo Editorial sem consentimento expresso por escrito da(s) autora(s) ou autor(es);

Responder atempadamente a eventuais reclamações apresentadas sobre um artigo submetido ou publicado. Perante suspeita de má conduta, seguir os fluxogramas do COPE, disponíveis em http://publicationethics.org/files/Full\%20set $\% 20$ of $\% 20$ flowcharts.pdf;

Publicar correções, esclarecimentos, retratações e pedidos de desculpa sempre que necessário. 


\section{Boas práticas a observar pela equipa editorial}

Auscultar a visão de autoras/es, leitoras/es, avaliadoras/es, revisoras/es e membros do corpo editorial sobre a forma de melhorar a revista ex æquo.

Encorajar e estar consciente da investigação levada a cabo pela revisão por pares e publicar e reavaliar os processos da ex $\mathfrak{x} q u o$ à luz de novas investigações.

Apoiar iniciativas para informar e sensibilizar as/os investigadoras/es sobre as regras de ética da ex æquo.

Avaliar os efeitos das suas políticas editoriais sobre autoras e autores e avaliadoras/es, incentivando um comportamento responsável e desencorajando as más condutas.

Garantir que todos os relatórios de investigação e revisão de investigação foram revistos por avaliadoras/es com a devida qualificação (incluindo análise estatística quando apropriado), capazes de julgar os textos propostos e livres de desqualificar interesses concorrentes.

Respeitar os pedidos de autoras/es para excluir alguém de rever os textos submetidos, se estes forem bem fundamentados.

Incentivar avaliadoras/es a fazer comentários sobre a originalidade do manuscrito e estar alerta para publicações redundantes e plágio e tomar medidas para garantir um elevado nível de qualidade.

\section{RESPONSABILIDADES DO CONSELHO CIENTÍFICO}

Apoiar o Conselho de Redação na interpretação e orientação da política editorial da revista;

Assegurar a arbitragem de propostas de artigos desde que inseridos nas respetivas áreas de especialização;

Estabelecer a ligação a potenciais avaliadoras/es [referees] para o processo de arbitragem científica e em situações em que as propostas originaram pareceres antagónicos ou outro tipo de dúvidas, analisar pareceres e, com base neles, recomendar a rejeição ou publicação de originais;

Divulgar os apelos a contributos na sua rede de contactos;

Contribuir para a divulgação da revista ex æquo;

Participar em reuniões da Comissão Científica que eventualmente venham a ser convocadas.

\section{RESPONSIBILIDADES DE QUEM FAZ A AVALIAÇÃO [peer review]}

\section{Contribuição para a decisão editorial}

A revisão por pares ajuda a equipa editorial na decisão e pode também contribuir para a melhoria do manuscrito submetido.

\section{Prontidão}

Cada avaliador/a convidada/o que considere não possuir a qualificação para avaliar o manuscrito submetido ou que anteveja a impossibilidade de comunicar a sua avaliação em tempo oportuno deverá informar de imediato a equipa editorial ou a pessoa que fez o convite para que possam ser encontradas alternativas em tempo útil. 


\section{Confidencialidade}

Quaisquer trabalhos recebidos para avaliação devem ser tratados como documentos confidenciais. Não devem ser mostrados ou discutidos com outras pessoas, exceto se for autorizado pela equipa editorial.

Padrões de objetividade

Os comentários devem ser apresentados de forma objetiva. Críticas pessoais são inaceitáveis. As opiniões devem ser claras com argumentos justificativos adequados.

Conhecimento das fontes

Devem identificar obras publicadas relevantes e que não tenham sido citadas. E devem, também, chamar a atenção da equipa editorial para qualquer semelhança substancial ou sobreposição entre o manuscrito em questão e quaisquer outras informações ou publicações sobre as quais tenham conhecimento pessoal.

\section{Conflito de interesses}

Informações privilegiadas ou ideias obtidas através da avaliação por pares devem ser mantidas confidenciais e não usadas para vantagem pessoal. Quem avalia não deve aceitar participar quando existe conflitos de interesse resultantes da concorrência, colaboração, ou outros relacionamentos ou ligações com as/os autoras/es, empresas ou instituições ligadas à submissão.

\section{RESPONSABILIDADES DO/A AUTOR/A}

Autoria do manuscrito

A autoria diz respeito a quem fez contribuições significativas para o estudo. Todas as pessoas que contribuíram significativamente devem ser listadas como co-autoras. Outras que tenham participado em certos aspetos substantivos do projeto de pesquisa devem ser listadas nos agradecimentos ou contributos. Cara autora e/ou autor deve garantir que toda a co-autoria devida está incluída no manuscrito, e que viu e aprovou a versão final do documento e concordou com a sua apresentação para publicação.

\section{Padrões de apresentação}

Os resultados de pesquisas originais devem ser acompanhados da apresentação clara e precisa do trabalho realizado, bem como de uma análise objetiva do seu significado. Um documento deve conter detalhes e referências suficientes para permitir que outras pessoas possam replicar o trabalho. Declarações fraudulentas ou intencionalmente imprecisas são inaceitáveis. As regras da revista devem ser escrupulosamente observadas.

\section{Originalidade e plágio}

Cada autora e cada autor deve garantir que escreveu obras inteiramente originais, devendo o trabalho e/ou as palavras de outras autores e autores ser objeto da devida citação ou referência.

\section{Declarações e conflito de interesses}

Cada autora e cada autor deve divulgar no manuscrito qualquer contradição significativa financeira ou outra de interesse que possa ser interpretada no sentido de influenciar os resultados ou a sua interpretação no manuscrito. Todas as fontes de apoio financeiro para o projeto devem ser divulgadas. 
Publicação múltipla, redundante ou concorrente

É considerado um comportamento não ético de publicação descrever a mesma pesquisa em vários artigos e submeter o mesmo artigo a mais de uma revista.

Erros fundamentais em obras publicadas

Quando um/a autor/a descobre um erro significativo ou imprecisão no manuscrito submetido, deve notificar imediatamente a equipa editorial.

\section{Remoção}

Os artigos publicados serão removidos se avaliadoras/es, leitoras/es, bibliotecárias/ os, equipa editorial ou outras entidades detetarem erros significativos ou plágio. Antes de retirar um artigo, o conselho editorial contactará de imediato as/os respetivas/os autoras/es, estabelecendo um prazo suficiente para obter as explicações devidas. Se for decidido que o artigo deve ser retirado então ele deve sair de imediato das bases de dados em linha onde esteja, incluindo o website da APEM, e na versão impressa deve ser referida a sua retirada no número seguinte de forma visível.

\section{RESPONSABILIDADES DA EMPRESA EDITORA}

\section{Autonomia editorial}

A Empresa Editora garante a autonomia de decisões editoriais, sem influência de anunciantes ou de outros parceiros comerciais.

\section{Propriedade intelectual e direitos autorais}

AEmpresa Editora protege a propriedade intelectual e direitos de autoria, o material impresso, autoras/es e parceiros de publicação promovendo e mantendo o registo de cada versão publicada. Defende a transparência de cada artigo publicado no que diz respeito a: conflitos de interesse, de publicação e de financiamento da investigação, de publicação e de ética em investigação, má conduta de publicação e investigação, confidencialidade, autoria, correções do artigo, esclarecimentos, e publicação atempada de conteúdo.

\section{Má conduta científica}

Em casos de alegada ou provada má conduta científica, publicação fraudulenta, a entidade responsável pela publicação em estreita colaboração com a equipa editorial, tomará todas as medidas adequadas para esclarecer a situação e para alterar o artigo em questão. Isso inclui a publicação rápida de um comunicado, correção ou errata ou, nos casos mais graves, a retração da obra afetada. 


\section{CONSELHO CIENTÍFICO/SCIENTIFIC BOARD}

Louise ACKERS (U. Salford, UK)

Tindara ADDABBO (U. Modena e Reggio Emilia, ITA)

Teresa ALVAREZ (U. Aberta, PRT)

Lígia AMÂNCIO (ISCTE - IUL, PRT)

Ana Luísa AMARAL (U. Porto, PRT)

Helena Costa ARAÚJO (U. Porto, PRT)

Madeleine ARNOT (U. Cambridge, UK)

Adriana BEBIANO (U. Coimbra, PRT)

Chiara BERTONE (Inst. Piemonte Orientale 'Amedeo Avogadro', ITA)

Josefina BIRULES BERTRAN (U. Autònoma Barcelona, ESP)

Gisela BOCK (Freie Universität Berlin, DEU)

Carolyn BYERLY (Howard U., USA)

Erica BURMAN (U. Manchester, UK)

Rosa CABECINHAS (U. Minho, PRT)

Pat CARLEN (U. Leicester, UK)

Nuno CARNEIRO (U. Porto/U. Complutense Madrid, ESP)

Sara Falcão CASACA (U. Lisboa, PRT)

Fernando CASCAIS (U. Nova Lisboa, PRT)

Richard CLEMINSON (U. Leeds, UK)

Zowie DAVY (U. Lincoln, UK)

Jonathan DEAN (U. Leeds, UK)

Maria Angeles DURAN (Higher Council for Scientific Research, ESP)

Antonia FERNANDEZ VALENCIA

(U. Complutense Madrid, ESP)

Juana GALLEGO (U. Autònoma Barcelona, ESP)

Silvana Vilodre GOELLNER (U. Federal do

Rio Grande do Sul, BRA)

Jack HALBERSTAM (U. Southern California, USA)

Jeff HEARN (U. Örebro, SWE)

Tone HELLESUND (U. Bergen, NOR)

Fernanda HENRIQUES (U. Évora, PRT)

María Jesús IZQUIERDO (U. Autònoma Barcelona, ESP)

Elisa JATO (U. Santiago Compostela, ESP)

Celia JENKINS (U. Westminster, UK)

Jane JENSON (U. Montreal, CAN)

Teresa JOAQUIM (U. Aberta, PRT)

Maria KARAMESSINI (Panteion U. Social and Political Sciences, GRC)
Maria José MAGALHÃES (U. Porto, PRT)

Barbara MERRILL (U. Warwick, UK)

Sofia NEVES (Instituto Universitário da Maia, PRT)

Áine Ní LÉIME (National U. Ireland, IRL)

Conceição NOGUEIRA (U. Porto, PRT)

Karen OFFEN (U. Stanford, USA)

João Manuel de OLIVEIRA (Inst.

Universitário de Lisboa, PRT)

Joanna OSTROUCH-KAMIŃSKA

(U. Warmińsko-Mazurski Olsztynie, POL)

Heloísa PERISTA (Centro Estudos para Intervenção Social, PRT)

Teresa PINTO (U. Aberta, PRT)

Vânia C. PINTO (Universidade de Brasília, BRA)

Adriana PISCITELLI (U. Estadual Campinas, BRA)

Lucas PLATERO (U. Rey Juan Carlos, ESP)

Sílvia PORTUGAL (U. Coimbra, PRT),

Marco Aurélio PRADO (U. Federal Minas Gerais, BRA)

Alicia PULEO (U. Valladolid, ESP)

Rebecca ROGERS (U. Paris-Descartes, FRA)

Karen ROSS (U. Northumbria, UK),

Jill RUBERY (U. Manchester, UK)

Ana Cristina SANTOS (U. Coimbra, PRT)

Gina dos SANTOS (U. Minho, PRT)

Joan W. SCOTT (Institute for Advanced Study - Princeton, USA)

Lynne SEGAL (U. London, UK)

Paula SILVA (U. Porto, PRT)

Teresa TAVARES (U. Coimbra, PRT)

Filomena TEIXEIRA (Inst. Politécnico Coimbra, PRT)

Teresa TOLDY (U. Fernando Pessoa, PRT)

Juracy TONELI (U. Federal Santa Catarina, BRA)

Anália TORRES (U. Técnica Lisboa, PRT)

Miguel VALE DE ALMEIDA (ISCTE - IUL, PRT)

Paola VILLA (U. Trento, ITA)

Karin WALL (U. Lisboa, PRT)

Claire WALLACE (U. Aberdeen, UK)

Michelle ZANCARINI-FOURNEL (U. Lyon-1, FRA) 



\section{PROPOSTA DE ASSINATURA}

Se deseja assinar a ex æquo recorte este talão e envie-o, devidamente preenchido, para edições afrontamento,

Rua de Costa Cabral, 859 - 4200-225 Porto

$\square$ Assino a revista ex æquo

$$
\text { (n. } \left.{ }^{\circ} 40,41\right)
$$

Continente $\quad 35 € \square$

Regiões autónomas $40 € \square$

Europa $\quad 55 € \square$

Extra-Europa $\quad 60 € \square$

[Estes preços incluem IVA à taxa de 5\% e portes]

\section{Pagamento}

Junto envio o cheque . $^{\circ}$ à ordem de

Edições Afrontamento, no valor de

Número de identificação fiscal

Assinatura

Nome:

Morada:

Tel: Fax:

E-mail

Visite o sítio na internet das Edições Afrontamento em www.edicoesafrontamento.pt 


SITUACIONISMO DE SEXO: UM DIAGNÓSTICO FEMINISTA À PLATAFORMA DE PEQUIM PASSADOS 25 ANOS. Cláudia Álvares, Maria João Silveirinha e Virgínia Ferreira

«ESTUDOS SOBRE AS MULHERES» EM PORTUGAL PÓS-DECLARAÇÃO DE PEQUIM - ESTUDO BIBLIOMÉTRICO DAS REVISTAS EX AEQUO E FACES DE EVA. Virgínia Ferreira, Cristina C. Vieira, Maria João Silveirinha, Elizângela Carvalho e Priscila Freire

DREAMING THE WELFARE-STATE: INDIAN WOMEN-STUDIES-MOVEMENT, NEOLIBERALISM AND FEMINIST FUTURE. Cheshta Arora

FEMINISM AND/IN THE/ITS PLURAL. Begonya Saez Tajafuerce

ACADEMIAS DE TALENTO FEMININO: MEIOS DE EMANCIPAÇÃO OU FERRAMENTAS DE REPRODUÇÃO SOCIAL? Susana Santos

FAZER O MESMO, SEM SER O MESMO: FEMINILIDADES, NEOLIBERALISMO EANTIFEMINISMO NO CONTEXTO GODLLYWOOD BRASIL. Monise Martinez

SURFANDO NA ONDA DIGITAL: FEMINISMOS EM REDE NO BRASIL. Raquel de Barros Pinto Miguel, Djenifer Samantha Marx e Gilmara Joanol Arndt e Soraia Lobo

PÓS-FEMINISMO, PÓS-RACIALISMO E PÓS-COLONIALISMO: A COBERTURA MEDIÁTICA DA CAMPANHA DE JOACINE KATAR MOREIRA. Rita Basílio de Simões e Inês Amaral

ESTUDOS E ENSAIOS

A IGUALDADE DE GÉNERO NAS ORGANIZAÇÕES E O EFEITO DO RECONHECIMENTO PÚBLICO: O CASO DO PRÉMIO IGUALDADE É QUALIDADE . Mariana Pinheiro e Sara Falcão Casaca

ARCHITECT LUZ VALENTE-PEREIRA: ARCHITECTURE, RESEARCH, AND LIFE IN A CHANGING COUNTRY. Patrícia Santos Pedrosa e Lia Gil Antunes

\section{RECENSÕES}

Gender Studies and the New Academic Governance. Global Challenges, Glocal Dynamics and Local Impacts, edited by Heike Kahlert. Wiesbaden, Springer, 2018, 289 pp. Júlia Garraio

$15 €$

PUBLICAÇÃO SEMESTRAL

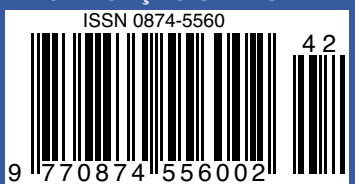

The Positioning and Making of Female Professors. Pushing Career Advancement Open, edited by Rowena Murray \& Denise Mifsud. Palgrave Studies in Gender and Education. Palgrave Macmillan, 2019, 241 pp. Sofia Castanheira Pais

Revolución feminista y políticas de lo común frente a la extrema derecha, edited by María Eugenia Rodríguez Palop. Barcelona: Icaria, 2019, 151 pp. Jana Soler Libran

Cuidar de quem cuida: histórias e testemunhos de um trabalho invisível. Um manifesto para o futuro, de José Soeiro, Mafalda Araújo e Sofia Figueiredo. Objectiva, Penguim Random House: Lisboa, 2020, 239 pp. Manuel Abrantes

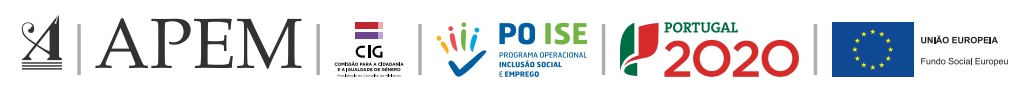

